\title{
Identification of RESNET HERS Index Values Corresponding to Minimal Compliance with the IECC Performance Path
}

Z Todd Taylor

Vrushali Mendon

May 2014

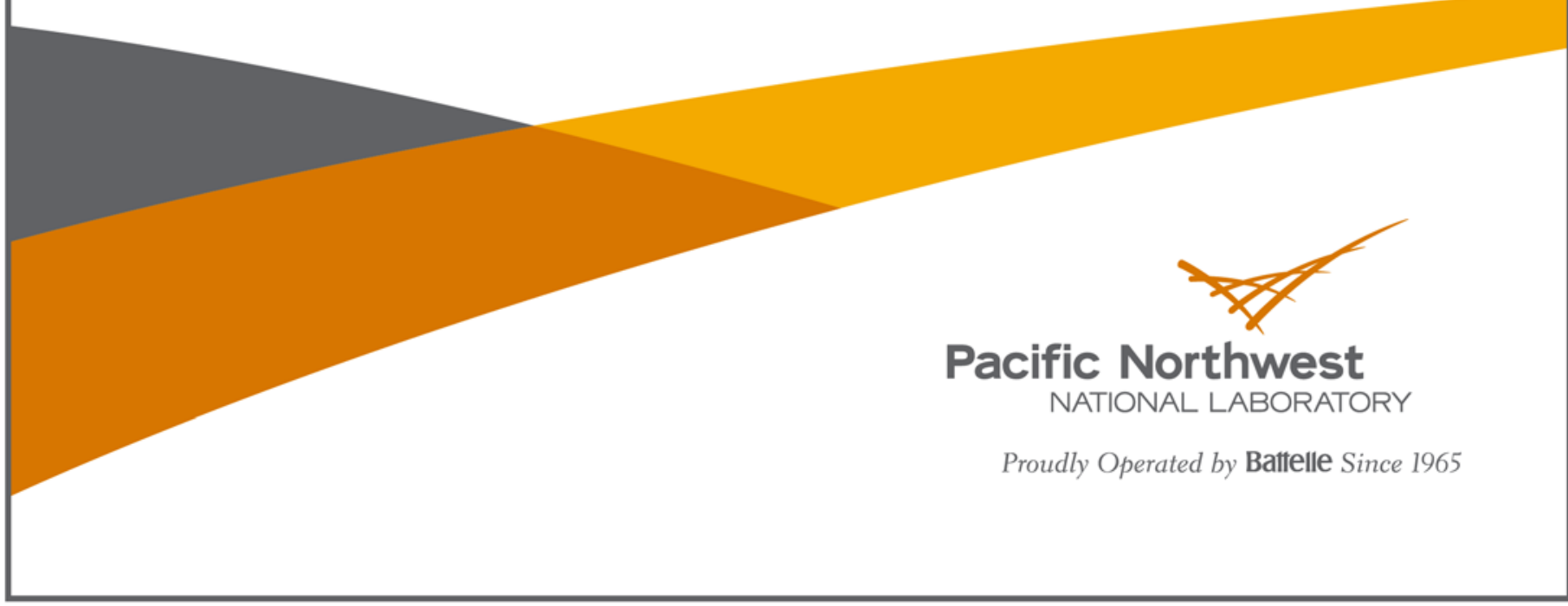




\title{
DISCLAIMER
}

This report was prepared as an account of work sponsored by an agency of the United States Government. Neither the United States Government nor any agency thereof, nor Battelle Memorial Institute, nor any of their employees, makes any warranty, express or implied, or assumes any legal liability or responsibility for the accuracy, completeness, or usefulness of any information, apparatus, product, or process disclosed, or represents that its use would not infringe privately owned rights. Reference herein to any specific commercial product, process, or service by trade name, trademark, manufacturer, or otherwise does not necessarily constitute or imply its endorsement, recommendation, or favoring by the United States Government or any agency thereof, or Battelle Memorial Institute. The views and opinions of authors expressed herein do not necessarily state or reflect those of the United States Government or any agency thereof.

\author{
PACIFIC NORTHWEST NATIONAL LABORATORY \\ operated by \\ BATTELLE \\ for the \\ UNITED STATES DEPARTMENT OF ENERGY \\ under Contract DE-AC05-76RL01830
}

Printed in the United States of America
Available to DOE and DOE contractors from the Office of Scientific and Technical Information,
P.O. Box 62, Oak Ridge, TN 37831-0062;
ph: (865) 576-8401
fax: $(865) 576-5728$
email: reports@adonis.osti.gov
Available to the public from the National Technical Information Service
5301 Shawnee Rd., Alexandria, VA 22312 ph: (800) 553-NTIS (6847)
email: orders@ntis.gov $<$ http://www.ntis.gov/about/form.aspx $>$
Online ordering: http://www.ntis.gov

This document was printed on recycled paper. 


\title{
Identification of RESNET HERS Index Values Corresponding to Minimal Compliance with the IECC Performance Path
}

\author{
Z Todd Taylor \\ Vrushali Mendon
}

May 2014

Prepared for

the U.S. Department of Energy

under Contract DE-AC05-76RL01830

Pacific Northwest National Laboratory

Richland, Washington 99352 


\section{Summary}

This analysis provides a limited evaluation of the relationship between the Residential Energy Services Network (RESNET) Home Energy Rating System (HERS) Index and the simulation-based Performance Path used in the International Energy Conservation Code (IECC). Not all differences between the approaches are analyzed in this report; only a subset of building characteristics considered likely to result in quantifiable differences in the outcomes of the two approaches or otherwise believed to be of interest to code developers and policy makers are considered. This analysis evaluates, for a single-family residence with various characteristics, the ranges of HERS Index values that would imply compliance with the 2012 IECC's Performance Path. The characteristics considered are as follows:

- HVAC equipment type and efficiency

- conditioned floor area (CFA)

- window-floor ratio (WFR)

- appliance efficiency

- foundation type

- number of stories

- glazing distribution/orientation.

While the IECC is defined primarily by prescriptive provisions, the code also allows compliance through a performance-based approach that compares the energy performance of a proposed home to that of a similar home - called the Standard Reference Design (SRD) — configured to meet the code's prescriptive requirements. The proposed new home or renovation, by comparison, is referred to as the Proposed Design. Compliance with the IECC using the Performance Path is based on the Proposed Design's annual energy cost compared to that of the SRD. Similarly, the HERS Index rates an analyzed home (known as the Rated Home) based on its energy performance relative to a defined reference home-called the HERS Reference Home- of similar size and configuration. Calculation of the HERS Index is based on a specialized metric known as the normalized Modified End-Use Load (nMEUL). This analysis compares the two approaches in characterizing a candidate home's energy performance to provide information about HERS Index values that correspond to compliance with the 2012 IECC’s Performance Path.

Because the 2015 IECC was not yet available at the time this analysis was conducted, the analysis was based on the 2012 IECC. However, the comparisons in this report apply equally to the 2015 IECC because neither the prescriptive code requirements that affect the parameters and methodology of this study nor the Performance Path has changed substantially in the 2015 IECC. ${ }^{1}$ One notable change that is relevant to this study is the 2015 IECC's addition of a new compliance path based on an Energy Rating Index (ERI). The ERI is defined such that RESNET's HERS is a candidate system for demonstrating compliance. Although the specific ERI thresholds defined in the 2015 IECC are not the focus of this study, a similarity is noted between those thresholds and the results of this study.

\footnotetext{
${ }^{1}$ This is based on the published final actions of the 2015 ICC Public Comment Hearing held in October 2013.
} 
In order to evaluate the correlation between the HERS rule set and the IECC Performance Path, energy analyses are carried out using the single-family prototype developed by PNNL to support the U.S. Department of Energy for its energy and economic analyses of residential energy codes (Taylor et al. 2012; Mendon et al. 2013). These prototype building models cover a range of building characteristics in 15 climate locations and can be freely downloaded from http://www.energycodes.gov/development/residential/iecc_models.

The results of this analysis indicate that the relationship between HERS Index values and IECC compliance is complex and difficult to generalize for any one home demographic. It is clear, however, that equipment efficiency, house size, and high-efficiency home appliances are the most significant characteristics in explaining differences in how HERS-based compliance would differ from compliance via the IECC Performance Path. Depending on the climate zone, other home characteristics may be impactful as well. The relationship between HERS Index values and IECC compliance is described using "Corresponding HERS Index” values, which are HERS Index values that correspond to minimal IECC compliance for homes with a wide variety of characteristics.

Table S.1 summarizes the overall Corresponding HERS Index ranges resulting from this analysis. For each climate zone, the full range of Corresponding HERS Indexes is shown along with a worst-case range after accounting for the most significant home characteristics analyzed. For some climate zones, more than one combination of home characteristics resulted in the same magnitude of the Corresponding HERS Index range. In such cases, the most conservative HERS Index range (the one with the lower absolute Index values) was chosen to be included in the table. HERS Index ranges for three HVAC scenarios are shown: 1) the baseline runs with federal minimum equipment efficiencies, 2) the high-AFUE (annual fuel utilization efficiency) gas furnace scenario run for the climate zone, and 3) the high-efficiency heat pump scenario run for the climate zone. For the variety of home characteristics analyzed here, the following are observed:

- When no building characteristics are accounted for, the range of Corresponding HERS Indexes spans 19 to 26 points, depending on climate zone. This finding is significant, suggesting that two homes that minimally comply with the 2012 (or 2015) IECC Performance Path can have HERS Index ratings that differ by as much as 26 points, which ostensibly represents a $26 \%$ difference in energy performance.

- When the most significant building characteristics are accounted for, the range of Corresponding HERS Indexes spans 5 to 11 points, depending on climate zone.

- The most efficient HVAC options lower the Corresponding HERS Index by 4 to 10 points compared to the case of federal minimum efficiencies, depending on climate zone.

- It is noted that the lowest Corresponding HERS Index values calculated in this analysis are very similar to the ERI thresholds in the 2015 IECC's new ratings-based compliance path. This is a significant finding because RESNET's HERS appears to be a likely rating system to be used as an ERI for that code. 
Table S.1. Volatility of Corresponding HERS Indexes

\begin{tabular}{|c|c|c|c|c|c|c|c|}
\hline \multirow{2}{*}{$\begin{array}{l}\text { Climate } \\
\text { Zone \& } \\
\text { Moisture } \\
\text { Regime } \\
\end{array}$} & \multirow[b]{2}{*}{$\begin{array}{c}\text { HVAC Type \& } \\
\text { Efficiency }^{3}\end{array}$} & \multicolumn{3}{|c|}{$\begin{array}{l}\text { Full range of } \mathrm{CHI}^{1} \text { before } \\
\text { accounting for any of the } \\
\text { home characteristics ana- } \\
\text { lyzed in this study }\end{array}$} & \multicolumn{3}{|c|}{$\begin{array}{c}\text { Worst-case (largest) range } \\
\text { of CHI after accounting for } \\
\text { the most significant home } \\
\text { characteristics analyzed in } \\
\text { this study }{ }^{2}\end{array}$} \\
\hline & & $\begin{array}{r}\text { Lowest } \\
\text { CHI }\end{array}$ & $\begin{array}{l}\text { Highest } \\
\text { CHI }\end{array}$ & Span & $\begin{array}{r}\text { Lowest } \\
\text { CHI }\end{array}$ & $\begin{array}{l}\text { Highest } \\
\text { CHI }\end{array}$ & Span \\
\hline \multirow{3}{*}{$\begin{array}{l}\text { Zone 1, } \\
\text { Moist }\end{array}$} & Base HVAC \& Base HP & 57 & 82 & \multirow{3}{*}{25} & 57 & 68 & \multirow{3}{*}{11} \\
\hline & SEER 20-AFUE 80 & 47 & 72 & & 47 & 58 & \\
\hline & SEER 15-HSPF 8.2 & 53 & 78 & & 53 & 64 & \\
\hline \multirow{3}{*}{$\begin{array}{l}\text { Zone 2, } \\
\text { Moist }\end{array}$} & Base HVAC \& Base HP & 62 & 83 & \multirow{3}{*}{21} & 62 & 68 & \multirow{3}{*}{6} \\
\hline & SEER 20-AFUE 80 & 54 & 75 & & 54 & 60 & \\
\hline & SEER 15-HSPF 8.2 & 59 & 80 & & 59 & 65 & \\
\hline \multirow{3}{*}{$\begin{array}{l}\text { Zone 2, } \\
\text { Dry }\end{array}$} & Base HVAC \& Base HP & 59 & 80 & \multirow{3}{*}{21} & 59 & 66 & \multirow{3}{*}{7} \\
\hline & SEER 20-AFUE 80 & 49 & 70 & & 49 & 56 & \\
\hline & SEER 15-HSPF 8.2 & 54 & 75 & & 54 & 61 & \\
\hline \multirow{3}{*}{$\begin{array}{l}\text { Zone 3, } \\
\text { Moist }\end{array}$} & Base HVAC \& Base HP & 55 & 77 & \multirow{3}{*}{22} & 55 & 61 & \multirow{3}{*}{6} \\
\hline & SEER 20-AFUE 96 & 47 & 69 & & 47 & 53 & \\
\hline & SEER 15-HSPF 9.0 & 52 & 74 & & 52 & 58 & \\
\hline \multirow{3}{*}{$\begin{array}{l}\text { Zone 3, } \\
\text { Dry }\end{array}$} & Base HVAC \& Base HP & 58 & 77 & \multirow{3}{*}{19} & 58 & 63 & \multirow{3}{*}{5} \\
\hline & SEER 20-AFUE 96 & 50 & 69 & & 50 & 55 & \\
\hline & SEER 15-HSPF 9.0 & 54 & 73 & & 54 & 59 & \\
\hline \multirow{3}{*}{$\begin{array}{l}\text { Zone 3, } \\
\text { Marine }\end{array}$} & Base HVAC \& Base HP & 56 & 82 & \multirow{3}{*}{26} & 60 & 68 & \multirow{3}{*}{8} \\
\hline & SEER 20-AFUE 96 & 52 & 78 & & 56 & 64 & \\
\hline & SEER 15-HSPF 9.0 & 55 & 81 & & 59 & 67 & \\
\hline \multirow{3}{*}{$\begin{array}{l}\text { Zone 4, } \\
\text { Moist }\end{array}$} & Base HVAC \& Base HP & 56 & 79 & \multirow{3}{*}{23} & 56 & 64 & \multirow{3}{*}{8} \\
\hline & SEER 20-AFUE 96 & 48 & 71 & & 48 & 56 & \\
\hline & SEER 15-HSPF 9.0 & 53 & 76 & & 53 & 61 & \\
\hline \multirow{3}{*}{$\begin{array}{l}\text { Zone 4, } \\
\text { Dry }\end{array}$} & Base HVAC \& Base HP & 56 & 77 & \multirow{3}{*}{21} & 56 & 63 & \multirow{3}{*}{7} \\
\hline & SEER 20-AFUE 96 & 48 & 69 & & 48 & 55 & \\
\hline & SEER 15-HSPF 9.0 & 53 & 74 & & 53 & 60 & \\
\hline \multirow{3}{*}{$\begin{array}{l}\text { Zone 4, } \\
\text { Marine }\end{array}$} & Base HVAC \& Base HP & 58 & 82 & \multirow{3}{*}{24} & 60 & 68 & \multirow{3}{*}{8} \\
\hline & SEER 20-AFUE 96 & 54 & 78 & & 56 & 64 & \\
\hline & SEER 15-HSPF 9.0 & 56 & 80 & & 58 & 66 & \\
\hline
\end{tabular}

\footnotetext{
${ }^{1}$ Corresponding HERS Index.

${ }^{2}$ In most scenarios, the home size and type of appliances used were the most significant characteristics. However, these varied by climate zone.

${ }^{3}$ HVAC efficiencies shown in the table include a Federal minimum set and the highest gas furnace and heat pump efficiencies analyzed.
} 
Table S.1. (continued)

\begin{tabular}{|c|c|c|c|c|c|c|c|}
\hline \multirow{2}{*}{$\begin{array}{l}\text { Climate } \\
\text { Zone \& } \\
\text { Moisture } \\
\text { Regime }\end{array}$} & \multirow[b]{2}{*}{$\begin{array}{c}\text { HVAC Type \& } \\
\text { Efficiency }^{3}\end{array}$} & \multicolumn{3}{|c|}{$\begin{array}{l}\text { Full range of } \mathrm{CHI}^{1} \text { before } \\
\text { accounting for any of the } \\
\text { home characteristics ana- } \\
\text { lyzed in this study }\end{array}$} & \multicolumn{3}{|c|}{$\begin{array}{l}\text { Worst-case (largest) range } \\
\text { of CHI after accounting for } \\
\text { the most significant home } \\
\text { characteristics analyzed in } \\
\text { this study }{ }^{2}\end{array}$} \\
\hline & & $\begin{array}{r}\text { Lowest } \\
\text { CHI }\end{array}$ & $\begin{array}{l}\text { Highest } \\
\text { CHI }\end{array}$ & Span & $\begin{array}{r}\text { Lowest } \\
\text { CHI }\end{array}$ & $\begin{array}{l}\text { Highest } \\
\text { CHI }\end{array}$ & Span \\
\hline \multirow{3}{*}{$\begin{array}{l}\text { Zone 5, } \\
\text { Moist }\end{array}$} & Base HVAC \& Base HP & 55 & 81 & \multirow{3}{*}{26} & 55 & 64 & \multirow{3}{*}{9} \\
\hline & SEER 13-AFUE 96 & 47 & 73 & & 47 & 56 & \\
\hline & SEER 14-HSPF 9.0 & 53 & 79 & & 53 & 62 & \\
\hline \multirow{3}{*}{$\begin{array}{l}\text { Zone 5, } \\
\text { Dry }\end{array}$} & Base HVAC \& Base HP & 58 & 82 & \multirow{3}{*}{24} & 58 & 65 & \multirow{3}{*}{7} \\
\hline & SEER 13-AFUE 96 & 53 & 77 & & 53 & 60 & \\
\hline & SEER 14-HSPF 9.0 & 56 & 80 & & 56 & 63 & \\
\hline \multirow{3}{*}{$\begin{array}{l}\text { Zone 6, } \\
\text { Moist }\end{array}$} & Base HVAC \& Base HP & 55 & 79 & \multirow{3}{*}{24} & 55 & 63 & \multirow{3}{*}{8} \\
\hline & SEER 13-AFUE 96 & 48 & 72 & & 48 & 56 & \\
\hline & SEER 14-HSPF 9.0 & 54 & 78 & & 54 & 62 & \\
\hline \multirow{3}{*}{$\begin{array}{l}\text { Zone 6, } \\
\text { Dry }\end{array}$} & Base HVAC \& Base HP & 58 & 81 & \multirow{3}{*}{23} & 58 & 65 & \multirow{3}{*}{7} \\
\hline & SEER 13-AFUE 96 & 51 & 74 & & 51 & 58 & \\
\hline & SEER 14-HSPF 9.0 & 56 & 79 & & 56 & 63 & \\
\hline \multirow{3}{*}{ Zone 7} & Base HVAC \& Base HP & 53 & 77 & \multirow{3}{*}{24} & 53 & 60 & \multirow{3}{*}{7} \\
\hline & SEER 13-AFUE 96 & 44 & 68 & & 44 & 51 & \\
\hline & SEER 14-HSPF 9.0 & 52 & 76 & & 52 & 59 & \\
\hline \multirow{3}{*}{ Zone 8} & Base HVAC \& Base HP & 55 & 78 & \multirow{3}{*}{23} & 55 & 60 & \multirow{3}{*}{5} \\
\hline & SEER 13-AFUE 96 & 45 & 68 & & 45 & 50 & \\
\hline & SEER 14-HSPF 9.0 & 55 & 78 & & 55 & 60 & \\
\hline
\end{tabular}

${ }^{1}$ Corresponding HERS Index.

${ }^{2}$ In most scenarios, the home size and type of appliances used were the most significant characteristics. However, these varied by climate zone.

${ }^{3}$ HVAC efficiencies shown in the table include a Federal minimum set and the highest gas furnace and heat pump efficiencies analyzed. 



\section{Acknowledgments}

This analysis was conducted by the Pacific Northwest National Laboratory (PNNL) for the U.S. Department of Energy's Building Energy Codes Program (BECP). The authors would like to thank Mr. Jeremiah Williams, Project Manager of the Residential Building Energy Codes Program, for his dedicated support and guidance throughout the project. The authors would also like to thank Mr. David Cohan, Program Manager of the Building Energy Codes Program, for his insightful comments and guidance during the final stages of the preparation of this document.

The authors would like to thank all the industry experts who volunteered their time to provide thought-provoking comments on the report during the external peer review. Their reviews have made this report a better technical resource. The efforts of the following experts who peer reviewed an earlier draft of this report are deeply appreciated:

$$
\begin{aligned}
& \text { Mr. Steve Baden, Executive Director, Residential Energy Services Network (RESNET) } \\
& \text { Mr. Philip Fairey, Deputy Director, Florida Solar Energy Center (FSEC) } \\
& \text { Dr. David Goldstein, Co-Director, Energy Program, National Resources Defense Council } \\
& \text { (NRDC) }
\end{aligned}
$$$$
\text { Mr. Eric Makela, Partner, Brit-Makela Group }
$$$$
\text { Mr. Jim Peterson, President of the Board, Residential Energy Services Network (RESNET) }
$$

Last but not least, the authors would like to specially thank Ms. Bing Liu, Program Manager of BECP at PNNL, for her continued guidance and support throughout the project. Finally, the authors greatly appreciate the technical review and comments provided by Ms. Supriya Goel and Mr. Bob Lucas at PNNL. 


\section{Acronyms and Abbreviations}

AC

ACH50

AFUE

ASHRAE

CFA

CHI

DOE

$\mathrm{E} / \mathrm{W}$

ERI

${ }^{\circ} \mathrm{F}$

HERS

HSPF

HVAC

ICC

IECC

nMEUL

N/S

$\mathrm{Pa}$

RESNET

SEER

SHGC

SRD

WFR air conditioning

air changes per hour at $50 \mathrm{~Pa}$

annual fuel utilization efficiency

American Society of Heating, Refrigerating and Air-Conditioning Engineers

conditioned floor area

Corresponding HERS Index

U.S. Department of Energy

east-west

Energy Rating Index

degree(s) Fahrenheit

Home Energy Rating System

heating seasonal performance factor

heating, ventilating, and air conditioning

International Code Council

International Energy Conservation Code

normalized Modified End-Use Load

north-south

pascal(s)

Residential Energy Services Network

seasonal energy efficiency ratio

solar heat gain coefficient

Standard Reference Design

window-floor ratio 


\section{Contents}

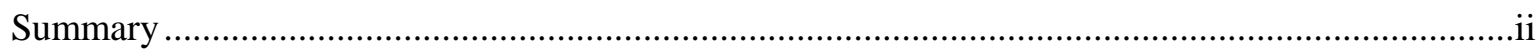

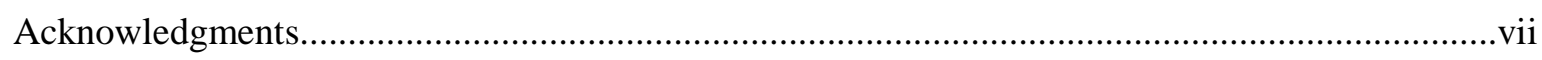

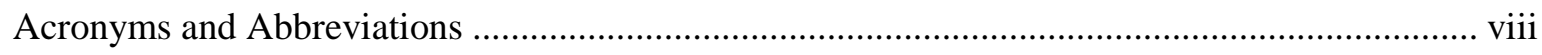

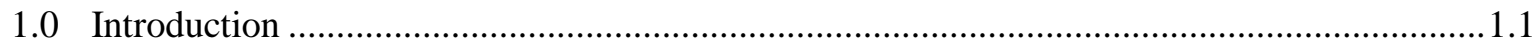

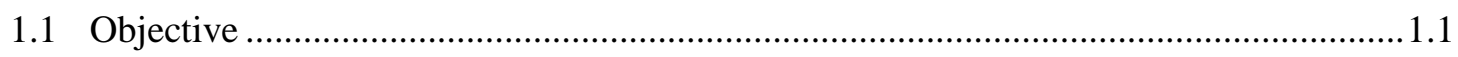

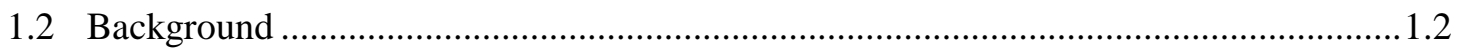

2.0 Comparing the RESNET HERS Index and the 2012 IECC ...........................................2.1

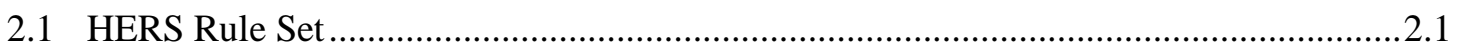

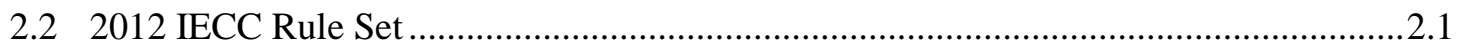

2.3 Key House Characteristics Analyzed .......................................................................2.2

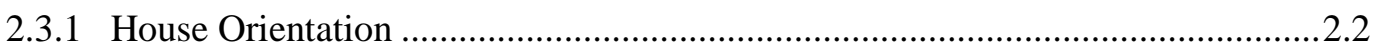

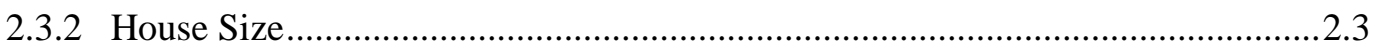

2.3.3 Appliances, Lighting, and Internal Gains.....................................................2.3

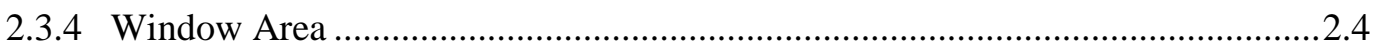

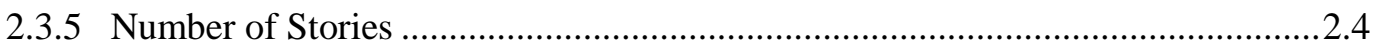

2.3.6 Foundation Type ….................................................................................... 2.4

2.3.7 Mechanical Equipment Type and Efficiency …................................................

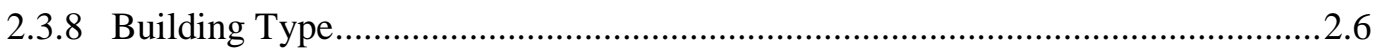

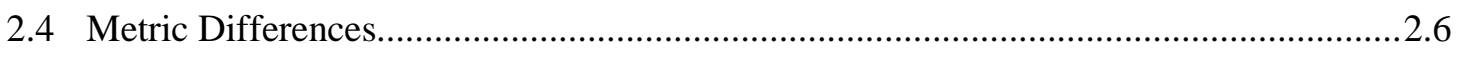

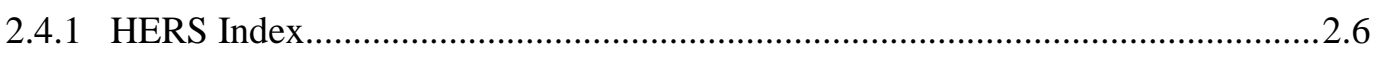

2.4.2 IECC Compliance Ratio................................................................................. 2.6

2.5 Interpreting the Correlation between the HERS Index and the IECC

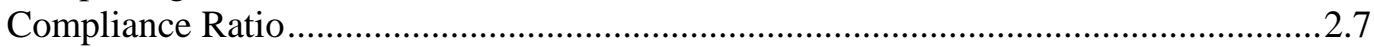

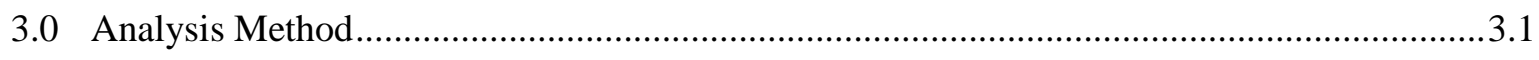

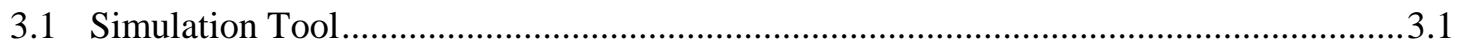

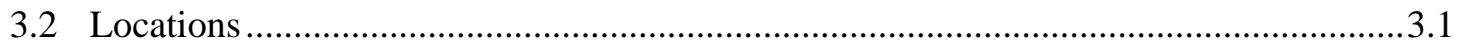

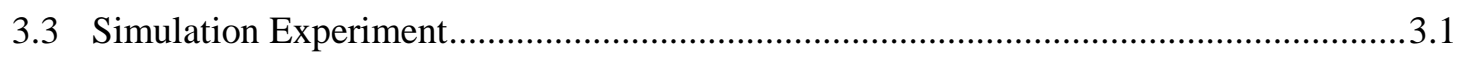

3.4 Calculating Corresponding HERS Index Values........................................................ 3.3

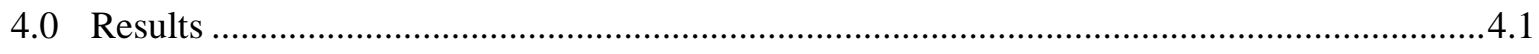

4.1 Ranges of Corresponding HERS Indexes ............................................................. 4.1

4.1.1 Volatility of Corresponding HERS Index to Individual Building

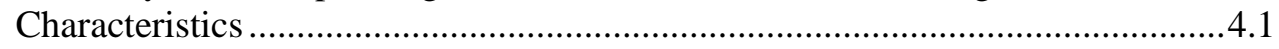

4.1.2 Volatility of Corresponding HERS Index to HVAC Efficiency ........................ 4.10

4.1.3 Joint Volatility of Corresponding HERS Index across Multiple Building

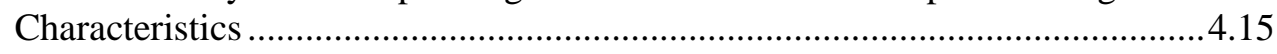

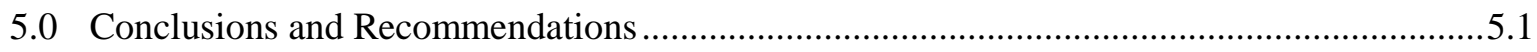

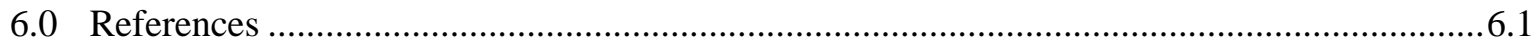


Appendix - Corresponding HERS Index Graphics ............................................................ 


\section{Figures}

2.1. Hypothetical Perfect Relationship Between the 2012 IECC Compliance Ratio and the HERS Index

3.1. Illustration of Curve Fit to Minimize Bias in Identifying Corresponding HERS Index 3.4

4.1. Volatility of Corresponding HERS Index to Individual Characteristics: Zone 1, Moist 4.3

4.2. Volatility of Corresponding HERS Index to Individual Characteristics: Zone 2, Moist 4.3

4.3. Volatility of Corresponding HERS Index to Individual Characteristics: Zone 2, Dry 4.4

4.4. Volatility of Corresponding HERS Index to Individual Characteristics: Zone 3, Moist 4.4

4.5. Volatility of Corresponding HERS Index to Individual Characteristics: Zone 3, Dry 4.5

4.6. Volatility of Corresponding HERS Index to Individual Characteristics: Zone 3, Marine 4.5

4.7. Volatility of Corresponding HERS Index to Individual Characteristics: Zone 4, Moist 4.6

4.8. Volatility of Corresponding HERS Index to Individual Characteristics: Zone 4, Dry 4.6

4.9. Volatility of Corresponding HERS Index to Individual Characteristics: Zone 4, Marine 4.7 4.10. Volatility of Corresponding HERS Index to Individual Characteristics: Zone 5, Moist 4.7

4.11. Volatility of Corresponding HERS Index to Individual Characteristics: Zone 5, Dry 4.8

4.12. Volatility of Corresponding HERS Index to Individual Characteristics: Zone 6, Moist 4.8 4.13. Volatility of Corresponding HERS Index to Individual Characteristics: Zone 6, Dry 4.9

4.14. Volatility of Corresponding HERS Index to Individual Characteristics: Zone 7 4.9 4.15. Volatility of Corresponding HERS Index to Individual Characteristics: Zone 8 


\section{Tables}

S.1. Volatility of Corresponding HERS Indexes ........................................................................iv

2.1. House Orientation Scenarios Analyzed ..............................................................................2.2

2.2. Mechanical Equipment Types and Efficiencies Analyzed...................................................2.5

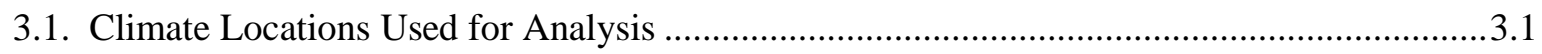

3.2. Building Characteristics/Parameters Analyzed.....................................................................

3.3. Component Characteristics Varied for the Three Prototype Configurations ...........................3.5

4.1. Baseline Characteristics Used in Assessing Volatility of Individual Building

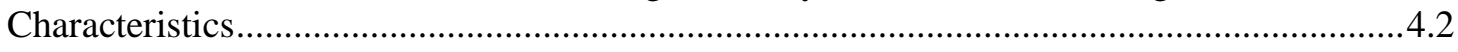

4.2. Impact of HVAC Efficiency on Corresponding HERS Index for Zone 1, Moist .................4.10

4.3. Impact of HVAC Efficiency on Corresponding HERS Index for Zone 2, Moist .................4.11

4.4. Impact of HVAC Efficiency on Corresponding HERS Index for Zone 2, Dry ....................4.11

4.5. Impact of HVAC Efficiency on Corresponding HERS Index for Zone 3, Moist ..................4.11

4.6. Impact of HVAC Efficiency on Corresponding HERS Index for Zone 3, Dry …................ 4.12

4.7. Impact of HVAC Efficiency on Corresponding HERS Index for Zone 3, Marine ................ 4.12

4.8. Impact of HVAC Efficiency on Corresponding HERS Index for Zone 4, Moist .................4.12

4.9. Impact of HVAC Efficiency on Corresponding HERS Index for Zone 4, Dry …................4.13

4.10. Impact of HVAC Efficiency on Corresponding HERS Index for Zone 4, Marine ..............4.13

4.11. Impact of HVAC Efficiency on Corresponding HERS Index for Zone 5, Moist ................4.13

4.12. Impact of HVAC Efficiency on Corresponding HERS Index for Zone 5, Dry ...................4.14

4.13. Impact of HVAC Efficiency on Corresponding HERS Index for Zone 6, Moist ................4.14

4.14. Impact of HVAC Efficiency on Corresponding HERS Index for Zone 6, Dry ..................4.14

4.15. Impact of HVAC Efficiency on Corresponding HERS Index for Zone 7 .........................4.15

4.16. Impact of HVAC Efficiency on Corresponding HERS Index for Zone 8 .........................4.15

4.17. Corresponding HERS Index Ranges for Zone 1, Moist...................................................4.18

4.18. Corresponding HERS Index Ranges for Zone 2, Moist....................................................4.18

4.19. Corresponding HERS Index Ranges for Zone 2, Dry ....................................................4.19

4.20. Corresponding HERS Index Ranges for Zone 3, Moist......................................................4.19

4.21. Corresponding HERS Index Ranges for Zone 3, Dry ....................................................4.19

4.22. Corresponding HERS Index Ranges for Zone 3, Marine ................................................4.20

4.23. Corresponding HERS Index Ranges for Zone 4, Moist...................................................4.20

4.24. Corresponding HERS Index Ranges for Zone 4, Dry .....................................................4.20

4.25. Corresponding HERS Index Ranges for Zone 4, Marine ...............................................4.21

4.26. Corresponding HERS Index Ranges for Zone 5, Moist..................................................4.21

4.27. Corresponding HERS Index Ranges for Zone 5, Dry ......................................................4.21

4.28. Corresponding HERS Index Ranges for Zone 6, Moist...................................................4.22

4.29. Corresponding HERS Index Ranges for Zone 6, Dry .......................................................4.22

4.30. Corresponding HERS Index Ranges for Zone 7 .........................................................22 


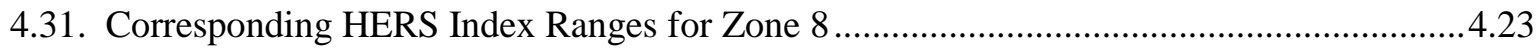





\subsection{Introduction}

This analysis was conducted by the Pacific Northwest National Laboratory (PNNL) for the U.S. Department of Energy (DOE) in support of DOE's Building Energy Codes Program (BECP). The analysis investigates the relationship between the Residential Energy Services Network (RESNET) Home Energy Rating System (HERS) Index and the simulation-based Performance Path used in the International Energy Conservation Code (IECC). In order to evaluate the correlation between the HERS rule set and the IECC Performance Path, energy analyses are carried out using the single-family prototype developed by PNNL to support U.S. Department of Energy for its energy and economic analyses of residential energy codes (Taylor et al. 2012; Mendon et al. 2013). These prototype building models cover a range of building characteristics in 15 climate locations and can be free downloaded from http://www.energycodes.gov/development/residential/iecc_models.

\subsection{Objective}

The objective of this analysis is to evaluate the relationship between RESNET's HERS Index and the Simulated Performance Alternative compliance path (often called the "Performance Path") of the IECC by identifying HERS Index values that correspond to minimal IECC compliance for homes with a wide variety of characteristics. These "Corresponding HERS Index" values are expected to be useful to states and other building code jurisdictions considering development or adoption of HERS-based compliance paths in their residential energy codes. Note that this analysis compares how the two systems (Performance Path and HERS) differ in regard to compliance, not necessarily energy consumption. As will be discussed in ensuing sections, the two systems cover different energy end uses. Because the HERS Index accounts for energy uses that are outside the IECC's scope, the correspondence (or lack thereof) between a home's HERS Index and its compliance via the Performance Path does not imply a similar correspondence with regard to whole-building energy use.

Although several states and building code jurisdictions have historically included HERS-based compliance options in their residential energy codes, the recent inclusion of an Energy Rating Index (ERI) compliance path ${ }^{1}$ in the 2015 IECC is likely to result in substantial proliferation of such compliance options in state building codes. The popularity of RESNET's HERS will likely make HERS the index of choice for many builders. This analysis is designed to provide technical backing to states and other jurisdictions considering adopting the 2015 IECC or developing a similar HERS or ERI-based path for their existing codes. Because the HERS Index is known to differ in many ways from the IECC's Performance Path, it is anticipated that jurisdictions will have questions about the equivalence of different compliance paths, and some may even consider amending the 2015 IECC to accommodate local policy or building preferences. Policy makers might use the Corresponding HERS Index ranges established in this report to inform the decisions involved in such processes.

\footnotetext{
${ }^{1}$ The ERI path will be in the 2015 IECC, which is not yet published as of this writing. Information can be obtained from the ICC’s Code Development web pages (http://www.iccsafe.org/cs/codes/Pages/cycle.aspx).
} 


\subsection{Background}

Because the 2015 IECC was not yet available at the time this analysis was conducted, the analysis was based on the 2012 IECC. However, from information available from the International Code Council (ICC) about its code development process, it is now known that the prescriptive requirements that affect the building parameters and methodology used in this analysis and the Performance Path of the 2015 IECC will not be materially different from the 2012 edition. Consequently, unqualified reference to the "IECC" in this report applies equally to the 2012 and 2015 editions.

The IECC Performance Path (Section R405) (ICC 2011) compares a Proposed Design against a Standard Reference Design (SRD) that exactly meets the code's prescriptive requirements for residential buildings. Compliance is achieved when the estimated energy cost of the Proposed Design is no more than the estimated energy cost of the SRD based on computer simulation of the two home prototypes according to an IECC-defined set of rules. The IECC does not concern itself with the magnitude of any estimated difference in energy cost between the two homes, only with the sense of the comparison. However, for this analysis a Compliance Ratio has been defined to facilitate quantitative comparisons with the RESNET HERS Index (RESNET 2013). The Compliance Ratio is defined as the energy cost of the Proposed Design divided by the energy cost of the 2012 IECC SRD. Consequently, a Compliance Ratio of 1.0 represents a minimally compliant home, while lower numbers indicate increased energy performance and higher numbers represent decreased energy performance.

The IECC defines energy performance in terms of estimated annual energy cost. ${ }^{1}$ The code covers heating, cooling, water-heating, and lighting end uses, but allows no credit in the Performance Path for changes to the lighting end use or for improvements in equipment efficiency. The IECC contains a table of specifications that govern the various simulation assumptions necessary for estimating annual energy performance.

The HERS Index is a rating system that compares a candidate home (called the Rated Home) against a reference home known as the HERS Reference Home. The overall energy characteristics of the HERS Reference Home are based approximately on the 2006 IECC. $^{2}$ The HERS Index is a ratio defined such that the HERS Reference Home has a HERS Index of 100, while a net-zero energy home has a HERS Index of zero. The lower the index value for a home, the more energy efficient it is compared to the HERS Reference Home. Each one-point decrease in the HERS Index corresponds to a nominal 1\% reduction in whole-building energy performance compared to the HERS Reference Home.

RESNET defines a HERS rule set that must be used in estimating the energy performance of the HERS Reference Home and Rated Home. The HERS rule set differs from the IECC Performance Path methodology in terms of both the energy-performance metric and the credit available for energy end uses included in its calculation. The HERS Index is based on a RESNET-defined performance metric known as the normalized Modified End-Use Load (nMEUL) (Fairey et al. 2000). The nMEUL was designed to allow the same HERS Index scale to apply to homes using any fuel and equipment type for heating. This

\footnotetext{
${ }^{1}$ At the code user's option, annual source energy can be used as an alternative to annual energy cost. This analysis considers only the energy cost approach.

2 The RESNET Reference Home is actually more closely related to the 2004 Supplement to the 2003 IECC, which differs only slightly from the 2006 IECC.
} 
differs from the IECC Performance Path, which compares the two homes by keeping fuels consistent. Several beyond-code programs have accepted HERS, or a modified version of HERS, as a metric for program qualification. The HERS Index allows a broader scope of house features to receive performance credit than does the IECC. For example, the HERS methodology allows credit for high-efficiency HVAC equipment while IECC does not.

Analyses are carried out using the single-family prototype building in the DOE Methodology for Evaluating Cost-Effectiveness of Residential Energy Code Changes (Taylor et al. 2012), modified as necessary to match HERS or IECC rule sets and the suite of building characteristics under evaluation. Energy simulations are completed for 15 climate locations corresponding to all U.S. climate zones and moisture regimes as defined in the 2012 IECC (ICC 2011). 



\subsection{Comparing the RESNET HERS Index and the 2012 IECC}

The Residential Energy Services Network (RESNET) Home Energy Rating System (HERS) standards (RESNET 2013) and the 2012 International Energy Conservation Code (IECC) Performance Path both define distinct rule sets for comparing a candidate ${ }^{1}$ home with a baseline home. The two approaches are based on different baseline energy efficiency assumptions, use different metrics of comparison, and have different terminology, but the fundamental premises are similar. The HERS and 2012 IECC rule sets are described in the following sections.

\subsection{HERS Rule Set}

The HERS Reference Home contains energy efficiency measures based approximately on the minimum requirements of the 2006 IECC and is geometrically identical to the Rated Home. The Reference Home is a wood-frame construction with an $18 \%$ window-floor ratio. Opaque envelope assemblies and vertical fenestration are set to match specified U-factor and solar heat gain coefficient (SHGC) values in the 2006 IECC. Ventilation rates are specified for attics and crawlspaces. The envelope air exchange rate is specified at 8.9 air changes per hour at $50 \mathrm{~Pa}$ (ACH50) for all climate zones and does not include the mechanical ventilation rate, even if the Rated Home has mechanical ventilation. If the Rated Home is equipped with a mechanical ventilation system, the HERS Reference Home accounts for the additional fan energy use (based on the conditioned floor area and number of bedrooms), but not for the additional air exchange rate. System efficiencies are specified at the prevailing federal minimum requirements for heating, cooling, and water-heating systems. The HERS Reference Home is required to be modeled with a thermostat having constant set points of $78^{\circ} \mathrm{F}$ for cooling and $68^{\circ} \mathrm{F}$ for heating.

The Rated Home is simulated as built (or as designed). The actual air exchange rate is required to be determined by a blower door test in accordance with the procedure specified in the 2001 ASHRAE Handbook: Fundamentals (ASHRAE 2001). Internal gains are the same as in the Reference Home unless high-efficiency appliances are used, in which case the internal loads are determined through procedures specified by the standards. The annual lighting energy of the Rated Home differs from that in the Reference Home based on the fraction of lighting that is energy efficient.

\subsection{IECC Rule Set}

Like the HERS rule set, the 2012 IECC defines its Standard Reference Design (SRD) as being geometrically identical to the Proposed Design. It assumes wood-frame construction with vented attics for the SRD. It sets the window area equal to that of the Proposed Design up to 15\% of conditioned floor area, but restricts it to 15\% if the Proposed Design has greater window area. Envelope U-factors and SHGC values are set equal to the code's minimum prescriptive requirements. Envelope leakage is set to 5.0 ACH50 for IECC Climate Zones 1 and 2 (ICC 2011), and 3.0 ACH50 for Climate Zones 3 through 8. Mechanical ventilation is mandatory for the 2012 IECC and the SRD is required to account for the in-

\footnotetext{
${ }^{1}$ For HERS Index calculations, a candidate home is called the Rated Home; for IECC compliance, it is called the Proposed Home.
} 
creased air exchange rate, thus not penalizing the Proposed Design for the thermal impact of ventilation. The 2012 IECC Performance Path does not consider end uses other than heating, cooling, and domestic hot water; hence, internal gains are specified as a total heat gain per day and are required to be the same in the SRD and Proposed Design. Equipment efficiencies are required to be the same for both designs, with minimum efficiencies in accordance with the prevailing federal minimum efficiency requirements. The $\mathrm{SRD}$ is required to be simulated with a manual thermostat with the cooling set point at $75^{\circ} \mathrm{F}$ and the heating set point at $72^{\circ} \mathrm{F}$.

\subsection{Key House Characteristics Analyzed}

Because of the rule set differences discussed above, the HERS Index and IECC Compliance Ratio behave differently in response to changes in various house characteristics. This section describes the characteristics analyzed in this report.

\subsubsection{House Orientation}

House orientation—or, more specifically, glazing orientation—can have significant impact on the heating and cooling loads of a home, mainly due to solar heat gain. Because both the HERS Reference Home and the IECC SRD have equal window area facing each of the four cardinal directions, similar impacts are expected on the resultant HERS Index and IECC Compliance Ratio. However, because HERS is a whole-building energy index, whereas the IECC Compliance Ratio considers only a subset of end uses, the impact of house orientation could potentially differ between the two metrics.

Solar heat gain through glazing is generally helpful during the heating season and harmful during the cooling season, so this analysis considers both the advantageous and detrimental house orientation scenarios, along with a baseline equally distributed scenario, as shown in Table 2.1. Because most newly constructed homes are built in subdivisions where the homes are placed on narrow lots with minimal street frontage, it can be assumed that these homes are likely to have most of their glazing facing either the street or the backyard, which means glazing is predominantly on two opposing faces of each home. The single-family prototype building used in this analysis is assumed either to have glazing equally distributed on all four faces or to have $80 \%$ of the total glazing area on two opposing walls and $20 \%$ on the other two. In the latter case, the house is oriented with the $80 \%$ faces pointing either north-south (N/S) or eastwest (E/W) to result in best- or worst-case scenarios, respectively.

Table 2.1. House Orientation Scenarios Analyzed

\begin{tabular}{ccccc}
\hline & \multicolumn{4}{c}{ Glazing Fraction Facing Each Direction (\%) } \\
\cline { 2 - 5 } Orientation Scenario & North & East & South & West \\
\hline Best & 40 & 10 & 40 & 10 \\
Neutral & 25 & 25 & 25 & 25 \\
Worst & 10 & 40 & 10 & 40 \\
\hline
\end{tabular}




\subsubsection{House Size}

House size directly affects relative heating and cooling loads and the resultant energy use due to changes in the surface-to-volume ratio of the home. The shares of energy attributable to heating, cooling, water-heating, and lighting consequently differ between smaller and larger homes. Although the HERS and IECC Performance Path methodologies handle house size in much the same way, the Corresponding HERS Index may be affected by the size of the home because the HERS Index is a whole-house metric while the IECC Compliance Ratio is based on a subset of energy end uses. There are also significant differences in the assumed air leakage rates of the respective baseline homes (HERS Reference Home and IECC SRD), which have the potential to skew the energy shares of the relevant end uses.

This analysis evaluates the impact of house size on the Corresponding HERS Index by analyzing three house sizes: a smaller $1200 \mathrm{ft}^{2}$ home, an average $2400 \mathrm{ft}^{2}$ home, and a relatively large $5000 \mathrm{ft}^{2}$ home. The three homes are assumed to have two, three, and four bedrooms, respectively.

\subsubsection{Appliances, Lighting, and Internal Gains}

The energy consumed by lighting, appliances, and other energy-using devices and the corresponding internal heat gains are handled very differently by the HERS and IECC metrics. The IECC Performance Path specifies a total daily internal load that depends on the conditioned floor area and number of bedrooms. This value is independent of climate zone and other house characteristics and is the same for the IECC SRD and the Proposed Design. Thus, lower energy consumption or internal heat generation of energy-efficient appliances is not accounted for. However, the 2012 IECC requires $75 \%$ of all permanently installed luminaires to have high-efficacy lamps, which affects the heat gain from lighting. The DOE methodology (Taylor et al. 2012) accounts for the reduction in internal gains and energy savings resulting from the lighting provisions in the IECC, and that approach is used in this analysis. That is, the IECC Compliance Ratio includes lighting energy in both its numerator and denominator. Because lighting energy is the same in both numerator and denominator, it has no effect on the results of this analysis. ${ }^{1}$

The HERS methodology divides internal gains into three parts - appliances, lighting, and occupants-and includes a procedure for crediting energy savings from energy-efficient appliances when present in the home. HERS thus allows credit for energy-efficient appliances and accounts for the changes in internal gains while the IECC Performance Path does not. Energy-efficient appliances also affect the level of internal heat gains and the resulting heating and cooling loads and energy. Thus, presence of energy-efficient appliances is expected to impact the Corresponding HERS Index values. In order to evaluate this impact, two scenarios are analyzed—one with standard appliances and one with efficient ENERGY STAR appliances. ${ }^{2}$ While it is more common for dishwashers to be installed in new homes prior to sale, this analysis also considers efficient clothes-washers and refrigerators on the Corresponding HERS Index.

\footnotetext{
${ }^{1}$ Lighting does change the magnitude of the Compliance Ratio, but since the Ratio is used only as a tool to establish points of similar compliance between the IECC Performance Path and a HERS-based path, the results of the analysis are not changed.

${ }^{2}$ See http://www.energystar.gov/index.cfm?c=products.pr_find_es_products.
} 


\subsubsection{Window Area}

Window Area is handled differently by HERS and the IECC Performance Path. The IECC sets the window-floor ratio (WFR) of the SRD at 15\% of conditioned floor area if the Proposed Design has 15\% or more windows. However, if the Proposed Design's WFR is less than 15\%, the SRD must have the same window area as the Proposed Design. Thus, the IECC effectively penalizes homes with a WFR greater than $15 \%$, but gives no credit for homes with a WFR less than $15 \%$. In contrast, the HERS rules set the WFR of the Reference Home to $18 \%$ irrespective of the Rated Home's window area. Thus, HERS effectively penalizes homes with a WFR greater than $18 \%$, and gives credit to homes with a WFR less than $18 \%$.

Typical home WFRs average close to 15\% (Lucas 2009), with slightly higher WFRs occurring in southern zones. Other attributes being equal, the $18 \%$ specification in the HERS Reference Home is less stringent than the $15 \%$ or lower specification for the IECC SRD. These differences are expected to potentially impact Corresponding HERS Index values because of the added credit for average and lower window areas given by HERS but not by the IECC. In order to evaluate this impact, it is necessary to analyze a WFR smaller than $15 \%$, one between $15 \%$ and $18 \%$ and a third one larger than $18 \%$. Thus, three levels of WFR are analyzed: $12 \%, 16 \%$, and $25 \%$.

\subsubsection{Number of Stories}

The number of stories in a home can have an impact on its heating and cooling loads because it tends to affect the surface-to-volume ratio and the relative amounts of ceiling area, wall area, and floor area. While the HERS and IECC rule sets deal similarly with the number of stories, this parameter has the potential to impact the Corresponding HERS Index values because of the aforementioned differences in the end uses included in the two metrics. While not uncommon, homes with three or more stories are much less common than one or two-storied homes. Thus, this analysis evaluates two scenarios: a one-story building and a two-story building.

\subsubsection{Foundation Type}

Foundation type directly affects heat gains and losses through the floor of the house. While foundation type is handled exactly the same way by the HERS and the IECC Performance Path, it has the potential to impact the Corresponding HERS Index values because it can indirectly affect a home's size and surface-to-volume ratio. The four foundation types typically seen in new homes are slab-on-grade, vented crawlspace, heated basement, and unheated basement (Mendon et al. 2013). The thermal impact of unheated basements is expected to be similar to vented crawlspaces because they both involve an insulated floor separating the conditioned space from the unconditioned crawlspace or basement. Thus, this analysis evaluates the impact of three foundation types on the Corresponding HERS Index: slab-on-grade, vented crawlspace, and heated basement.

\subsubsection{Mechanical Equipment Type and Efficiency}

The IECC Performance Path requires the SRD to have the same mechanical equipment efficiencies as the Proposed Design, thus allowing no compliance credit for high-efficiency mechanical equipment. The HERS rule set, on the other hand, sets the Reference Home equipment efficiencies to the federal minimum efficiency requirements, while allowing the Rated Home to have proposed (actual) equipment effi- 
ciencies, thus allowing credit for high-efficiency equipment. This is a significant difference between the HERS Index and the IECC Compliance Ratio.

Equipment efficiency is evaluated differently than all other characteristics in this analysis. The range of equipment efficiencies analyzed is applied only to a single combination of the other home characteristics rather than including it in the full combinatorial simulation run set. The resulting impacts on that combination are then generalized to apply in a similar way to all combinations of characteristics. This was done primarily to lessen the computational burden and time requirements of the analysis. This approach is justified because mechanical system efficiency affects loads differently from the other analyzed characteristics - the home/envelope characteristics interact with each other to result in heating and cooling loads on the space, while equipment efficiencies merely determine the amount of energy required to meet those loads.

This analysis includes two primary heating/cooling system types-heat pump and gas furnace with central air conditioning (AC) — and evaluates the impact of several levels of system efficiency. The SEER and annual fuel utilization efficiency/ heating seasonal performance factor (AFUE/HSPF) levels are grouped into efficiency packages as summarized in Table 2.2 below. For each climate zone and system type one base package represents the current federal minimum requirements of an AFUE of 78\%, a SEER of 13, and an HSPF of 7.7. Depending on system type, one or more additional packages represent higher-efficiency levels. In some cases, a package represents a modest efficiency improvement defined to match the revised federal minimum standards initially expected to go into effect in 2015, which would have raised the minimum AFUE to $90 \%$ in the northern climates and $80 \%$ elsewhere and the minimum HSPF to 8.2 and 7.7, in the northern climates and elsewhere respectively, and would have raised the minimum SEER to 14 in the southern climates. In other cases, higher-efficiency levels intended to roughly correspond to the highest levels in common practice are included to generate a broad range of efficiency distributions.

Table 2.2. Mechanical Equipment Types and Efficiencies Analyzed

\begin{tabular}{|c|c|c|c|c|c|c|}
\hline \multirow[b]{2}{*}{$\begin{array}{l}\text { Climate } \\
\text { Zone }\end{array}$} & \multicolumn{3}{|c|}{ AC and Gas Furnace } & \multicolumn{3}{|c|}{ Electric Heat Pump (HP) } \\
\hline & $\begin{array}{c}\text { Efficiency } \\
\text { Package }\end{array}$ & SEER & AFUE & $\begin{array}{l}\text { Efficiency } \\
\text { Package }\end{array}$ & SEER & HSPF \\
\hline \multirow{4}{*}{$1-2$} & Base HVAC $^{(\mathrm{d})}$ & 13 & 78 & \multirow{2}{*}{ Base HP } & \multirow{2}{*}{13} & \multirow{2}{*}{7.7} \\
\hline & High-eff Gas 1 & 14 & 80 & & & \\
\hline & High-eff Gas 2 & 16 & 80 & \multirow{2}{*}{ High-eff HP } & \multirow{2}{*}{15} & \multirow{2}{*}{8.2} \\
\hline & High-eff Gas 3 & 20 & 80 & & & \\
\hline \multirow{4}{*}{$3-4$} & Base HVAC & 13 & 78 & \multirow{2}{*}{ Base HP } & \multirow{2}{*}{13} & \multirow{2}{*}{7.7} \\
\hline & High-eff Gas 1 & 14 & 80 & & & \\
\hline & High-eff Gas 2 & 16 & 94 & \multirow{2}{*}{ High-eff HP } & \multirow{2}{*}{15} & \multirow{2}{*}{9.0} \\
\hline & High-eff Gas 3 & 20 & 96 & & & \\
\hline \multirow{4}{*}{$5-8$} & Base HVAC & 13 & 78 & \multirow{2}{*}{ Base HP } & \multirow{2}{*}{13} & \multirow{2}{*}{7.7} \\
\hline & High-eff Gas 1 & 13 & 80 & & & \\
\hline & High-eff Gas 2 & 13 & 94 & \multirow{2}{*}{ High-eff HP } & \multirow{2}{*}{14} & \multirow{2}{*}{9.0} \\
\hline & High-eff Gas 3 & 13 & 96 & & & \\
\hline
\end{tabular}

SEER = seasonal energy efficiency ratio; AFUE = annual fuel utilization efficiency; HSPF = heating seasonal performance factor; HVAC = heating, ventilation and air conditioning. 


\subsubsection{Building Type}

Single-family and multifamily homes have multiple characteristics that can impact the Corresponding HERS Index differently. This analysis focuses on single-family detached construction, because it accounts for more than $80 \%$ of all new construction (Mendon et al. 2013) and HERS ratings are more common for single-family homes. However, while this analysis does not explicitly evaluate differences in building type, it is expected that the impacts may be an aggregation of the factors analyzed (e.g., the interactions of house size, internal gains, number of stories, etc., tend to embody some of the major differences between single- and multifamily homes).

\subsection{Metric Differences}

The IECC Performance Path and the HERS standards use different metrics to quantify energy performance. Although both are correlated with the energy consumption in a home, the quantities compared are different. The manner in which the computed metrics are compared between a baseline and a proposed or Rated Home also differ.

\subsubsection{HERS Index}

The HERS Index is a relative measure of energy efficiency performance, with a scale ranging from zero to (theoretically) infinity. A HERS Index score of zero would represent a net-zero energy home. A HERS Index score of 100 is defined to represent a home approximately compliant with the 2006 IECC. A HERS Index score greater than 100 implies the home is less efficient than the 2006 IECC standard home, while a score less than 100 indicates a more efficient home. Each one-point decrease in the HERS Index corresponds approximately to a 1\% reduction in energy consumption compared to the 2006 IECCbased HERS Reference Home. Thus, for example, a home with a HERS Index score of 90 is expected to be $10 \%$ more efficient than if it were to meet the minimum requirements of the 2006 IECC.

The HERS Index is the ratio of a Rated Home's performance to that of the HERS Reference Home, where performance is defined by the normalized Modified End-Use Loads (nMEUL). The nMEUL is based on simulated building loads (as opposed to energy consumption or energy cost). The indicated normalization is designed to allow homes to use the same HERS Index scale regardless of the fuel type(s) used for space conditioning and water-heating. The nMEUL incorporates whole-building loads, so all end uses are considered.

\subsubsection{IECC Compliance Ratio}

The IECC Performance Path bases compliance on a comparison of energy costs (or source energy) between the SRD and the Proposed Design. The Proposed Design is required to have an annual energy cost equal to or less than that of the SRD. Only heating, cooling, and water-heating end uses are considered for the energy-cost metric comparison. The DOE cost-effectiveness methodology (Taylor et al. 2012) used for this analysis includes lighting energy calculations in this metric for facilitating comparisons against older versions of the code that had no high-efficacy lighting requirements, but the 2012 IECC Performance Path gives no credit for a higher percentage of high-efficacy lighting. This analysis included lighting energy in both the numerator and denominator when calculating the IECC Compliance Ratio. While this affects the value of that ratio, it does not affect the results of this analysis because the 
Compliance Ratio is used only as a proxy to allow a quantitative relationship between the IECC Performance Path and the HERS Index. See Section 3.4 and Appendix A.1 for additional details.

The IECC Performance Path acknowledges only a binary result. If the energy cost of the Proposed Design is equal to or lower than that of the SRD, the home complies; otherwise it does not. The code does not concern itself with how much better (or worse) a Proposed Design might be relative to the SRD. However, to allow quantitative comparisons of the behavior of the HERS Index with that of the IECC Performance Path, an IECC Compliance Ratio has been defined for this analysis. The Compliance Ratio is simply the ratio of the energy cost of the Proposed Design to that of the SRD. Thus, a Compliance Ratio greater than 1.0 indicates noncompliance, and a lower Compliance Ratio represents better-thanstandard performance. Note that the IECC Compliance Ratio is anchored at 1.0 for a home that minimally complies with the 2012 IECC, while the HERS Index is anchored at 100 for a home that roughly complies with the 2006 IECC.

\subsection{Interpreting the Correlation between the HERS Index and the IECC Compliance Ratio}

As a result of the previously described differences between the HERS Index and the IECC Compliance Ratio, a one-to-one linear correspondence between the two metrics cannot be expected. Nonetheless, it is desirable that the nature of the two metrics' correlation be sufficiently understood to inform questions about how the 2015 IECC's ERI path might relate to its Performance Path. Considering what might be expected if there were a hypothetical "perfect" correlation may aid understanding how the two metrics relate. For the purpose of the present analysis, a perfect correlation would mean a relative improvement in energy performance on one of the scales would result in a similar relative improvement on the other scale. It also is desirable to have an explicable correspondence between the anchor points of the two scales (i.e., HERS Index of 100 = 2006 IECC; IECC Compliance Ratio of 1.0 = 2012 IECC).

PNNL has estimated the difference in energy performance between the 2006 IECC and 2012 IECC, on a national average basis, to be $32.1 \%$ (Mendon et al. 2013). Climate zone-specific averages from the same study range from $25.1 \%$ to $38.3 \%$. Based on that result, the common expectation of about $30 \%$ improvement between the 2006 and 2012 revisions can be used to define a hypothetical point of perfect correspondence between the two scales. The graph in Figure 2.1 illustrates this hypothetical correlation with a dashed red line. Note that a HERS Index score of 70 corresponds to an IECC Compliance Ratio of 1.0, thus reflecting the approximately 30\% improvement of the 2012 IECC over the 2006 IECC in this hypothetical correlation. ${ }^{1}$ Also note that a relative change in the HERS Index score corresponds to an identical relative change in the Compliance Ratio. This line of perfect correlation is shown for reference on all further graphics comparing the HERS Index and Compliance Ratio. It is shown only to aid in visualizing how the actual correlation between HERS and the Performance Path compares to the common expectation of a perfect correlation between the two metrics.

\footnotetext{
${ }^{1}$ Note that the choice of a HERS Index of 70 is merely for convenience in visualizing what may be a common expectation; it does not imply that 70 best represents a typical HERS Index for 2012 IECC-compliant homes.
} 


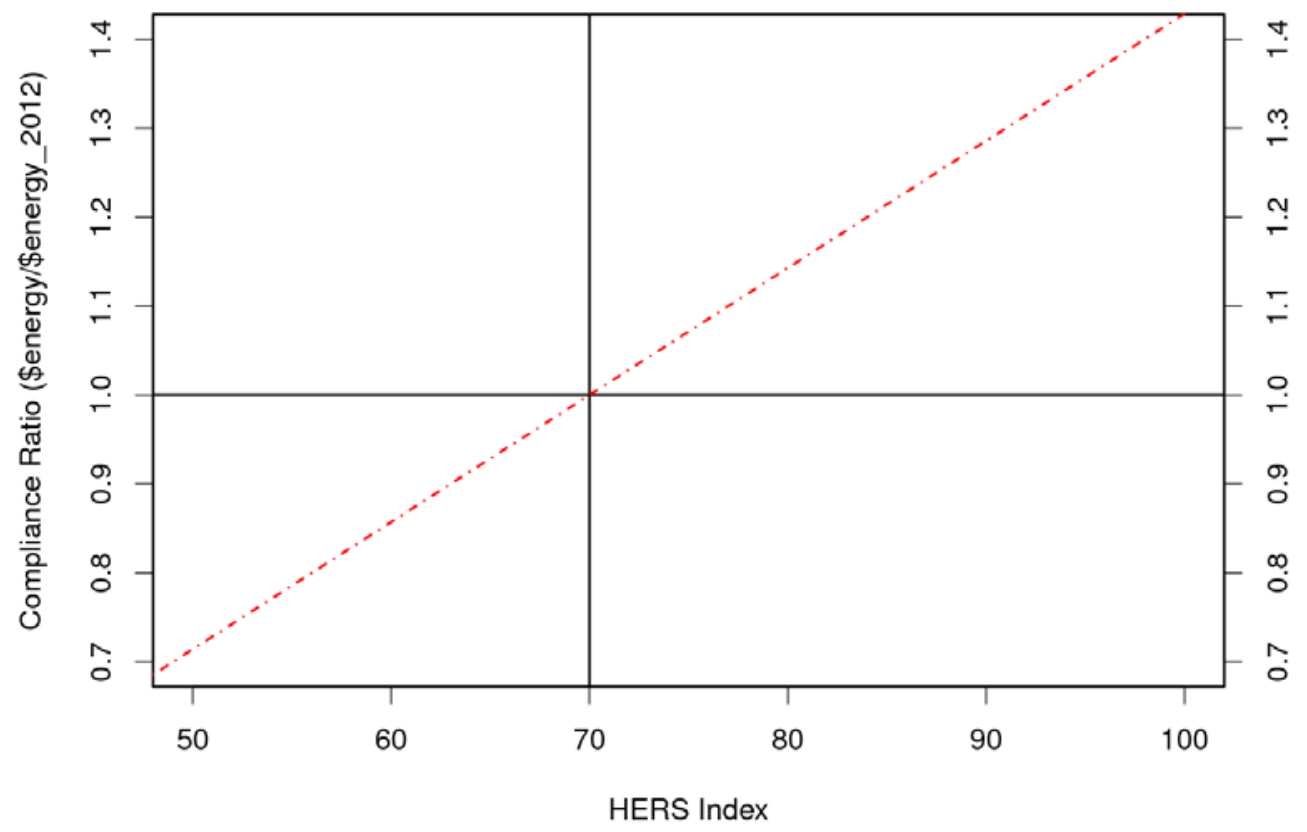

Figure 2.1. Hypothetical Perfect Relationship Between the 2012 IECC Compliance Ratio and the HERS Index 


\subsection{Analysis Method}

This section describes the simulation experiment and the data analysis methodology used in this analysis. The methodology used for calculating the Corresponding HERS Index (CHI), which forms the basis of the analysis, is also described in detail.

\subsection{Simulation Tool}

This analysis is conducted using EnergyPlus which is established as the primary simulation tool for analysis according to DOE's residential cost-effectiveness methodology (Taylor et al. 2012). EnergyPlus provides for a detailed hour-by-hour (or more frequent) simulation of energy consumption in a home throughout a full year, based on typical weather data for a location. It covers almost all aspects of residential envelopes, HVAC equipment and systems, water-heating equipment and lighting systems.

\subsection{Locations}

Simulations are conducted in one weather location per IECC climate zone, including a separate location for each moisture regime. The locations in Table 3.1 are selected to represent their respective climate zones (Briggs et al. 2002).

Table 3.1. Climate Locations Used for Analysis

\begin{tabular}{llcl}
\hline \multicolumn{1}{c}{ Location } & \multicolumn{1}{c}{ State } & Climate Zone & Moisture Regime \\
\hline Miami & Florida & 1 & Moist \\
Phoenix & Arizona & 2 & Dry \\
Houston & Texas & 2 & Moist \\
El Paso & Texas & 3 & Dry \\
San Francisco & California & 3 & Marine \\
Memphis & Tennessee & 3 & Moist \\
Albuquerque & New Mexico & 4 & Dry \\
Salem & Oregon & 4 & Marine \\
Baltimore & Maryland & 4 & moist \\
Boise & Idaho & 5 & Dry \\
Chicago & Illinois & 5 & Moist \\
Helena & Montana & 6 & Dry \\
Burlington & Vermont & 6 & Moist \\
Duluth & Minnesota & 7 & None defined \\
Fairbanks & Alaska & 8 & None defined \\
\hline
\end{tabular}

\subsection{Simulation Experiment}

The single-family prototype defined in the DOE cost-effectiveness methodology (Taylor et al. 2012) is used for this analysis. The prototype is configured to match the parameters evaluated in this analysis, described in Section 2.3 above and summarized in Table 3.2. The full combinatorial set of enve- 
lope/house parameters results in 324 individual buildings to be evaluated in each climate zone (3 house sizes $\times 3$ orientations $\times 2$ internal gain levels $\times 3$ WFRs $\times 2$ numbers of stories $\times 3$ foundations). These are augmented by six buildings configured with baseline or central levels of the envelope/house parameters and varying levels of equipment efficiency (four gas/AC levels plus two electric heat pump levels). This results in a total of 330 buildings to be evaluated in each climate location. For each evaluated building, both a HERS Index and an IECC Compliance Ratio must be calculated, and each of these metrics involves two energy simulations - one for the HERS Baseline or SRD and one for the Rated or Proposed Design. Thus there are $1320(330 \times 4)$ building energy simulations required for each location. Finally, as described in the next section, each individual building is evaluated at three overall efficiency levels to avoid accidental bias in the calculated Corresponding HERS Indexes, so there are $3960(1320 \times 3)$ EnergyPlus simulations per location. With 15 locations, the total number of simulation runs is 59,400.

Table 3.2. Building Characteristics/Parameters Analyzed

\begin{tabular}{|c|c|c|c|c|c|c|}
\hline Parameter & \multicolumn{6}{|c|}{ Values Analyzed } \\
\hline House Size & \multicolumn{6}{|c|}{$\begin{array}{l}1200 \mathrm{ft}^{2} \text { (2 bedrooms) } \\
2400 \mathrm{ft}^{2} \text { (3 bedrooms) } \\
5000 \mathrm{ft}^{2} \text { (4 bedrooms) }\end{array}$} \\
\hline House Orientation & \multicolumn{6}{|c|}{$\begin{array}{l}\text { Best (glazing } 40 \% \text { each on N/S, } 10 \% \text { each on E/W) } \\
\text { Worst (glazing } 10 \% \text { each on N/S, } 40 \% \text { each on E/W) } \\
\text { Neutral (glazing } 25 \% \text { on each of N/S/E/W) }\end{array}$} \\
\hline Internal Loads & \multicolumn{6}{|c|}{$\begin{array}{l}\text { Standard appliances } \\
\text { ENERGY STAR appliances }\end{array}$} \\
\hline WFR & \multicolumn{6}{|c|}{$\begin{array}{l}12 \% \\
16 \% \\
25 \%\end{array}$} \\
\hline Number of Stories & \multicolumn{6}{|l|}{$\begin{array}{l}1 \text { Story } \\
2 \text { Story }\end{array}$} \\
\hline Foundation Type & \multicolumn{6}{|c|}{$\begin{array}{l}\text { Slab-on-Grade } \\
\text { Vented Crawlspace } \\
\text { Heated Basement } \\
\end{array}$} \\
\hline \multirow{10}{*}{$\begin{array}{l}\text { Mechanical Equipment } \\
\text { Type and Efficiency }\end{array}$} & \multicolumn{3}{|c|}{ AC and Gas Furnace } & \multicolumn{3}{|c|}{ Electric Heat Pump } \\
\hline & $\begin{array}{l}\text { Climate } \\
\text { Zone }\end{array}$ & SEER & AFUE & $\begin{array}{l}\text { Climate } \\
\text { Zone }\end{array}$ & SEER & HSPF \\
\hline & \multirow{2}{*}{$1-2$} & $\begin{array}{l}13 \\
14\end{array}$ & $\begin{array}{l}78 \\
80\end{array}$ & \multirow{2}{*}{$1-2$} & 13 & 7.7 \\
\hline & & $\begin{array}{l}16 \\
20\end{array}$ & $\begin{array}{l}80 \\
80\end{array}$ & & 15 & 8.2 \\
\hline & \multirow{3}{*}{$3-4$} & 13 & 78 & \multirow{3}{*}{$3-4$} & \multirow{2}{*}{13} & \multirow[t]{2}{*}{7.7} \\
\hline & & 14 & 80 & & & \\
\hline & & $\begin{array}{l}16 \\
20\end{array}$ & $\begin{array}{l}94 \\
96\end{array}$ & & 15 & 9.0 \\
\hline & \multirow{3}{*}{$5-8$} & 13 & 78 & \multirow{3}{*}{$5-8$} & \multirow{2}{*}{13} & \multirow{2}{*}{7.7} \\
\hline & & 13 & 80 & & & \\
\hline & & $\begin{array}{l}13 \\
13\end{array}$ & 96 & & 14 & 9.0 \\
\hline
\end{tabular}




\subsection{Calculating Corresponding HERS Index Values}

A Corresponding HERS Index is defined as the HERS Index that corresponds to an IECC Compliance Ratio of exactly 1.0 for a given home. The simplest way to estimate a Corresponding HERS Index is to equip a prototype building with the minimum prescriptive efficiency levels of the 2012 IECC and calculate the corresponding HERS Index. However, the simple approach has a shortcoming in that using a single-building configuration to identify the Corresponding HERS Index has the potential to introduce unintentional bias of unknown magnitude based on the arbitrary choice of that configuration from among the many combinations of component efficiency levels that would comply via the Performance Path.

To avoid the bias and resulting noise in the results that might be introduced by relying on a single combination of levels for each analyzed home, this analysis uses an approach that bounds the prescriptive-minimum combination with both higher- and lower-efficiency combinations. For each given set of building parameters, three homes are analyzed: one at the 2012 IECC prescriptive-minimum efficiency levels, one with substantially higher-efficiency levels, and one with substantially lower-efficiency levels. This results in three HERS Index/IECC Compliance Ratio pairs. A simple curve is fit (by linear regression) through these three points and the Corresponding HERS Index is defined as the HERS Index value where the curve crosses the line representing an IECC Compliance Ratio of 1.0. This is illustrated in Figure 3.1. Earlier analyses conducted by Taylor et al (2013) explored this approach using a much larger set of 33 building-component-efficiency combinations and concluded that a smaller set would yield similar results.

This figure shows an example calculation of Corresponding HERS Index for three house sizes (three levels of conditioned floor area [CFA]) in a single climate location. In each panel, the calculated IECC Compliance Ratio is plotted against the calculated HERS Index. The dashed diagonal line is the line of expected correspondence discussed above in Section 2.5. In each panel three points are plotted: a middle one corresponding to the IECC prescriptive-minimum requirements, a higher-efficiency one that results in lower HERS Index and Compliance Ratio values, and a lower-efficiency one that results in higher HERS Index and Compliance Ratio values. A solid diagonal line represents a least-squares curve (line) fit to the three data points. A takeoff at Compliance Ratio $=1.0$, shown by the crossing vertical and horizontal dashed lines, gives the Corresponding HERS Index used in this analysis.

It is observed in this example that the line of expected correspondence is close to the curve fit through the three data points for the average home size of $2400 \mathrm{ft}^{2}$, but, the lines move apart for the smaller and larger homes and the Corresponding HERS Index values are lower (better) for the larger homes than the smaller homes. This illustrates the complexity of the correlation between the two metrics, showing that the hypothetical perfect " $30 \%$ better" expectation does not hold exactly and differs across differing home sizes.

Table 3.3 shows the IECC prescriptive-minimum base (or medium, M), higher-efficiency $(\mathrm{H})$, and lower-efficiency (L) parameter levels used for each climate zone. In each case, the air-distribution efficiency and mechanical ventilation requirements were maintained at the 2012 IECC levels for the IECC energy models and varied for the HERS energy models according to the HERS rule set. Note that the HERS Indexes calculated for this work are based on the procedures in RESNET 2013, but were not computed using RESNET-certified software. 


\section{Conditioned Floor Area}

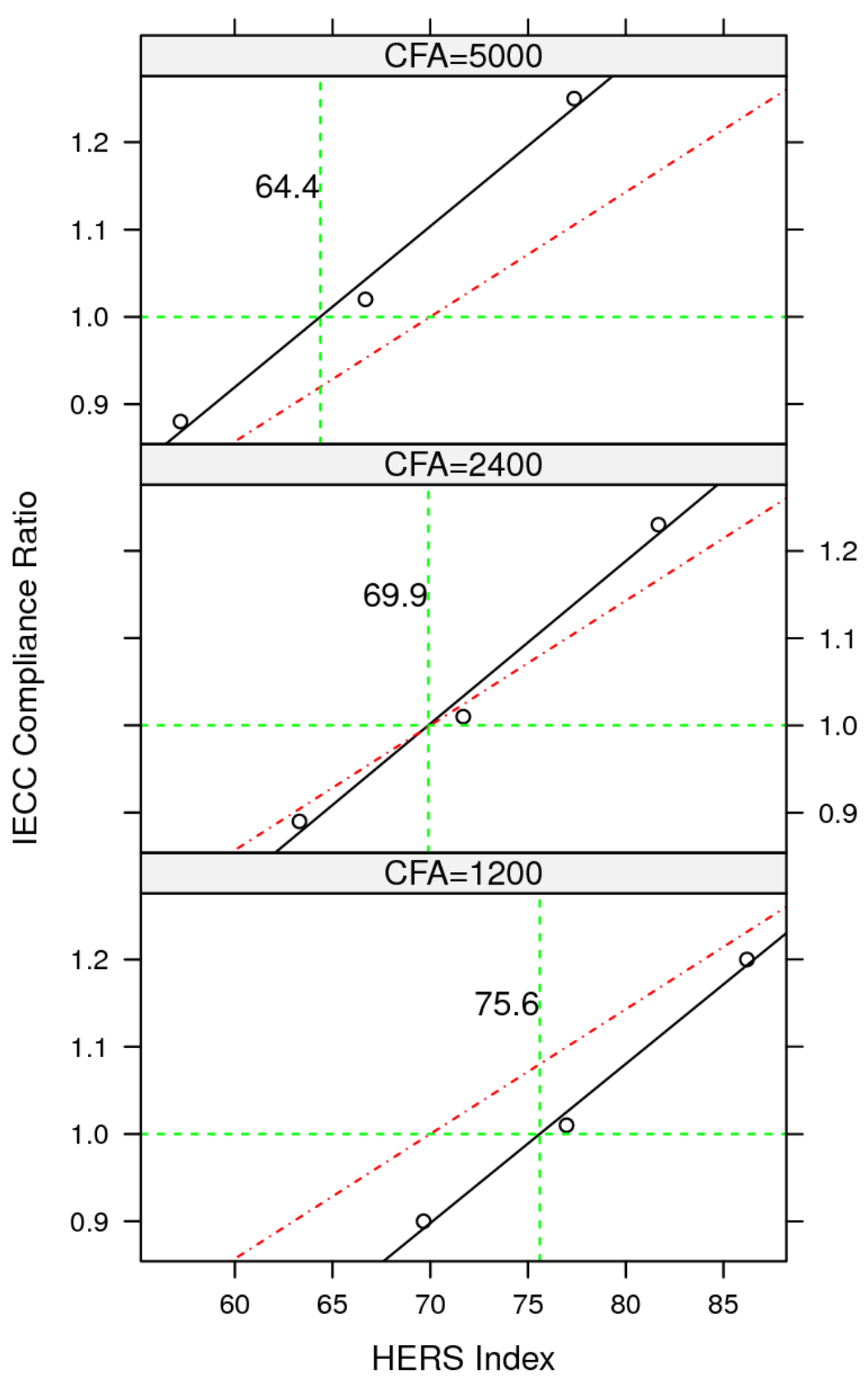

Figure 3.1. Illustration of Curve Fit to Minimize Bias in Identifying Corresponding HERS Index 
Table 3.3. Component Characteristics Varied for the Three Prototype Configurations

\begin{tabular}{|c|c|c|c|c|c|c|c|c|c|c|c|c|c|c|c|c|c|c|c|c|c|c|c|c|}
\hline \multirow{2}{*}{$\begin{array}{c}\text { Climate } \\
\text { Zone }\end{array}$} & \multicolumn{3}{|c|}{$\begin{array}{c}\text { Wall } \\
\text { R-Value }^{(a)}\end{array}$} & \multicolumn{3}{|c|}{$\begin{array}{c}\text { Ceiling } \\
\text { R-Value }\end{array}$} & \multicolumn{3}{|c|}{$\begin{array}{c}\text { Floor } \\
\text { R-Value }\end{array}$} & \multicolumn{3}{|c|}{$\begin{array}{l}\text { Basement Wall } \\
\text { R-Value }\end{array}$} & \multicolumn{3}{|c|}{$\begin{array}{c}\text { Slab } \\
\text { R-Value }\end{array}$} & \multicolumn{3}{|c|}{$\begin{array}{l}\text { Window } \\
\text { U-factor }\end{array}$} & \multicolumn{3}{|c|}{$\begin{array}{c}\text { Window } \\
\text { SHGC }\end{array}$} & \multicolumn{3}{|c|}{$\begin{array}{l}\text { Envelope } \\
\text { Leakage } \\
\text { (ACH50) }\end{array}$} \\
\hline & M & $\mathrm{H}$ & $\mathrm{L}$ & M & $\mathrm{H}$ & $\mathrm{L}$ & M & $\mathrm{H}$ & $\mathrm{L}$ & M & $\mathrm{H}$ & $\mathrm{L}$ & M & $\mathrm{H}$ & $\mathrm{L}$ & M & $\mathrm{H}$ & $\mathrm{L}$ & M & $\mathrm{H}$ & $\mathrm{L}$ & M & $\mathrm{H}$ & $\mathrm{L}$ \\
\hline 1 & 13 & 19 & 11 & 30 & 38 & 19 & 13 & 19 & 11 & 0 & 13 & 0 & 0 & 10 & 0 & 0.5 & 0.5 & 0.5 & 0.25 & 0.2 & 0.4 & 5 & 3 & 7 \\
\hline 2 & 13 & 19 & 11 & 38 & 49 & 30 & 13 & 19 & 11 & 0 & 13 & 0 & 0 & 10 & 0 & 0.4 & 0.4 & 0.4 & 0.25 & 0.2 & 0.4 & 5 & 3 & 7 \\
\hline 3 & 20 & $20+5$ & 13 & 38 & 49 & 30 & 19 & 30 & 13 & 13 & 19 & 0 & 10 & 15 & 0 & 0.35 & 0.35 & 0.4 & 0.25 & 0.2 & 0.4 & 3 & 1 & 5 \\
\hline 4 & 20 & $20+5$ & 13 & 49 & 60 & 38 & 19 & 30 & 13 & 13 & 19 & 0 & 10 & 15 & 0 & 0.35 & 0.25 & 0.4 & 0.4 & 0.4 & 0.4 & 3 & 1 & 5 \\
\hline $\begin{array}{l}5 \text { and } \\
4 \mathrm{C}\end{array}$ & 20 & $20+5$ & 13 & 49 & 60 & 38 & 30 & 38 & 19 & 19 & 21 & 13 & 10 & 15 & 0 & 0.32 & 0.25 & 0.4 & 0.4 & 0.4 & 0.4 & 3 & 1 & 5 \\
\hline 6 & $\begin{array}{c}20+ \\
5\end{array}$ & $\begin{array}{c}20+1 \\
0\end{array}$ & 20 & 49 & 60 & 38 & 30 & 38 & 19 & 19 & 21 & 13 & 10 & 15 & 0 & 0.32 & 0.25 & 0.4 & 0.4 & 0.4 & 0.4 & 3 & 1 & 5 \\
\hline 7 & $\begin{array}{c}20+ \\
5\end{array}$ & $\begin{array}{c}20+1 \\
0\end{array}$ & 20 & 49 & 60 & 38 & 38 & 49 & 30 & 19 & 21 & 13 & 10 & 15 & 0 & 0.32 & 0.25 & 0.4 & 0.4 & 0.4 & 0.4 & 3 & 1 & 5 \\
\hline 8 & $\begin{array}{c}20+ \\
5\end{array}$ & $\begin{array}{c}20+1 \\
0\end{array}$ & 20 & 49 & 60 & 38 & 38 & 49 & 30 & 19 & 21 & 13 & 10 & 15 & 0 & 0.32 & 0.25 & 0.4 & 0.4 & 0.4 & 0.4 & 3 & 1 & 5 \\
\hline
\end{tabular}

(a) Where there are two numbers, they represent cavity insulation and continuous (sheathing) insulation, respectively.

$\mathrm{M}=$ medium-level: prescriptive 2012 IECC requirement.

$\mathrm{H}=$ high-level: one level higher than the 2012 IECC requirement.

$\mathrm{L}=$ low-level: one level lower than the 2012 IECC requirement. 



\subsection{Results}

This section discusses the results of the analysis, ranges of Corresponding HERS Indexes for each climate zone and its volatility based on building characteristics. The volatility of the Corresponding HERS Indexes is presented for individual building characteristics and jointly for multiple building characteristics.

\subsection{Ranges of Corresponding HERS Indexes}

The range of the Corresponding HERS Indexes is observed to vary between different climate zones. This is expected due to the nature of the two metrics - HERS Index and the IECC Compliance Ratio and the difference in heating and cooling loads across climate zones. In order to better understand the volatility of the Corresponding HERS Index values to various building characteristics, this analysis considers its sensitivity to individual building characteristics as well as its joint volatility to multiple building characteristics considered together.

\subsubsection{Volatility of Corresponding HERS Index to Individual Building Characteristics}

As discussed in Section 3.4, each Corresponding HERS Index value is calculated based on a curve fit to three prototype buildings to establish a relationship between the HERS Index and IECC Compliance Ratio. The described methodology is applied to every combination of climate zone and building characteristic to identify the Corresponding HERS Index values used for this analysis. The Appendix shows graphics similar to Figure 3.1 above for every such calculation based on changes to single-home characteristics.

As a first-order assessment of the most important building characteristics, this analysis identifies the range of Corresponding HERS Index values occurring for each characteristic when all other building characteristics are fixed at a baseline level. The baseline levels are chosen in some cases to represent minimal code compliance (e.g., neutral orientation) and in other cases to represent the most common building configuration based on earlier PNNL analysis (e.g., crawlspace foundation). ${ }^{1}$ Table 4.1 shows these baseline characteristics.

The ranges of Corresponding HERS Index values computed for each building characteristic in isolation are shown in Figure 4.1 through Figure 4.15. Each figure represents a single climate zone. For each home characteristic, a plotted point (circle) shows the Corresponding HERS Index when that characteristic and all other characteristics are at the baseline values from Table 4.1. Whiskers extend outward from the circle to show the higher and/or lower Corresponding HERS Index values corresponding to changes in the given home characteristic.

\footnotetext{
${ }^{1}$ Based on national foundation shares, detailed by Mendon et al. 2013, crawlspace is the most dominant foundation type.
} 
Table 4.1. Baseline Characteristics Used in Assessing Volatility of Individual Building Characteristics

\begin{tabular}{ll}
\hline \multicolumn{1}{c}{ Building Characteristic } & \multicolumn{1}{c}{$\begin{array}{c}\text { Baseline Values Held Constant when Assessing Volatility of } \\
\text { Corresponding HERS Index Values }\end{array}$} \\
\hline $\begin{array}{l}\text { Gas/AC equipment efficiency } \\
\text { Heat pump equipment efficiency }\end{array}$ & $\begin{array}{l}\text { AFUE 78, SEER 13 } \\
\text { HSPF 7.7, SEER 13 }\end{array}$ \\
$\begin{array}{l}\text { Conditioned Floor Area (CFA) } \\
\text { Window-Floor Ratio (WFR) }\end{array}$ & $\begin{array}{l}16 \% \mathrm{ft}^{2} \\
\text { used }\end{array}$ \\
Appliances & Standard appliances (no ENERGY STAR) \\
Foundation type & Crawlspace \\
Number of stories (N_story) & 2 \\
Orientation & Neutral (glazing equally distributed) \\
\hline
\end{tabular}

The following observations can be drawn from these figures:

- In every climate, CFA is the most important characteristic. Corresponding HERS Index ranges are about 12 points in the southern regions and upwards of 15 points in the north. These ranges are comparable to the results obtained from analyses conducted by Fairey (2014). It seems clear any HERSbased code compliance path in any location would need to account for house size. Note, however, that the CFA dependence is not linear. Each CFA increase is approximately double the preceding CFA, but the change in Corresponding HERS Index between each adjacent pair is roughly the same. Consider Figure 4.1 as an example. At the baseline CFA of 2400, the Corresponding HERS Index is about 76. A rough doubling of the CFA to 5000 lowers the Corresponding HERS Index 6 points to about 70, while halving CFA to 1200 raises it 6 points to about 82. That pattern, suggesting a logarithmic relationship between house size and Corresponding HERS Index, is fairly consistent across the climate zones.

- In all climates except Zone 3, Marine (the California coast), Gas/AC equipment efficiency is the second most significant characteristic, showing 5- to 12-point ranges in the Corresponding HERS Index. This is not surprising, because equipment efficiency is directly accounted for in the HERS Index calculation but is ignored in the IECC Compliance Ratio. Heat pump efficiencies have a significant but smaller impact in southern climates, with that impact declining as climate gets colder. HVAC equipment is further discussed in Section 4.1.2.

- The third most significant building characteristic is Appliances. Allowing credit for ENERGY STAR appliances results in a change in the Corresponding HERS Index of 3 to 4 points in most locations, and 2 points in northernmost climates.

- Other than those mentioned above, no other characteristics stand out as consistently important across all climate zones.

- Somewhat surprisingly, the impact of the WFR is minor in most locations. Although the two metrics treat WFR differently and use different WFR values in their respective baseline homes, the minimal range of reasonable WFRs below the IECC's $15 \%$ baseline (12\% is the lowest evaluated here) may limit the effect of the HERS metric's crediting of low WFR. Similarly, the difference (15\% to $18 \%$ ) between the IECC's and HERS's baseline values is perhaps small compared to the large range of pos- 
sible WFR values at the high end (25\% analyzed here), limiting the magnitude of the WFR baseline impact.

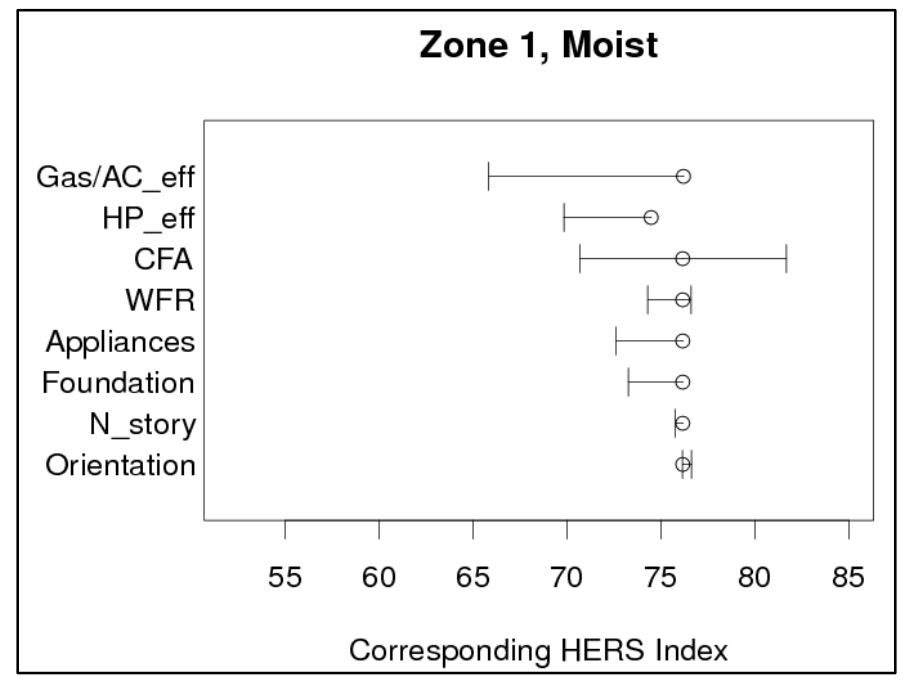

Figure 4.1. Volatility of Corresponding HERS Index to Individual Characteristics: Zone 1, Moist

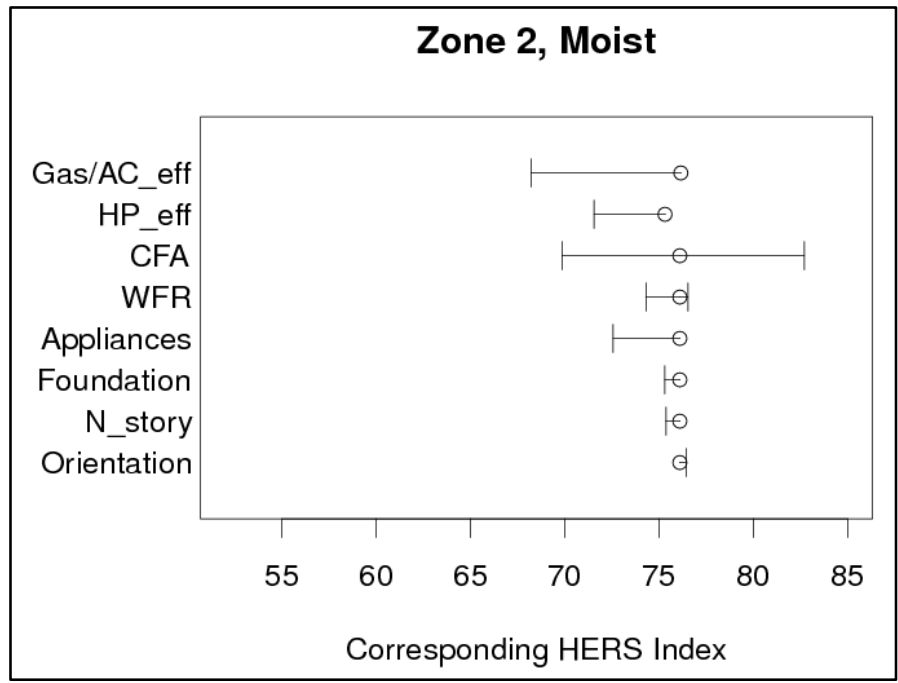

Figure 4.2. Volatility of Corresponding HERS Index to Individual Characteristics: Zone 2, Moist 


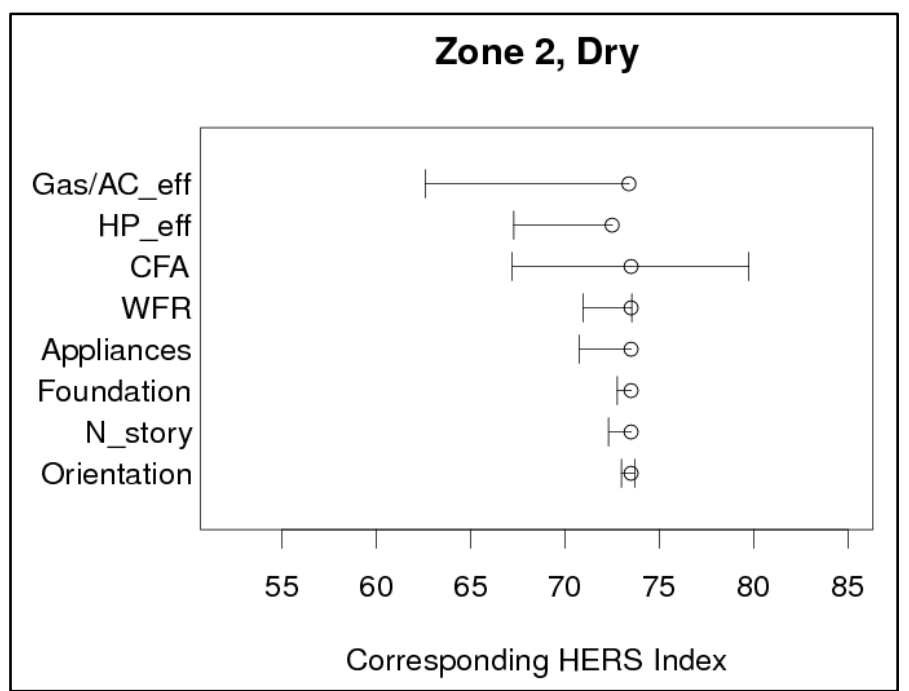

Figure 4.3. Volatility of Corresponding HERS Index to Individual Characteristics: Zone 2, Dry

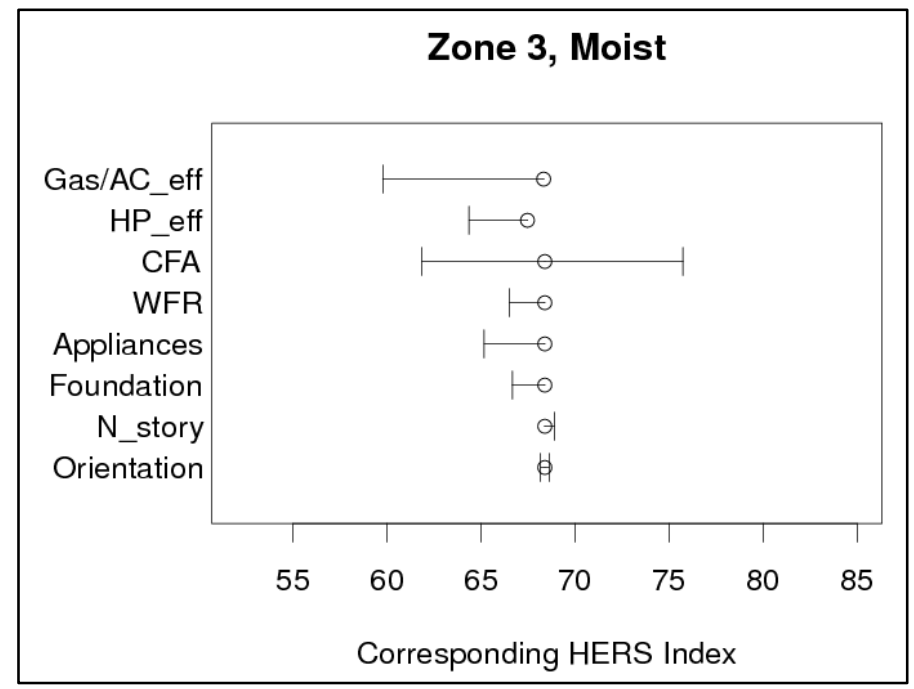

Figure 4.4. Volatility of Corresponding HERS Index to Individual Characteristics: Zone 3, Moist 


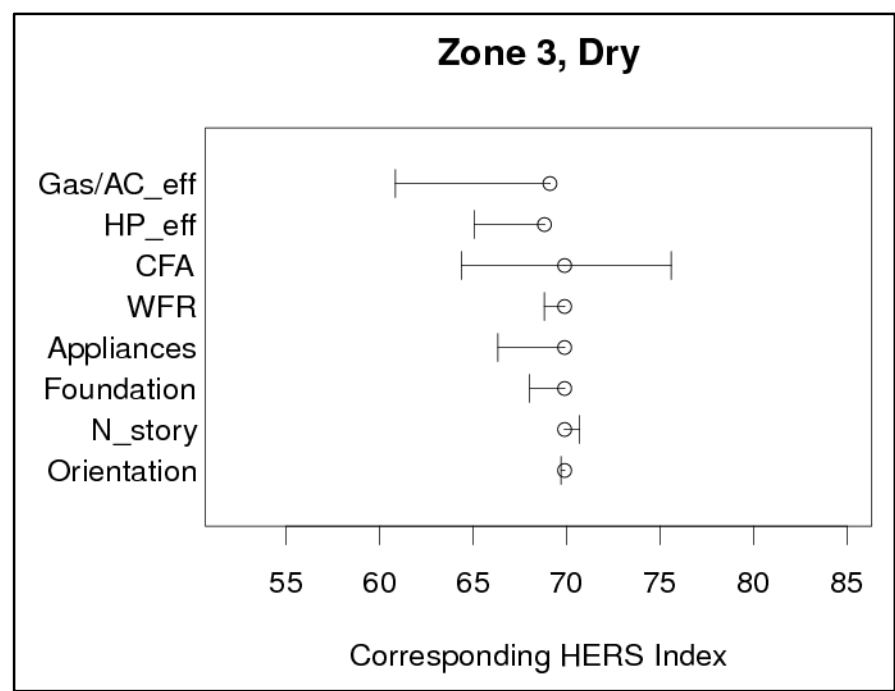

Figure 4.5. Volatility of Corresponding HERS Index to Individual Characteristics: Zone 3, Dry

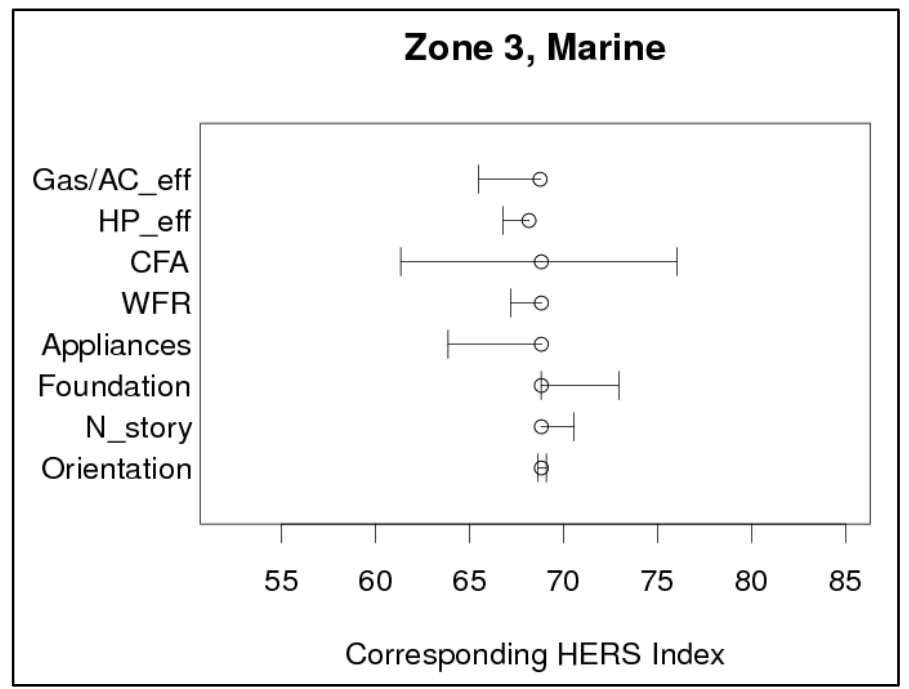

Figure 4.6. Volatility of Corresponding HERS Index to Individual Characteristics: Zone 3, Marine 


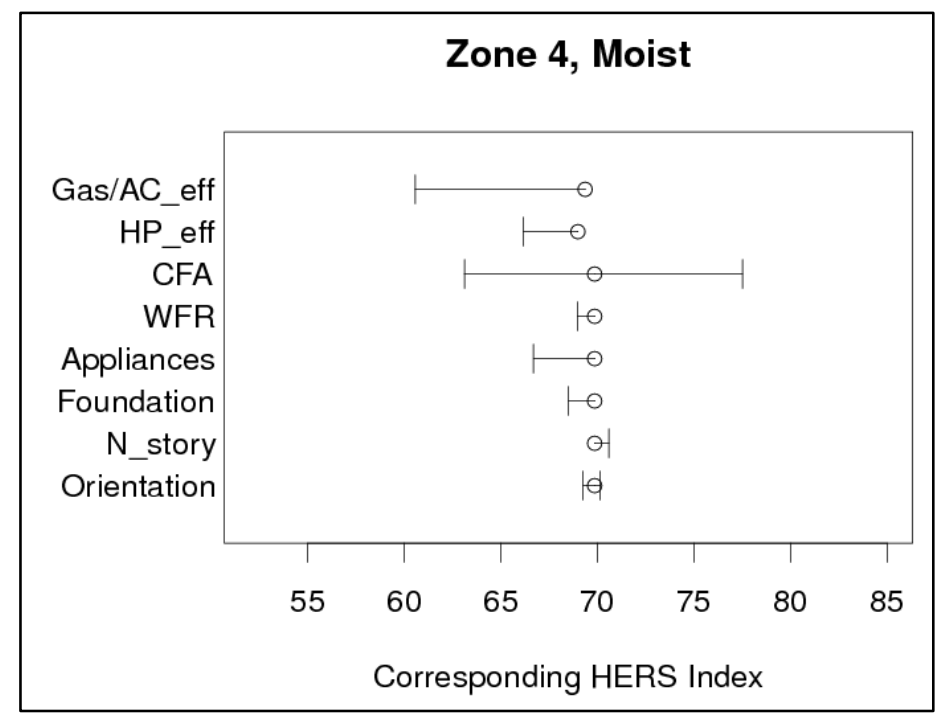

Figure 4.7. Volatility of Corresponding HERS Index to Individual Characteristics: Zone 4, Moist

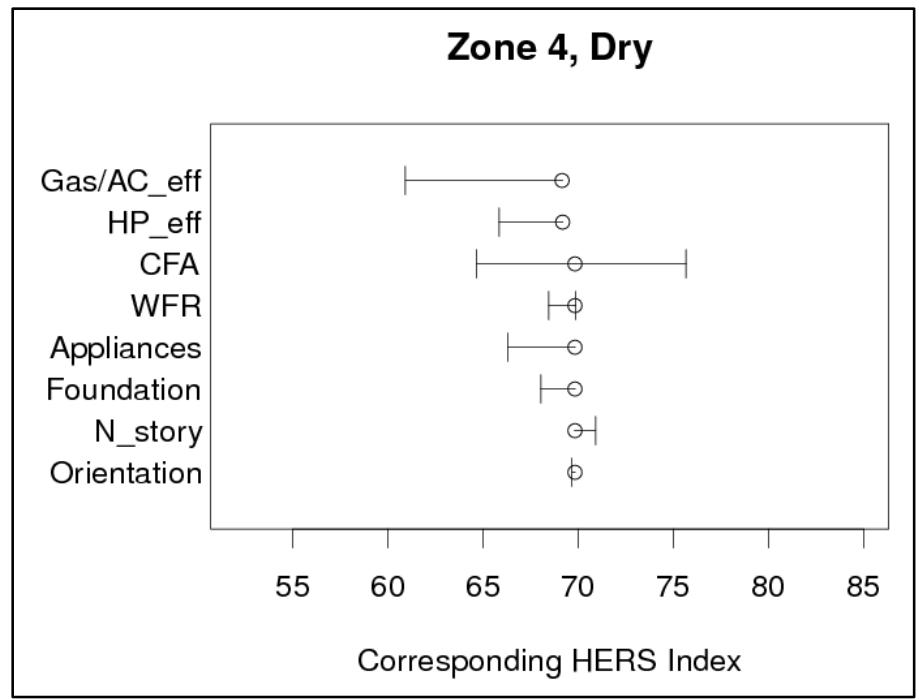

Figure 4.8. Volatility of Corresponding HERS Index to Individual Characteristics: Zone 4, Dry 


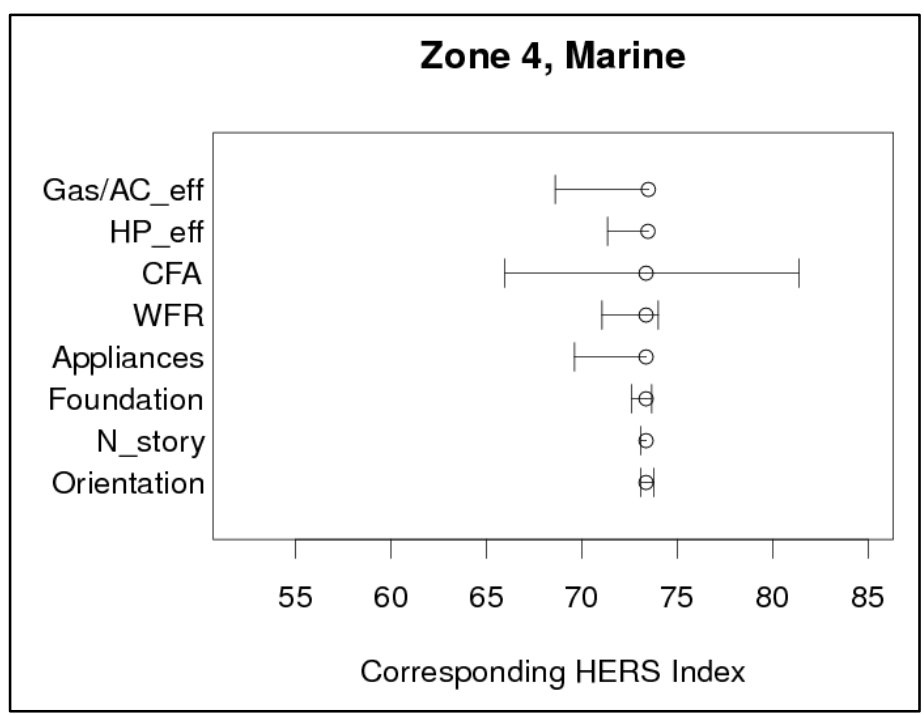

Figure 4.9. Volatility of Corresponding HERS Index to Individual Characteristics: Zone 4, Marine

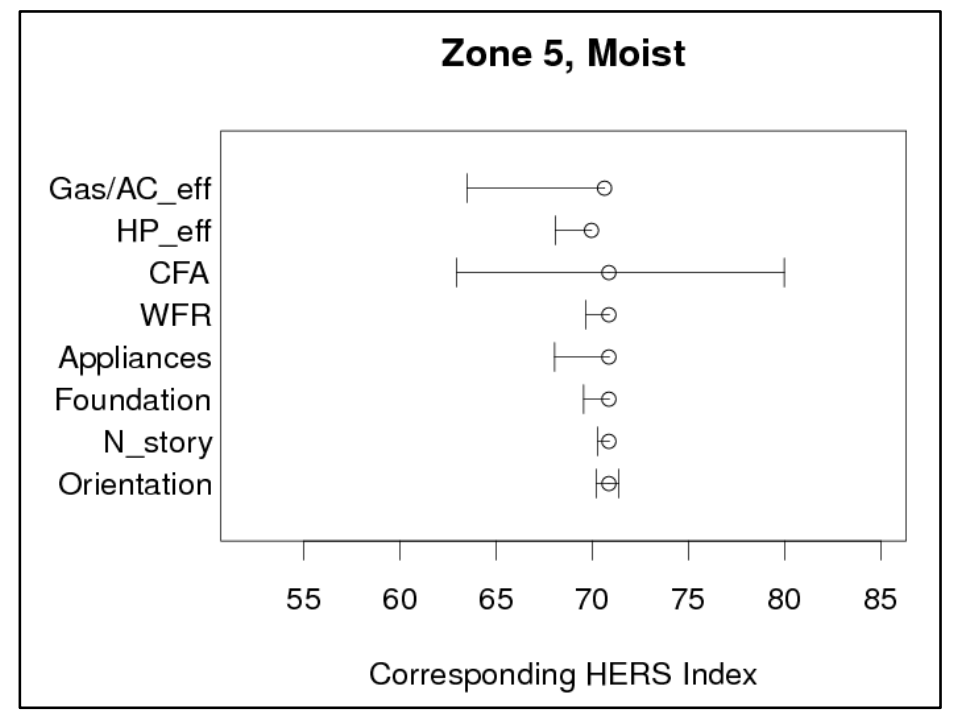

Figure 4.10. Volatility of Corresponding HERS Index to Individual Characteristics: Zone 5, Moist 


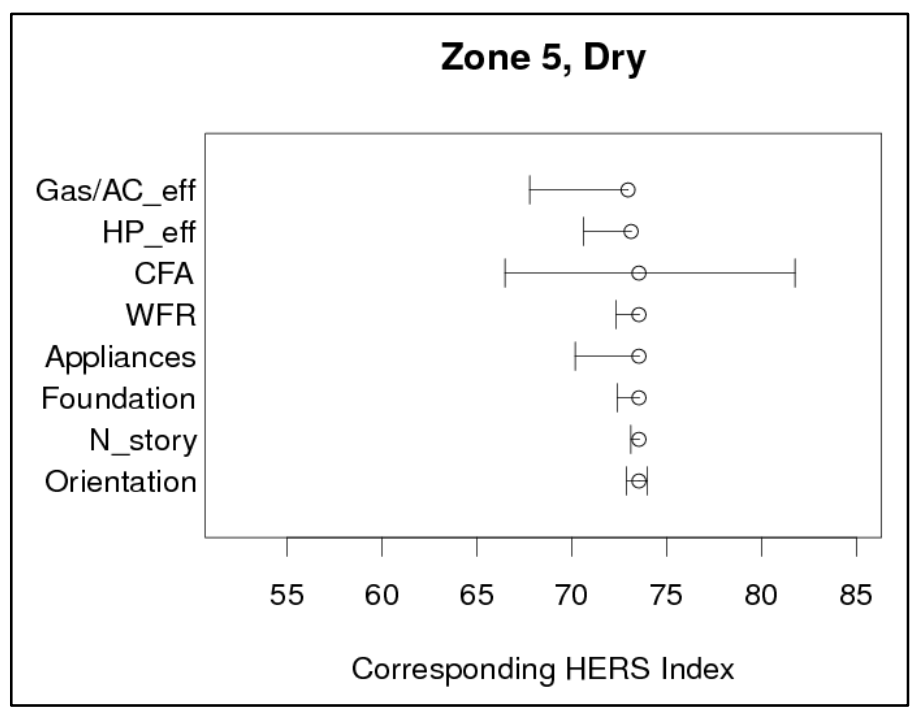

Figure 4.11. Volatility of Corresponding HERS Index to Individual Characteristics: Zone 5, Dry

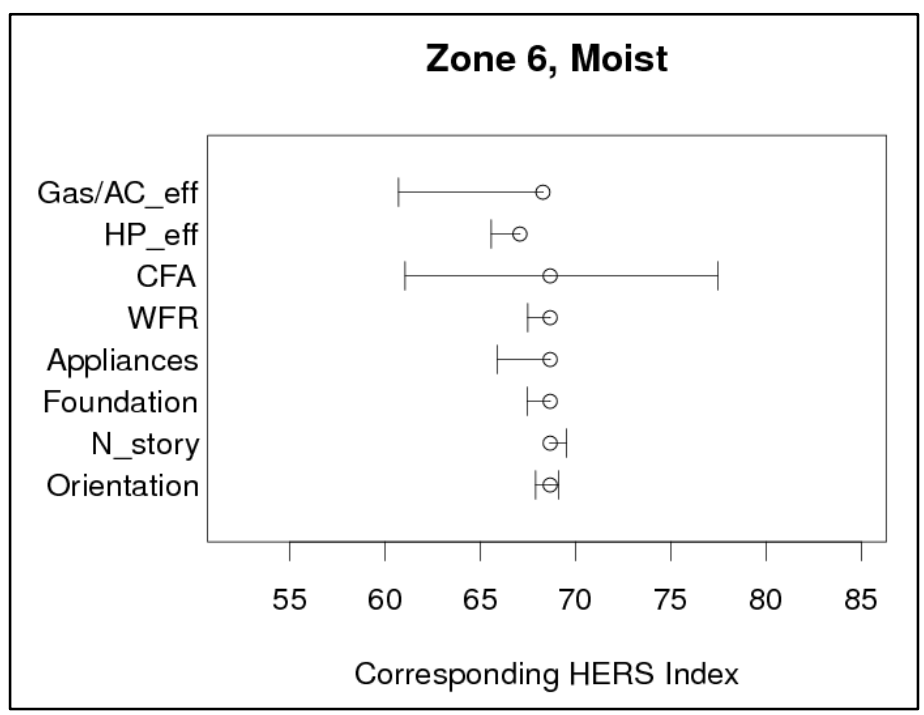

Figure 4.12. Volatility of Corresponding HERS Index to Individual Characteristics: Zone 6, Moist 


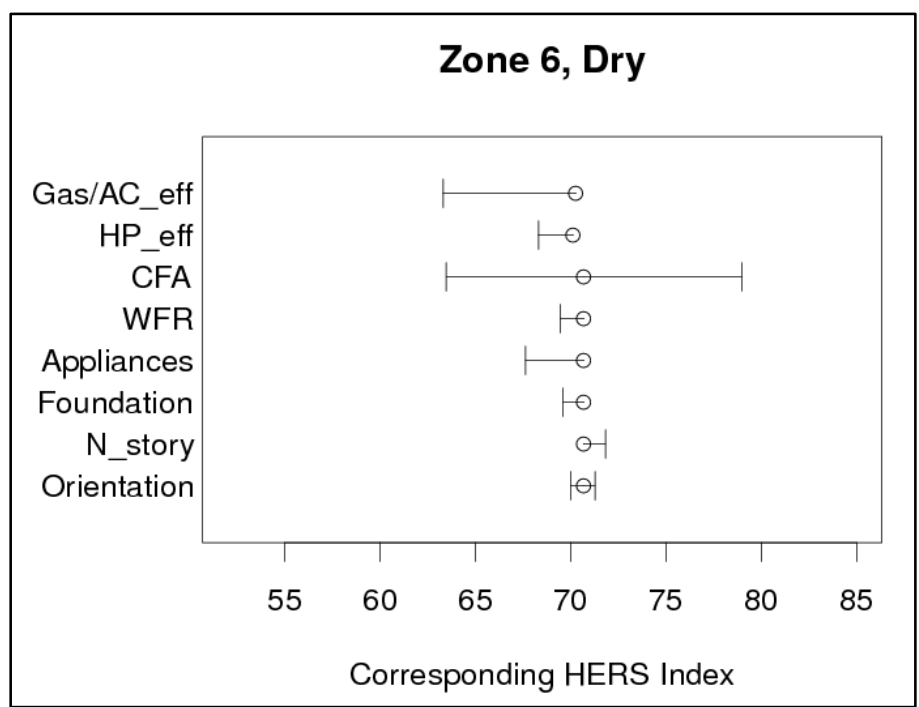

Figure 4.13. Volatility of Corresponding HERS Index to Individual Characteristics: Zone 6, Dry

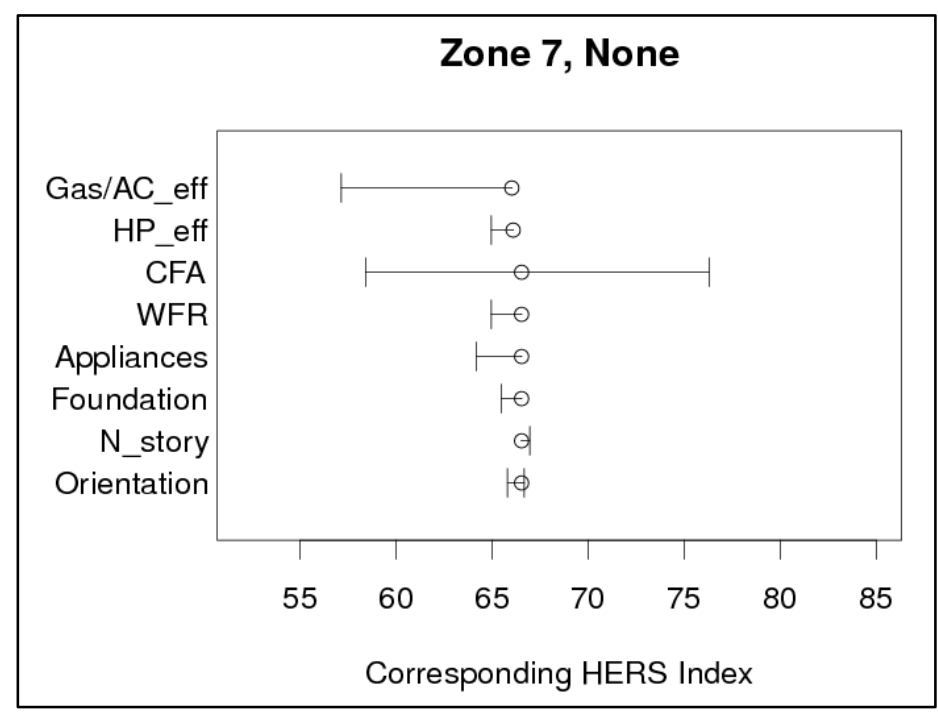

Figure 4.14. Volatility of Corresponding HERS Index to Individual Characteristics: Zone 7 


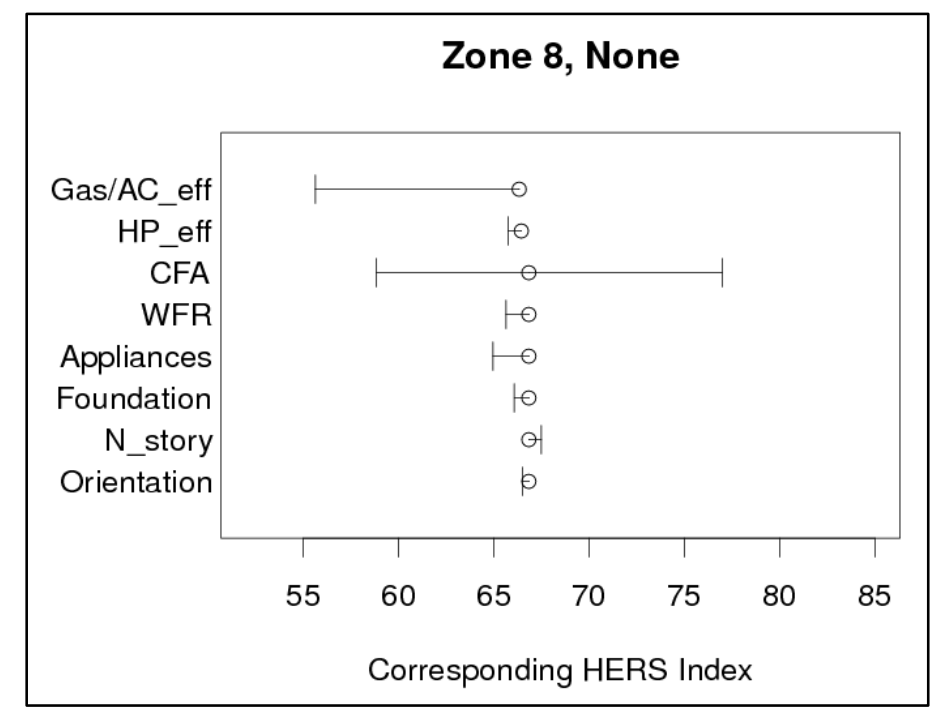

Figure 4.15. Volatility of Corresponding HERS Index to Individual Characteristics: Zone 8

\subsubsection{Volatility of Corresponding HERS Index to HVAC Efficiency}

Because HVAC efficiency is handled separately in designing the simulation experiment (see Section 2.3.7), it warrants a separate discussion. The impact of HVAC efficiency can be thought of as additive because, to a first order, HVAC efficiency simply applies an adjustment to the loads resulting from all other home characteristics. The change in Corresponding HERS Index values resulting from HVAC efficiency improvements must be added to the Corresponding HERS Indexes determined jointly for all other characteristics. Table 4.2 through Table 4.16 summarize the impact of HVAC efficiency on the Corresponding HERS Index.

Table 4.2. Impact of HVAC Efficiency on Corresponding HERS Index for Zone 1, Moist

\begin{tabular}{clc}
\hline \multirow{2}{*}{ System Type } & \multicolumn{1}{c}{ Efficiency Level } & $\begin{array}{c}\text { Change in Corre- } \\
\text { sponding HERS } \\
\text { Index }\end{array}$ \\
\hline \multirow{3}{*}{ Gas/AC Efficiency Level } & 0 \\
& Base (AFUE 78, SEER 13) & -2 \\
& High-efficiency 1 (AFUE 80, SEER 14) & -6 \\
& High-efficiency 2 (AFUE 80, SEER 16) & -10 \\
\hline \multirow{2}{*}{ Heat Pump Efficiency Level } & High-efficiency 3 (AFUE 80, SEER 20) & 0 \\
& Base (HSPF 7.7, SEER 13) & -4 \\
\hline
\end{tabular}


Table 4.3. Impact of HVAC Efficiency on Corresponding HERS Index for Zone 2, Moist

\begin{tabular}{clc}
\hline & \multicolumn{1}{c}{ Efficiency Level } & $\begin{array}{c}\text { Change in Corre- } \\
\text { sponding HERS } \\
\text { Index }\end{array}$ \\
\hline \multirow{3}{*}{ Gastem Type } & Base (AFUE 78, SEER 13) & 0 \\
& High-efficiency 1 (AFUE 80, SEER 14) & -2 \\
& High-efficiency 2 (AFUE 80, SEER 16) & -5 \\
& High-efficiency 3 (AFUE 80, SEER 20) & -8 \\
\hline \multirow{2}{*}{ Heat Pump Efficiency Level } & Base (HSPF 7.7, SEER 13) & 0 \\
& High-efficiency (HSPF 8.2, SEER 15) & -3 \\
\hline
\end{tabular}

Table 4.4. Impact of HVAC Efficiency on Corresponding HERS Index for Zone 2, Dry

\begin{tabular}{clc}
\hline System Type & \multicolumn{1}{c}{ Efficiency Level } & $\begin{array}{c}\text { Change in Corre- } \\
\text { sponding HERS } \\
\text { Index }\end{array}$ \\
\hline \multirow{3}{*}{ Gas/AC Efficiency Level } & Base (AFUE 78, SEER 13) & 0 \\
& High-efficiency 1 (AFUE 80, SEER 14) & -2 \\
& High-efficiency 2 (AFUE 80, SEER 16) & -6 \\
& High-efficiency 3 (AFUE 80, SEER 20) & -10 \\
\hline \multirow{2}{*}{ Heat Pump Efficiency Level } & Base (HSPF 7.7, SEER 13) & 0 \\
& High-efficiency (HSPF 8.2, SEER 15) & -5 \\
\hline
\end{tabular}

Table 4.5. Impact of HVAC Efficiency on Corresponding HERS Index for Zone 3, Moist

\begin{tabular}{clc}
\hline \multirow{2}{*}{ System Type } & \multicolumn{1}{c}{ Efficiency Level } & $\begin{array}{c}\text { Change in Corre- } \\
\text { sponding HERS } \\
\text { Index }\end{array}$ \\
\hline \multirow{3}{*}{ Gas/AC Efficiency Level } & Base (AFUE 78, SEER 13) & 0 \\
& High-efficiency 1 (AFUE 80, SEER 14) & -1 \\
& High-efficiency 2 (AFUE 94, SEER 16) & -6 \\
& High-efficiency 3 (AFUE 96, SEER 20) & -8 \\
\hline \multirow{2}{*}{ Heat Pump Efficiency Level } & Base (HSPF 7.7, SEER 13) & 0 \\
& High-efficiency (HSPF 9.0, SEER 15) & -3 \\
\hline
\end{tabular}


Table 4.6. Impact of HVAC Efficiency on Corresponding HERS Index for Zone 3, Dry

\begin{tabular}{clc}
\hline & \multicolumn{1}{c}{ Efficiency Level } & $\begin{array}{c}\text { Change in Corre- } \\
\text { sponding HERS } \\
\text { Index }\end{array}$ \\
\hline \multirow{3}{*}{ Gystem Type } & Base (AFUE 78, SEER 13) & 0 \\
& High-efficiency 1 (AFUE 80, SEER 14) & -1 \\
& High-efficiency 2 (AFUE 94, SEER 16) & -6 \\
& High-efficiency 3 (AFUE 96, SEER 20) & -8 \\
\hline \multirow{2}{*}{ Heat Pump Efficiency Level } & Base (HSPF 7.7, SEER 13) & 0 \\
& High-efficiency (HSPF 9.0, SEER 15) & -4 \\
\hline
\end{tabular}

Table 4.7. Impact of HVAC Efficiency on Corresponding HERS Index for Zone 3, Marine

\begin{tabular}{|c|c|c|}
\hline System Type & Efficiency Level & $\begin{array}{l}\text { Change in Corre- } \\
\text { sponding HERS } \\
\text { Index }\end{array}$ \\
\hline \multirow{4}{*}{ Gas/AC Efficiency Level } & Base (AFUE 78, SEER 13) & 0 \\
\hline & High-efficiency 1 (AFUE 80, SEER 14) & -1 \\
\hline & High-efficiency 2 (AFUE 94, SEER 16) & -3 \\
\hline & High-efficiency 3 (AFUE 96, SEER 20) & -4 \\
\hline \multirow{2}{*}{ Heat Pump Efficiency Level } & Base (HSPF 7.7, SEER 13) & 0 \\
\hline & High-efficiency (HSPF 9.0, SEER 15) & -1 \\
\hline
\end{tabular}

Table 4.8. Impact of HVAC Efficiency on Corresponding HERS Index for Zone 4, Moist

\begin{tabular}{|c|c|c|}
\hline System Type & Efficiency Level & $\begin{array}{l}\text { Change in Corre- } \\
\text { sponding HERS } \\
\text { Index }\end{array}$ \\
\hline \multirow{4}{*}{ Gas/AC Efficiency Level } & Base (AFUE 78, SEER 13) & 0 \\
\hline & High-efficiency 1 (AFUE 80, SEER 14) & -1 \\
\hline & High-efficiency 2 (AFUE 94, SEER 16) & -6 \\
\hline & High-efficiency 3 (AFUE 96, SEER 20) & -8 \\
\hline \multirow{2}{*}{ Heat Pump Efficiency Level } & Base (HSPF 7.7, SEER 13) & 0 \\
\hline & High-efficiency (HSPF 9.0, SEER 15) & -3 \\
\hline
\end{tabular}


Table 4.9. Impact of HVAC Efficiency on Corresponding HERS Index for Zone 4, Dry

\begin{tabular}{clc}
\hline & \multicolumn{1}{c}{ Efficiency Level } & $\begin{array}{c}\text { Change in Corre- } \\
\text { sponding HERS } \\
\text { Index }\end{array}$ \\
\hline \multirow{3}{*}{ Gystem Type } & Base (AFUE 78, SEER 13) & 0 \\
& High-efficiency 1 (AFUE 80, SEER 14) & -1 \\
& High-efficiency 2 (AFUE 94, SEER 16) & -6 \\
& High-efficiency 3 (AFUE 96, SEER 20) & -8 \\
\hline \multirow{2}{*}{ Heat Pump Efficiency Level } & Base (HSPF 7.7, SEER 13) & 0 \\
& High-efficiency (HSPF 9.0, SEER 15) & -3 \\
\hline
\end{tabular}

Table 4.10. Impact of HVAC Efficiency on Corresponding HERS Index for Zone 4, Marine

\begin{tabular}{clc}
\hline & \multicolumn{1}{c}{ Efficiency Level } & $\begin{array}{c}\text { Change in Corre- } \\
\text { sponding HERS } \\
\text { Index }\end{array}$ \\
\hline \multirow{5}{*}{ Gystem Type } & Base (AFUE 78, SEER 13) & 0 \\
& High-efficiency 1 (AFUE 80, SEER 14) & -3 \\
& High-efficiency 2 (AFUE 94, SEER 16) & -4 \\
& High-efficiency 3 (AFUE 96, SEER 20) & -4 \\
\hline \multirow{2}{*}{ Heat Pump Efficiency Level } & Base (HSPF 7.7, SEER 13) & 0 \\
& High-efficiency (HSPF 9.0, SEER 15) & -2 \\
\hline
\end{tabular}

Table 4.11. Impact of HVAC Efficiency on Corresponding HERS Index for Zone 5, Moist

\begin{tabular}{clc}
\hline & \multicolumn{1}{c}{ Efficiency Level } & $\begin{array}{c}\text { Change in Corre- } \\
\text { sponding HERS } \\
\text { Index }\end{array}$ \\
\hline \multirow{3}{*}{ Gastem Type } & Base (AFUE 78, SEER 13) & 0 \\
& High-efficiency 1 (AFUE 80, SEER 13) & -5 \\
& High-efficiency 2 (AFUE 94, SEER 13) & -7 \\
& High-efficiency 3 (AFUE 96, SEER 13) & -8 \\
\hline \multirow{2}{*}{ Heat Pump Efficiency Level } & Base (HSPF 7.7, SEER 13) & 0 \\
& High-efficiency (HSPF 9.0, SEER 14) & -2 \\
\hline
\end{tabular}


Table 4.12. Impact of HVAC Efficiency on Corresponding HERS Index for Zone 5, Dry

\begin{tabular}{|c|c|c|}
\hline System Type & Efficiency Level & $\begin{array}{l}\text { Change in Corre- } \\
\text { sponding HERS } \\
\text { Index }\end{array}$ \\
\hline \multirow{4}{*}{ Gas/AC Efficiency Level } & Base (AFUE 78, SEER 13) & 0 \\
\hline & High-efficiency 1 (AFUE 80, SEER 13) & -4 \\
\hline & High-efficiency 2 (AFUE 94, SEER 13) & -5 \\
\hline & High-efficiency 3 (AFUE 96, SEER 13) & -5 \\
\hline \multirow{2}{*}{ Heat Pump Efficiency Level } & Base (HSPF 7.7, SEER 13) & 0 \\
\hline & High-efficiency (HSPF 9.0, SEER 14) & -2 \\
\hline
\end{tabular}

Table 4.13. Impact of HVAC Efficiency on Corresponding HERS Index for Zone 6, Moist

\begin{tabular}{|c|c|c|}
\hline System Type & Efficiency Level & $\begin{array}{l}\text { Change in Corre- } \\
\text { sponding HERS } \\
\text { Index }\end{array}$ \\
\hline \multirow{4}{*}{ Gas/AC Efficiency Level } & Base (AFUE 78, SEER 13) & 0 \\
\hline & High-efficiency 1 (AFUE 80, SEER 13) & -5 \\
\hline & High-efficiency 2 (AFUE 94, SEER 13) & -7 \\
\hline & High-efficiency 3 (AFUE 96, SEER 13) & -7 \\
\hline \multirow{2}{*}{ Heat Pump Efficiency Level } & Base (HSPF 7.7, SEER 13) & 0 \\
\hline & High-efficiency (HSPF 9.0, SEER 14) & -1 \\
\hline
\end{tabular}

Table 4.14. Impact of HVAC Efficiency on Corresponding HERS Index for Zone 6, Dry

\begin{tabular}{|c|c|c|}
\hline System Type & Efficiency Level & $\begin{array}{c}\text { Change in Corre- } \\
\text { sponding HERS } \\
\text { Index }\end{array}$ \\
\hline \multirow{4}{*}{ Gas/AC Efficiency Level } & Base (AFUE 78, SEER 13) & 0 \\
\hline & High-efficiency 1 (AFUE 80, SEER 13) & -5 \\
\hline & High-efficiency 2 (AFUE 94, SEER 13) & -6 \\
\hline & High-efficiency 3 (AFUE 96, SEER 13) & -7 \\
\hline \multirow{2}{*}{ Heat Pump Efficiency Level } & Base (HSPF 7.7, SEER 13) & 0 \\
\hline & High-efficiency (HSPF 9.0, SEER 14) & -2 \\
\hline
\end{tabular}


Table 4.15. Impact of HVAC Efficiency on Corresponding HERS Index for Zone 7

\begin{tabular}{|c|c|c|}
\hline System Type & Efficiency Level & $\begin{array}{c}\text { Change in Corre- } \\
\text { sponding HERS } \\
\text { Index }\end{array}$ \\
\hline \multirow{4}{*}{ Gas/AC Efficiency Level } & Base (AFUE 78, SEER 13) & 0 \\
\hline & High-efficiency 1 (AFUE 80, SEER 13) & -6 \\
\hline & High-efficiency 2 (AFUE 94, SEER 13) & -8 \\
\hline & High-efficiency 3 (AFUE 96, SEER 13) & -9 \\
\hline \multirow{2}{*}{ Heat Pump Efficiency Level } & Base (HSPF 7.7, SEER 13) & 0 \\
\hline & High-efficiency (HSPF 9.0, SEER 14) & -1 \\
\hline
\end{tabular}

Table 4.16. Impact of HVAC Efficiency on Corresponding HERS Index for Zone 8

\begin{tabular}{clc}
\hline System Type & \multicolumn{1}{c}{ Efficiency Level } & $\begin{array}{c}\text { Change in Corre- } \\
\text { sponding HERS } \\
\text { Index }\end{array}$ \\
\hline \multirow{3}{*}{ Gas/AC Efficiency Level } & Base (AFUE 78, SEER 13) & 0 \\
& High-efficiency 1 (AFUE 80, SEER 13) & -7 \\
& High-efficiency 2 (AFUE 94, SEER 13) & -9 \\
& High-efficiency 3 (AFUE 96, SEER 13) & -10 \\
\hline \multirow{2}{*}{ Heat Pump Efficiency Level } & Base (HSPF 7.7, SEER 13) & 0 \\
& High-efficiency (HSPF 9.0, SEER 14) & 0 \\
\hline
\end{tabular}

\subsubsection{Joint Volatility of Corresponding HERS Index across Multiple Building Characteristics}

The previous section shows that the Corresponding HERS Index is quite volatile with respect to CFA and HVAC efficiency and, depending on the climate zone, several other characteristics may be significant as well. As alluded to in Section 1.0, policy makers interested in crafting (or amending) a HERS-based compliance path might need to understand how multiple home characteristics affect the correspondence between the HERS Index and the IECC Compliance Ratio. Understanding the volatility across multiple characteristics could help in explaining real-world differences in code compliance between the 2015 IECC's ERI path and its Performance Path, or could inform the development of custom compliance paths if such were contemplated. A HERS-based compliance path might be structured as a decision tree, where the required HERS rating depends on nested questions about the home under consideration. This analysis has sought to construct model decision trees to inform policy makers of the important variables and assist them in evaluating and/or structuring HERS-based compliance paths.

Analyzing the volatility of the Corresponding HERS Index to multiple building characteristics simultaneously is an unwieldy exercise if all of the building characteristics evaluated in this report are included. Fairey (2014) analyzed the volatility of the HERS Index to CFA, number of bedrooms, and number of stories by varying each characteristic in isolation while keeping the others constant. A usable HERSbased IECC compliance path will thus need to be simple and straightforward to implement, which probably disqualifies any system that keys on more than a small number of characteristics. The 2015 ERI path, 
for example, keys on no building characteristics, making it easy to express—a single number for each zone-at the expense of not being sensitive to changes in any building characteristics.

The approach used to develop the trees presented in Table 4.17 through Table 4.31 was based on a recursive partitioning scheme for creating classification and regression trees available in the " $\mathrm{R}$ " system for statistical computing and graphics. ${ }^{1}$ Details about the methodology can be found in Therneau and Atkinson (2013). However, note that neither the statistical strengths of the technique, nor the specific summary statistics (deviance, etc.) of the partitions created are relevant here because the data under consideration are not random variables. The technique is merely used as a practical methodology for identifying the building characteristics that most effectively narrow the ranges of the Corresponding HERS Index values with the fewest number of divisions in this set of simulated energy-performance data.

The decision trees presented below have two columns at the far right showing the minimum and maximum Corresponding HERS Index values within the limits of the building characteristics accounted for in the tree to the left. The leftmost node, labeled "None," represents the Corresponding HERS Index range for the entire simulation data set for the climate zone (i.e., accounting for none of the building characteristics). That node spans the vertical extent of the tree, so finding the minimum and maximum Corresponding HERS Index values involves reading the top left (Min) and bottom right (Max) values in the table. The same pattern applies at deeper levels of the tree as building characteristics are accounted for.

Consider as an example Table 4.17, which shows the decision tree for Climate Zone 1, Moist. Accounting for none of the building characteristics results in a range of Corresponding HERS Indexes from 57 to 82 . Segregating the very large homes (5000 $\left.\mathrm{ft}^{2} \mathrm{CFA}\right)$ from the small and average homes results in two ranges: $57-71$ for the large homes and 63-82 for the small-to-average homes. Further subdividing the $5000 \mathrm{ft}^{2}$ subset by foundation type breaks the 57-71 range into sub-ranges of 57-69 and 65-71.

Note that because HVAC efficiency was not included in the full combinatorial simulation experiment (see Section 2.3.7), its impact is not included in these decision trees. The relative impacts of high HVAC efficiency shown in Section 4.1.1 would need to be superimposed on these results to obtain meaningful absolute Corresponding HERS Index values. To a first order, a change in HVAC efficiency would affect both ends of a range of values, so the range itself would be similar regardless of HVAC efficiency. For example, considering Table 4.17 again, a home with a SEER 20 air-conditioner and a gas furnace with an AFUE of 80 and accounting for none of the building characteristics would result in a range of Corresponding HERS Indexes from 47 to 72 due to an impact of 10 points as shown in Table 4.2.

The decision trees gleaned from this analysis and shown in Table 4.17 through Table 4.31 show the range of Corresponding HERS Index values that remain after accounting for the most significant building characteristics at each level of the decision tree. These trees can be used either to evaluate an existing HERS-based compliance path or to assist in developing a custom path. As an example of the former, the 2015 IECC's ERI path gives a single ERI threshold for each of the code's eight numbered climate zones. Those thresholds are all in the low- to mid-50s, values that are close to, if a little lower (more stringent) than, the smallest numbers in Table 4.17 through Table 4.31. However, the tables assume no highefficiency equipment will be considered. If adjustments for high-efficiency equipment (Table 4.2 through Table 4.16) are made to the lowest values in the decision trees, those values become a bit lower than the

\footnotetext{
${ }^{1}$ http://www.r-project.org/
} 
2015 IECC's ERI thresholds. Thus, one can conclude that the ERIs are generally very near the conservative end of possible values, but not quite so low as to always guarantee that a home complying via the ERI path would also comply via the Performance Path.

Using the decision trees to identify appropriate Corresponding HERS Index values as custom, local thresholds would require a subjective decision by policy makers. For example, single values might be chosen from the low end of each range (after further adjusting for high HVAC efficiency) remaining after accounting for one or two important characteristics. Also, because this analysis evaluates only a few points along the range of each building characteristic, there may be a need for interpolation and/or extrapolation in some cases.

The following observations can be drawn from the results:

- In general, the decision trees are simpler in the northern climate zones. This comports with the individual-characteristic observations in the previous section and is expected because the southern climates involve a mix of heating and cooling considerations, whereas the far northern climates are dominated by heating.

- In all climate zones, the most important building characteristic — and the first to account for in the decision tree-is CFA. In most cases, small homes are separated from average and large homes, though in a few cases (Zone 1, Moist; Zone 2, Moist; Zone 3, Marine) small and average homes are paired, with large homes treated separately.

- The second-level decision varies depending on the situation, but is usually either a further division of CFA or an accounting for appliances.

- Further divisions, if they show up at all, involve foundation type or WFR. Number of stories appears only once (Zone 1, Moist) and glazing orientation is never a useful discriminator.

- Even after accounting for the three or four most significant home characteristics, Corresponding HERS Index ranges often remain somewhat large_-as much as nine HERS points and often five or more.

- The 2015 IECC’s ERI thresholds are very similar to the lowest Corresponding HERS Indexes identified in this analysis. 
Table 4.17. Corresponding HERS Index Ranges for Zone 1, Moist

\begin{tabular}{|c|c|c|c|c|c|c|}
\hline \multirow{2}{*}{\multicolumn{5}{|c|}{ Characteristics Accounted For }} & \multicolumn{2}{|c|}{$\begin{array}{l}\text { Corresponding } \\
\text { HERS Index } \\
\text { Range }\end{array}$} \\
\hline & & & & & Min. & Max. \\
\hline \multirow{11}{*}{ None } & \multirow{3}{*}{$\mathrm{CFA}=5000$} & \multirow{2}{*}{ Slab or Basement } & \multicolumn{2}{|l|}{1 Story } & 57 & 68 \\
\hline & & & \multicolumn{2}{|l|}{2 Story } & 63 & 69 \\
\hline & & Crawlspace & & & 65 & 71 \\
\hline & \multirow{8}{*}{$\begin{array}{l}\text { CFA }=1200 \text { or } \\
2400\end{array}$} & \multirow{4}{*}{$\mathrm{CFA}=2400$} & \multirow{2}{*}{$\begin{array}{l}\text { ENERGY STAR } \\
\text { Appliances }\end{array}$} & $\begin{array}{l}\text { Slab or Base- } \\
\text { ment }\end{array}$ & 63 & 71 \\
\hline & & & & Crawlspace & 70 & 73 \\
\hline & & & \multirow{2}{*}{$\begin{array}{l}\text { Standard Appli- } \\
\text { ances }\end{array}$} & Basement & 66 & 74 \\
\hline & & & & $\begin{array}{l}\text { Crawlspace or } \\
\text { Slab }\end{array}$ & 71 & 77 \\
\hline & & \multirow{4}{*}{$\mathrm{CFA}=1200$} & \multirow{2}{*}{$\begin{array}{l}\text { ENERGY STAR } \\
\text { Appliances }\end{array}$} & Basement & 66 & 74 \\
\hline & & & & $\begin{array}{l}\text { Crawlspace or } \\
\text { Slab }\end{array}$ & 72 & 77 \\
\hline & & & \multirow{2}{*}{$\begin{array}{l}\text { Standard Appli- } \\
\text { ances }\end{array}$} & Basement & 71 & 78 \\
\hline & & & & $\begin{array}{l}\text { Crawlspace or } \\
\text { Slab }\end{array}$ & 78 & 82 \\
\hline
\end{tabular}

Table 4.18. Corresponding HERS Index Ranges for Zone 2, Moist

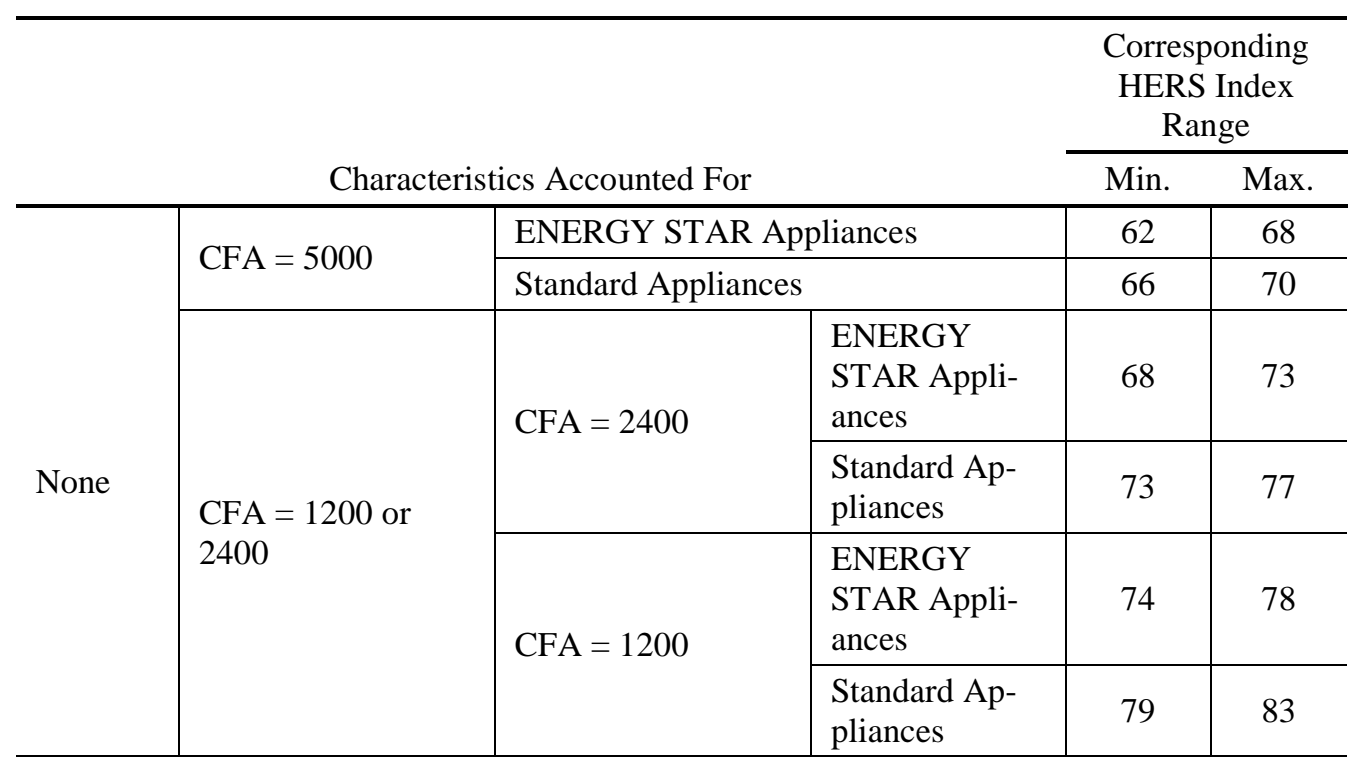


Table 4.19. Corresponding HERS Index Ranges for Zone 2, Dry

\begin{tabular}{|c|c|c|c|c|c|}
\hline & & & & $\begin{array}{r}\text { Corre } \\
\text { HEP } \\
\text { R }\end{array}$ & $\begin{array}{l}\text { nding } \\
\text { ndex } \\
\text { ge }\end{array}$ \\
\hline & & ristics Accoun & & Min. & Max. \\
\hline & & CEA - 5000 & WFR $=0.12$ & 59 & 66 \\
\hline & & CFA -5000 & WFR $=0.16$ or 0.25 & 61 & 68 \\
\hline None & 5000 & $\mathrm{CFA}=2400$ & $\begin{array}{l}\text { ENERGY STAR } \\
\text { Appliances }\end{array}$ & 65 & 71 \\
\hline & & & Standard Appliances & 68 & 74 \\
\hline & $C 54-1100$ & ENERGY ST & liances & 71 & 76 \\
\hline & $C F A=1200$ & Standard ApI & & 76 & 80 \\
\hline
\end{tabular}

Table 4.20. Corresponding HERS Index Ranges for Zone 3, Moist

\begin{tabular}{|c|c|c|c|c|c|}
\hline & & & & $\begin{array}{r}\text { Corre } \\
\text { HER } \\
\mathrm{R}\end{array}$ & $\begin{array}{l}\text { onding } \\
\text { Index } \\
\text { ge }\end{array}$ \\
\hline & Cha & istics Accoun & & Min. & Max. \\
\hline & & $\mathrm{CFA}=5000$ & $\begin{array}{l}\text { ENERGY STAR } \\
\text { Appliances }\end{array}$ & 55 & 61 \\
\hline & $\mathrm{CFA}=2400$ or & & Standard Appliances & 57 & 63 \\
\hline None & 5000 & $\mathrm{CFA}=2400$ & $\begin{array}{l}\text { ENERGY STAR } \\
\text { Appliances }\end{array}$ & 61 & 66 \\
\hline & & & Standard Appliances & 65 & 69 \\
\hline & $C Г-1200$ & ENERGY ST & liances & 67 & 72 \\
\hline & $C F A=1200$ & Standard App & & 72 & 77 \\
\hline
\end{tabular}

Table 4.21. Corresponding HERS Index Ranges for Zone 3, Dry

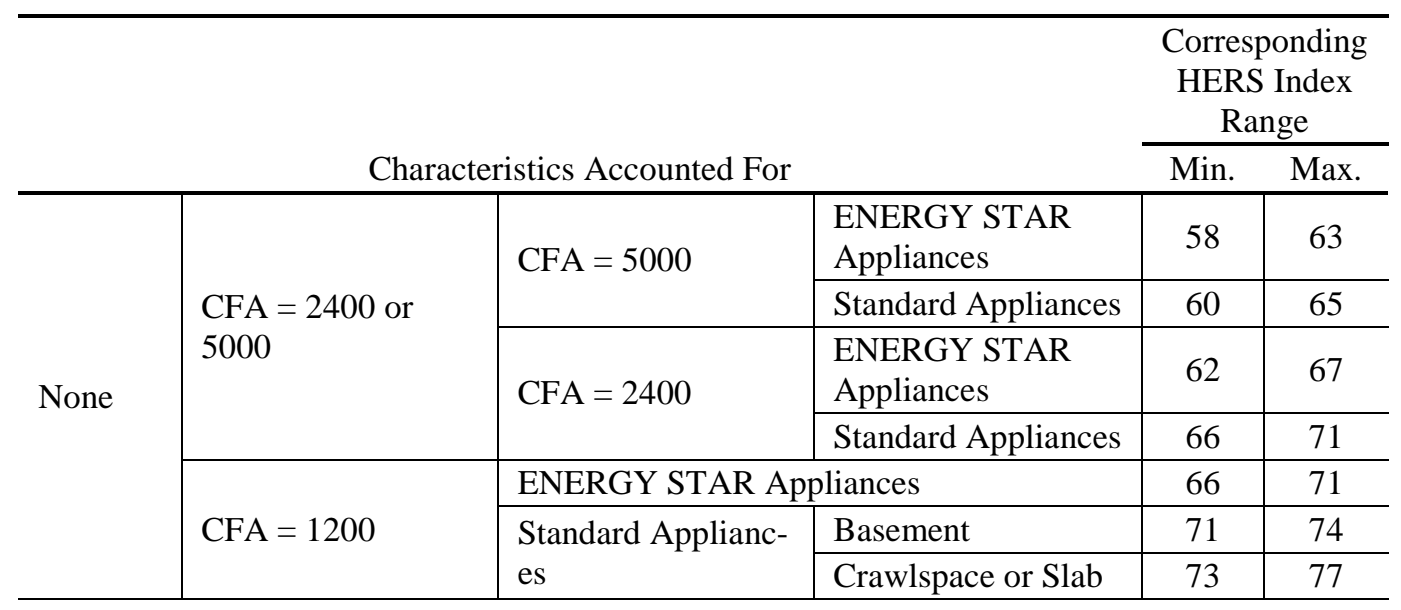


Table 4.22. Corresponding HERS Index Ranges for Zone 3, Marine

\begin{tabular}{|c|c|c|c|c|c|c|}
\hline & & & & & \multicolumn{2}{|c|}{$\begin{array}{l}\text { Correspond- } \\
\text { ing HERS } \\
\text { Index Range }\end{array}$} \\
\hline \multicolumn{5}{|c|}{ Characteristics Accounted For } & Min. & Max. \\
\hline \multirow{9}{*}{ None } & \multirow{3}{*}{$\mathrm{CFA}=5000$} & \multirow{2}{*}{ Crawlspace or Slab } & \multicolumn{2}{|c|}{ ENERGY STAR Appliances } & 56 & 60 \\
\hline & & & \multicolumn{2}{|c|}{ Standard Appliances } & 59 & 63 \\
\hline & & \multicolumn{3}{|l|}{ Basement } & 60 & 68 \\
\hline & \multirow{6}{*}{$\begin{array}{l}\text { CFA }=1200 \text { or } \\
2400\end{array}$} & \multirow{3}{*}{$\begin{array}{l}\text { ENERGY STAR } \\
\text { Appliances }\end{array}$} & \multirow{2}{*}{$\mathrm{CFA}=2400$} & Crawlspace or Slab & 62 & 66 \\
\hline & & & & Basement & 66 & 70 \\
\hline & & & \multicolumn{2}{|l|}{$\mathrm{CFA}=1200$} & 68 & 74 \\
\hline & & \multirow{3}{*}{$\begin{array}{l}\text { Standard Applianc- } \\
\text { es }\end{array}$} & \multirow{2}{*}{$\mathrm{CFA}=2400$} & Crawlspace or Slab & 67 & 71 \\
\hline & & & & Basement & 72 & 76 \\
\hline & & & \multicolumn{2}{|l|}{$\mathrm{CFA}=1200$} & 75 & 82 \\
\hline
\end{tabular}

Table 4.23. Corresponding HERS Index Ranges for Zone 4, Moist

\begin{tabular}{|c|c|c|c|c|c|}
\hline & & & & \multicolumn{2}{|c|}{$\begin{array}{c}\text { Corresponding } \\
\text { HERS Index } \\
\text { Range } \\
\end{array}$} \\
\hline \multicolumn{4}{|c|}{ Characteristics Accounted For } & Min. & Max. \\
\hline \multirow{5}{*}{ None } & \multirow{3}{*}{$\begin{array}{l}\text { CFA }=2400 \text { or } \\
5000\end{array}$} & \multicolumn{2}{|l|}{$\mathrm{CFA}=5000$} & 56 & 64 \\
\hline & & \multirow[t]{2}{*}{$\mathrm{CFA}=2400$} & $\begin{array}{l}\text { ENERGY STAR } \\
\text { Appliances }\end{array}$ & 63 & 68 \\
\hline & & & Standard Appliances & 66 & 71 \\
\hline & \multirow{2}{*}{$\mathrm{CFA}=1200$} & \multicolumn{2}{|c|}{ ENERGY STAR Appliances } & 70 & 74 \\
\hline & & \multicolumn{2}{|c|}{ Standard Appliances } & 75 & 79 \\
\hline
\end{tabular}

Table 4.24. Corresponding HERS Index Ranges for Zone 4, Dry

\begin{tabular}{|c|c|c|c|c|c|c|}
\hline & & & & & \multicolumn{2}{|c|}{$\begin{array}{l}\text { Corresponding } \\
\text { HERS Index } \\
\text { Range }\end{array}$} \\
\hline \multicolumn{5}{|c|}{ Characteristics Accounted For } & Min. & Max. \\
\hline \multirow{7}{*}{ None } & \multirow{5}{*}{$\begin{array}{l}\text { CFA }=2400 \text { or } \\
5000\end{array}$} & \multirow{3}{*}{$\mathrm{CFA}=5000$} & \multirow[b]{2}{*}{ Slab or Basement } & $\mathrm{WFR}=0.12$ & 56 & 63 \\
\hline & & & & $\begin{array}{l}\text { WFR }=0.16 \text { or } \\
0.25\end{array}$ & 58 & 65 \\
\hline & & & \multicolumn{2}{|c|}{ Crawlspace } & 60 & 66 \\
\hline & & \multirow{2}{*}{$\mathrm{CFA}=2400$} & \multicolumn{2}{|c|}{ ENERGY STAR Appliances } & 62 & 67 \\
\hline & & & \multicolumn{2}{|c|}{ Standard Appliances } & 65 & 71 \\
\hline & \multirow{2}{*}{$\mathrm{CFA}=1200$} & \multicolumn{3}{|c|}{ ENERGY STAR Appliances } & 67 & 72 \\
\hline & & \multicolumn{3}{|c|}{ Standard Appliances } & 73 & 77 \\
\hline
\end{tabular}


Table 4.25. Corresponding HERS Index Ranges for Zone 4, Marine

\begin{tabular}{|c|c|c|c|c|c|}
\hline & & & & \multicolumn{2}{|c|}{$\begin{array}{l}\text { Corresponding } \\
\text { HERS Index } \\
\text { Range }\end{array}$} \\
\hline \multicolumn{4}{|c|}{ Characteristics Accounted For } & Min. & Max. \\
\hline \multirow{6}{*}{ None } & \multirow{4}{*}{$\begin{array}{l}\text { CFA }=2400 \text { or } \\
5000\end{array}$} & \multirow[b]{2}{*}{$\mathrm{CFA}=5000$} & $\mathrm{WFR}=0.12$ & 58 & 65 \\
\hline & & & $\begin{array}{l}\text { WFR }=0.16 \text { or } \\
0.25\end{array}$ & 60 & 68 \\
\hline & & \multirow{2}{*}{$\mathrm{CFA}=2400$} & $\begin{array}{l}\text { ENERGY STAR } \\
\text { Appliances }\end{array}$ & 65 & 71 \\
\hline & & & $\begin{array}{l}\text { Standard Appli- } \\
\text { ances }\end{array}$ & 70 & 75 \\
\hline & \multirow{2}{*}{$\mathrm{CFA}=1200$} & \multicolumn{2}{|c|}{ ENERGY STAR Appliances } & 73 & 77 \\
\hline & & \multicolumn{2}{|c|}{ Standard Appliances } & 79 & 82 \\
\hline
\end{tabular}

Table 4.26. Corresponding HERS Index Ranges for Zone 5, Moist

\begin{tabular}{|c|c|c|c|c|c|}
\hline & & & & $\begin{array}{r}\text { Corre } \\
\text { HEF }\end{array}$ & $\begin{array}{l}\text { onding } \\
\text { Index } \\
\text { ge }\end{array}$ \\
\hline & Char & stics Accounte & & Min. & Max. \\
\hline & & $\mathrm{CFA}=5000$ & & 55 & 64 \\
\hline & $\begin{array}{l}\text { CFA }=2400 \text { or } \\
5000\end{array}$ & $C F A=2400$ & $\begin{array}{l}\text { ENERGY STAR } \\
\text { Appliances }\end{array}$ & 63 & 69 \\
\hline None & & $C F A-2400$ & $\begin{array}{l}\text { Standard Appli- } \\
\text { ances }\end{array}$ & 66 & 71 \\
\hline & $C F A=1200$ & ENERGY S1 & liances & 72 & 76 \\
\hline & $C \Gamma A-1200$ & Standard ApI & & 77 & 81 \\
\hline
\end{tabular}

Table 4.27. Corresponding HERS Index Ranges for Zone 5, Dry

\begin{tabular}{|c|c|c|c|c|c|}
\hline & & & & $\begin{array}{r}\text { Corre } \\
\mathrm{HEF}\end{array}$ & $\begin{array}{l}\text { onding } \\
\text { Index } \\
\text { ge }\end{array}$ \\
\hline & & cteristics Acco & & Min. & Max. \\
\hline & & & Slab & 58 & 65 \\
\hline & & $C F A=5000$ & Crawlspace or Basement & 61 & 67 \\
\hline None & 5000 & $\mathrm{CFA}=2400$ & $\begin{array}{l}\text { ENERGY STAR Appli- } \\
\text { ances }\end{array}$ & 65 & 71 \\
\hline & & & Standard Appliances & 69 & 74 \\
\hline & $C F A=1200$ & ENERGY ST & liances & 73 & 77 \\
\hline & $C F A-1 \angle O 0$ & Standard App & & 79 & 82 \\
\hline
\end{tabular}


Table 4.28. Corresponding HERS Index Ranges for Zone 6, Moist

\begin{tabular}{|c|c|c|c|c|c|}
\hline & & & & \multicolumn{2}{|c|}{$\begin{array}{c}\text { Corresponding } \\
\text { HERS Index } \\
\text { Range }\end{array}$} \\
\hline \multicolumn{4}{|c|}{ Characteristics Accounted For } & Min. & Max. \\
\hline \multirow{5}{*}{ None } & \multirow{3}{*}{$\begin{array}{l}\mathrm{CFA}=2400 \text { or } \\
5000\end{array}$} & \multicolumn{2}{|c|}{ CFA $=5000$} & 55 & 63 \\
\hline & & \multirow[t]{2}{*}{$\mathrm{CFA}=2400$} & $\begin{array}{l}\text { ENERGY STAR } \\
\text { Appliances }\end{array}$ & 62 & 67 \\
\hline & & & Standard Appliances & 65 & 70 \\
\hline & \multirow{2}{*}{$\mathrm{CFA}=1200$} & \multicolumn{2}{|c|}{ ENERGY STAR Appliances } & 71 & 75 \\
\hline & & \multicolumn{2}{|c|}{ Standard Appliances } & 75 & 79 \\
\hline
\end{tabular}

Table 4.29. Corresponding HERS Index Ranges for Zone 6, Dry

\begin{tabular}{|c|c|c|c|c|c|}
\hline & & & & \multicolumn{2}{|c|}{$\begin{array}{l}\text { Corresponding } \\
\text { HERS Index } \\
\text { Range }\end{array}$} \\
\hline \multicolumn{4}{|c|}{ Characteristics Accounted For } & Min. & Max. \\
\hline \multirow{5}{*}{ None } & \multirow{3}{*}{$\begin{array}{l}\mathrm{CFA}=2400 \text { or } \\
5000\end{array}$} & \multicolumn{2}{|c|}{$\mathrm{CFA}=5000$} & 58 & 65 \\
\hline & & \multirow[t]{2}{*}{$\mathrm{CFA}=2400$} & $\begin{array}{l}\text { ENERGY STAR } \\
\text { Appliances }\end{array}$ & 64 & 69 \\
\hline & & & Standard Appliances & 67 & 72 \\
\hline & \multirow{2}{*}{$\mathrm{CFA}=1200$} & \multicolumn{2}{|c|}{ ENERGY STAR Appliances } & 72 & 76 \\
\hline & & \multicolumn{2}{|c|}{ Standard Appliances } & 77 & 81 \\
\hline
\end{tabular}

Table 4.30. Corresponding HERS Index Ranges for Zone 7

\begin{tabular}{|c|c|c|c|c|}
\hline & & & \multicolumn{2}{|c|}{$\begin{array}{l}\text { Corresponding } \\
\text { HERS Index } \\
\text { Range }\end{array}$} \\
\hline \multicolumn{3}{|c|}{ Characteristics Accounted For } & Min. & Max. \\
\hline \multirow{4}{*}{ None } & \multirow{2}{*}{$\begin{array}{l}\text { CFA }=2400 \text { or } \\
5000\end{array}$} & $\mathrm{CFA}=5000$ & 53 & 60 \\
\hline & & $\mathrm{CFA}=2400$ & 61 & 68 \\
\hline & \multirow{2}{*}{$\mathrm{CFA}=1200$} & ENERGY STAR Appliances & 71 & 73 \\
\hline & & Standard Appliances & 74 & 77 \\
\hline
\end{tabular}


Table 4.31. Corresponding HERS Index Ranges for Zone 8

\begin{tabular}{|c|c|c|c|c|}
\hline & & & \multicolumn{2}{|c|}{$\begin{array}{l}\text { Corresponding } \\
\text { HERS Index } \\
\text { Range }\end{array}$} \\
\hline \multicolumn{3}{|c|}{ Characteristics Accounted For } & Min. & Max. \\
\hline \multirow{4}{*}{ None } & \multirow{2}{*}{$\begin{array}{l}\text { CFA }=2400 \text { or } \\
5000\end{array}$} & $\mathrm{CFA}=5000$ & 55 & 60 \\
\hline & & $\mathrm{CFA}=2400$ & 63 & 67 \\
\hline & \multirow{2}{*}{$\mathrm{CFA}=1200$} & ENERGY STAR Appliances & 72 & 75 \\
\hline & & Standard Appliances & 75 & 78 \\
\hline
\end{tabular}





\subsection{Conclusions and Recommendations}

The relationship between the HERS Index and compliance through IECC's Performance Path is complex and difficult to generalize. This analysis has shown how the Corresponding HERS Index varies as a function of multiple home characteristics and provided climate zone-specific details on the ranges of HERS Index values that are likely to imply comparable compliance with the IECC Performance Path when the most significant home characteristics are accounted for. Because these results are nuanced and different in each climate zone, it is recommended that code developers and policy makers carefully consider the details for the zone(s) of interest and use these results to inform the decisions related to a HERS Index-based IECC compliance path.

The complexity and variability of results notwithstanding, the following observations are generally important:

- As expected, HVAC efficiency is a crucial variable in determining the Corresponding HERS Index values. Depending on the climate zone and specific equipment efficiencies, the use of condensing gas furnaces (AFUE of 90 or more) and high-efficiency air conditioning lowers the Corresponding HERS Index threshold by 3 to 10 HERS points.

- Among the house/envelope characteristics evaluated in this study, house size (CFA) has the greatest impact on Corresponding HERS Index values. A HERS Index-based IECC compliance path must account for house size to be reasonably equivalent to the existing IECC Performance Path. The relationship between Corresponding HERS Index and CFA is nonlinear, being relatively more important for small-to-average homes. This analysis found that the impact on Corresponding HERS Index of increasing CFA from 1200 to $2400 \mathrm{ft}^{2}$ is approximately equal to that of increasing CFA from 2400 to $5000 \mathrm{ft}^{2}$.

- The credit given by the HERS standards to high-efficiency appliances is the third most important home characteristic, an expected outcome given that appliance energy use is outside the scope of the IECC and hence receives no compliance credit in the IECC Performance Path.

- Smaller, but significant, impacts were seen for foundation type and window-floor ratio (WFR). Depending on the climate zone, these variables may or may not necessarily be accounted for in a HERS Index-based compliance path. The remaining variables-number of stories and glazing orientation-have an impact in some cases, but not usually at a significant level relative to the other characteristics.

- The lowest Corresponding HERS Index values identified in this analysis, adjusted to account for high-efficiency HVAC, are generally similar to, albeit slightly lower (better) than, the thresholds in the 2015 IECC’s ERI compliance path. 



\subsection{References}

ASHRAE - American Society of Heating, Refrigerating and Air-Conditioning Engineers. 2001. 2001 ASHRAE Handbook: Fundamentals. Atlanta, Georgia.

Briggs RS, RG Lucas, and ZT Taylor. 2002. "Climate Classification for Building Energy Codes and Standards: Part 2- Zone Definitions, Maps, and Comparisons.” ASHRAE Transactions 109 Part 1.

Fairey P, J Tait, D Tracey, M Holtz, and R Judkoff. 2000. The HERS Rating Method and the Derivation of the Normalized Modified Loads Method. FSEC-RR-54-00, Florida Solar Energy Center, Cocoa, Florida.

Fairey P. 2014. Comparative Performance Analysis: HERS Index Score Dependencies Related to Home Geometries and Operating Assumptions. FSEC-RR-484-14, Florida Solar Energy Center, Cocoa, Florida. International Code Council (ICC). 2011. International Energy Conservation Code 2012. Country Club Hills, Illinois.

Lucas R. 2009. Determination for the 2006 International Energy Conservation Code, Residential Buildings - Technical Support Document. PNNL-18806, Pacific Northwest National Laboratory, Richland, Washington.

Mendon V, R Lucas and S Goel. 2013. Cost-Effectiveness Analysis of the 2009 and 2012 IECC Residential Provisions - Technical Support Document. PNNL-22068, Pacific Northwest National Laboratory, Richland, Washing-

ton. http://www.energycodes.gov/sites/default/files/documents/State_CostEffectiveness TSD Final.pdf.

RESNET - Residential Energy Services Network. 2013. Mortgage Industry National Home Energy Rating Systems Standards. Accessed July 1, 2013, at http://www.resnet.us/standards/RESNET_Mortgage_Industry_National_HERS_Standards.pdf.

Taylor T, N Fernandez, and R Lucas. 2012. Methodology for Evaluating Cost-Effectiveness of Residential Energy Code Changes. PNNL-21888, Pacific Northwest National Laboratory, Richland, Washington. http://www.energycodes.gov/sites/default/files/documents/residential_methodology.pdf

Taylor T, and S Goel. 2013. A Preliminary Feasibility Assessment of the RESNET HERS Index as an Alternative Compliance Path for the IECC. PNNL-23021, Pacific Northwest National Laboratory, Richland, Washington.

Therneau T and EJ Atkinson. 2013. An Introduction to Recursive Partitioning Using the RPART Routines. Mayo Clinic, Rochester Minnesota. Accessed July 1, 2013 at http://cran.rproject.org/web/packages/rpart/vignettes/longintro.pdf. 



\section{Appendix}

\section{Corresponding HERS Index Graphics}





\section{Appendix}

\section{Corresponding HERS Index Graphics}

\section{A.1 Definition and Layout of Graphics}

The figures in this Appendix are a visual representation of the Corresponding HERS Index values calculated for this analysis. The procedure used to calculate the Corresponding HERS Index values is described in detail in Section 3.4, with further description of the visual elements of the figures in Section 2.5. The calculated Corresponding HERS Index values are the data used to develop the model decision trees shown in Section 4.1.3. Figures A.1 through A.15 show detail on the Corresponding HERS Index values not shown in the summary results of this report. The figures cover all aspects of the energy simulation analyses:

- There are 15 figures, one for each climate zone analyzed.

- Each figure (climate zone) has eight parts, one each for the eight home characteristics used in the analysis.

1. heat pump efficiency

2. gas/AC efficiency

3. window-floor ratio (WFR)

4. conditioned floor area (CFA)

5. foundation type

6. appliance efficiency

7. glazing orientation

8. number of stories

- Each of the eight parts (characteristics) contains a number of separate panels, each representing one level of the given characteristic.

- Each panel (characteristic level) shows the calculated Corresponding HERS Index value for the associated level of the given characteristic; the value is shown both by the location of the dashed crosshairs and by a printed number. ${ }^{1}$

- Each Corresponding HERS Index value derives from three data points representing a middle prescriptive-minimum configuration, a higher-efficiency configuration, and a lower-efficiency configuration.

\footnotetext{
${ }^{1}$ Note that the HERS Index is defined to be an integer value. However, this analysis retains one decimal of precision to aid in visualizing the impacts of interest.
} 
A linear curve fit to those points defines the Corresponding HERS Index value where it crosses the line of IECC Compliance Ratio $=1.0$.

\section{A.2 Interpretation of Graphics}

As an example to aid in interpreting these graphics, consider the Gas Furnace and AC Efficiency part of Figure A.1. That part shows how the Corresponding HERS Index varies with changing AFUE and SEER values, assuming all other characteristics are held at their prescriptive-minimum levels (the medium "M" values in Table 3.3). The graphic can be interpreted thusly:

- The bottom panel shows that for the Base HVAC level (AFUE and SEER at federal minimum values), a HERS Index of 76.2 is required to ensure the prototype home complies via the IECC Performance Path.

- The other panels, from bottom to top, show progressively increasing HVAC efficiencies (see Table 2.2 for specific AFUE and SEER values corresponding to the "High-eff” packages).

- Note that as HVAC efficiency of the proposed/rated home increases (moving to higher panels in the graphic), the required HERS Index gets lower. At the highest efficiency level ("High-eff Gas3”), a HERS Index of 65.8 is required to ensure the prototype home complies with the IECC. This is more than 10 HERS points lower (better) than for the Base HVAC case.

- Because the HERS methodology gives credit for higher HVAC efficiency while the IECC does not, a lower (better) HERS Index is needed to ensure the remainder of the building (envelope insulation, air leakage, etc.) will comply with the IECC.

All other characteristics can be interpreted similarly. Note, however, that higher panels do not always represent higher efficiencies as they do for Gas Furnace and AC Efficiency. For some characteristics (e.g., Foundation, Number of Stories), there is no obvious progression from lower to higher efficiency, while for others (e.g., Appliances), the higher-efficiency level is on the lower panel. 


\section{Heat Pump Efficiency}

$P$

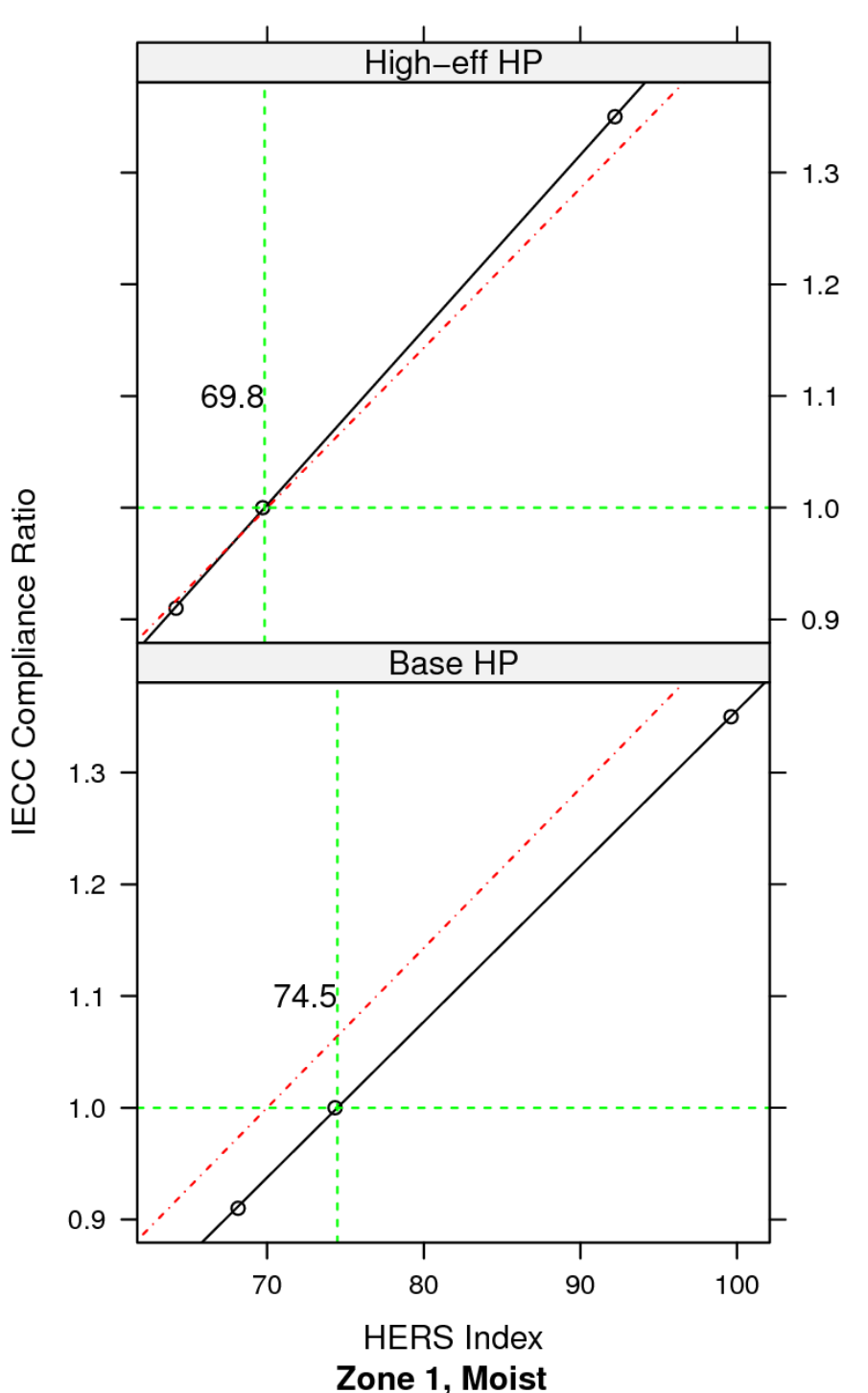

Gas Furnace \& AC Efficiency

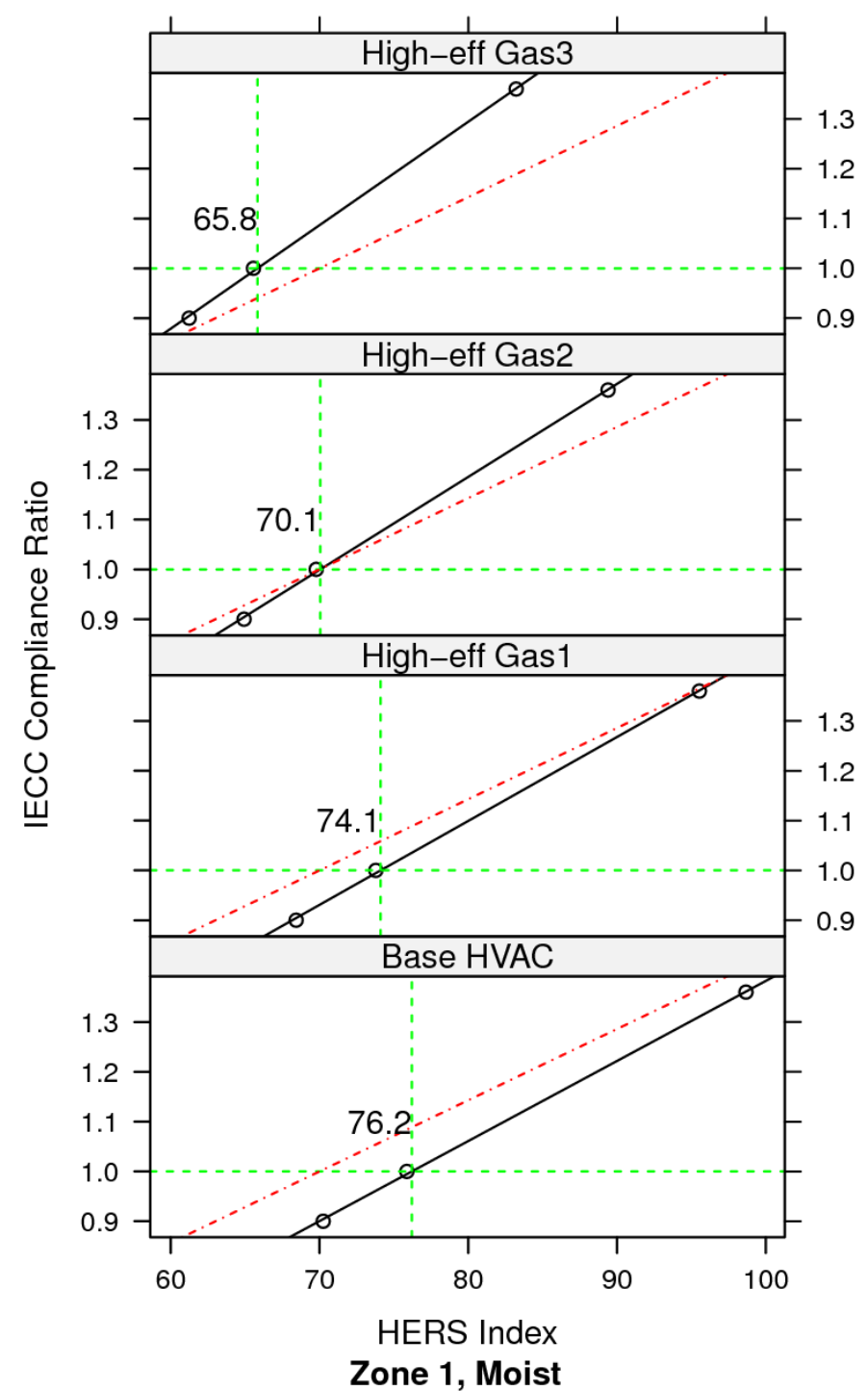

Figure A.1. Corresponding HERS Indexes for Climate Zone 1, Moist Regime 
Window-Floor Ratio

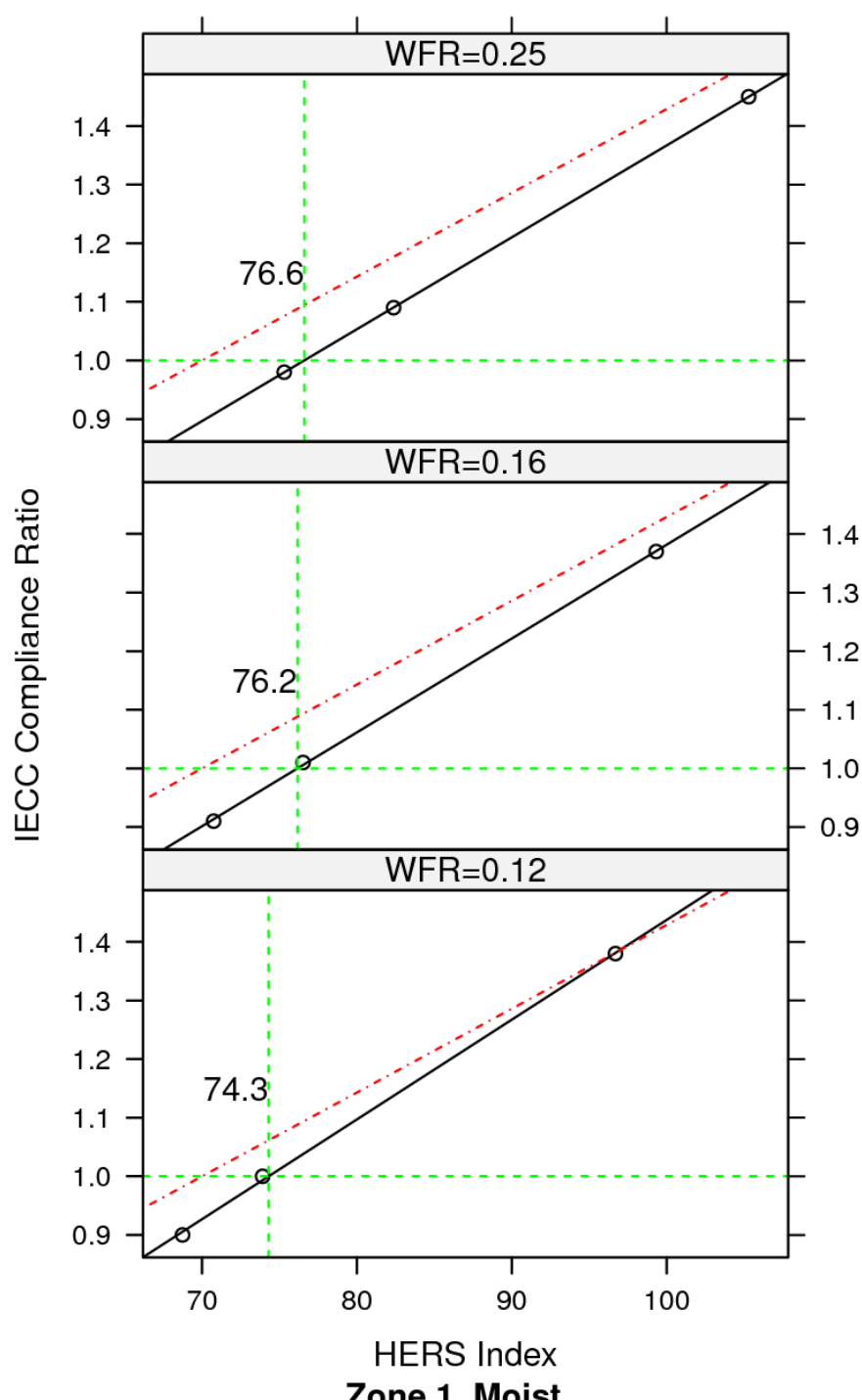

\section{Conditioned Floor Area}

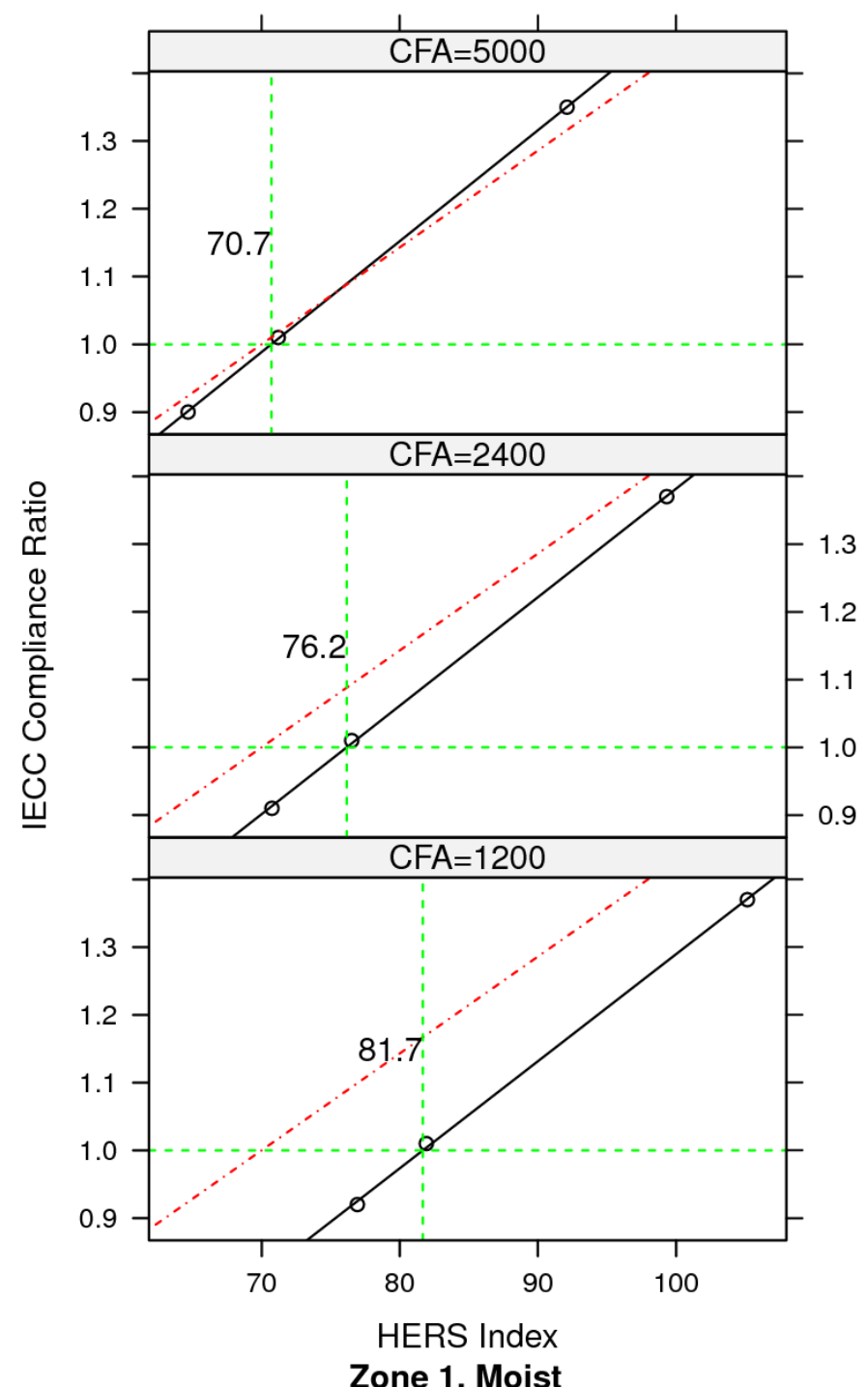

Figure A.1. Corresponding HERS Indexes for Climate Zone 1, Moist Regime (continued) 
Foundation

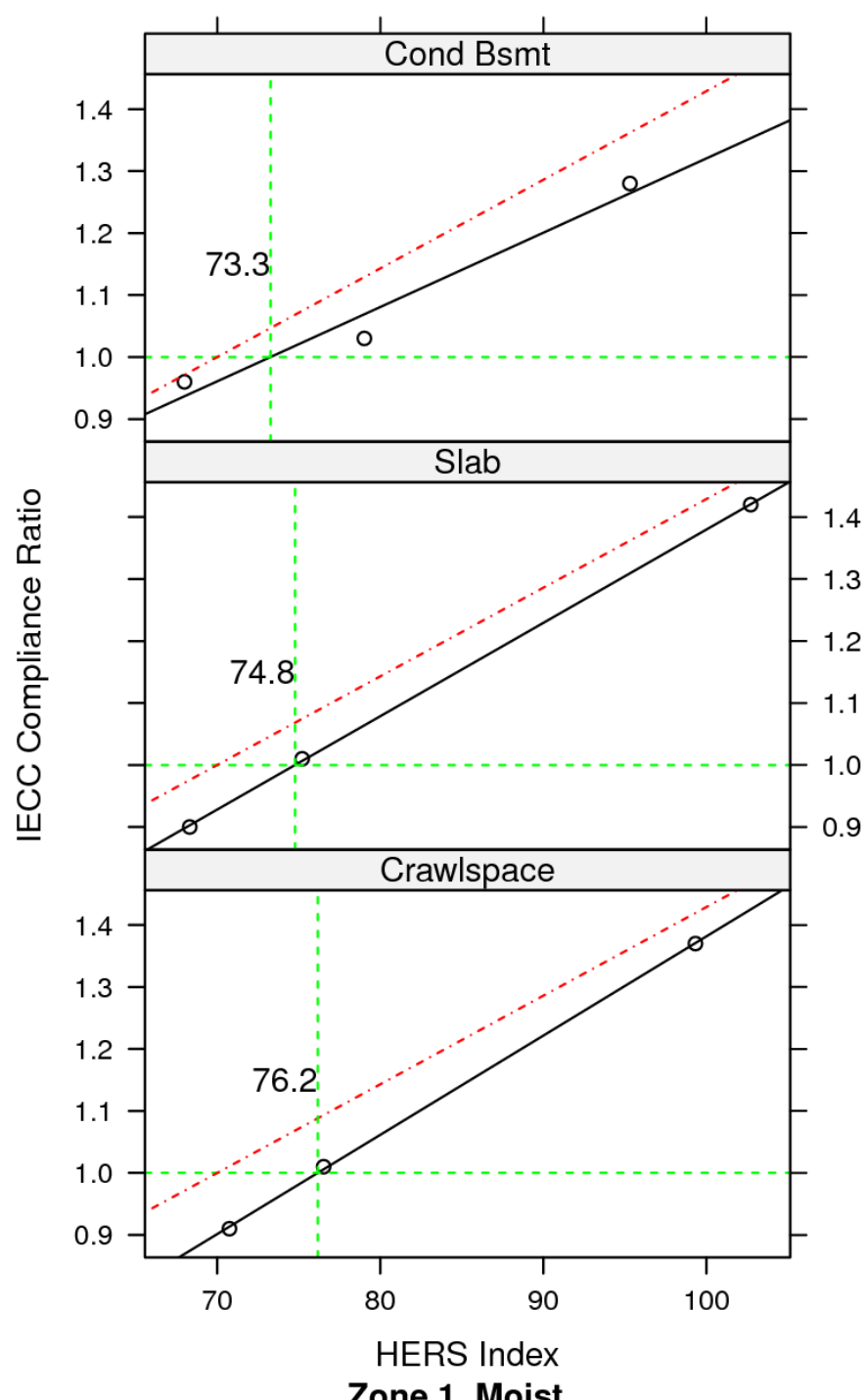

Appliances

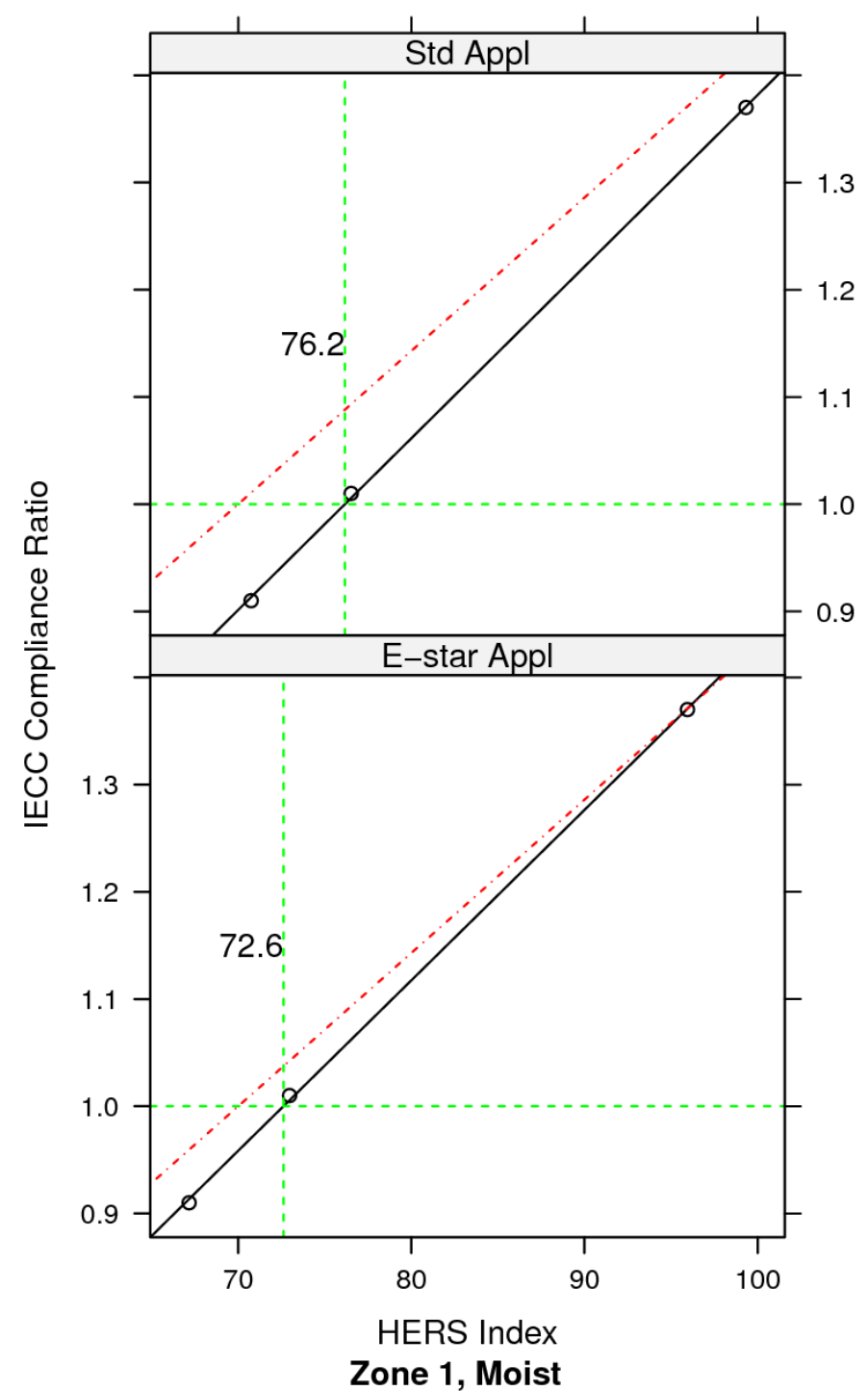

Figure A.1. Corresponding HERS Indexes for Climate Zone 1, Moist Regime (contd) 


\section{Glazing Orientation}

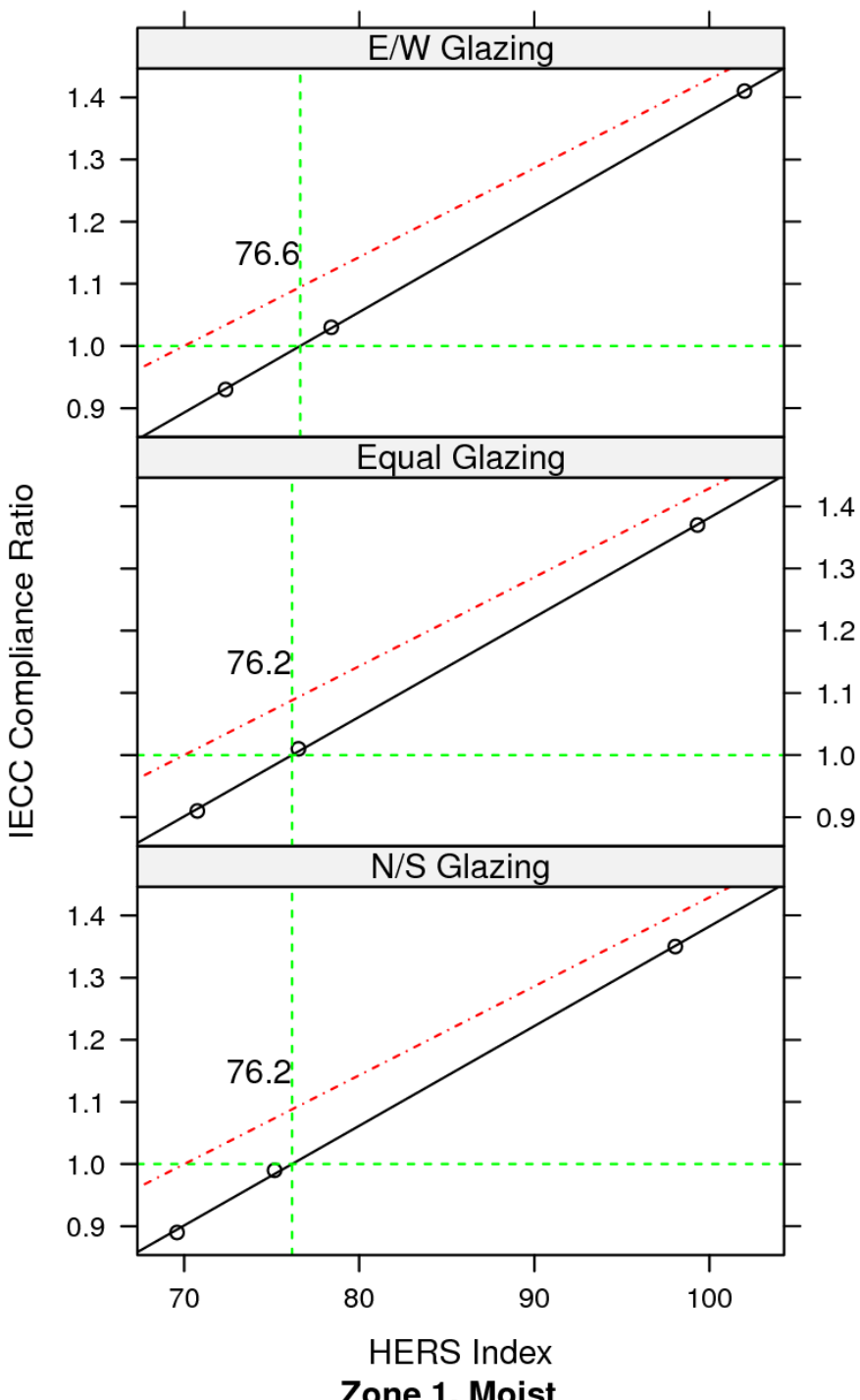

Number of Stories

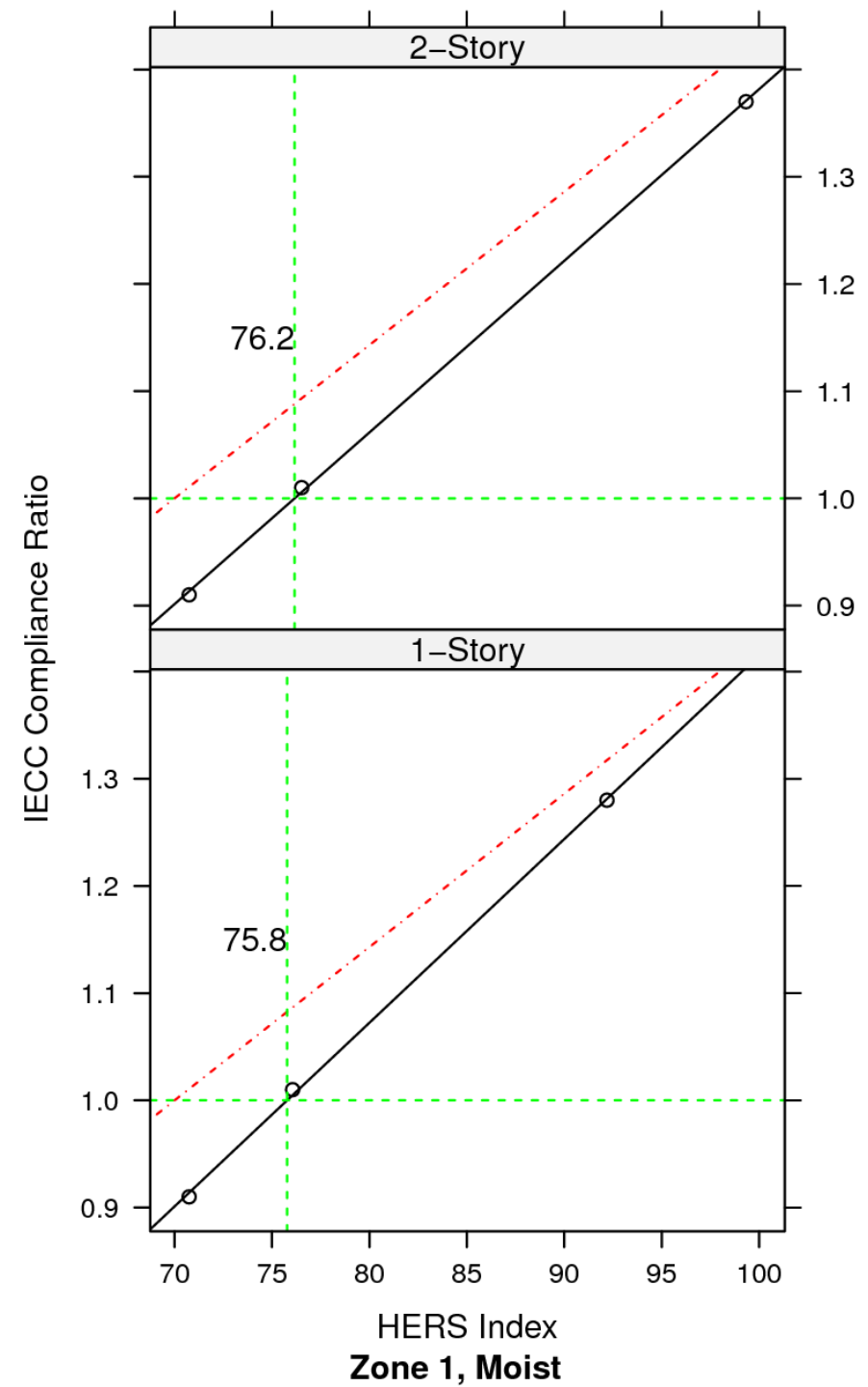

Figure A.1. Corresponding HERS Indexes for Climate Zone 1, Moist Regime (contd) 


\section{Heat Pump Efficiency}

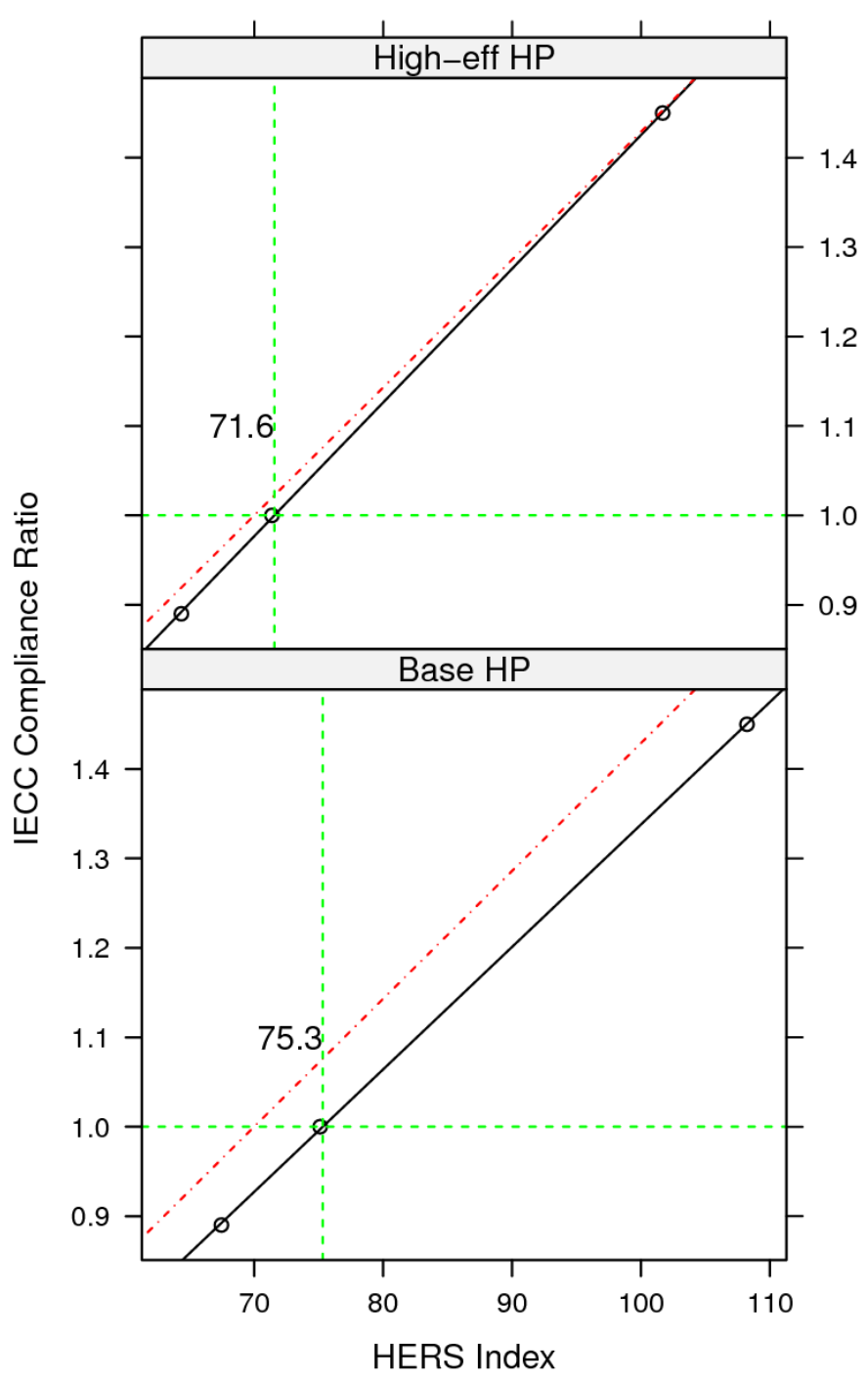

Zone 2, Moist
Gas Furnace \& AC Efficiency

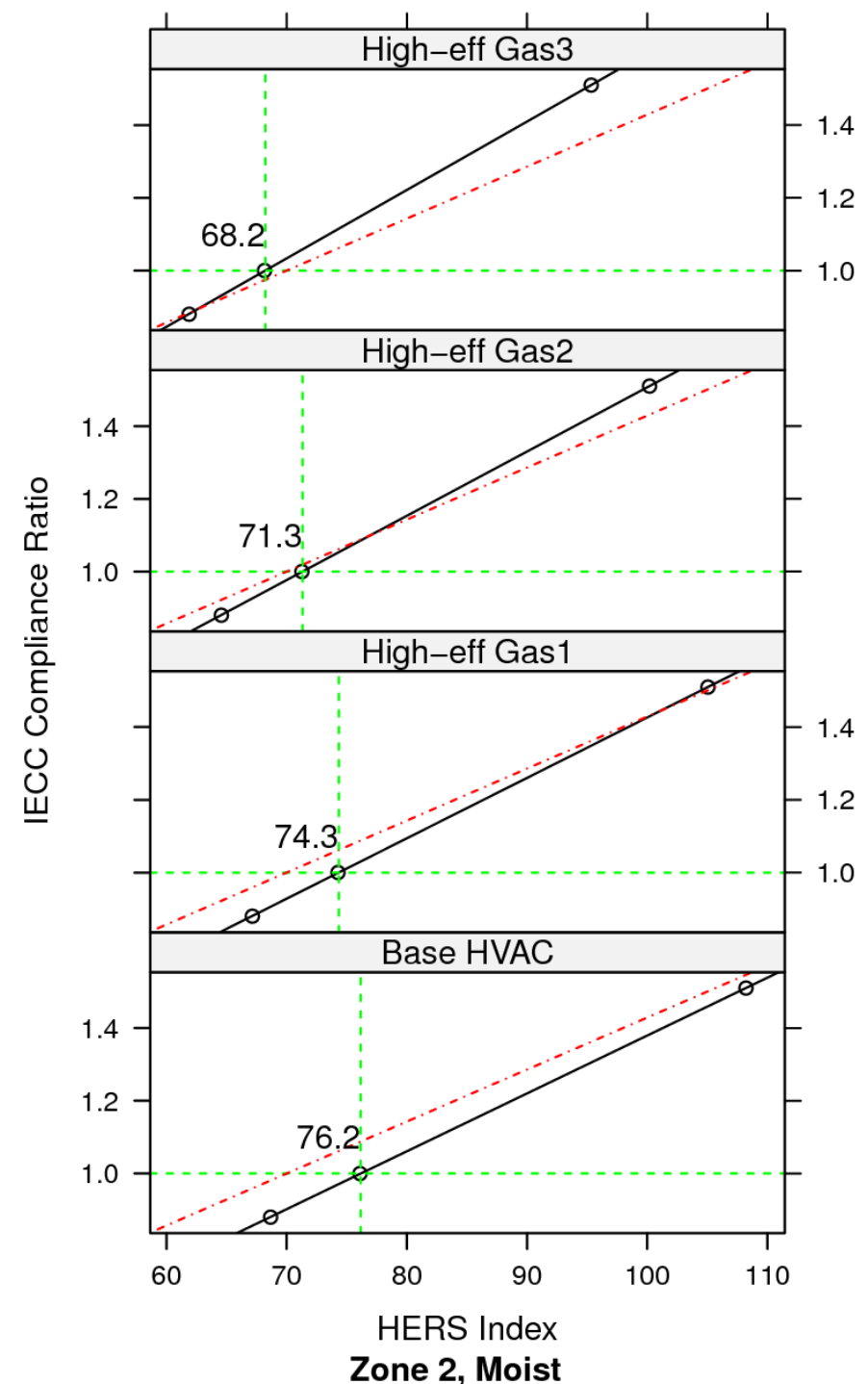

Figure A.2. Corresponding HERS Indexes for Climate Zone 2, Moist Regime 
Window-Floor Ratio

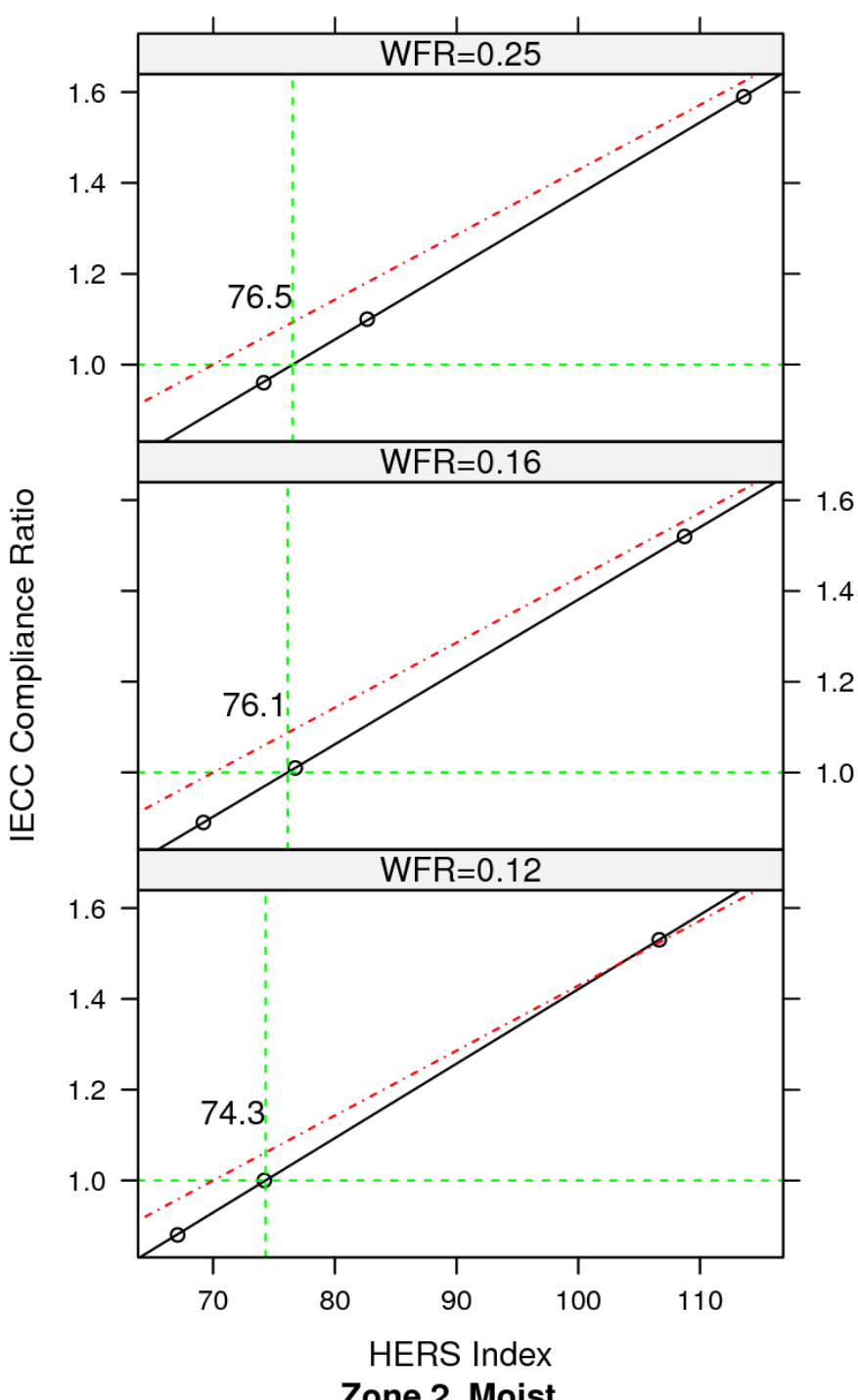

\section{Conditioned Floor Area}

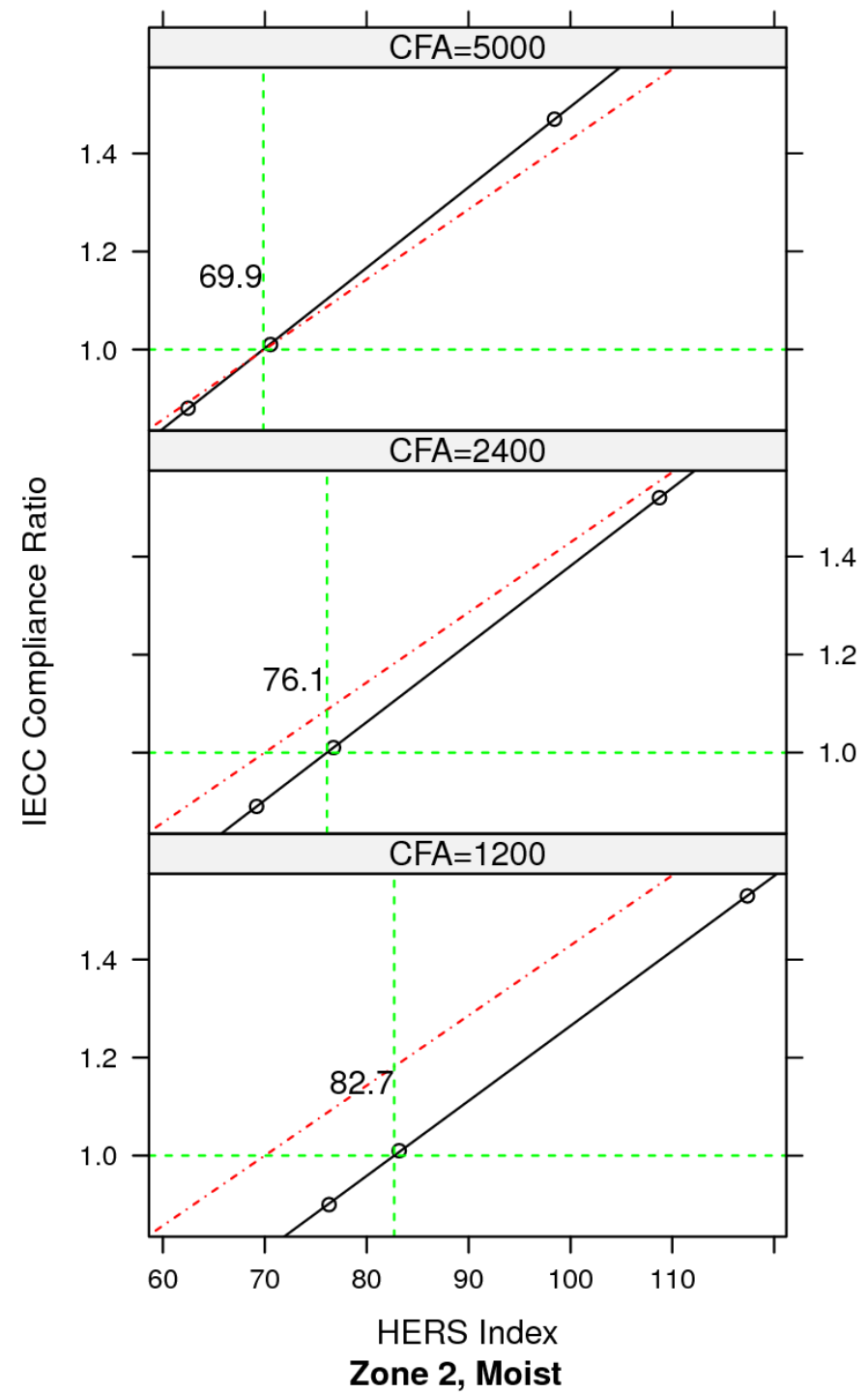

Figure A.2. Corresponding HERS Indexes for Climate Zone 2, Moist Regime (contd) 
Foundation

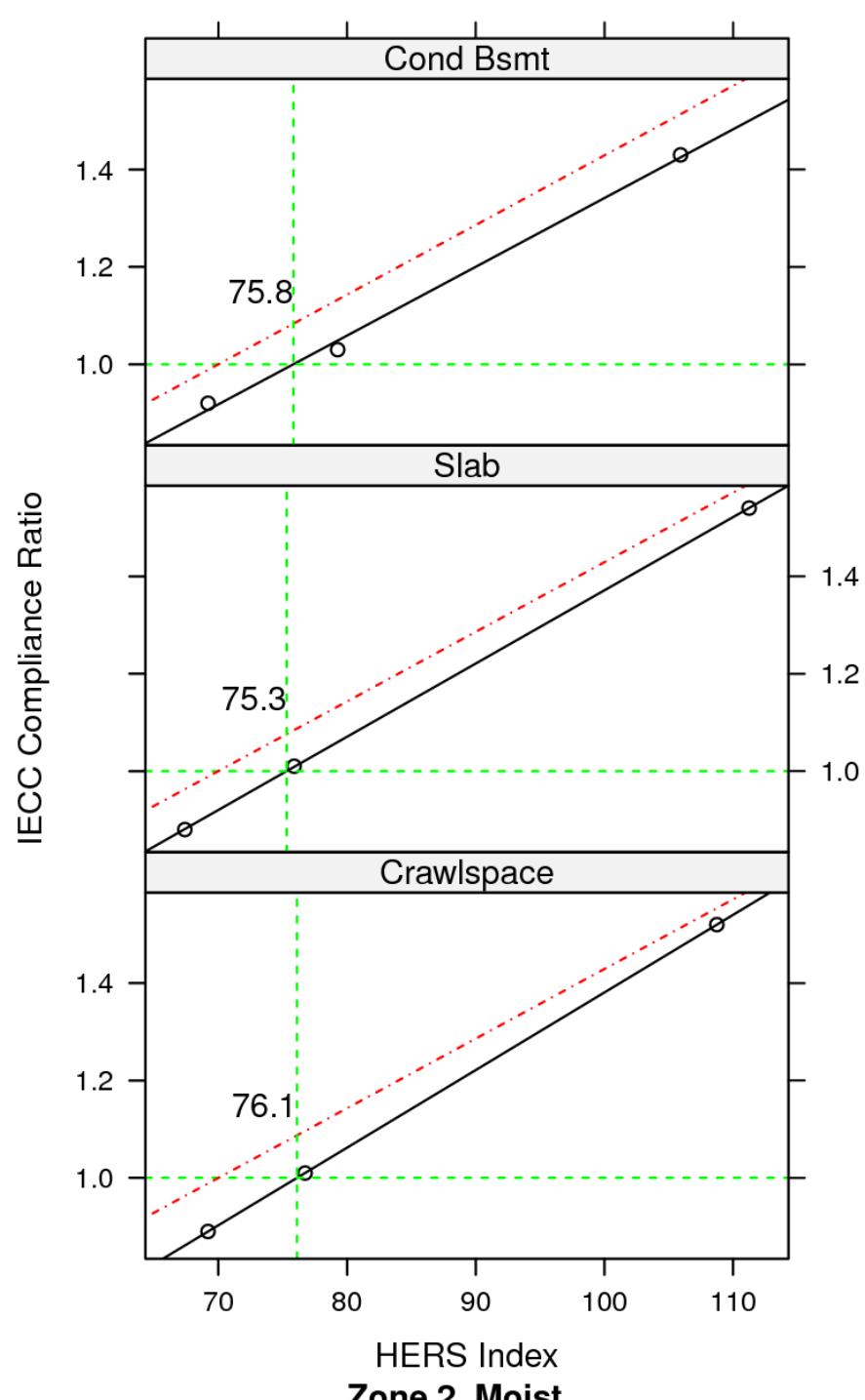

Appliances

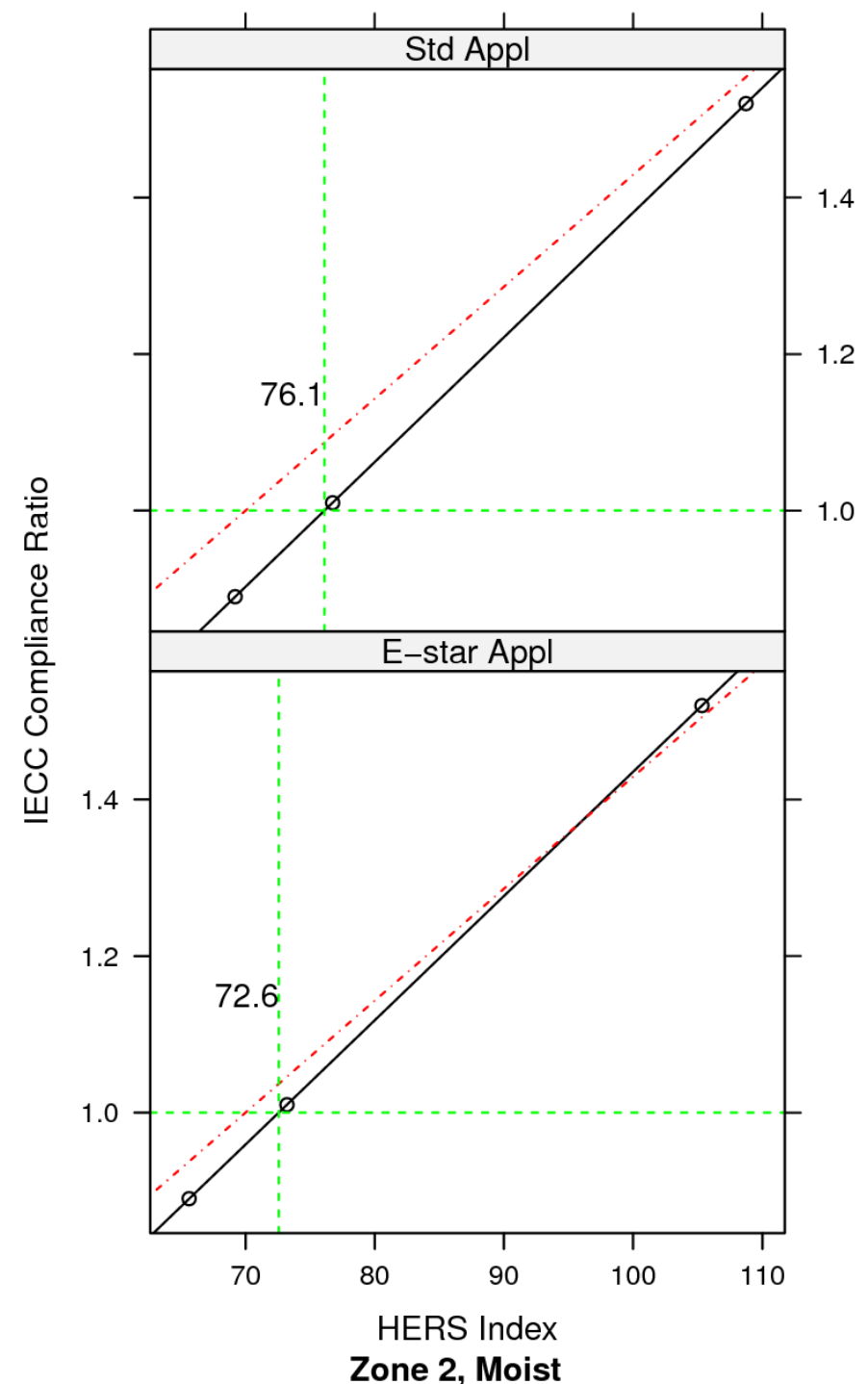

Figure A.2. Corresponding HERS Indexes for Climate Zone 2, Moist Regime (contd) 


\section{Glazing Orientation}
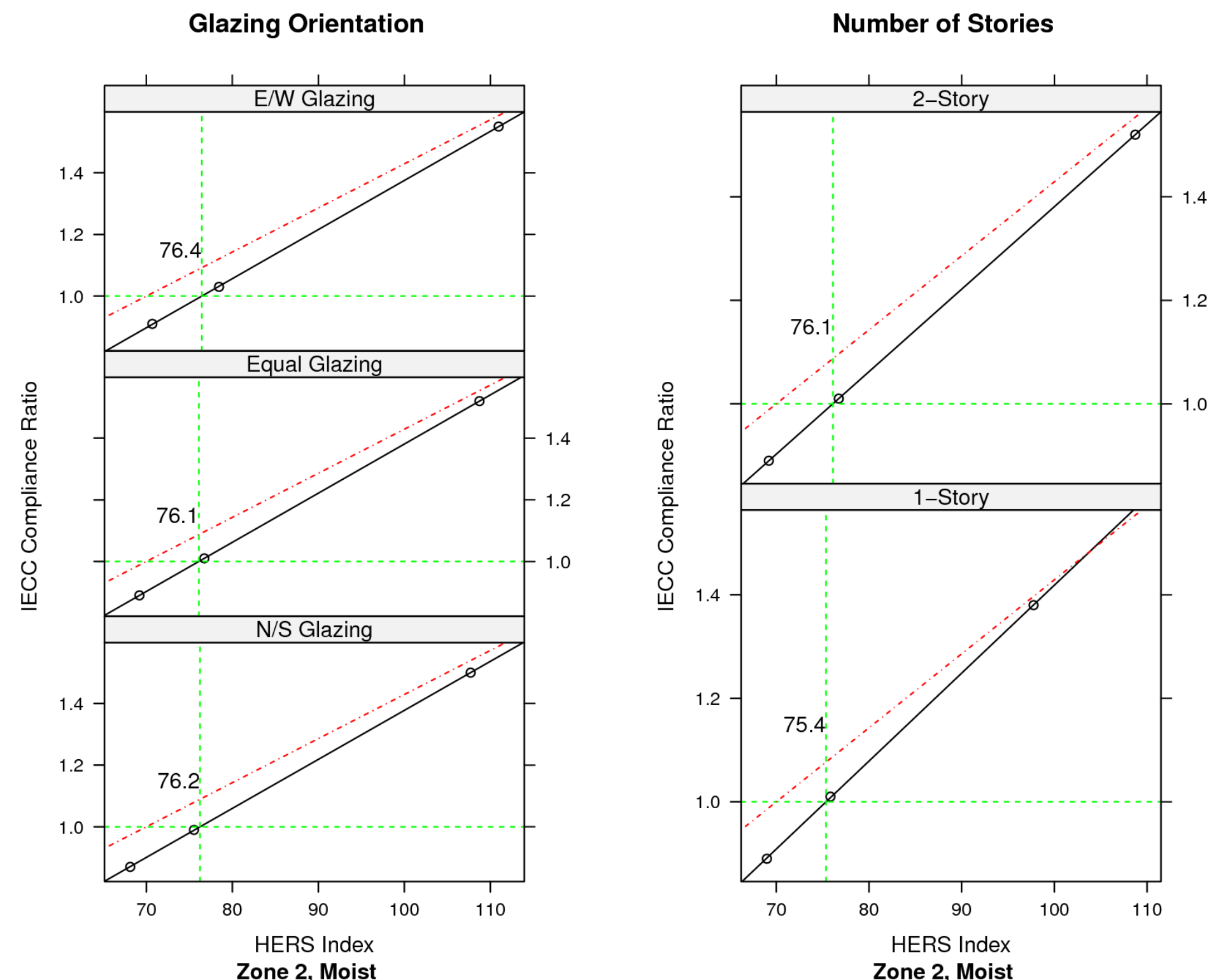

Figure A.2. Corresponding HERS Indexes for Climate Zone 2, Moist Regime (contd) 
Heat Pump Efficiency

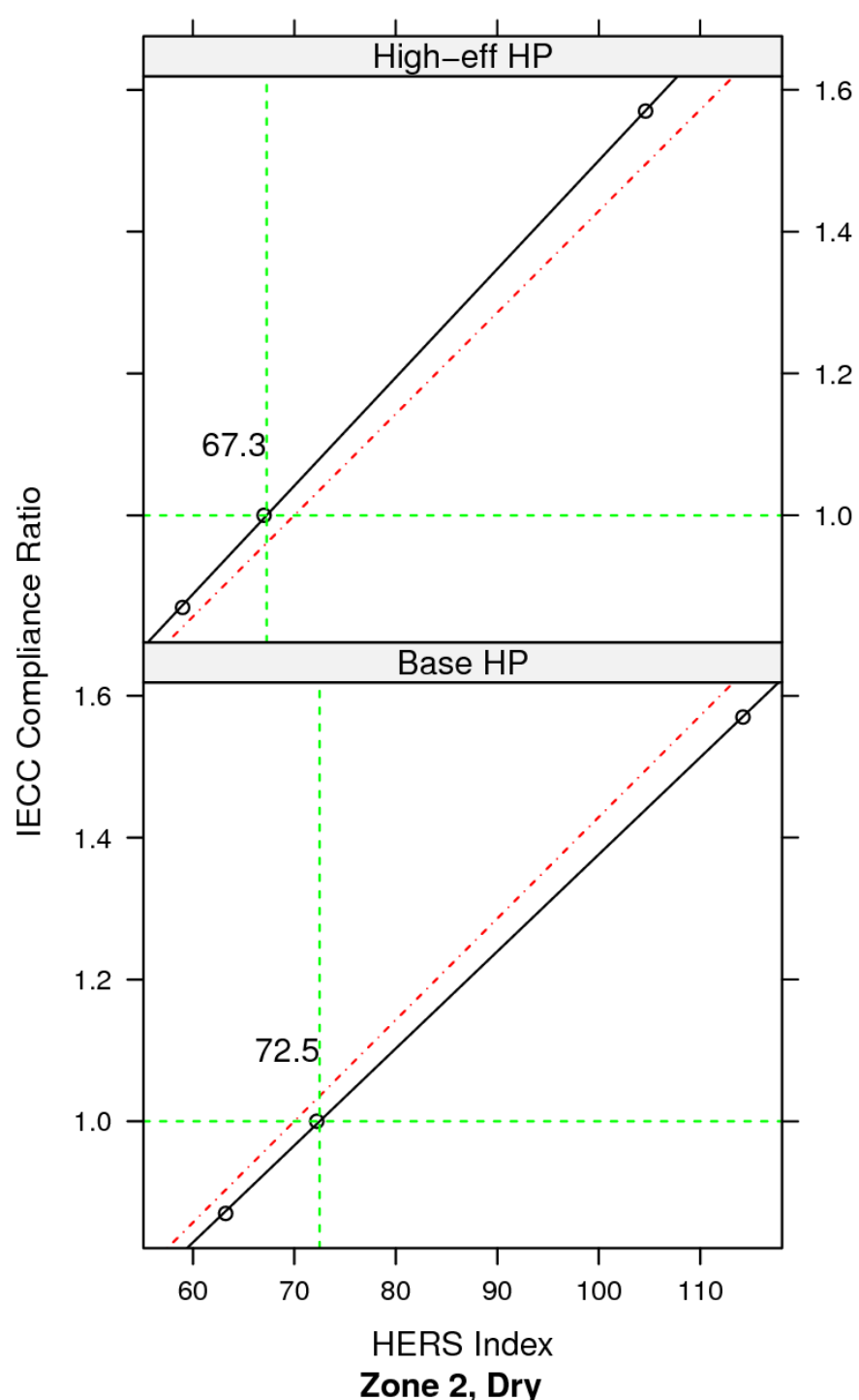

Gas Furnace \& AC Efficiency

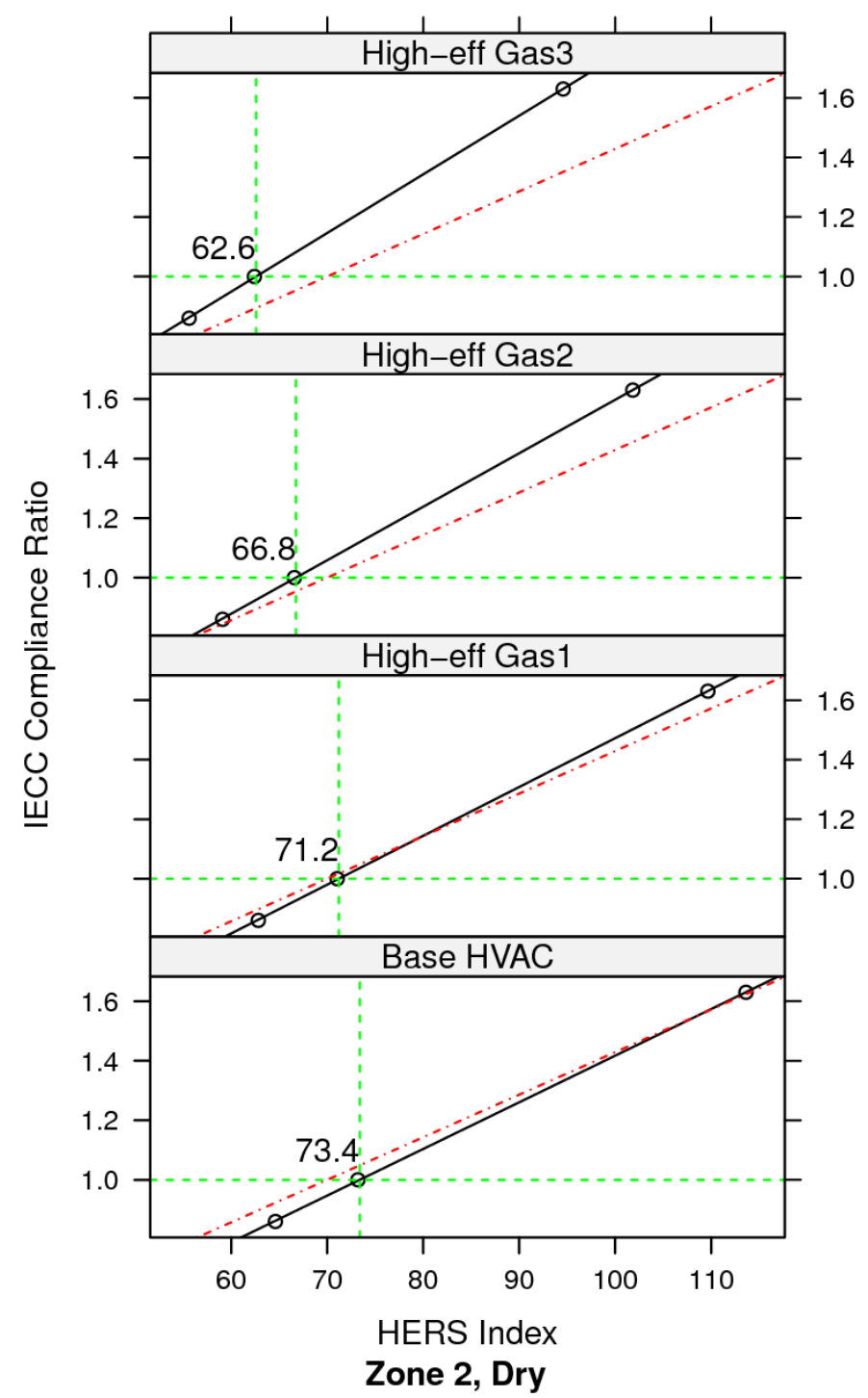

Figure A.3. Corresponding HERS Indexes for Climate Zone 2, Dry Regime 
Window-Floor Ratio

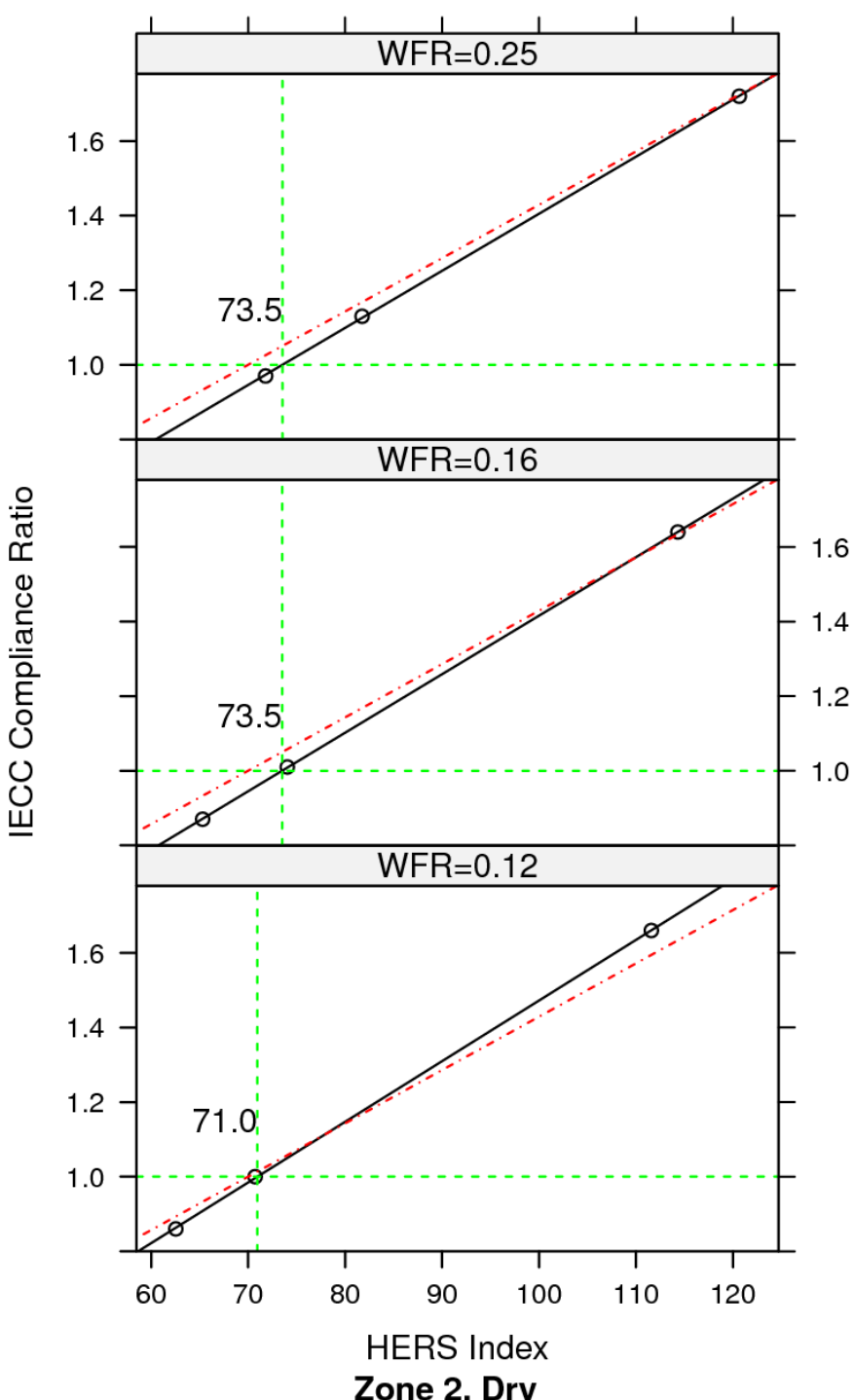

Conditioned Floor Area

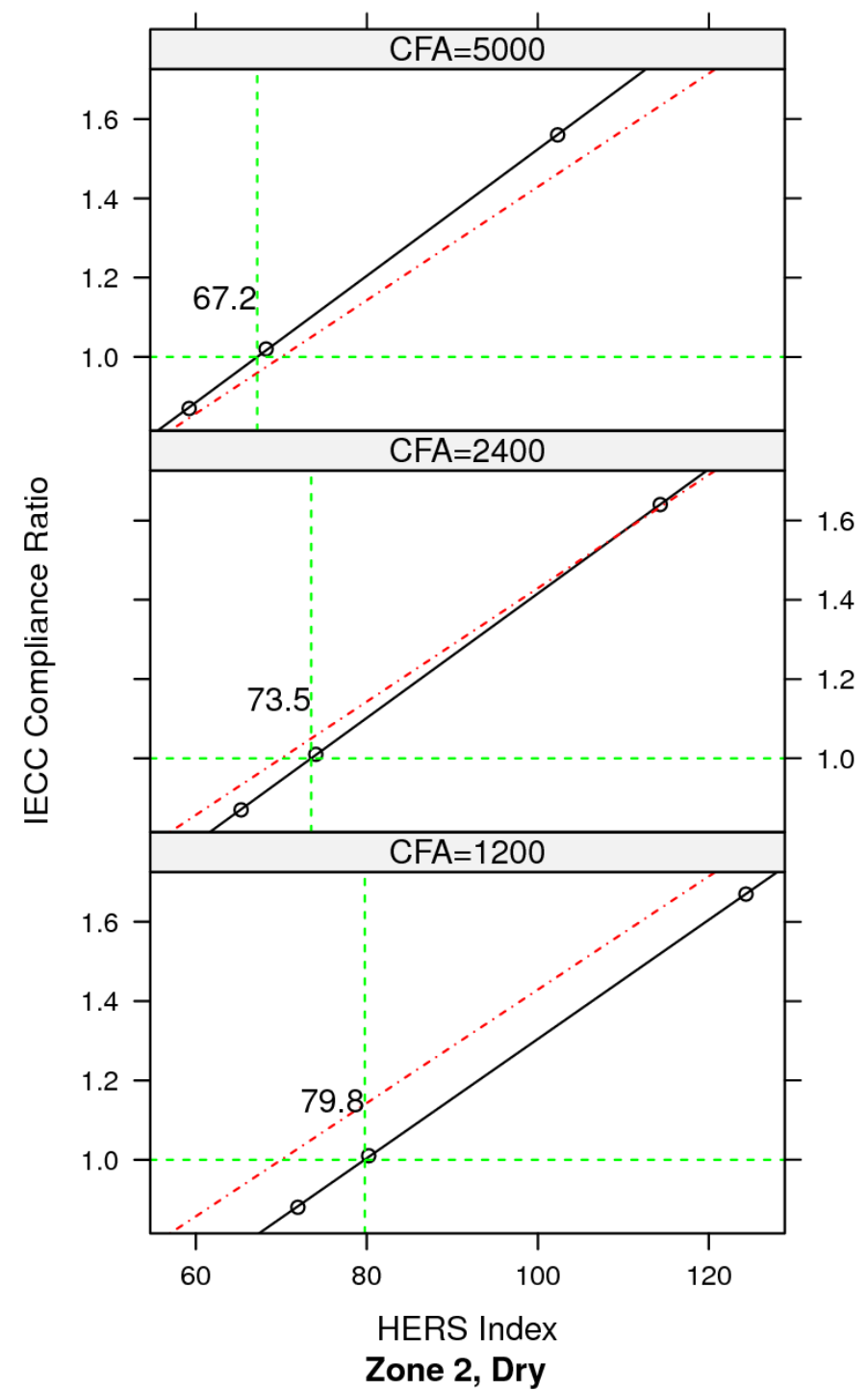

Figure A.3. Corresponding HERS Indexes for Climate Zone 2, Dry Regime (contd) 
Foundation

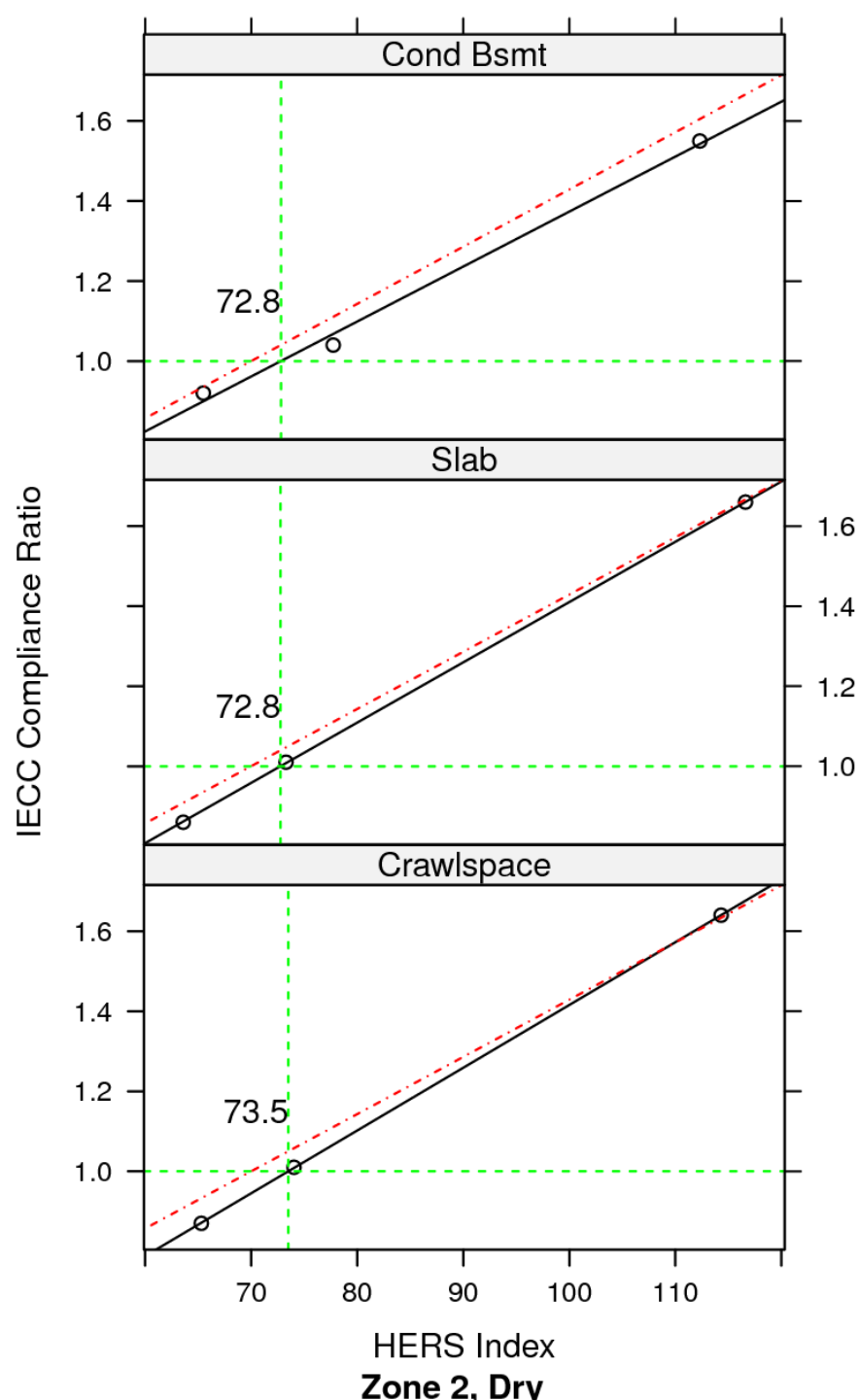

Appliances

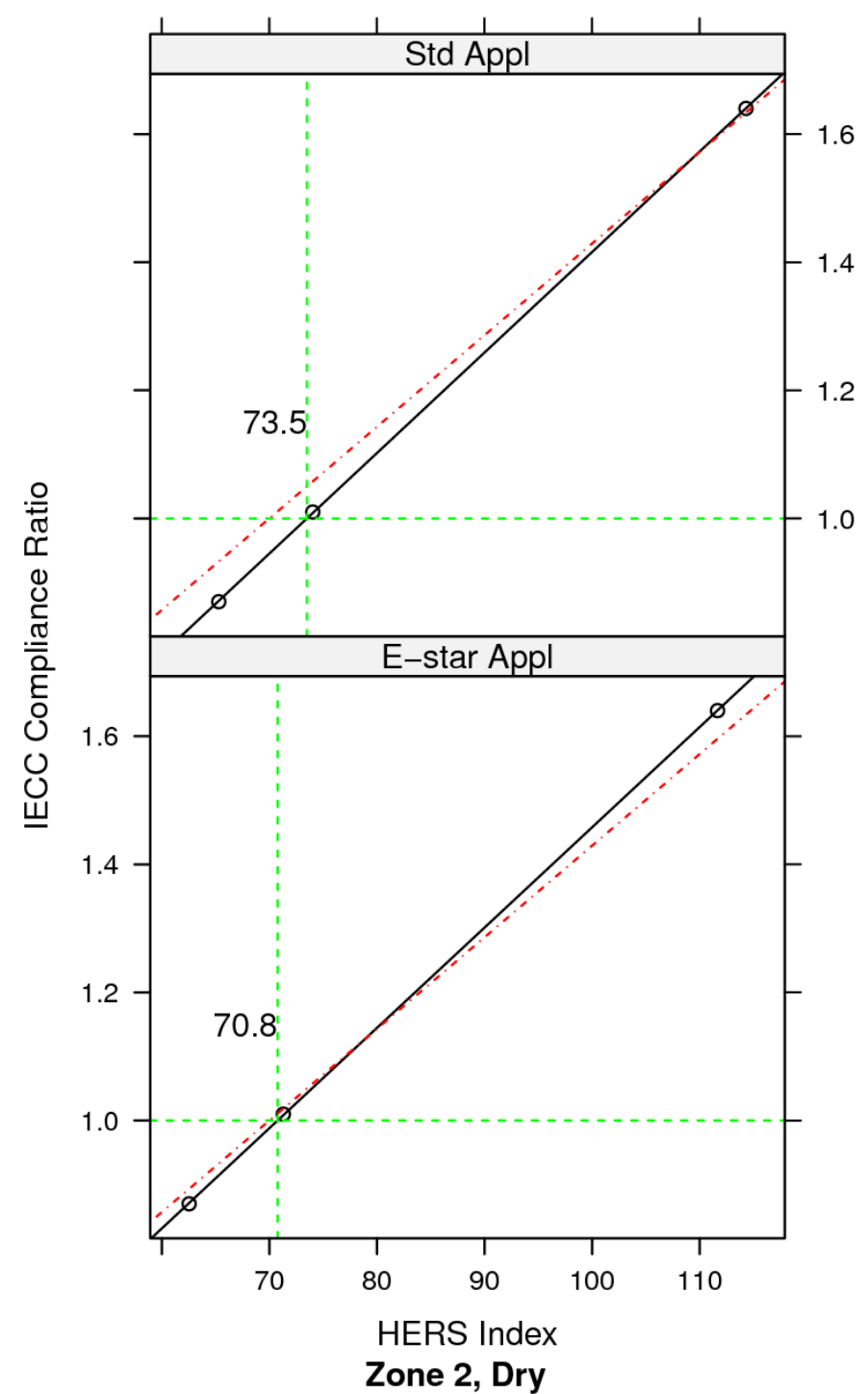

Figure A.3. Corresponding HERS Indexes for Climate Zone 2, Dry Regime (contd) 


\section{Glazing Orientation}

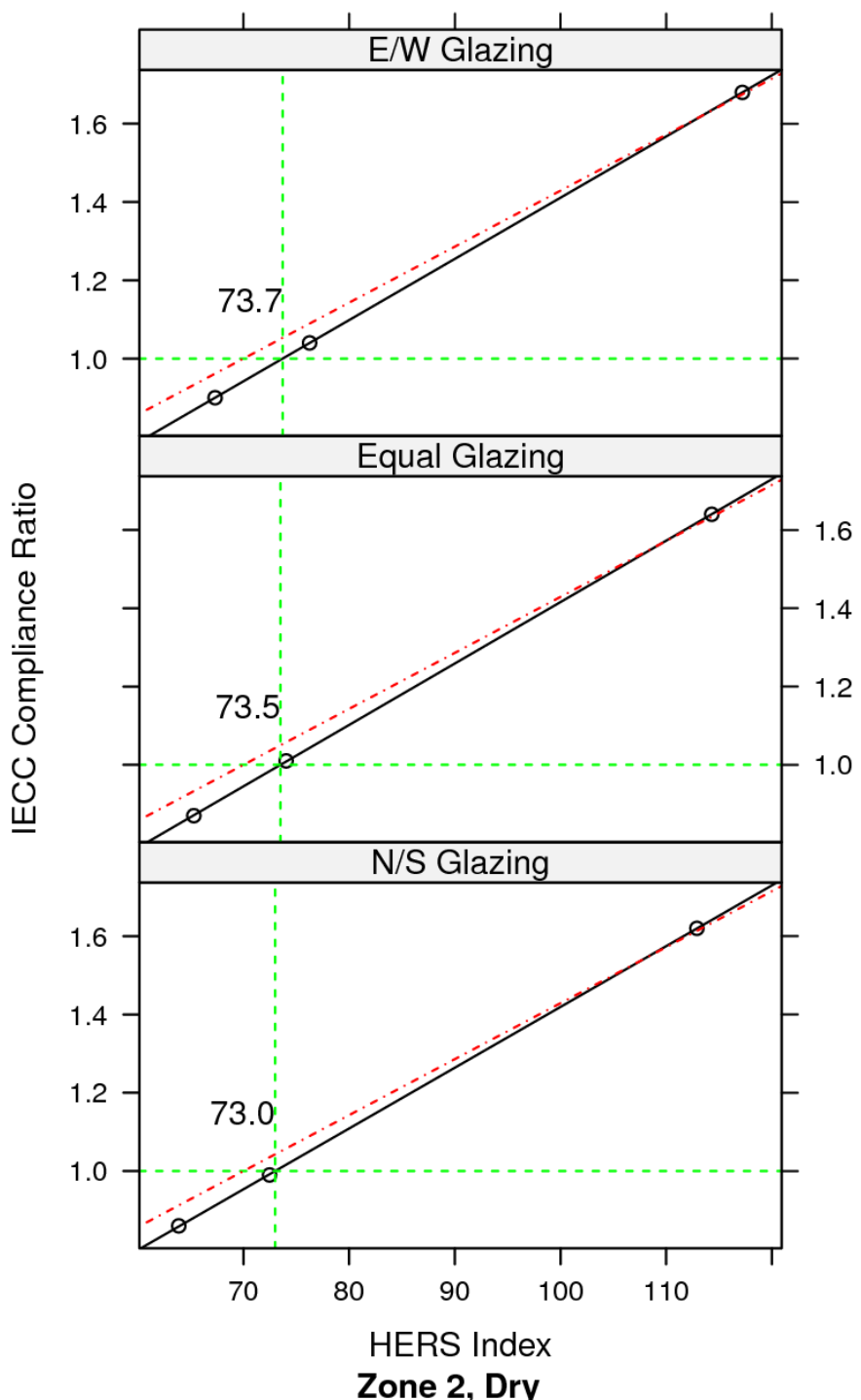

Number of Stories

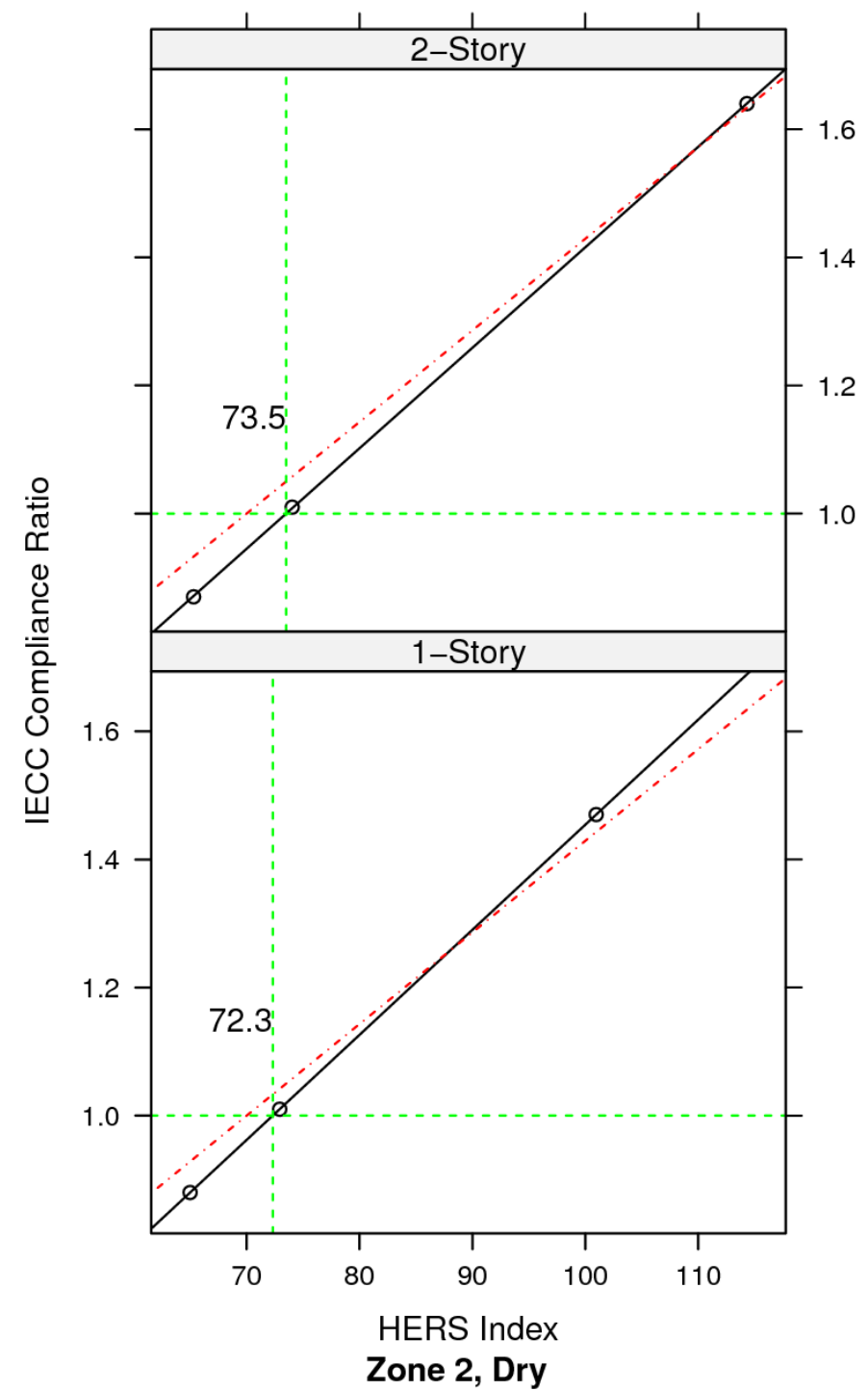

Figure A.3. Corresponding HERS Indexes for Climate Zone 2, Dry Regime (contd) 
Heat Pump Efficiency

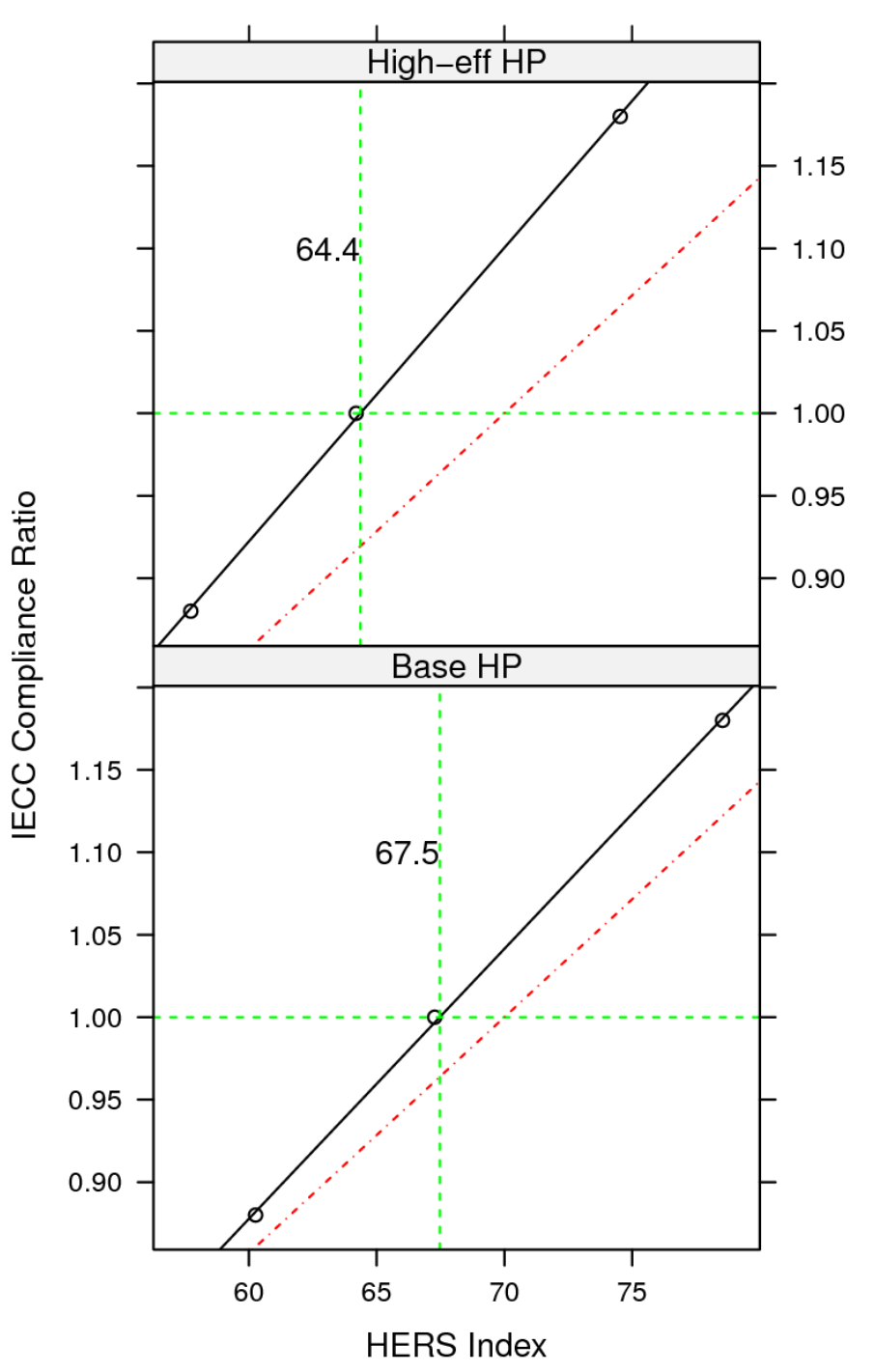

Zone 3, Moist
Gas Furnace \& AC Efficiency

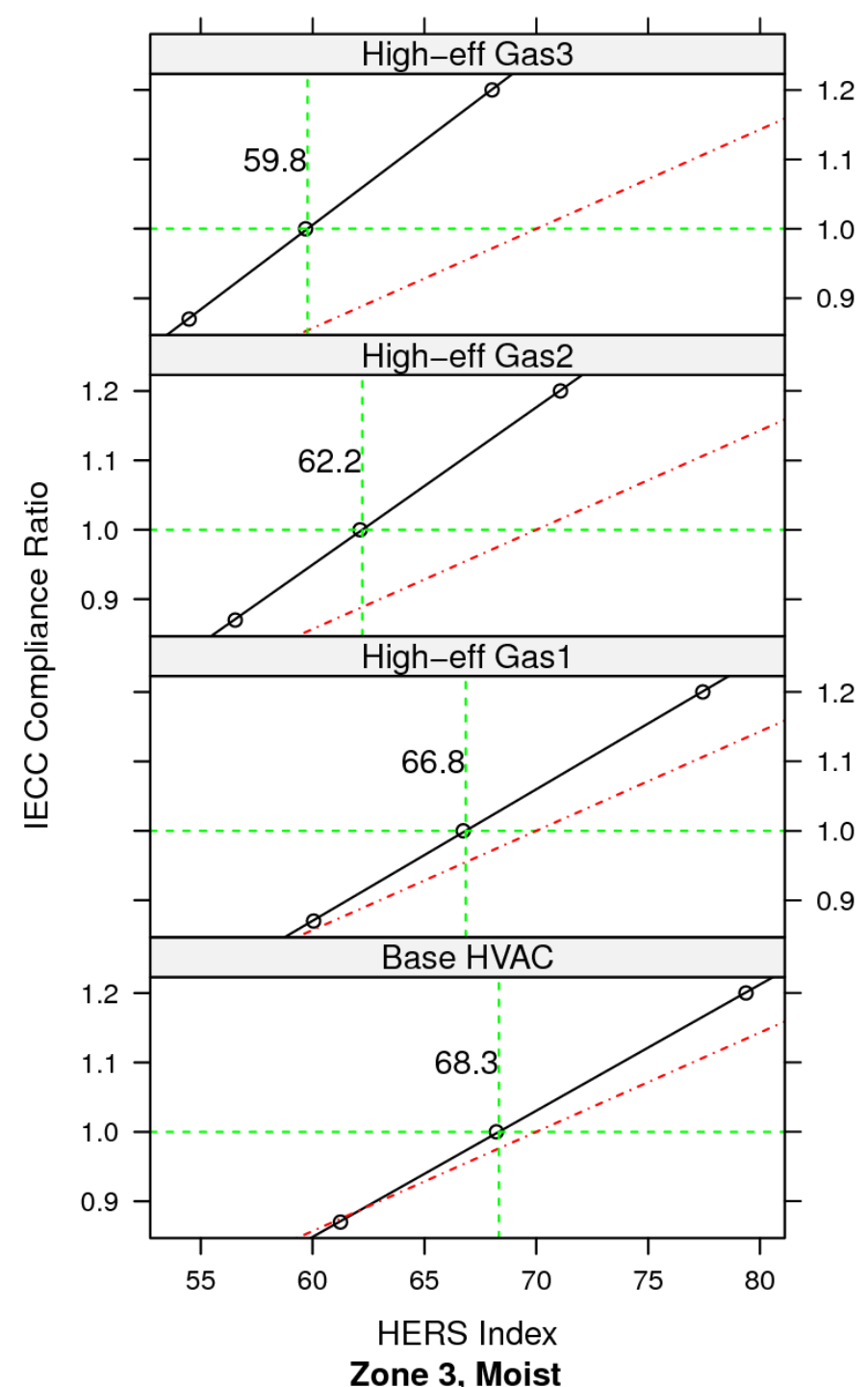

Figure A.4. Corresponding HERS Indexes for Climate Zone 3, Moist Regime 
Window-Floor Ratio

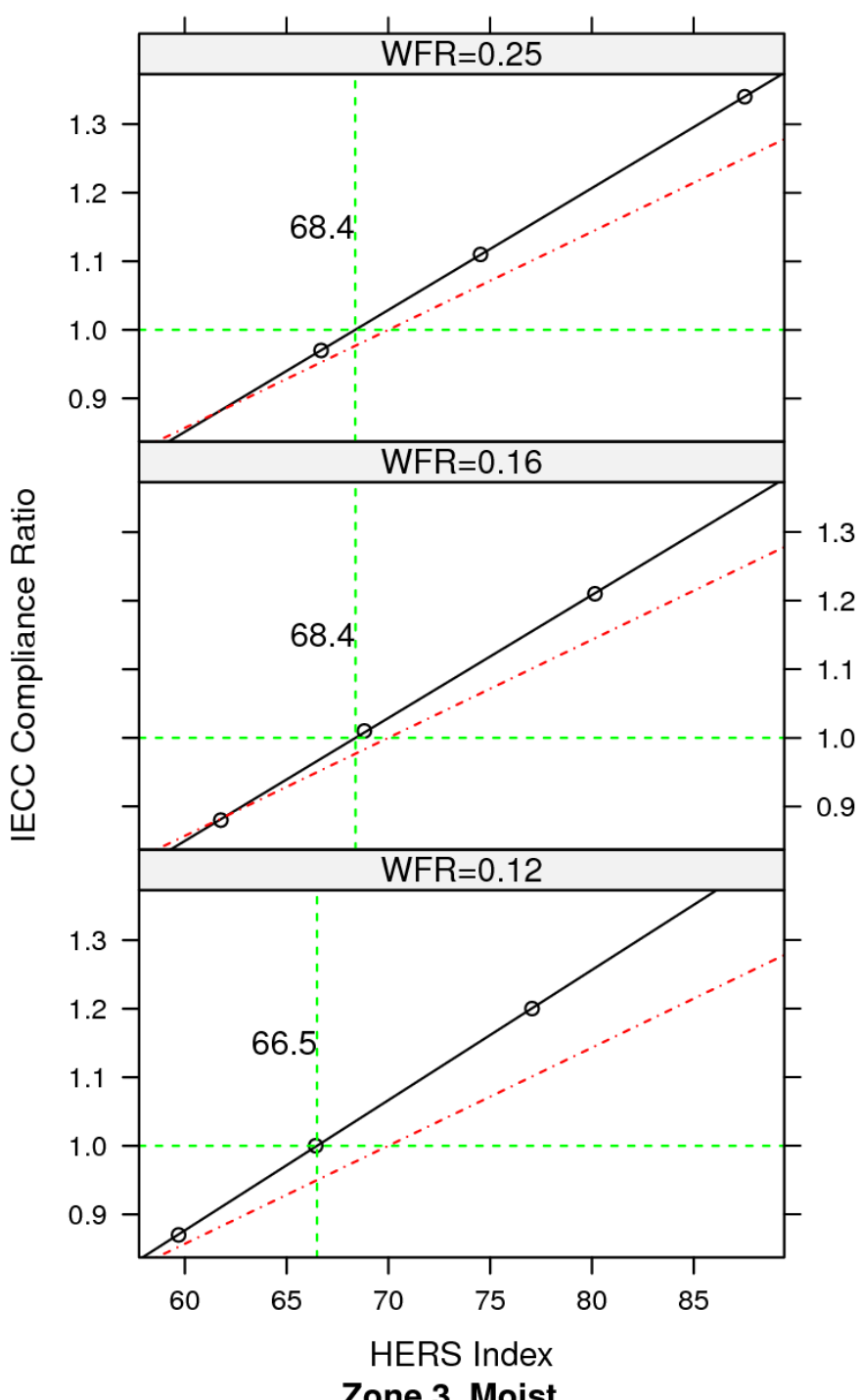

\section{Conditioned Floor Area}

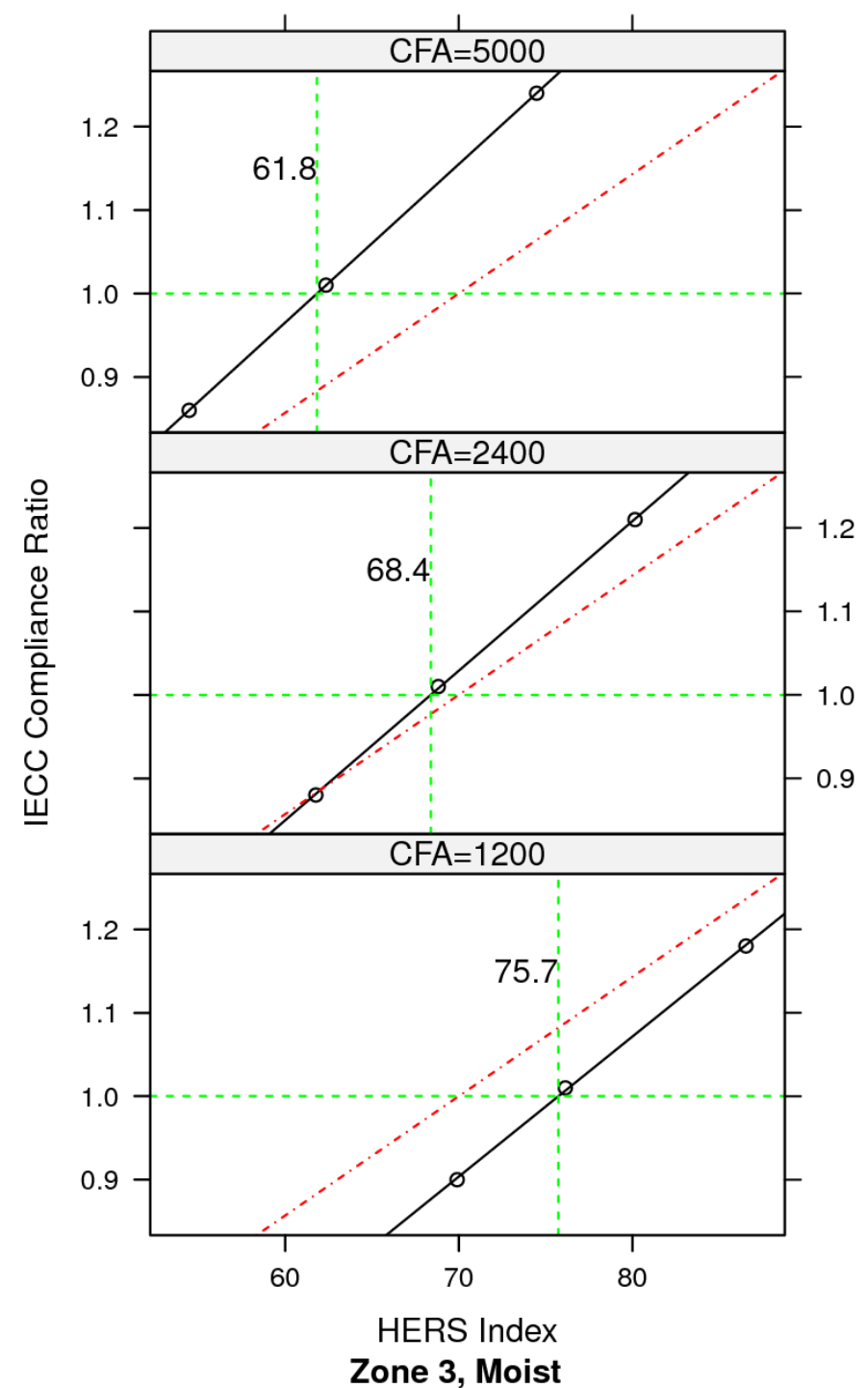

Figure A.4. Corresponding HERS Indexes for Climate Zone 3, Moist Regime (contd) 
Foundation

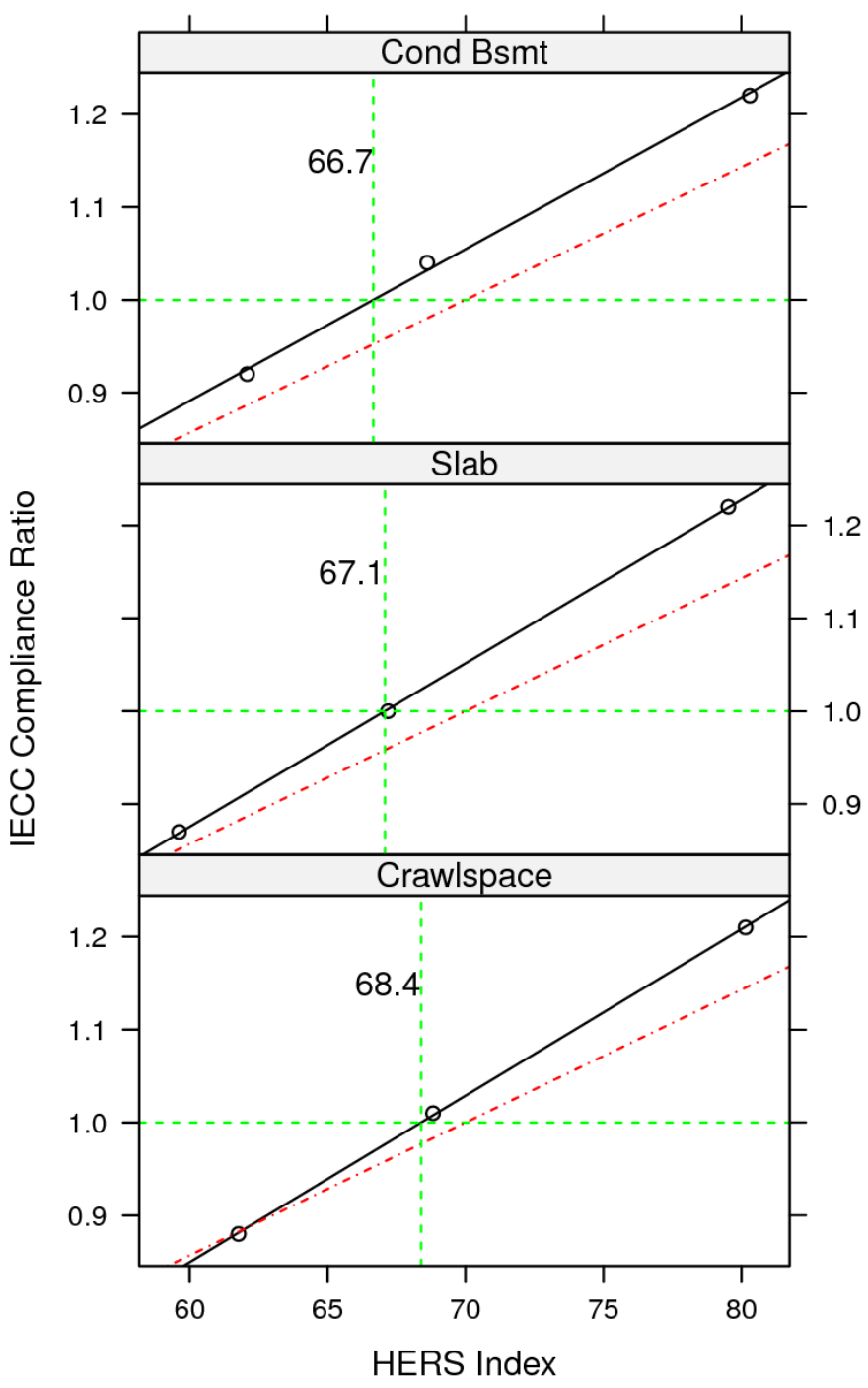

Zone 3, Moist
Appliances

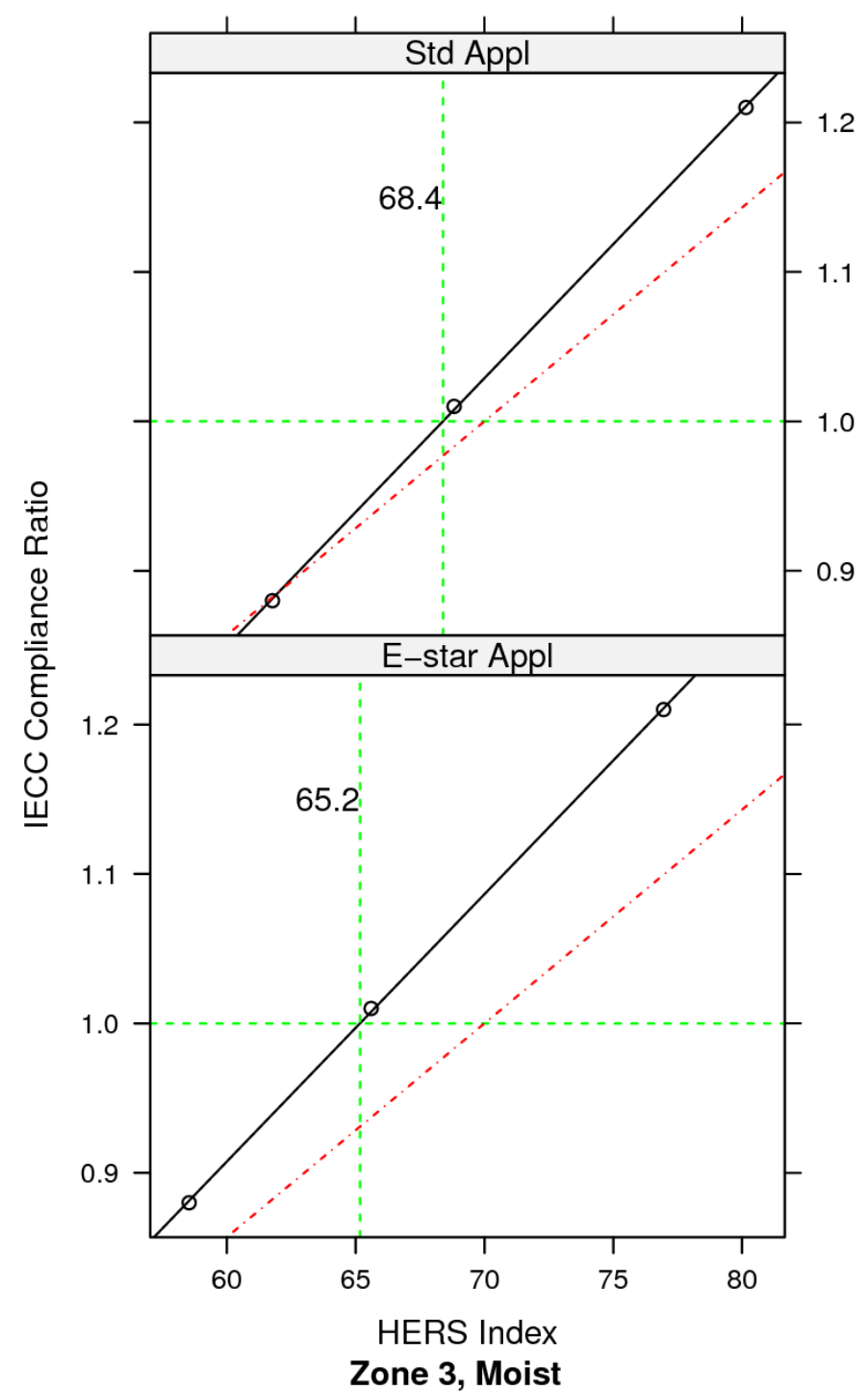

Figure A.4. Corresponding HERS Indexes for Climate Zone 3, Moist Regime (contd) 


\section{Glazing Orientation}

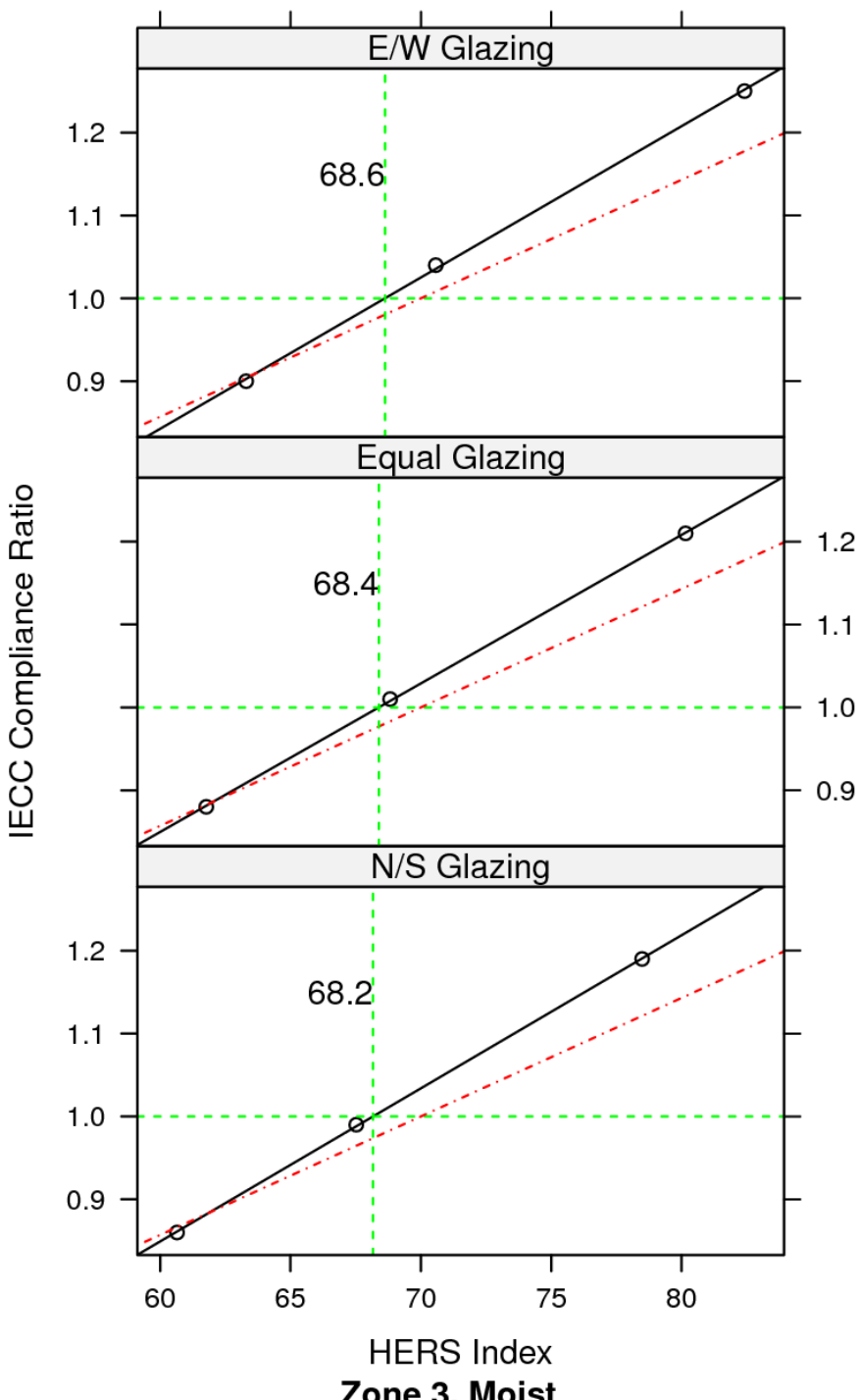

Number of Stories

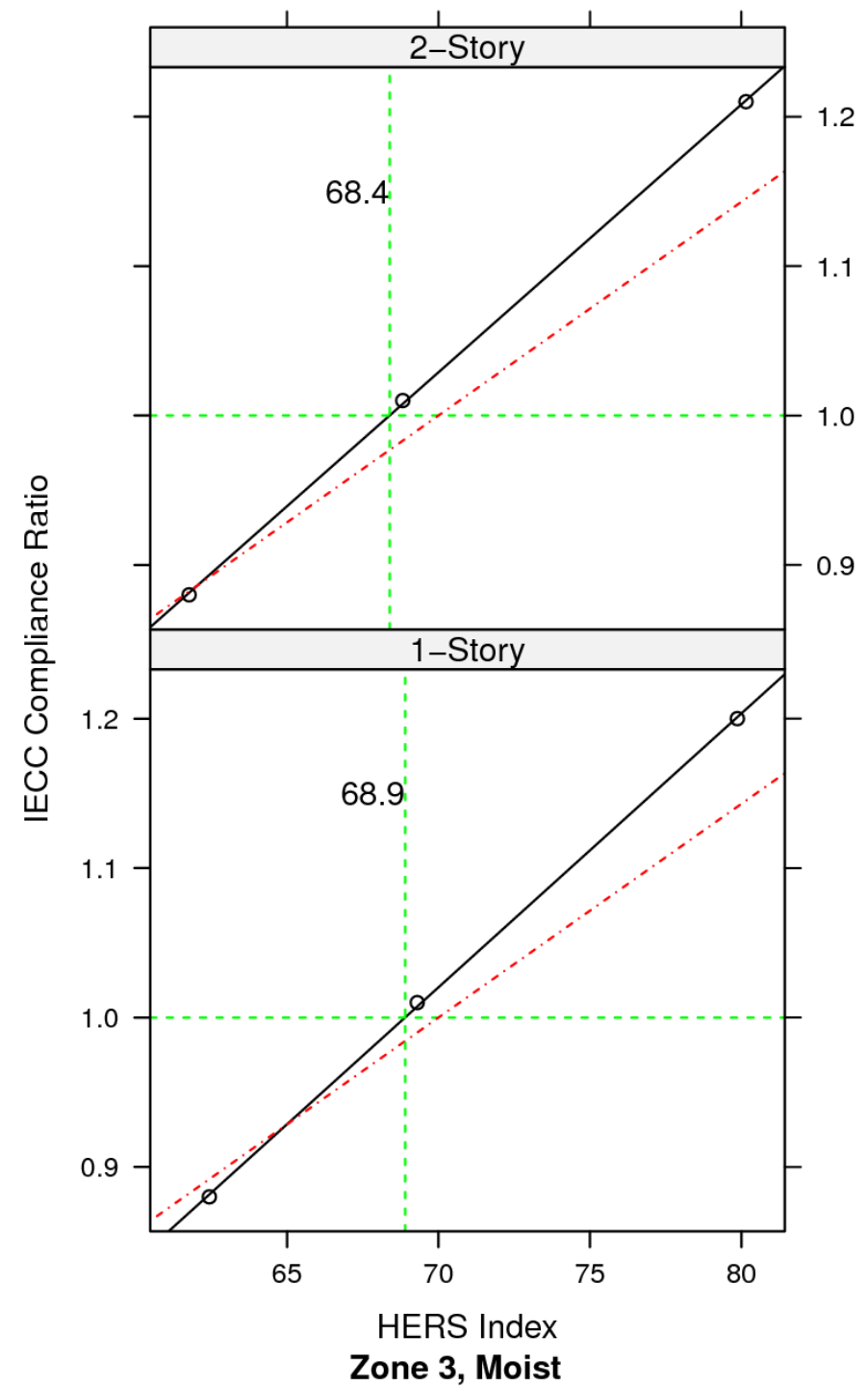

Figure A.4. Corresponding HERS Indexes for Climate Zone 3, Moist Regime (contd) 
Heat Pump Efficiency

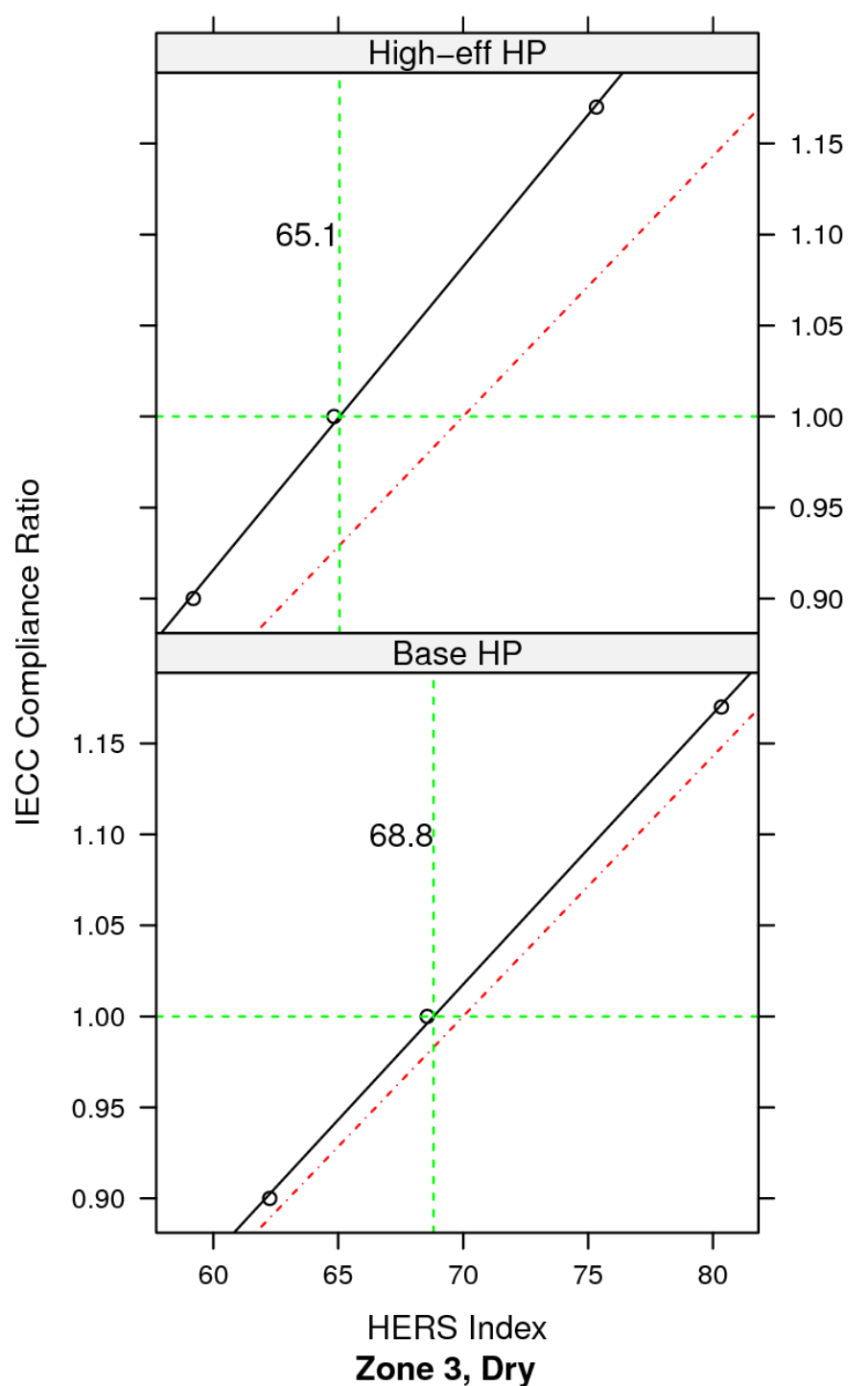

Gas Furnace \& AC Efficiency

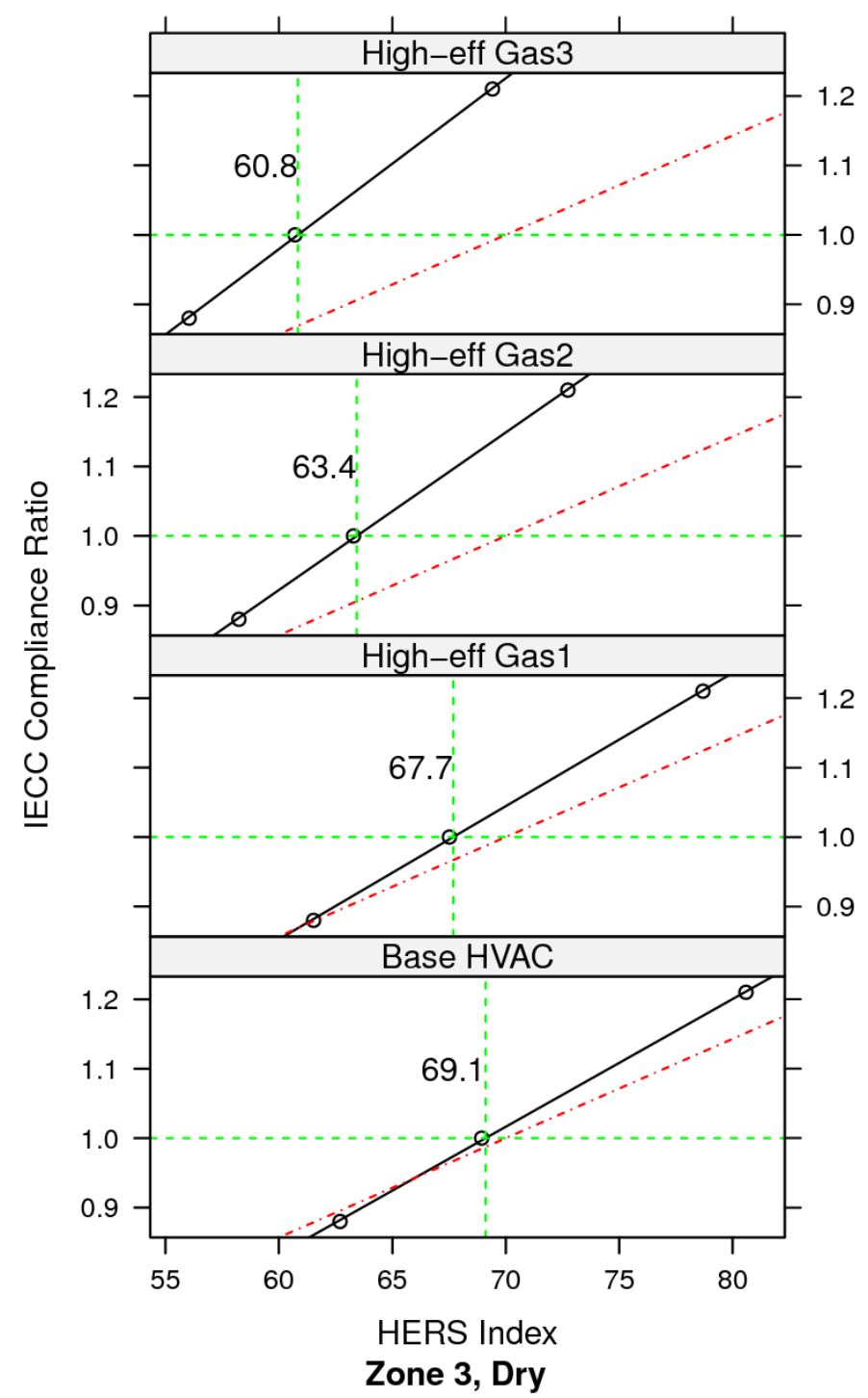

Figure A.5. Corresponding HERS Indexes for Climate Zone 3, Dry Regime 
Window-Floor Ratio

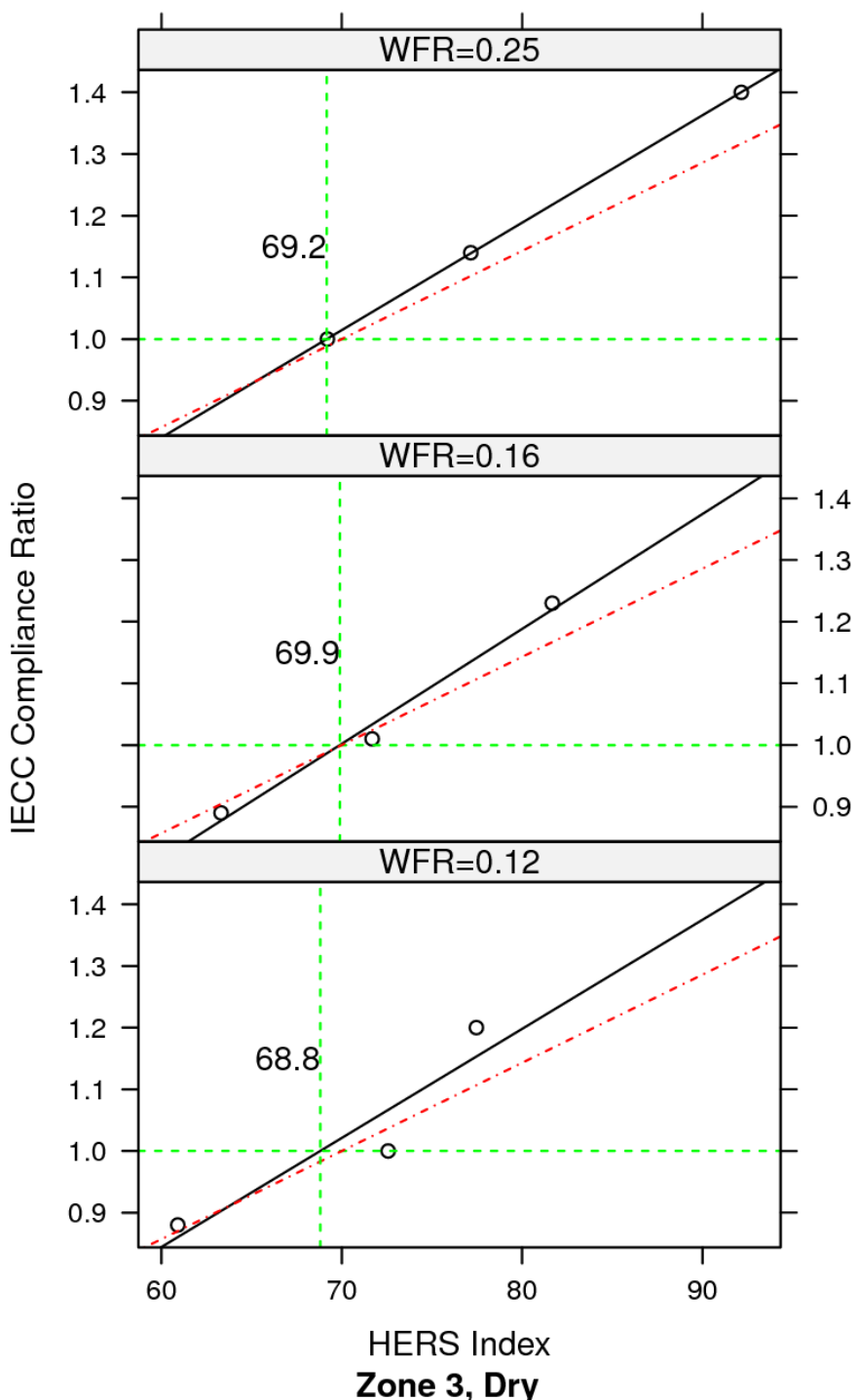

Conditioned Floor Area

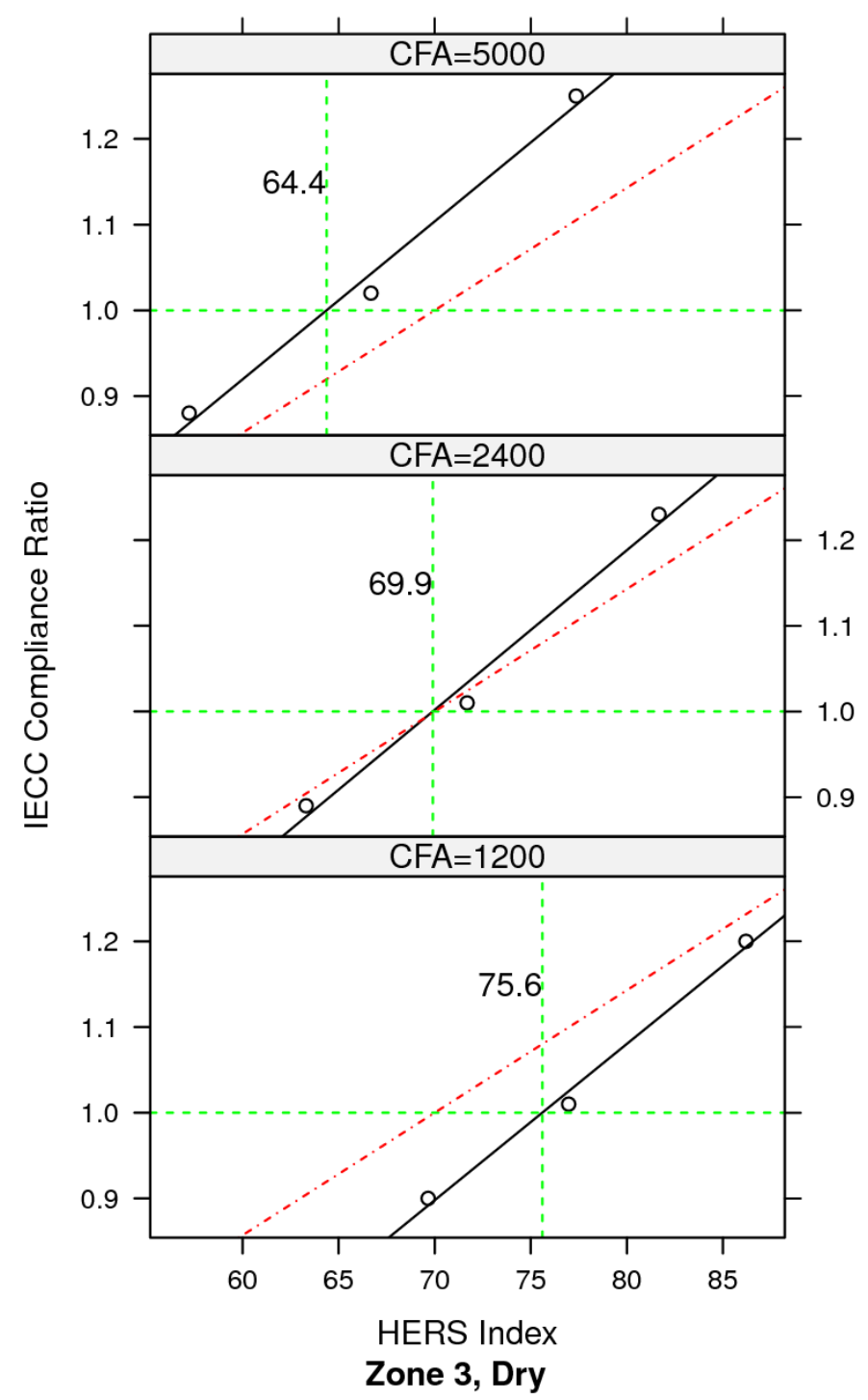

Figure A.5. Corresponding HERS Indexes for Climate Zone 3, Dry Regime (contd) 
Foundation

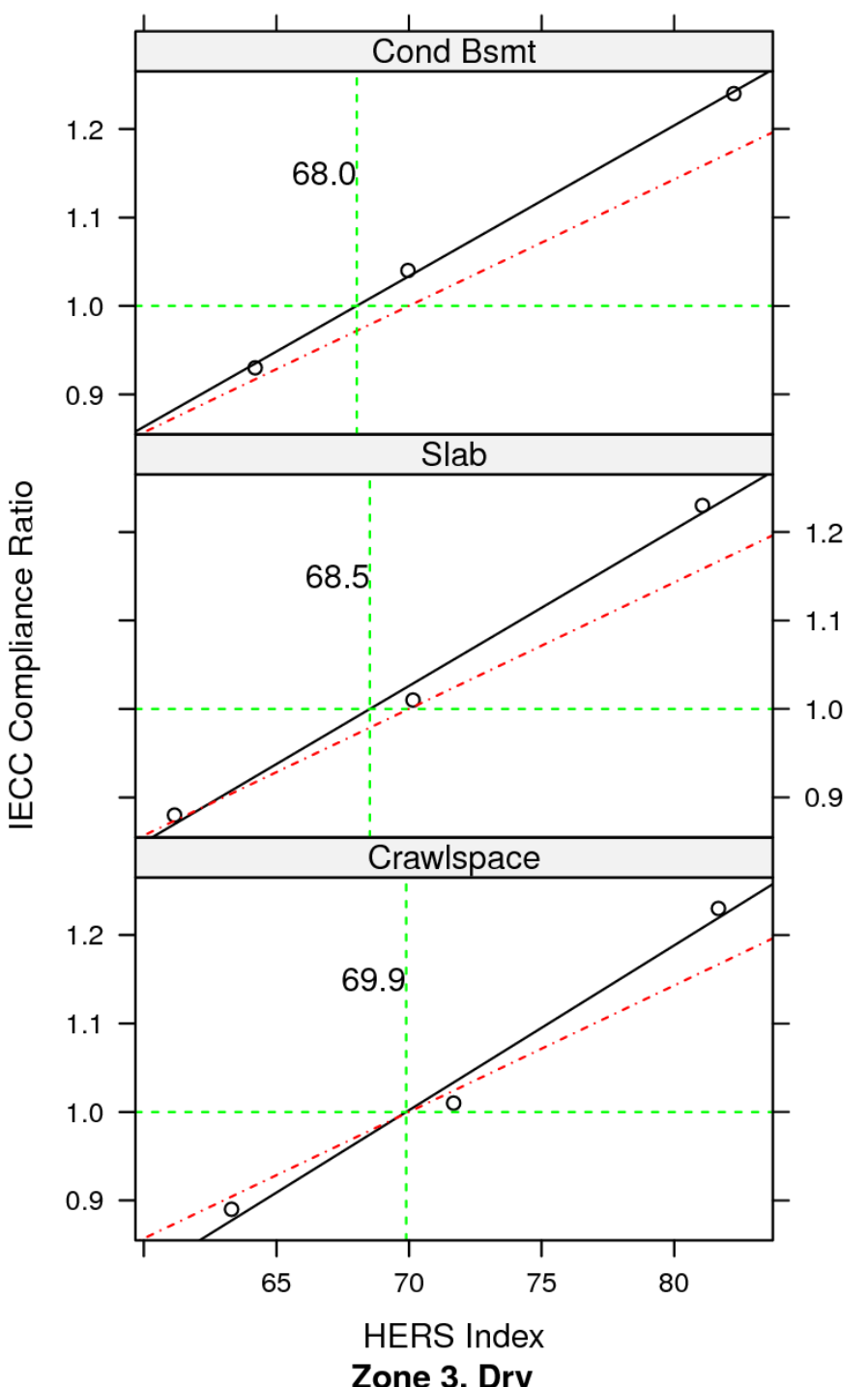

Appliances

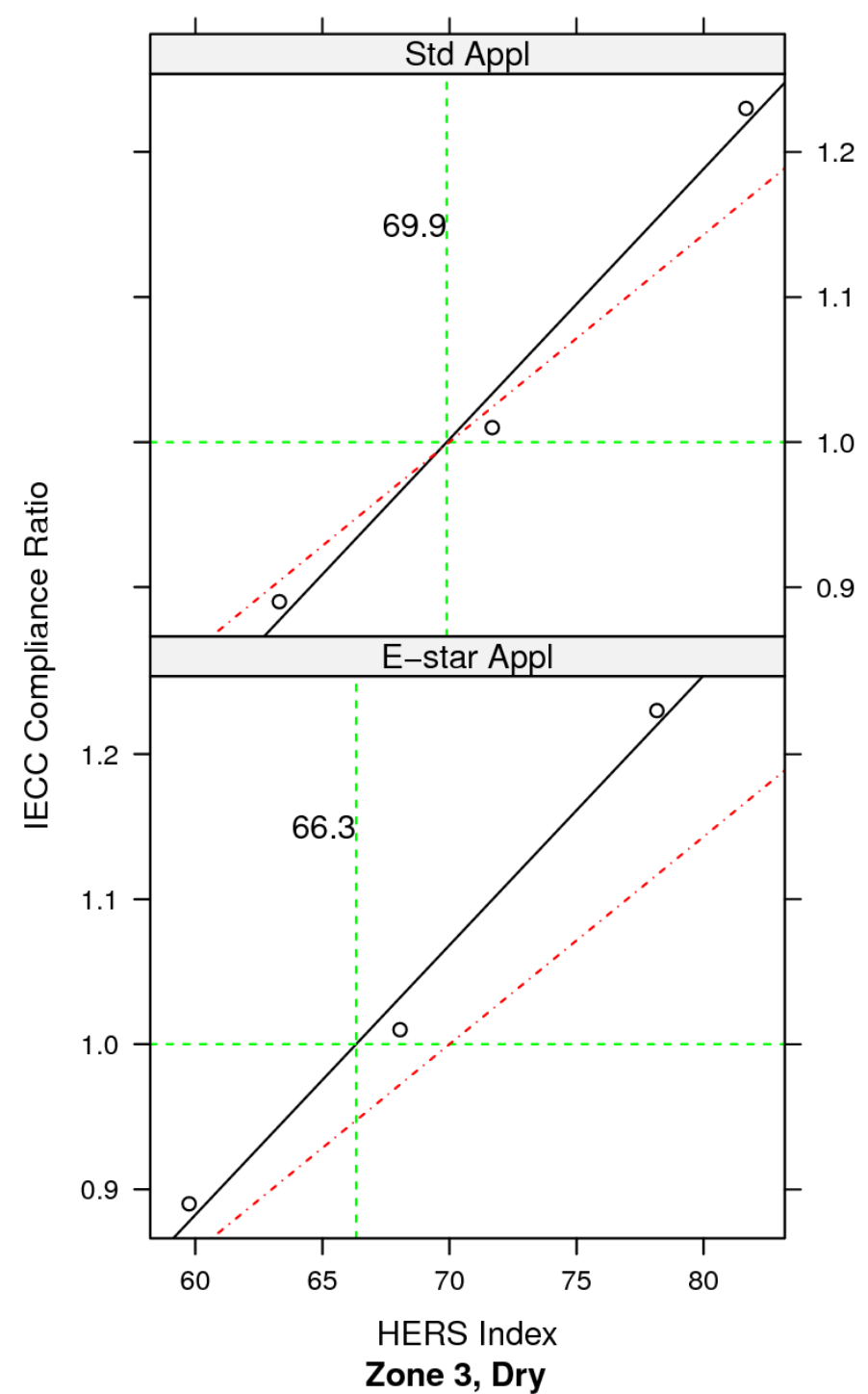

Figure A.5. Corresponding HERS Indexes for Climate Zone 3, Dry Regime (contd) 


\section{Glazing Orientation}

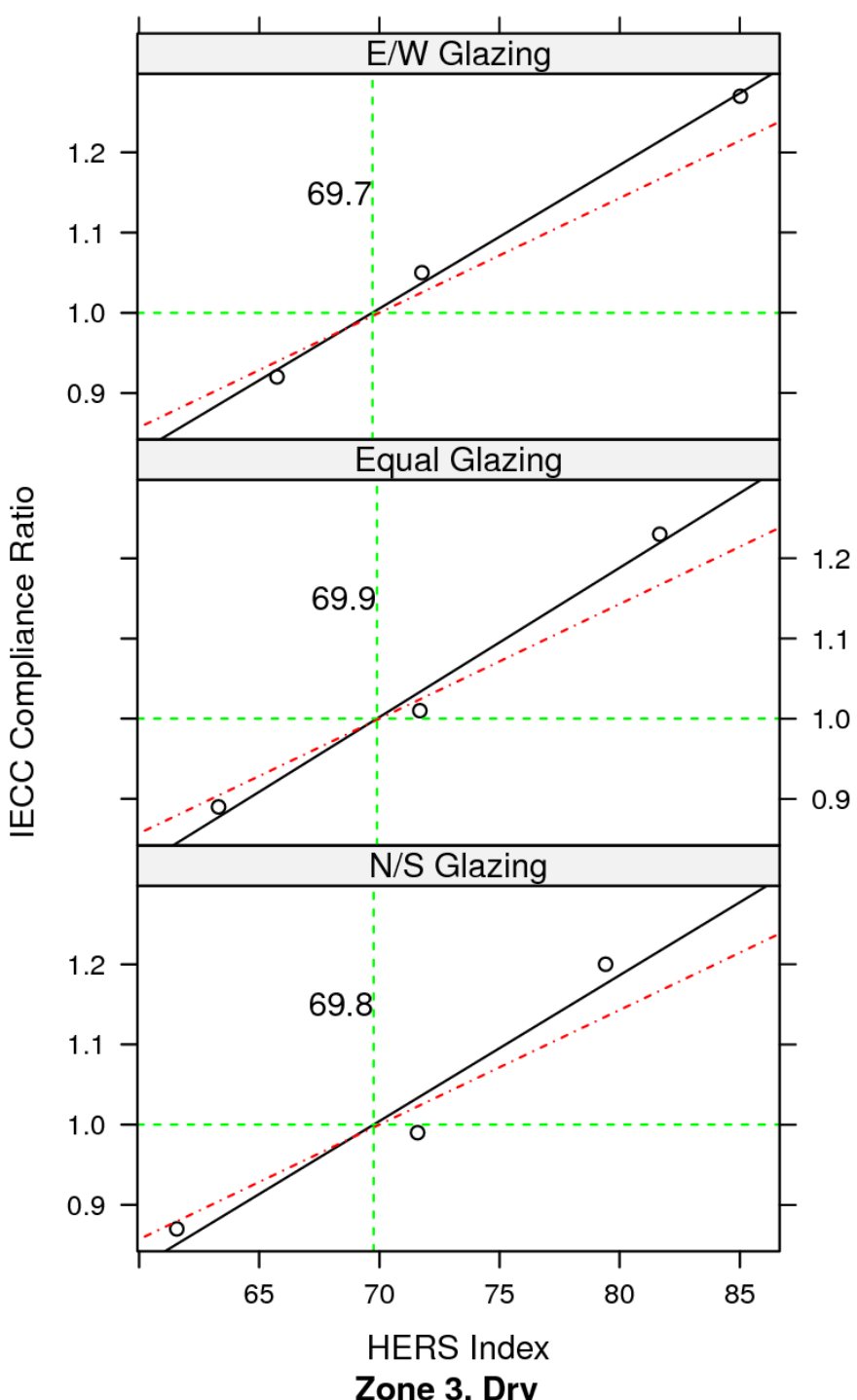

Number of Stories

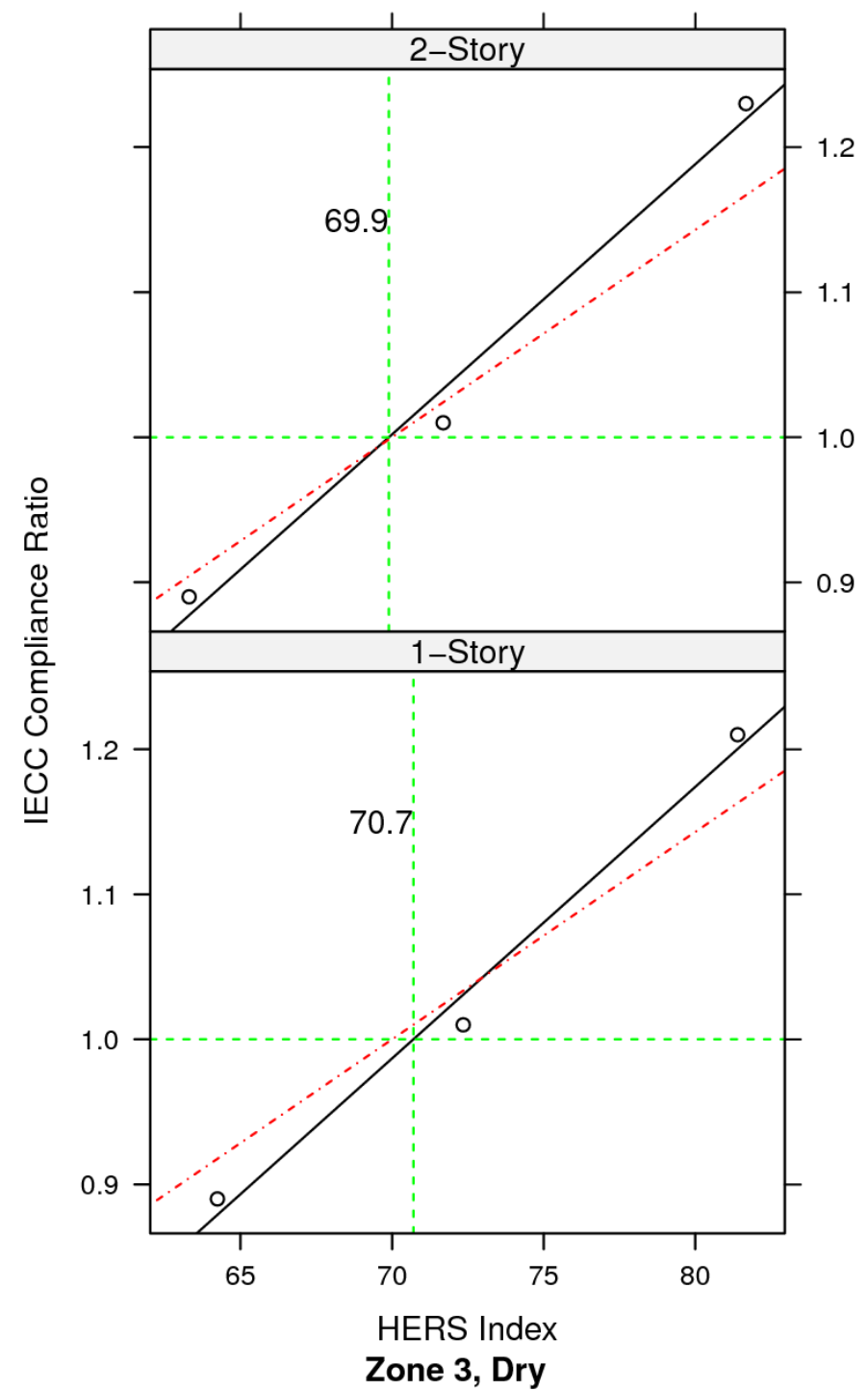

Figure A.5. Corresponding HERS Indexes for Climate Zone 3, Dry Regime (contd) 
Heat Pump Efficiency

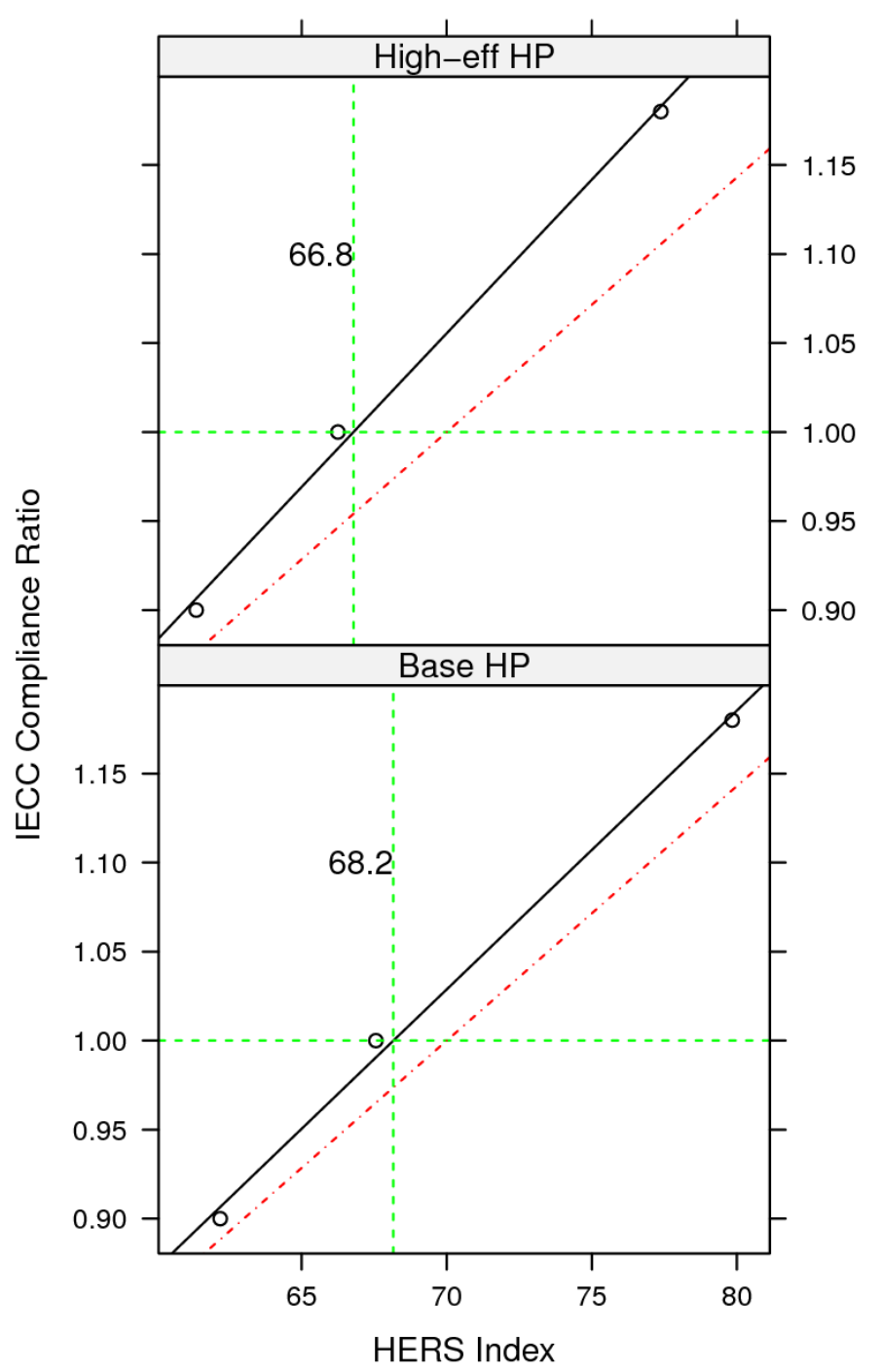

Zone 3, Marine
Gas Furnace \& AC Efficiency

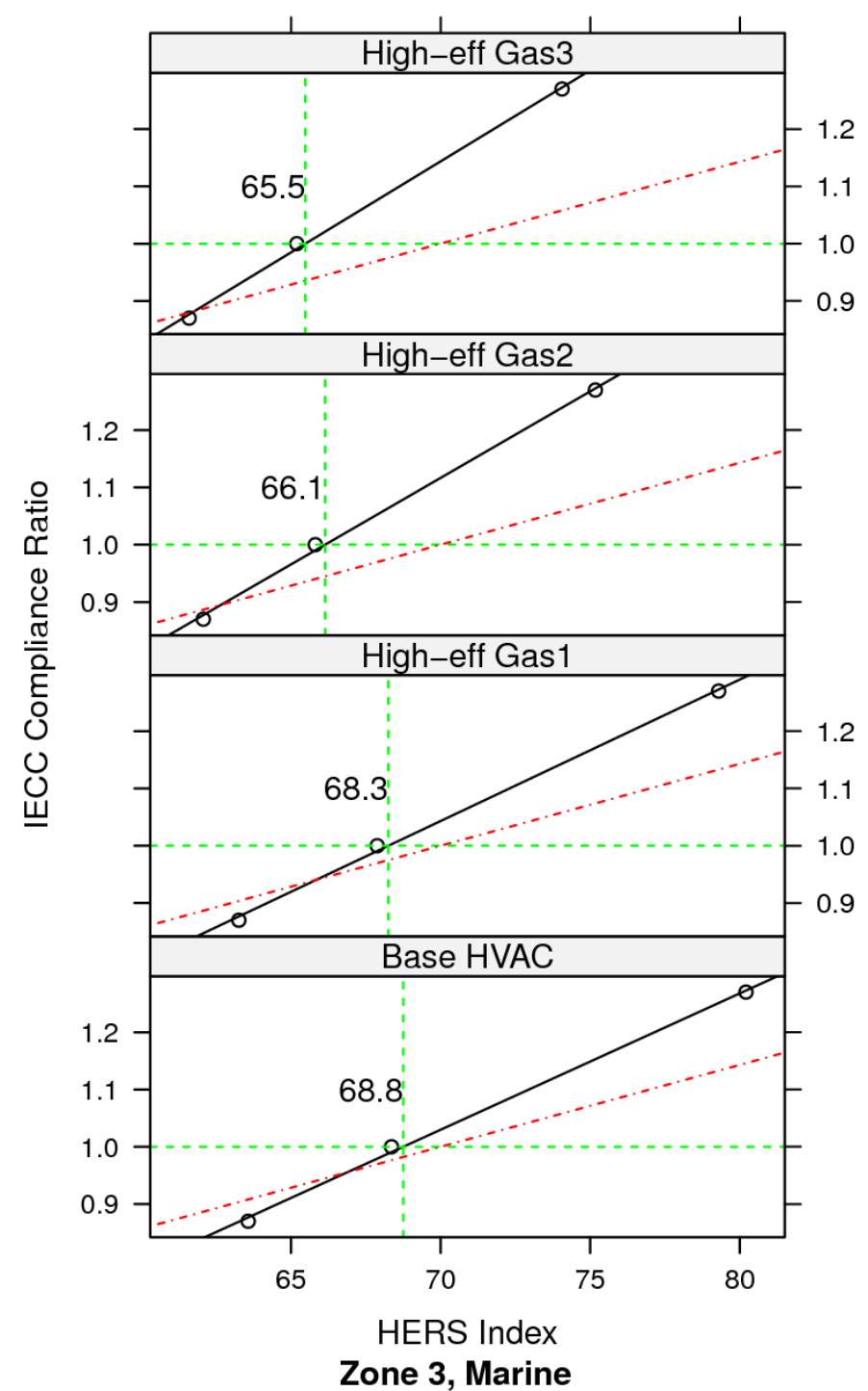

Figure A.6. Corresponding HERS Indexes for Climate Zone 3, Marine Regime 
Window-Floor Ratio

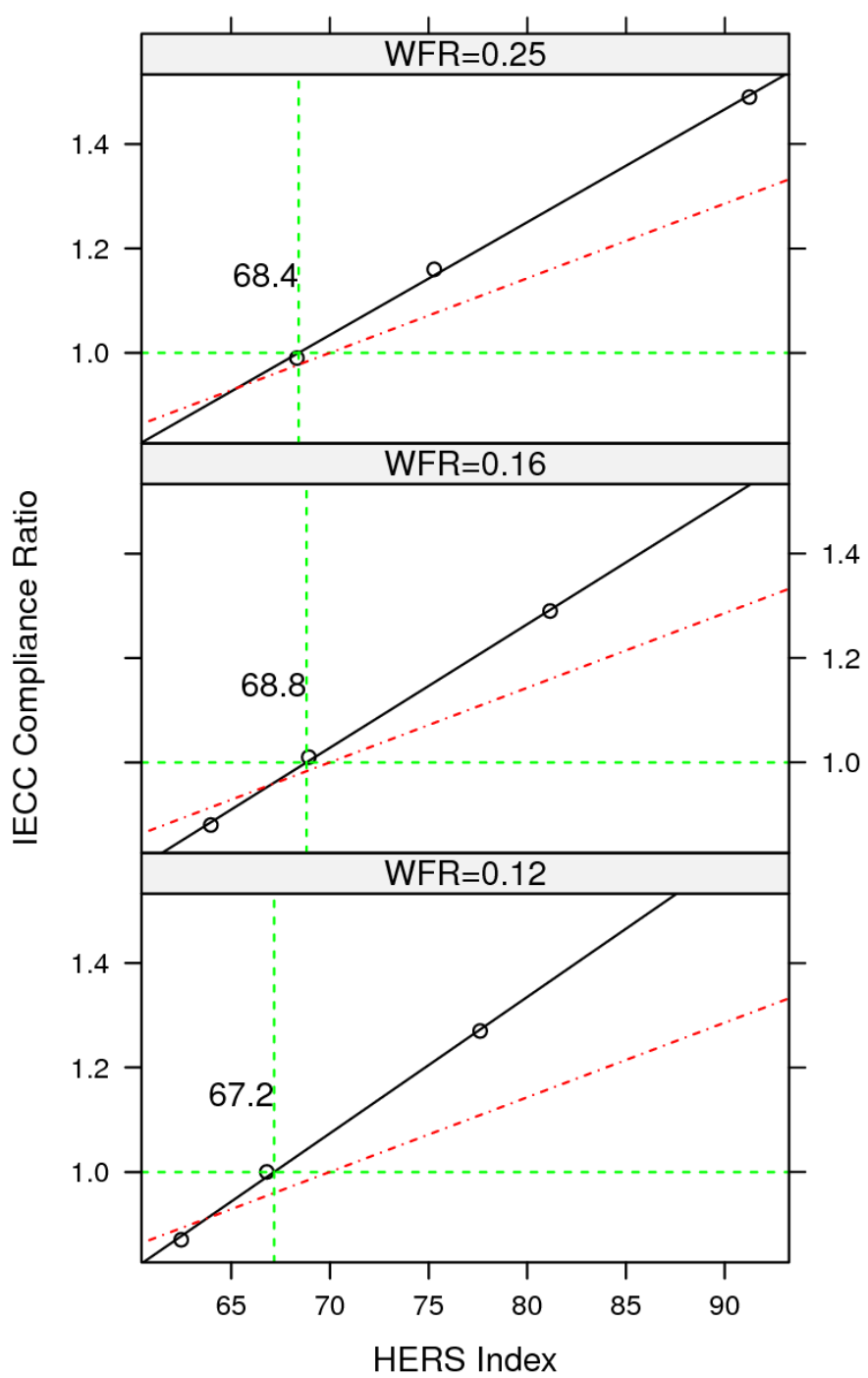

Zone 3, Marine

\section{Conditioned Floor Area}

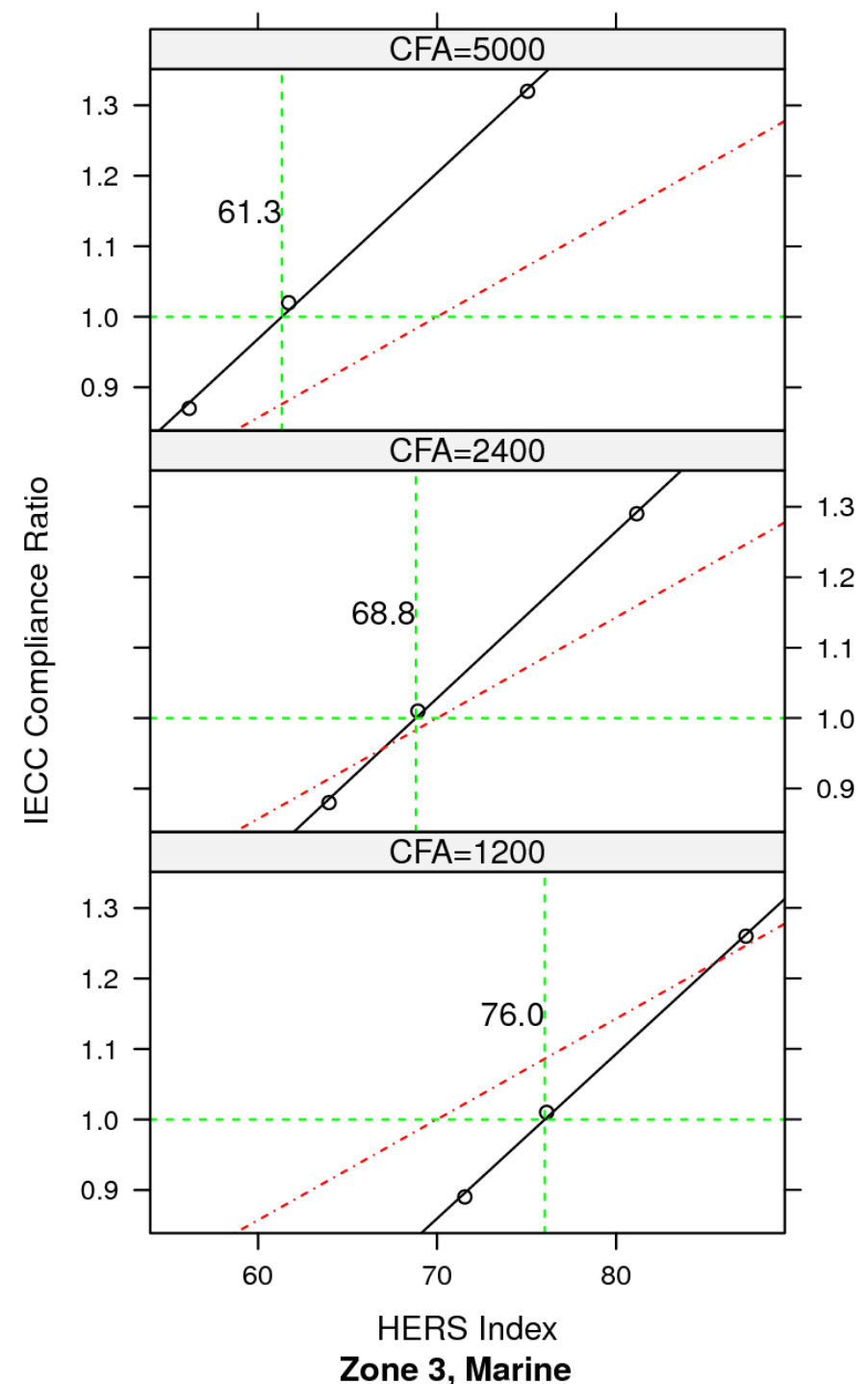

Figure A.6. Corresponding HERS Indexes for Climate Zone 3, Marine Regime (contd) 
Foundation

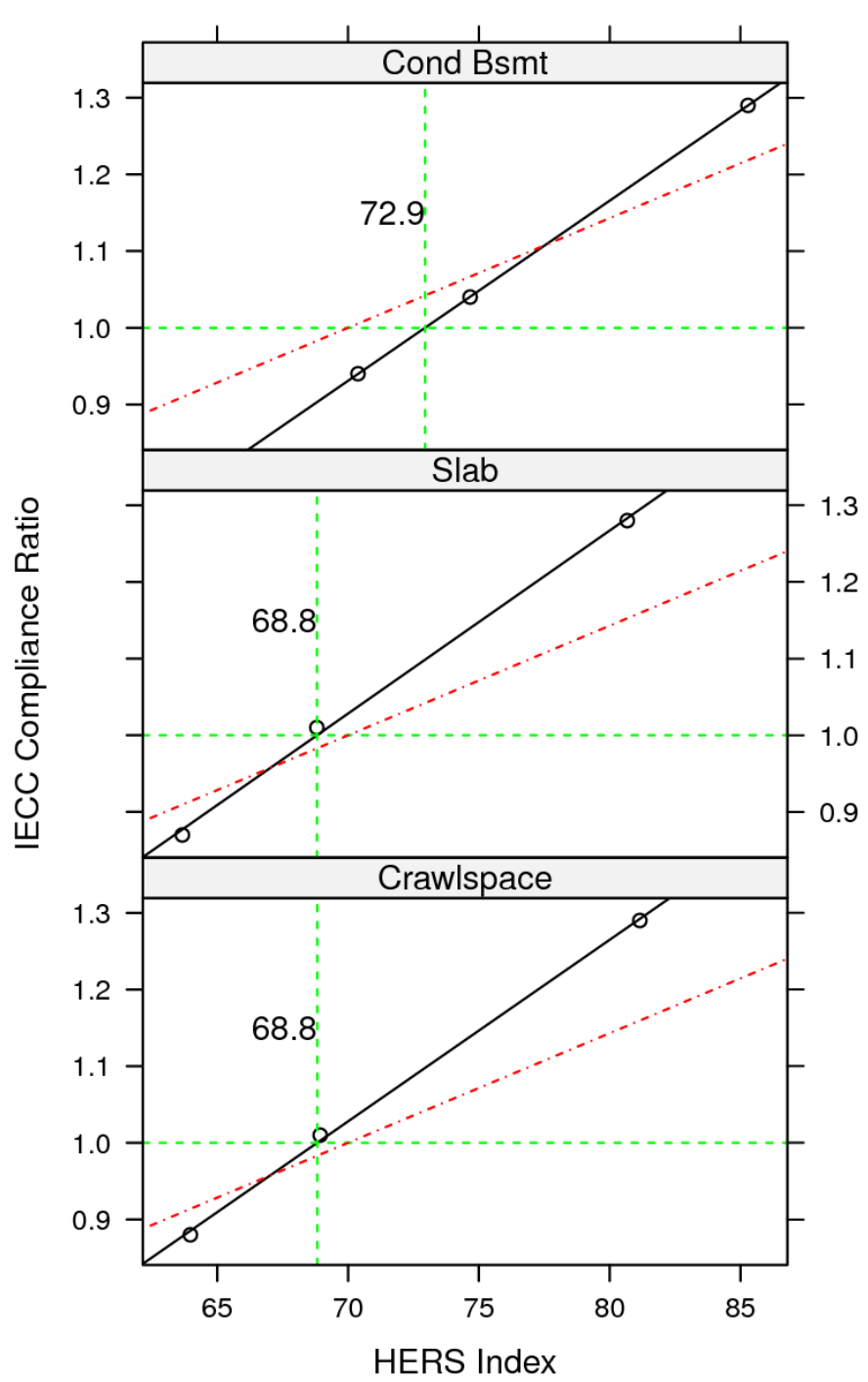

Zone 3, Marine

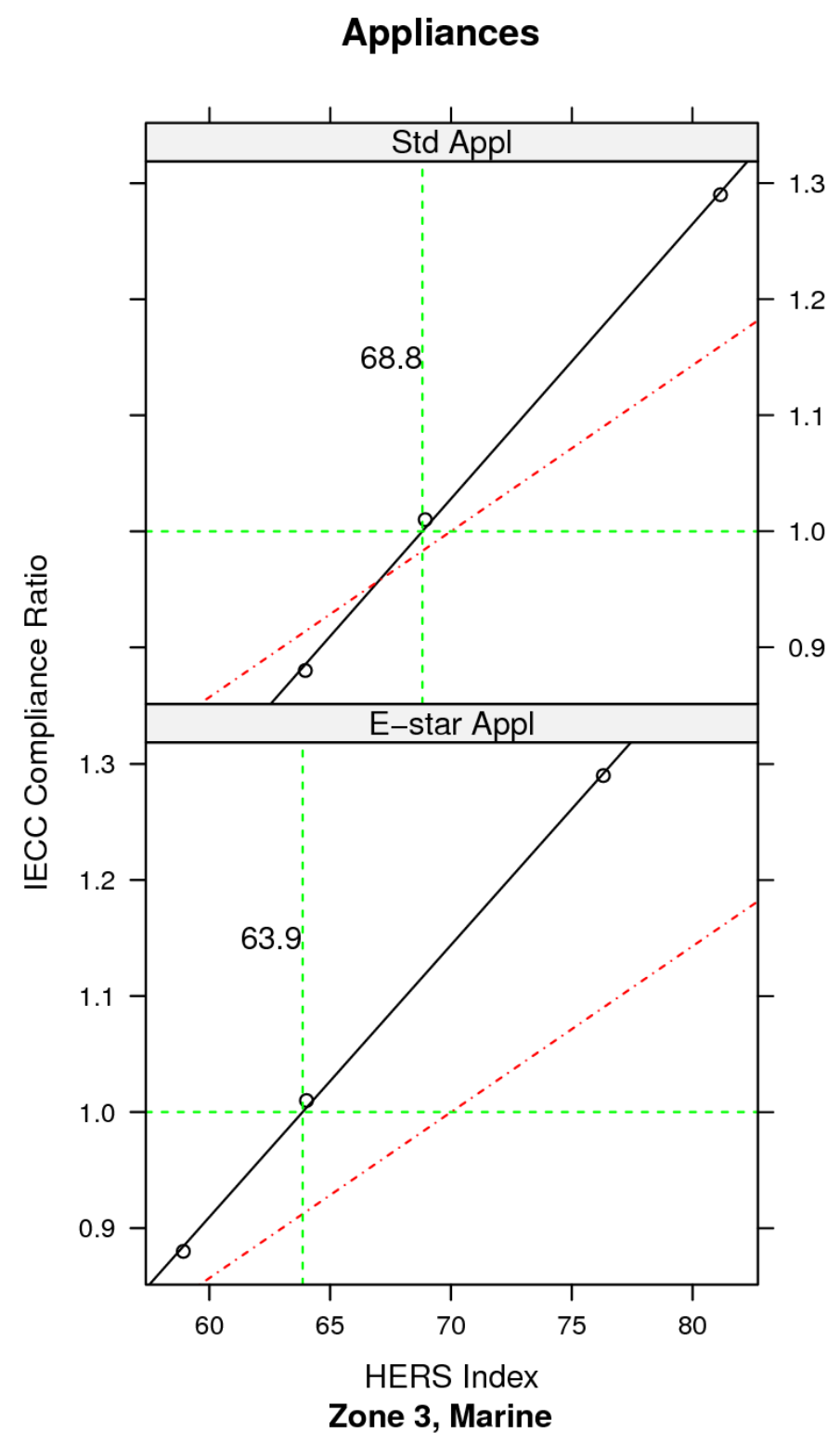

Zone 3, Marine

Figure A.6. Corresponding HERS Indexes for Climate Zone 3, Marine Regime (contd) 


\section{Glazing Orientation}

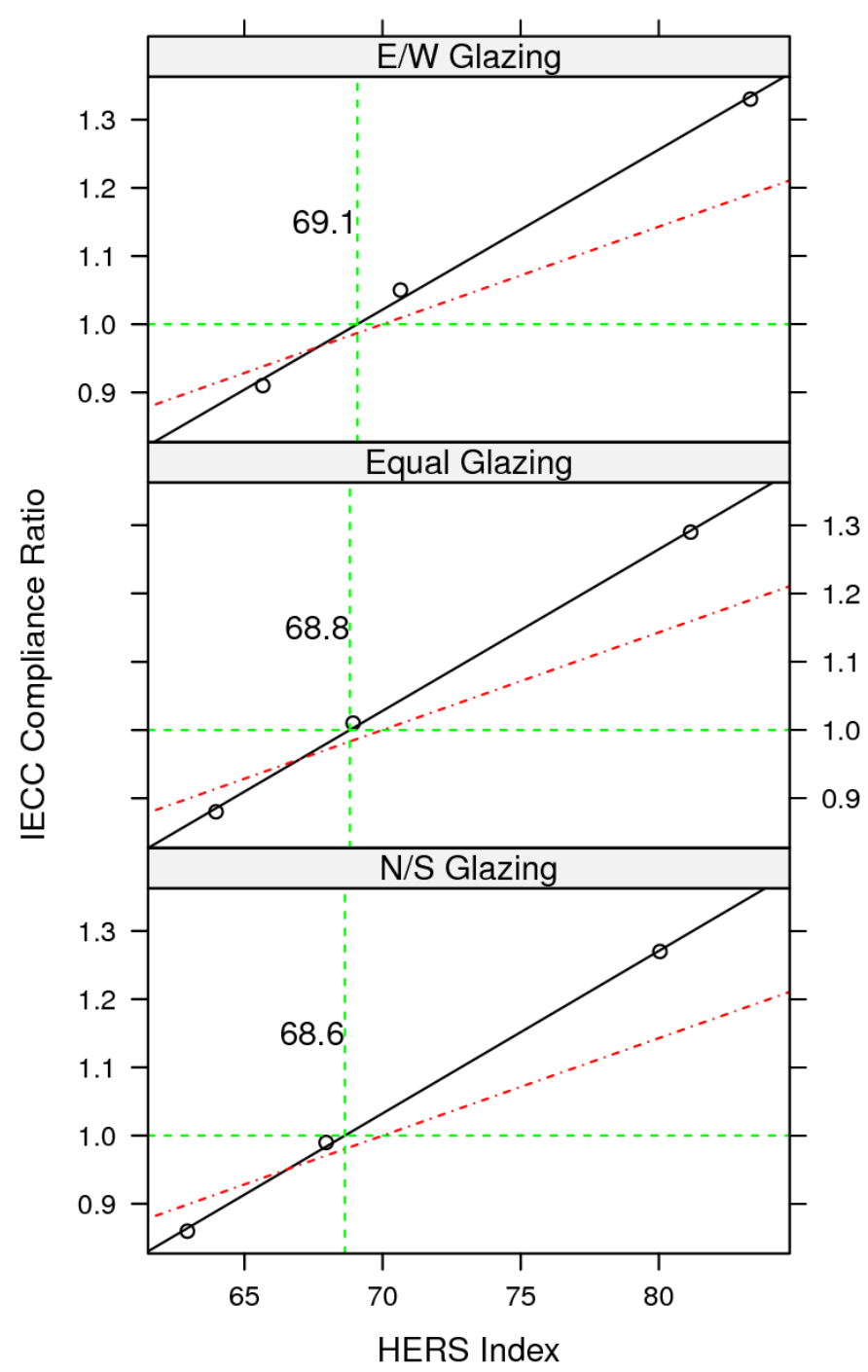

Zone 3, Marine

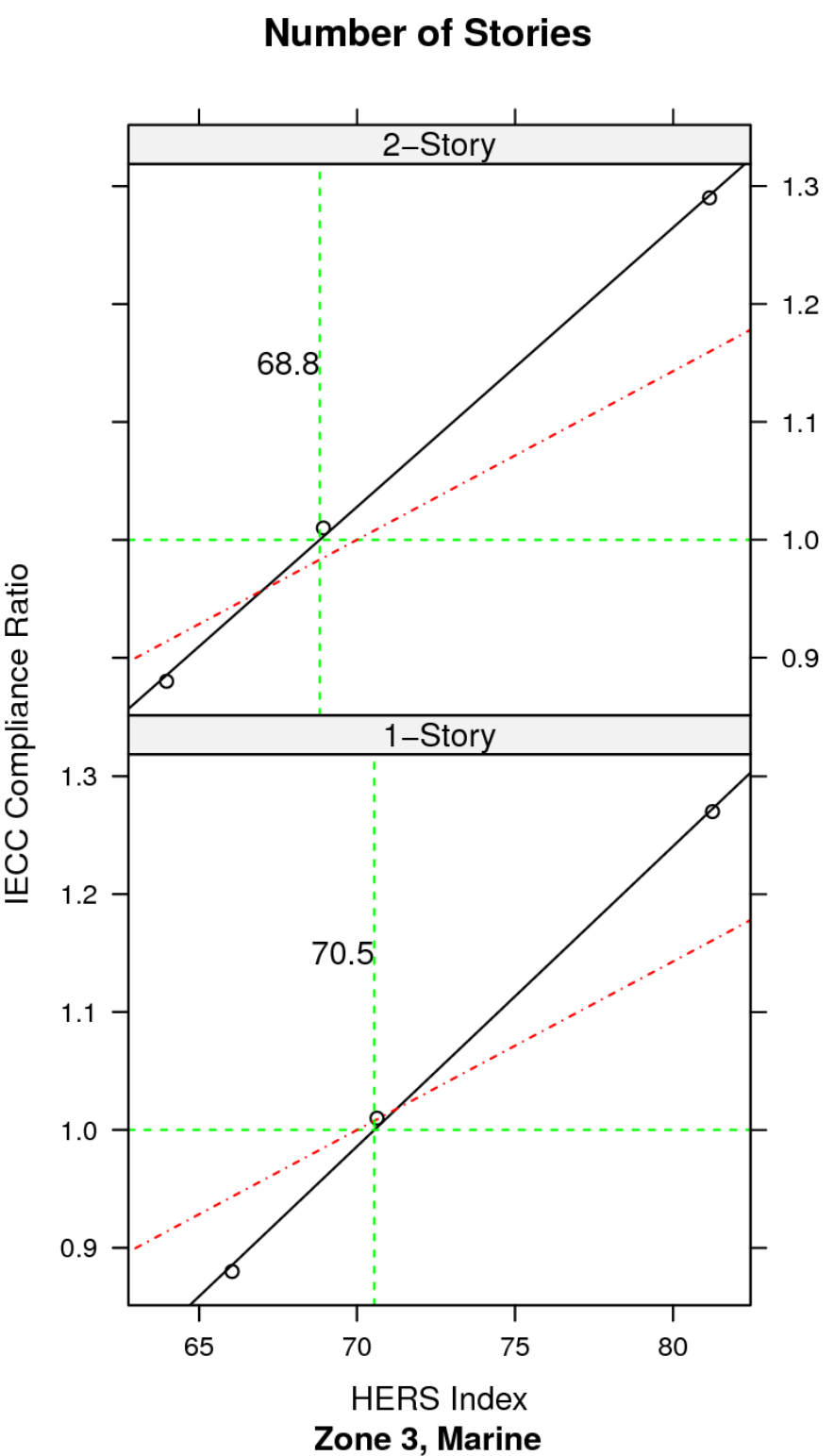

Figure A.6. Corresponding HERS Indexes for Climate Zone 3, Marine Regime (contd) 
Heat Pump Efficiency

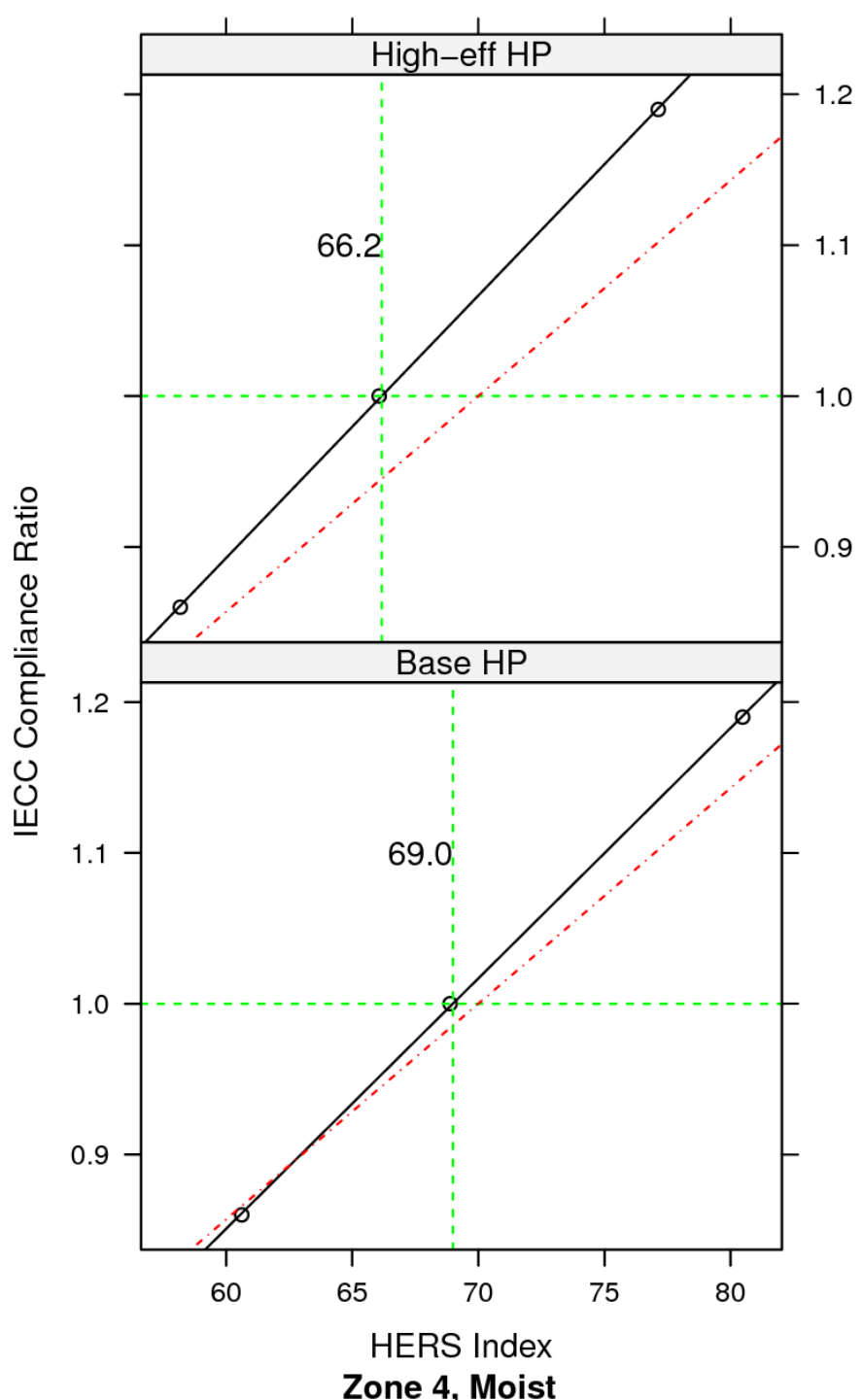

Gas Furnace \& AC Efficiency

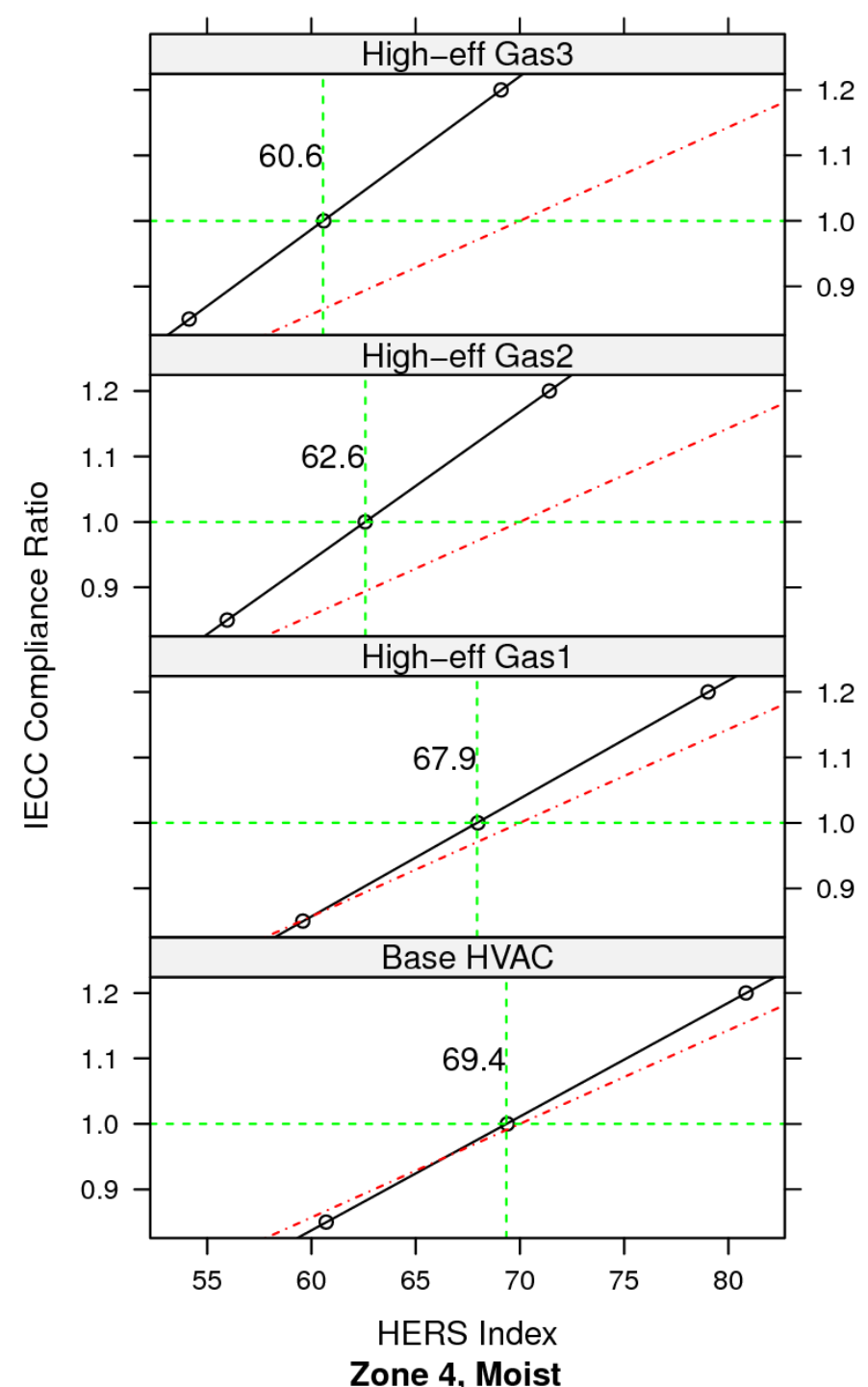

Figure A.7. Corresponding HERS Indexes for Climate Zone 4, Moist Regime 
Window-Floor Ratio

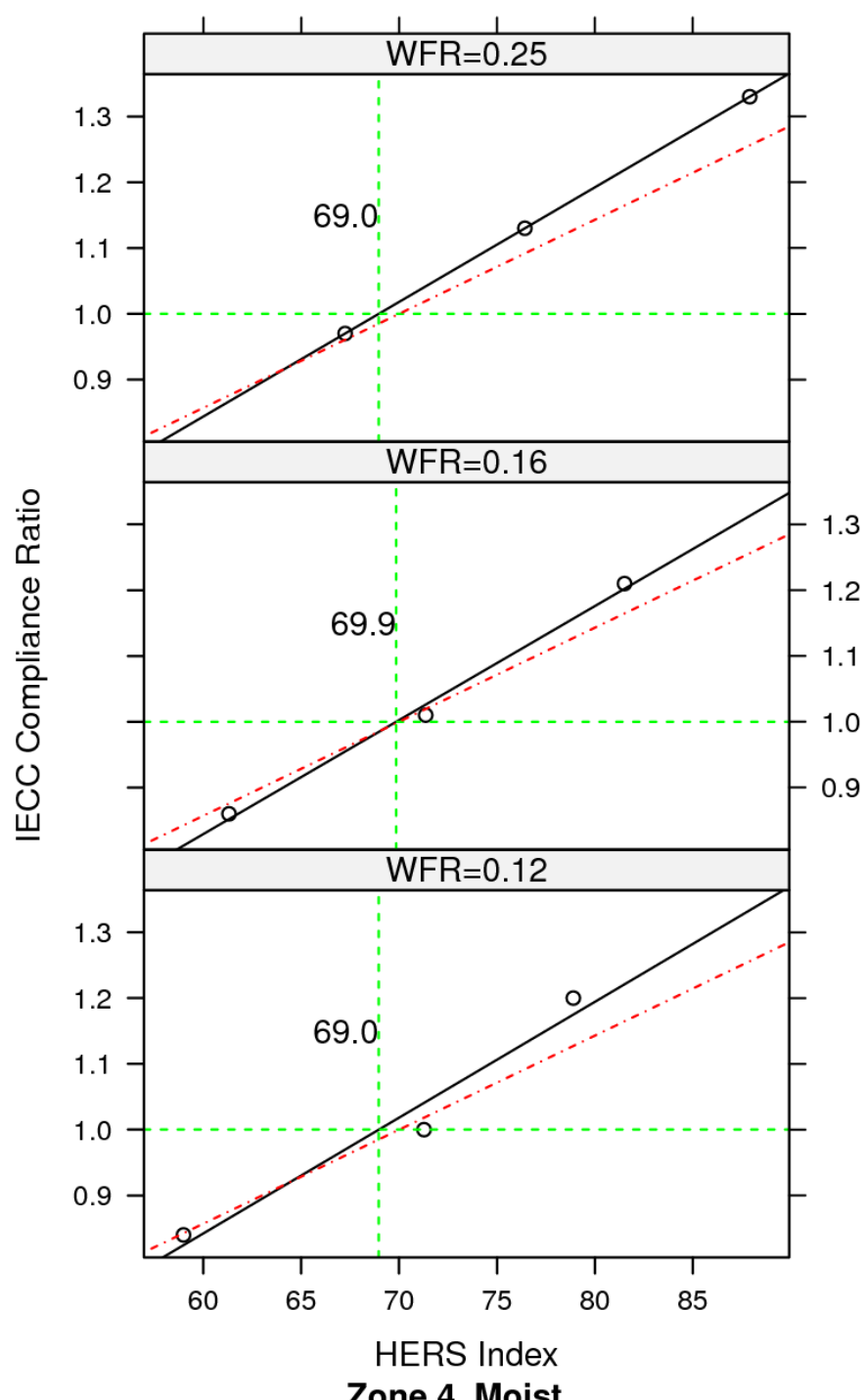

\section{Conditioned Floor Area}

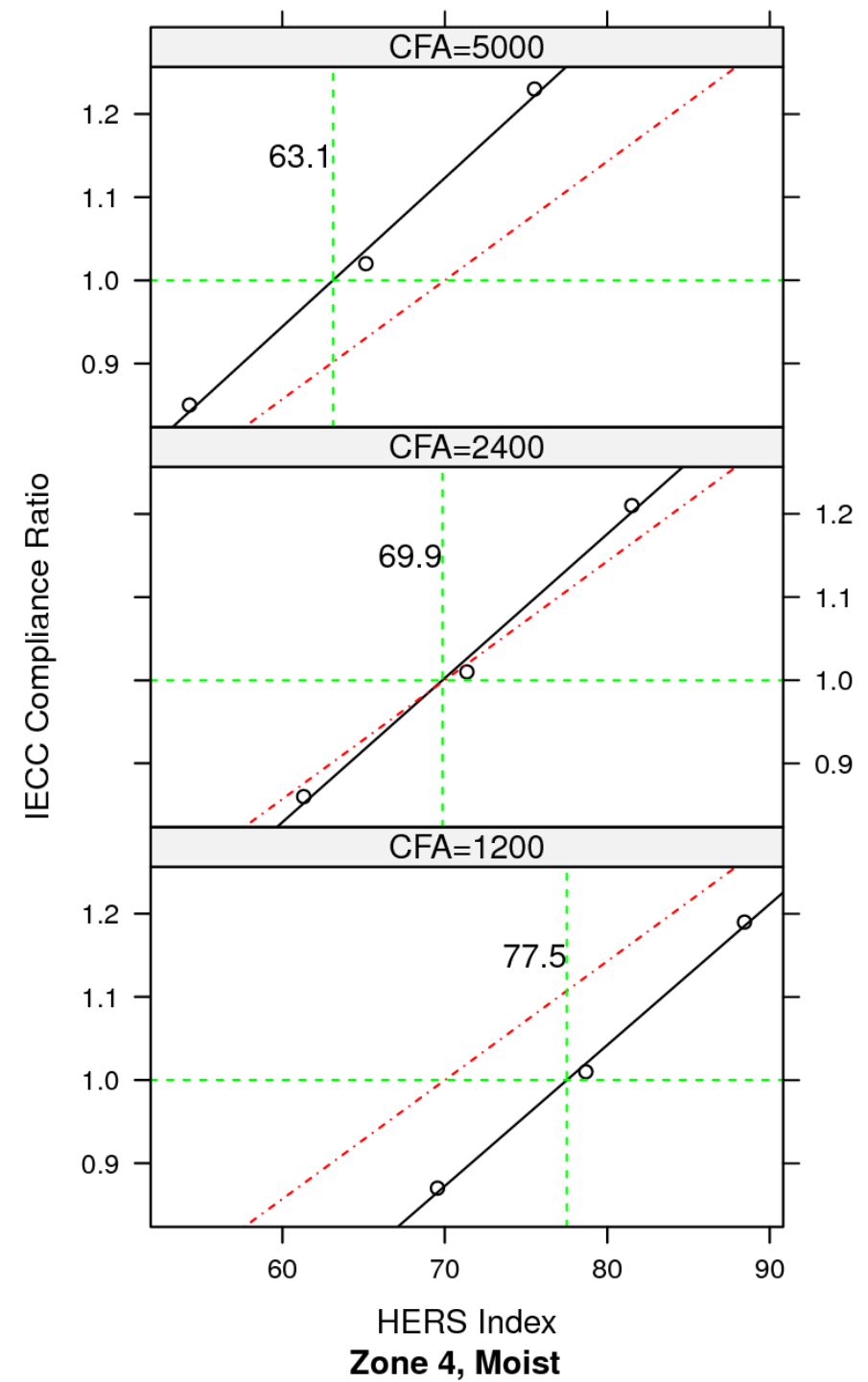

Figure A.7. Corresponding HERS Indexes for Climate Zone 4, Moist Regime (contd) 


\section{Foundation}

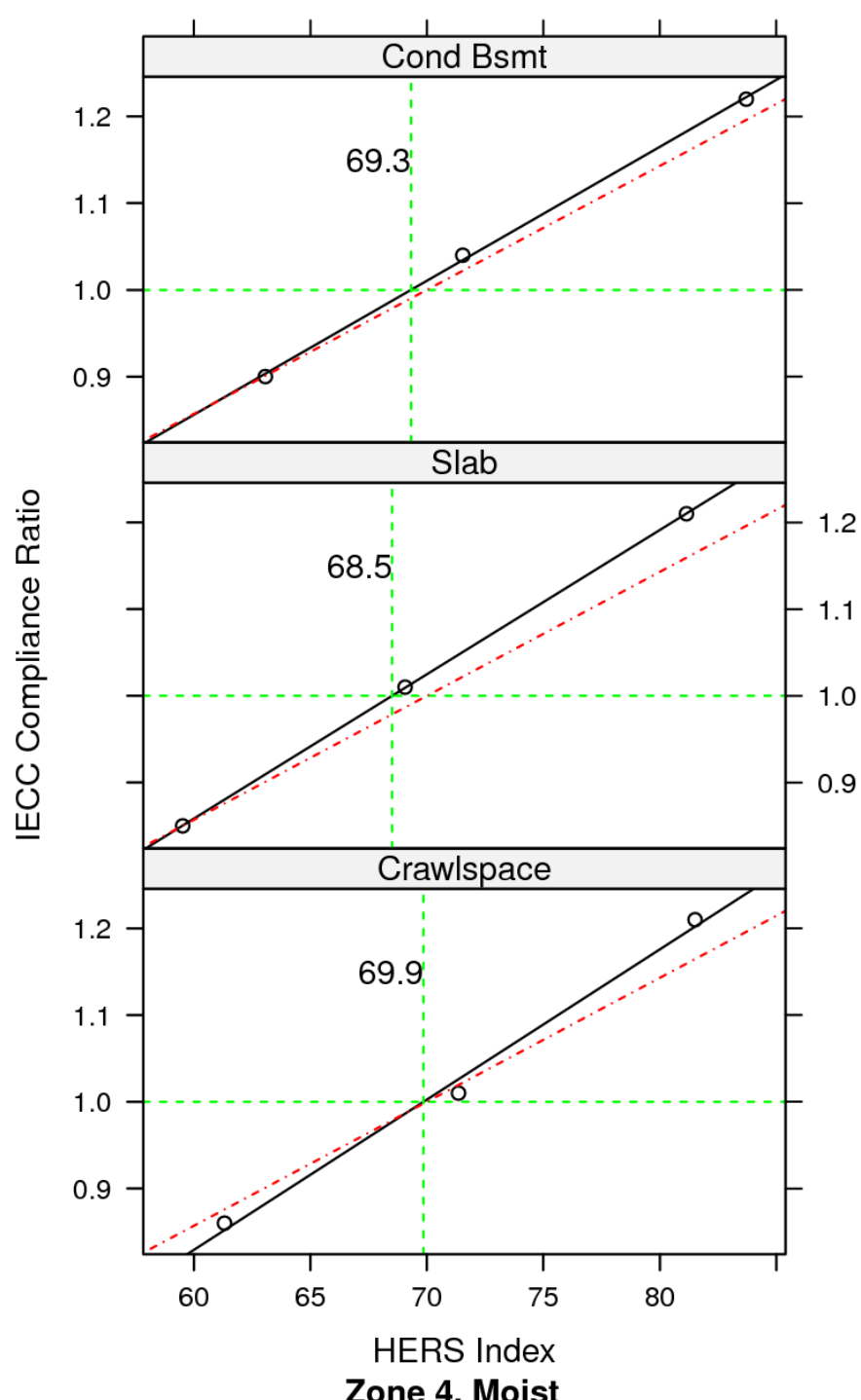

Appliances

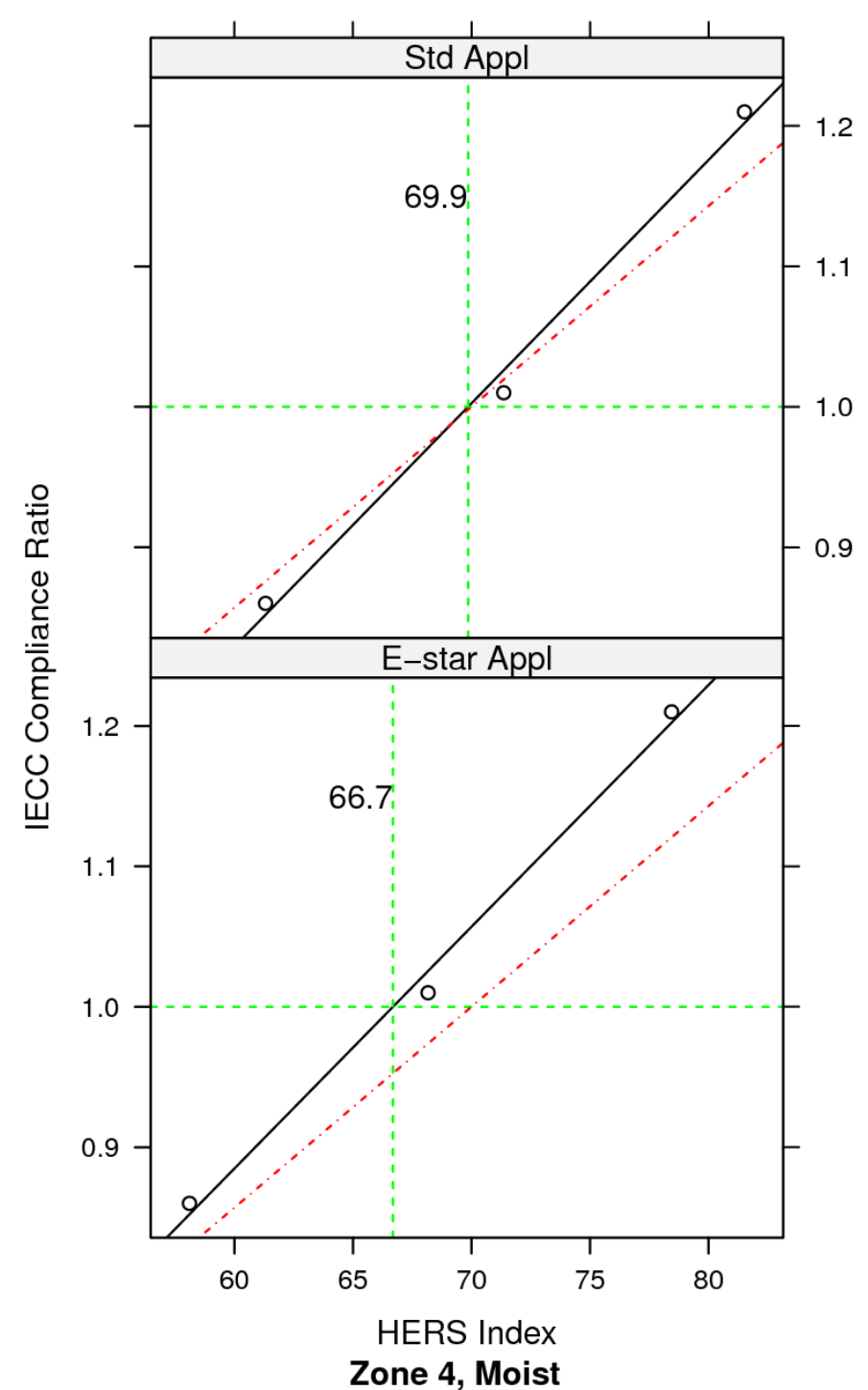

Figure A.7. Corresponding HERS Indexes for Climate Zone 4, Moist Regime (contd) 


\section{Glazing Orientation}

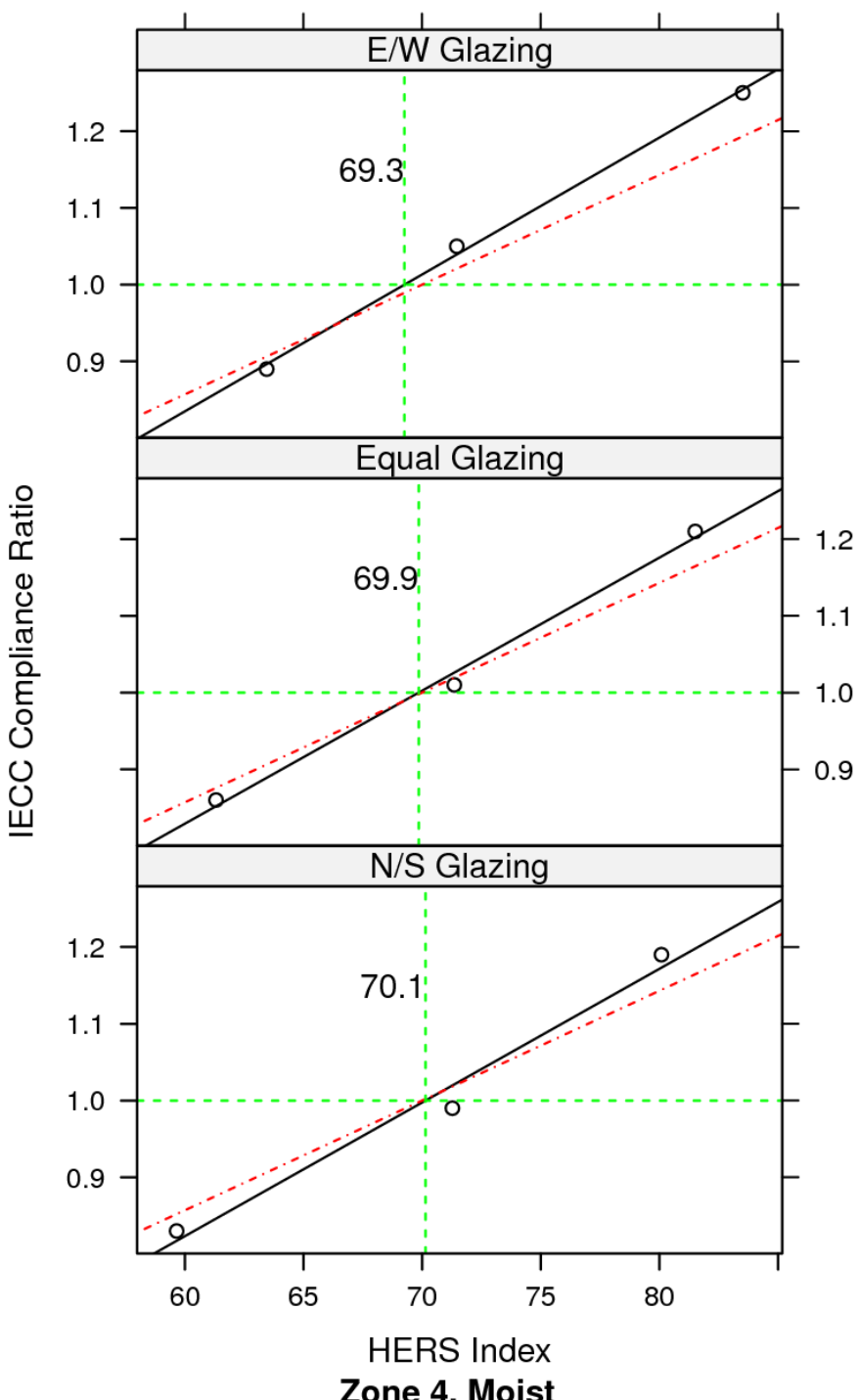

Number of Stories

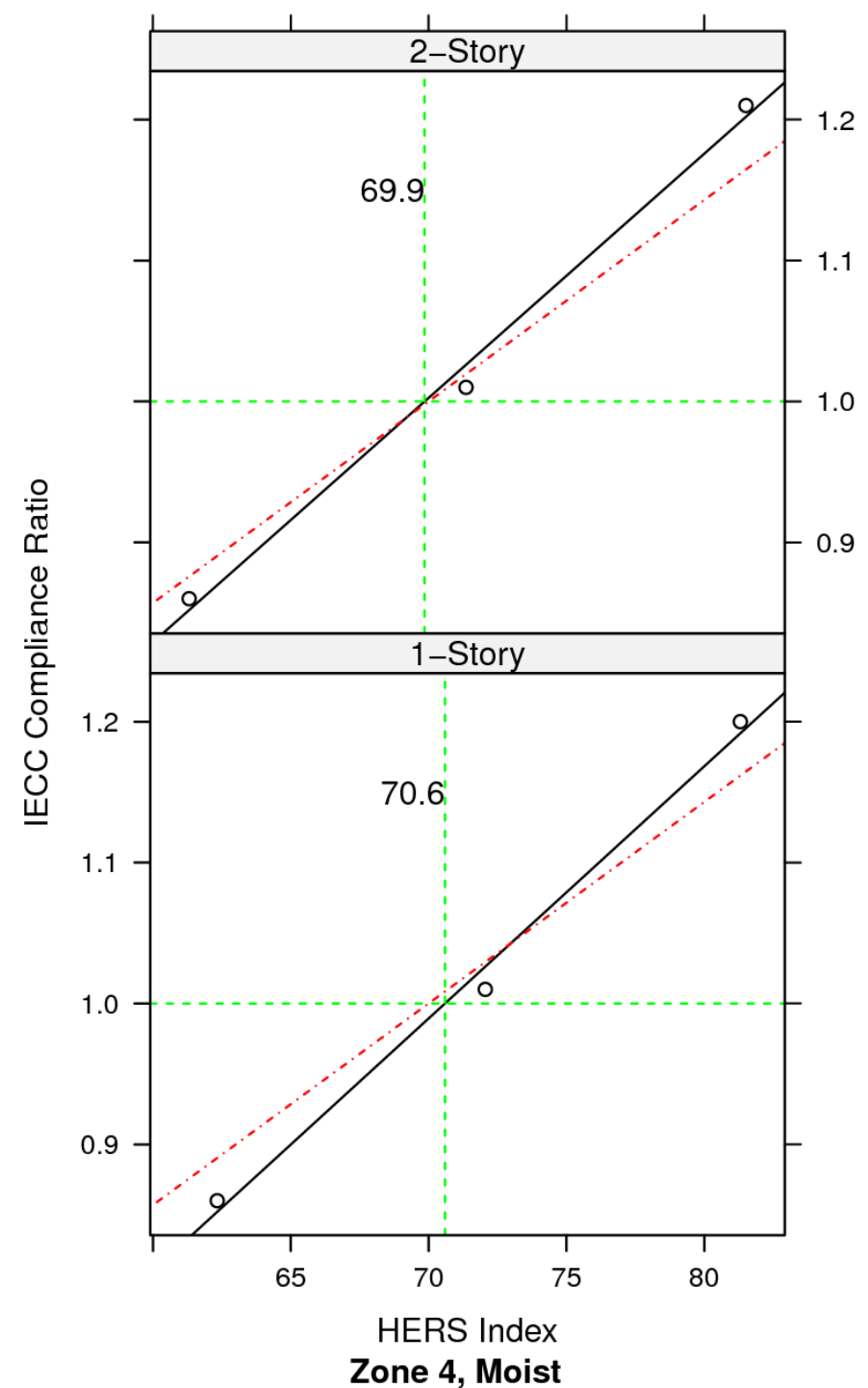

Figure A.7. Corresponding HERS Indexes for Climate Zone 4, Moist Regime (contd) 
Heat Pump Efficiency

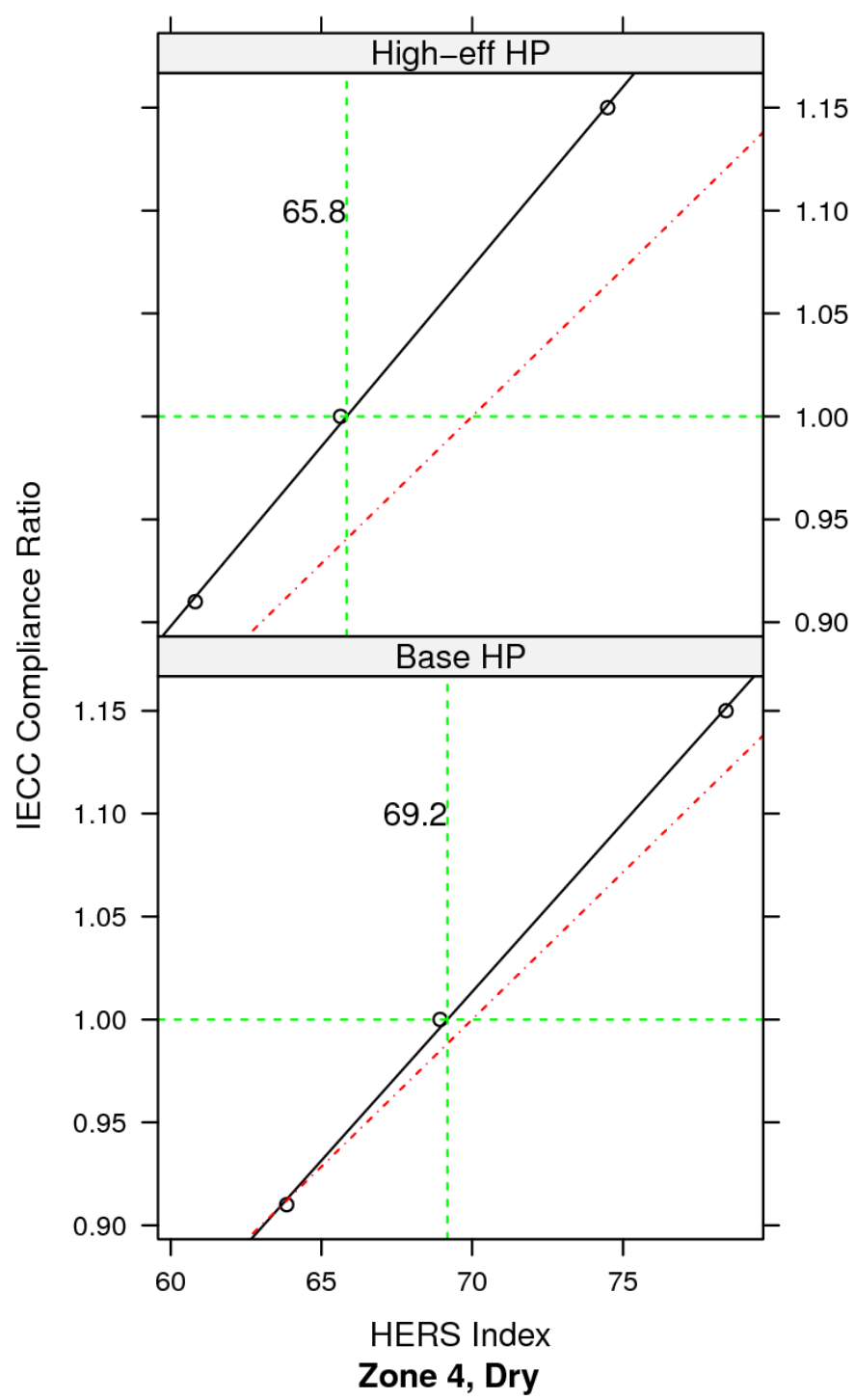

Gas Furnace \& AC Efficiency

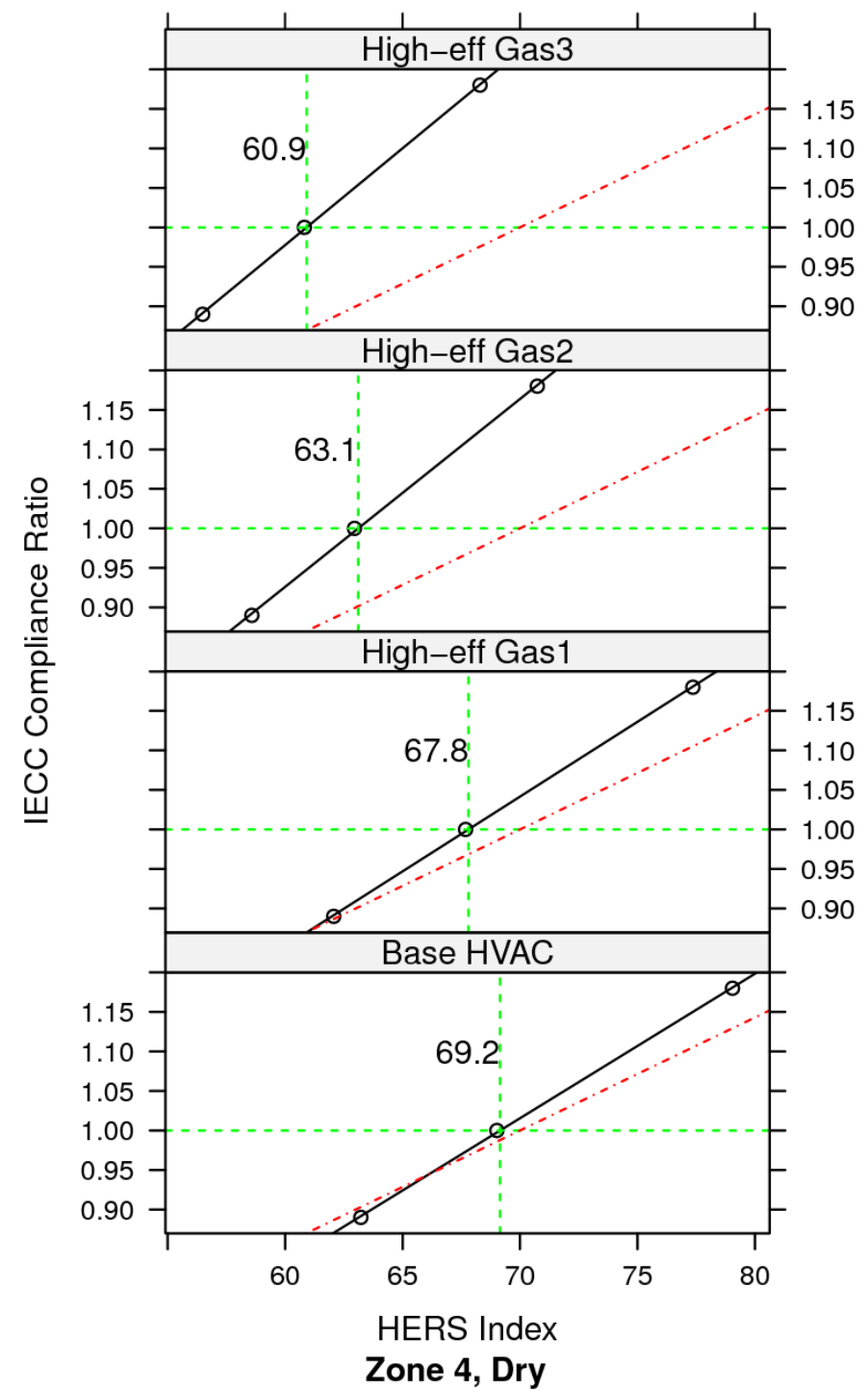

Figure A.8. Corresponding HERS Indexes for Climate Zone 4, Dry Regime 
Window-Floor Ratio

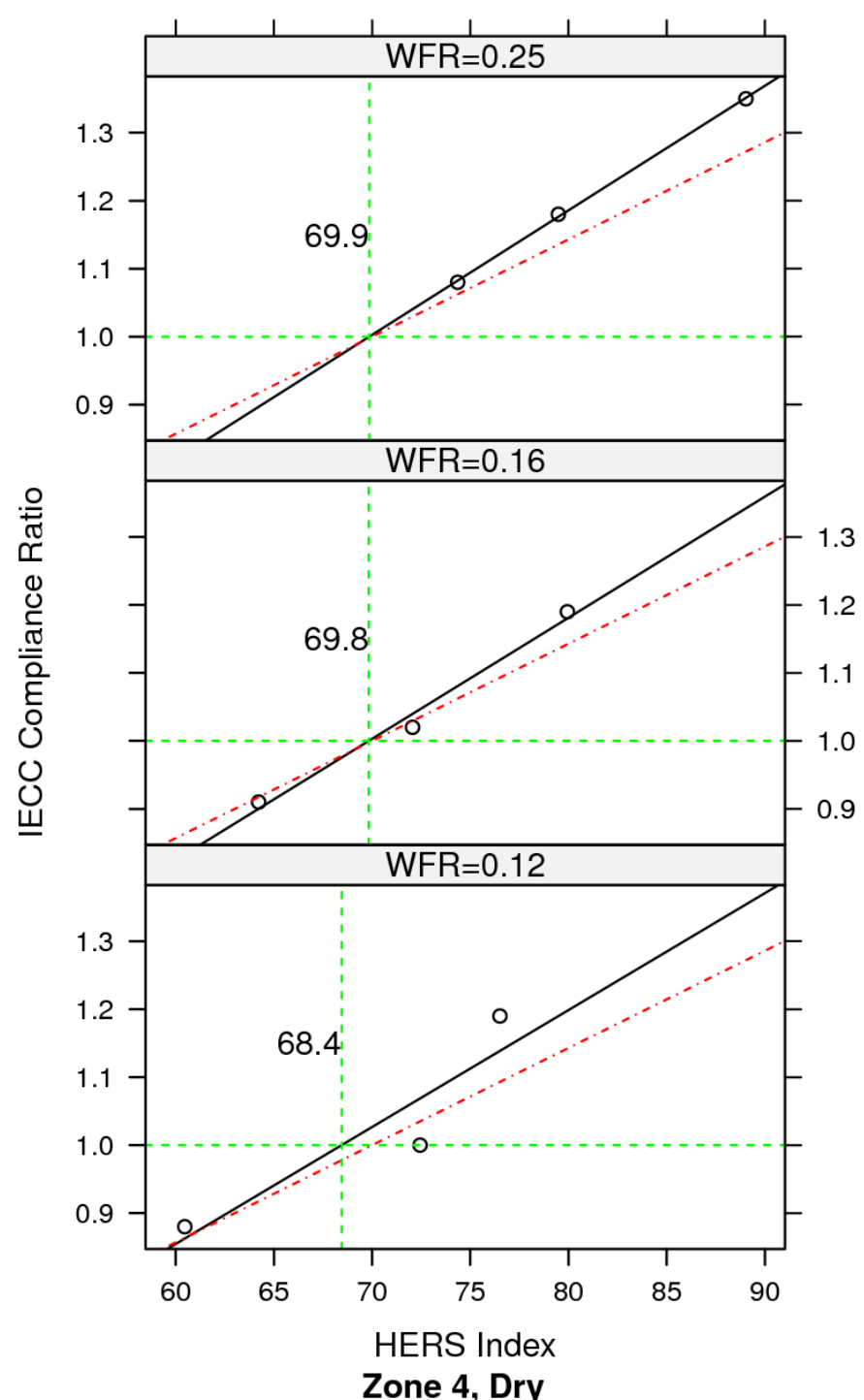

\section{Conditioned Floor Area}

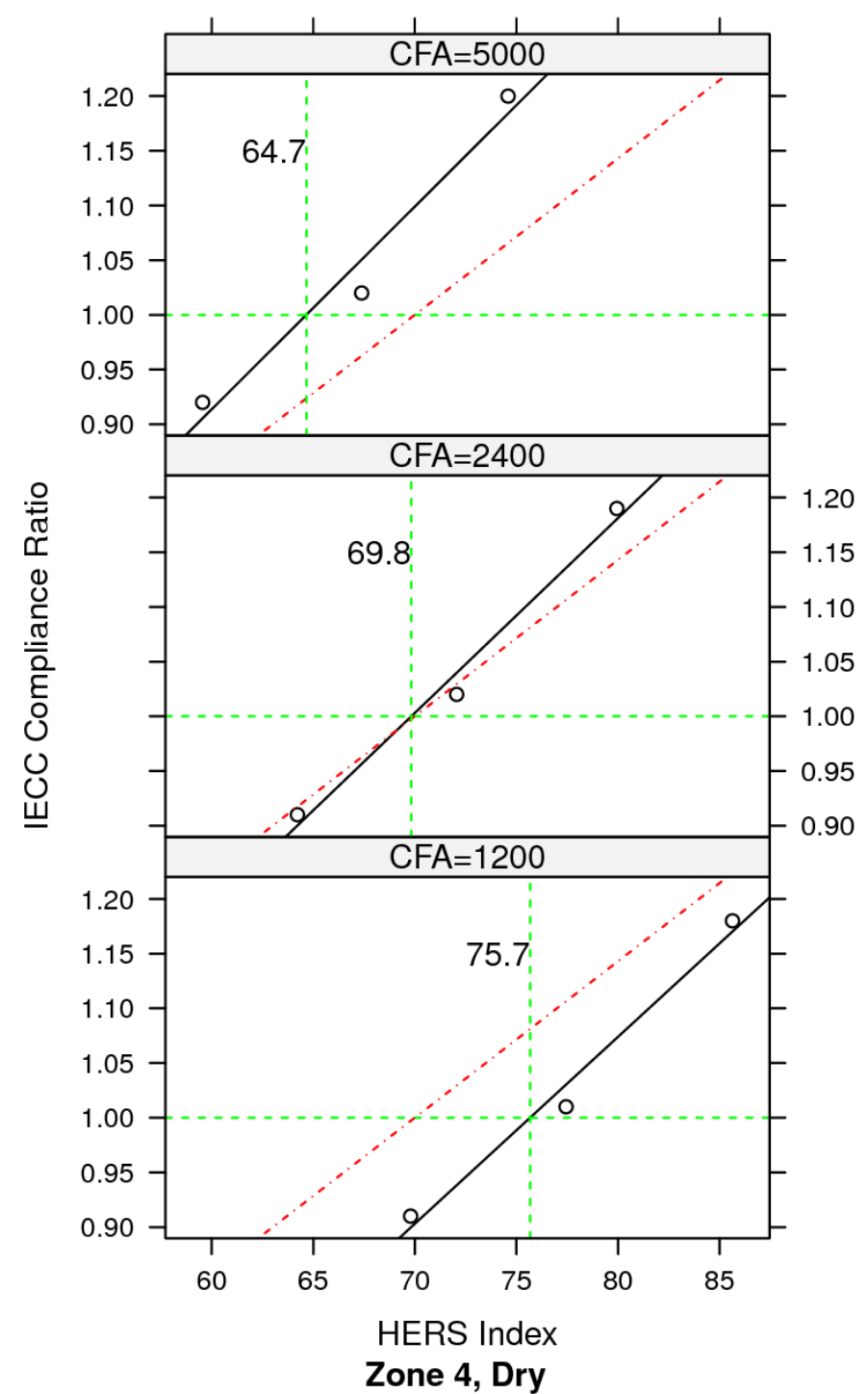

Figure A.8. Corresponding HERS Indexes for Climate Zone 4, Dry Regime (contd) 
Foundation

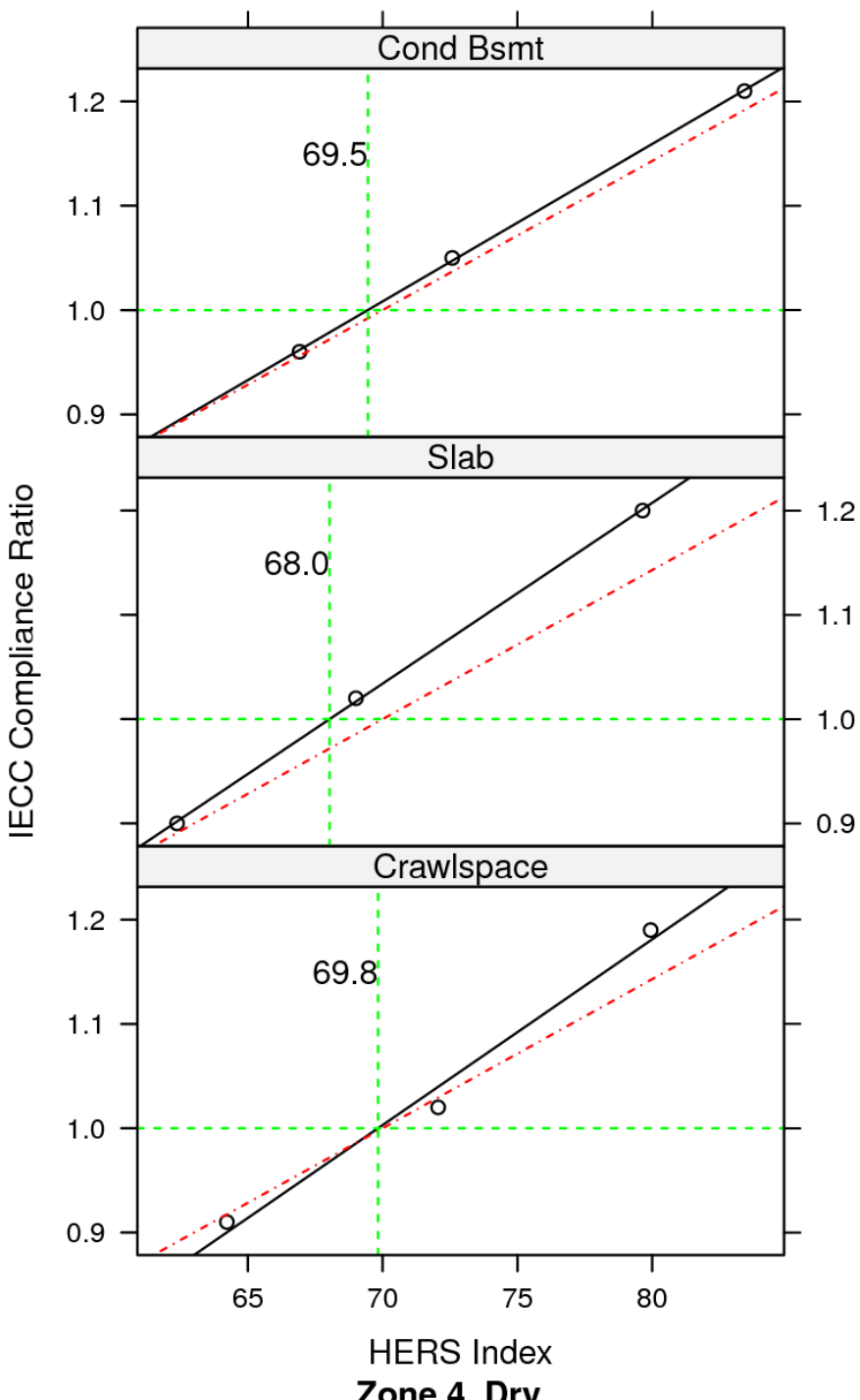

Appliances

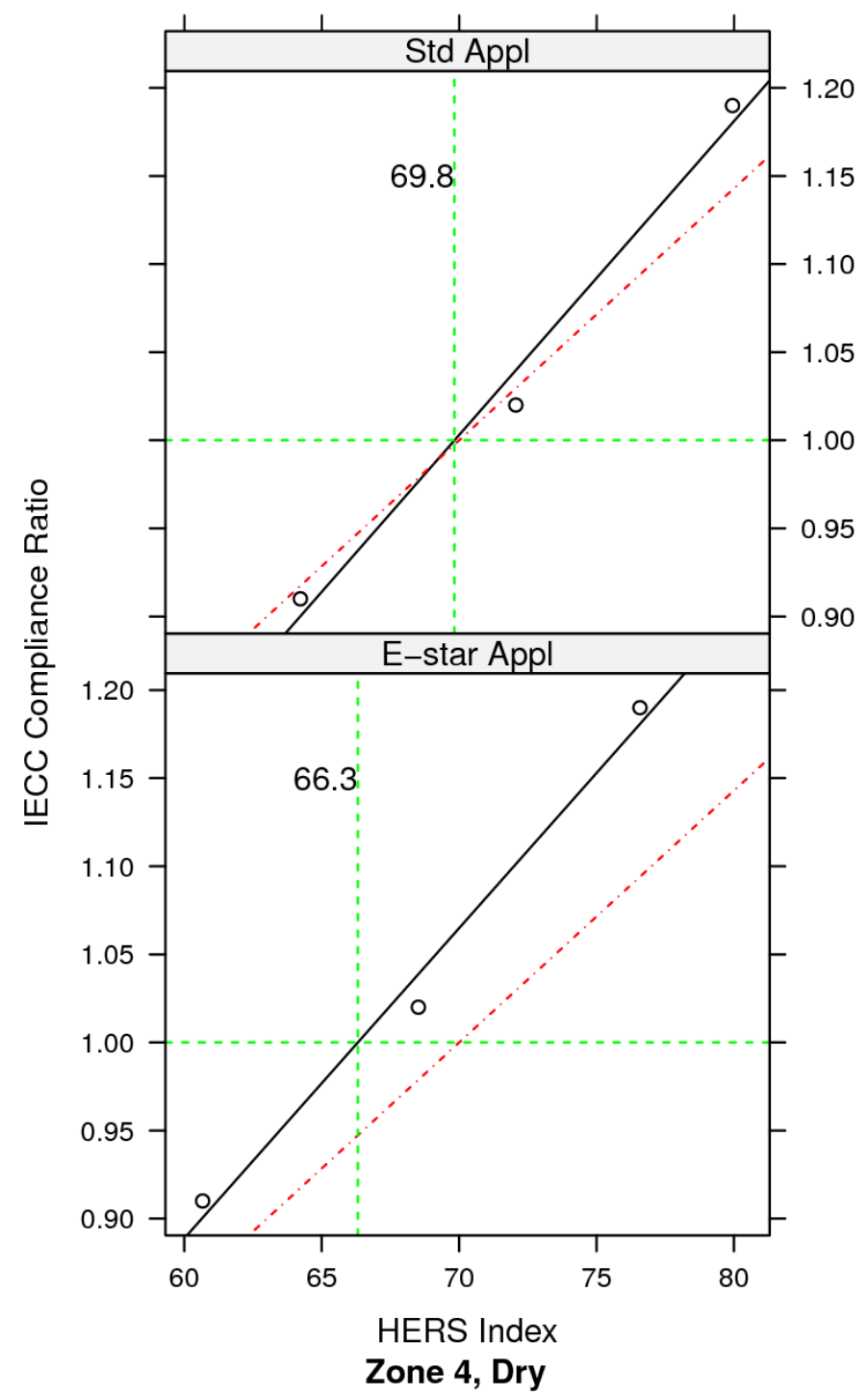

Figure A.8. Corresponding HERS Indexes for Climate Zone 4, Dry Regime (contd) 


\section{Glazing Orientation}

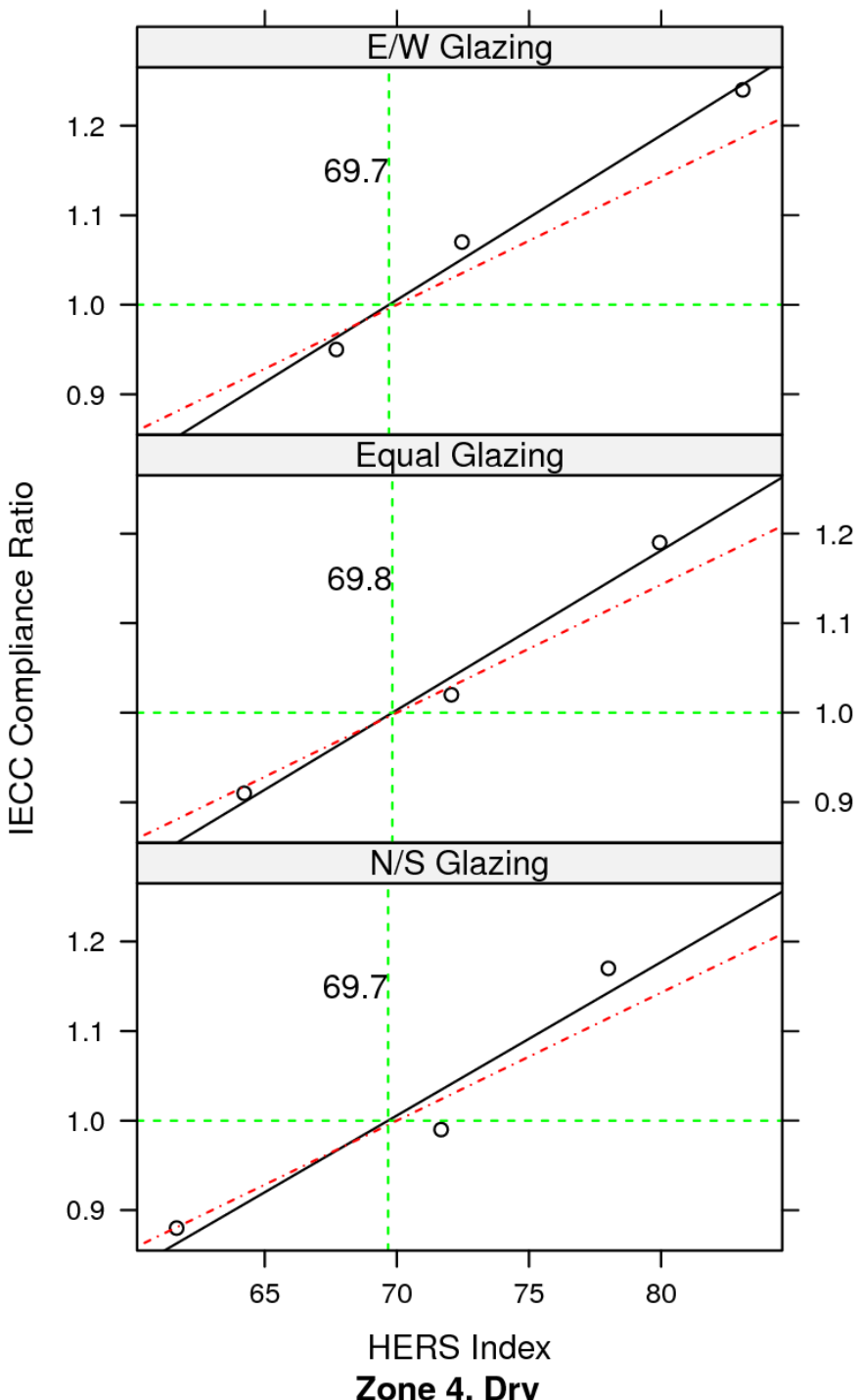

Number of Stories

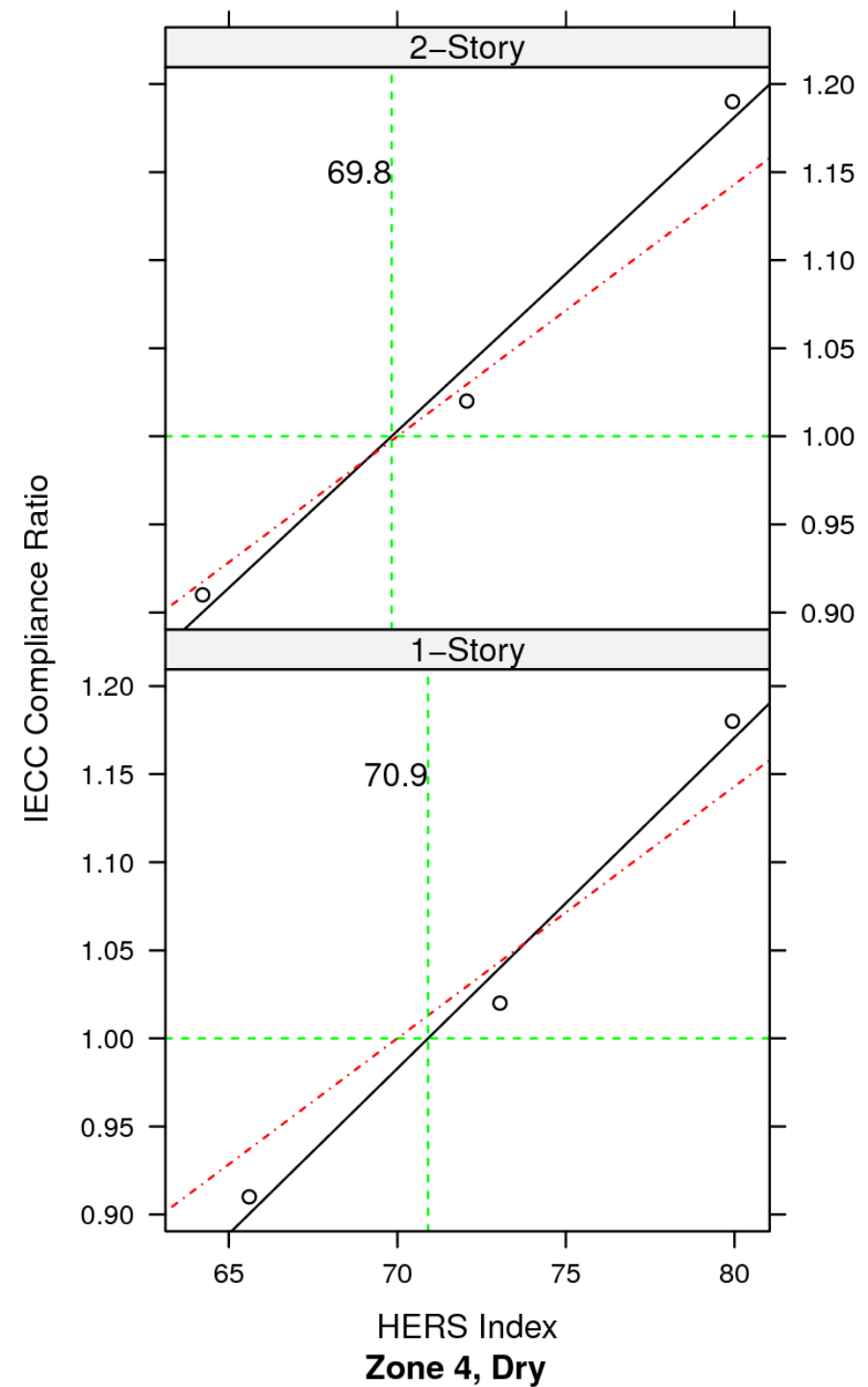

Figure A.8. Corresponding HERS Indexes for Climate Zone 4, Dry Regime (contd) 
Heat Pump Efficiency

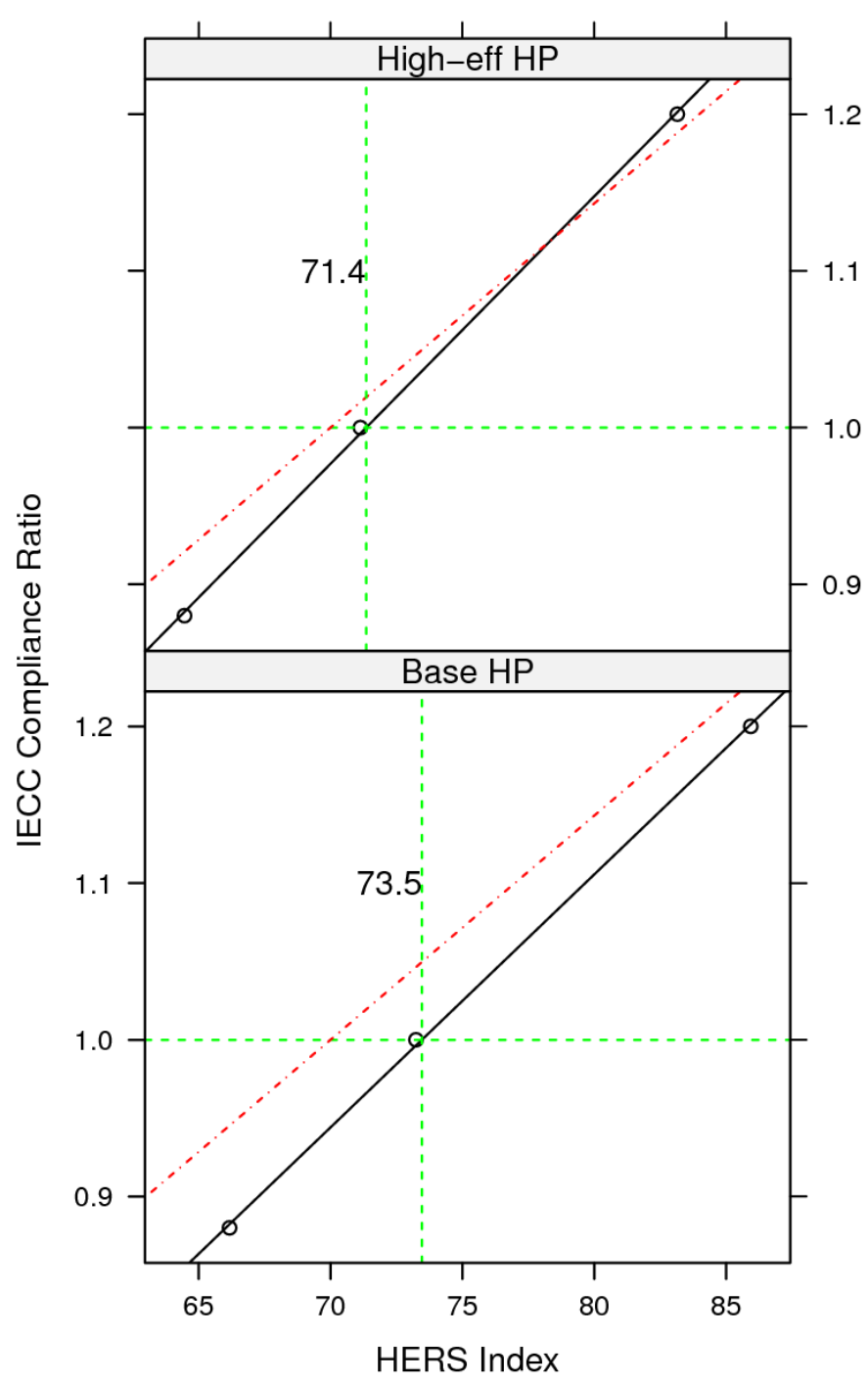

Zone 4, Marine
Gas Furnace \& AC Efficiency

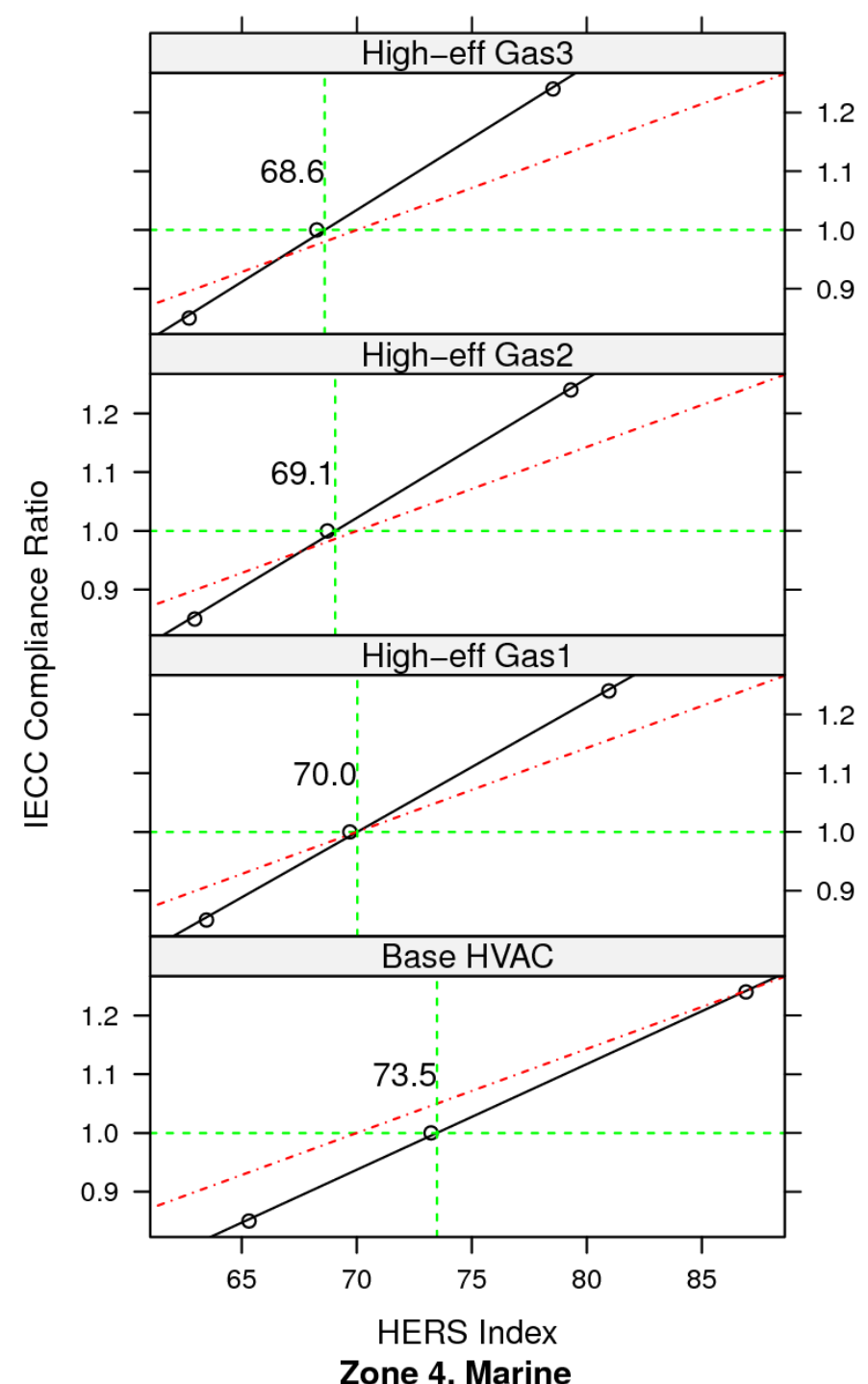

Figure A.9. Corresponding HERS Indexes for Climate Zone 4, Marine Regime 
Window-Floor Ratio

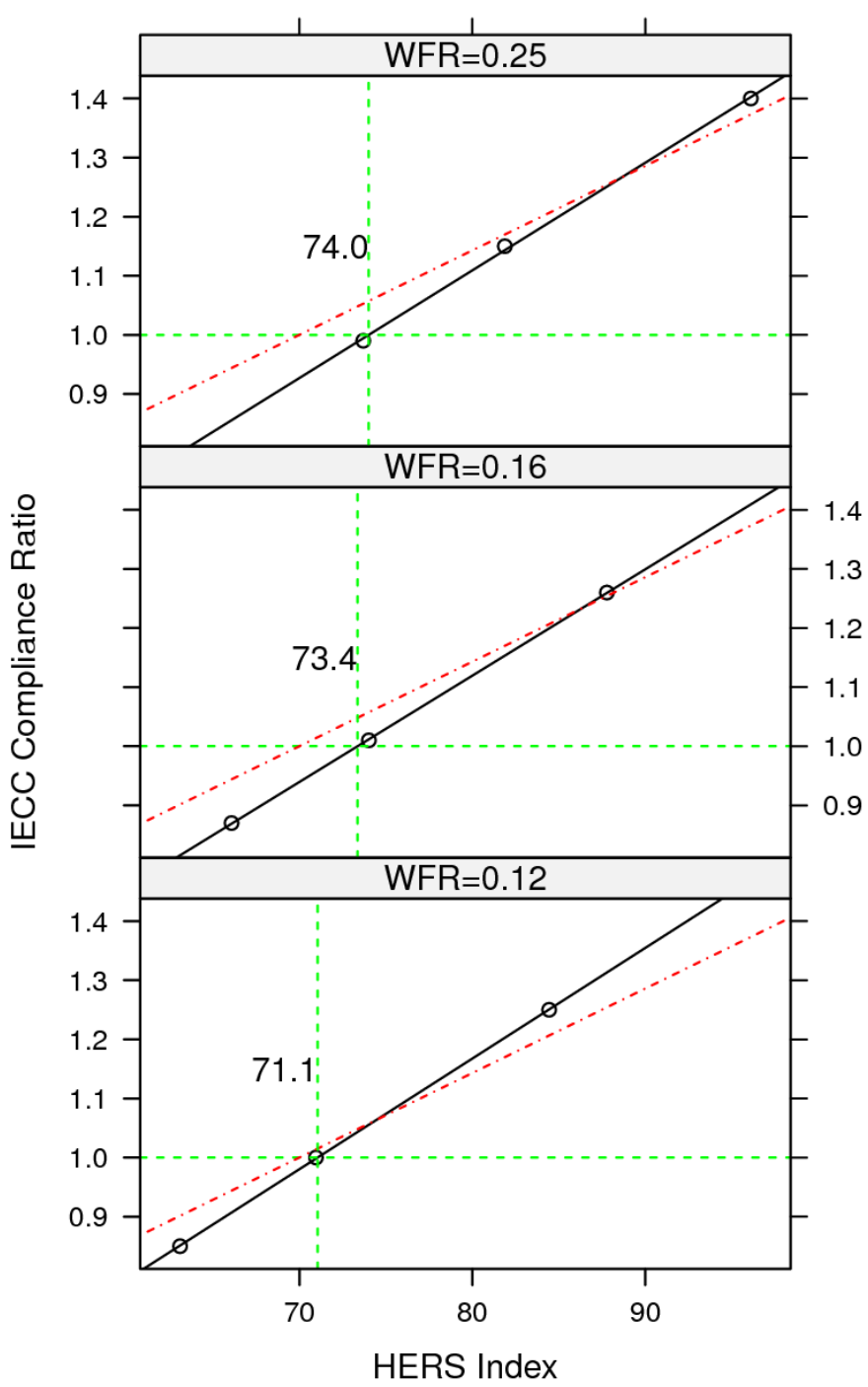

Zone 4, Marine

\section{Conditioned Floor Area}

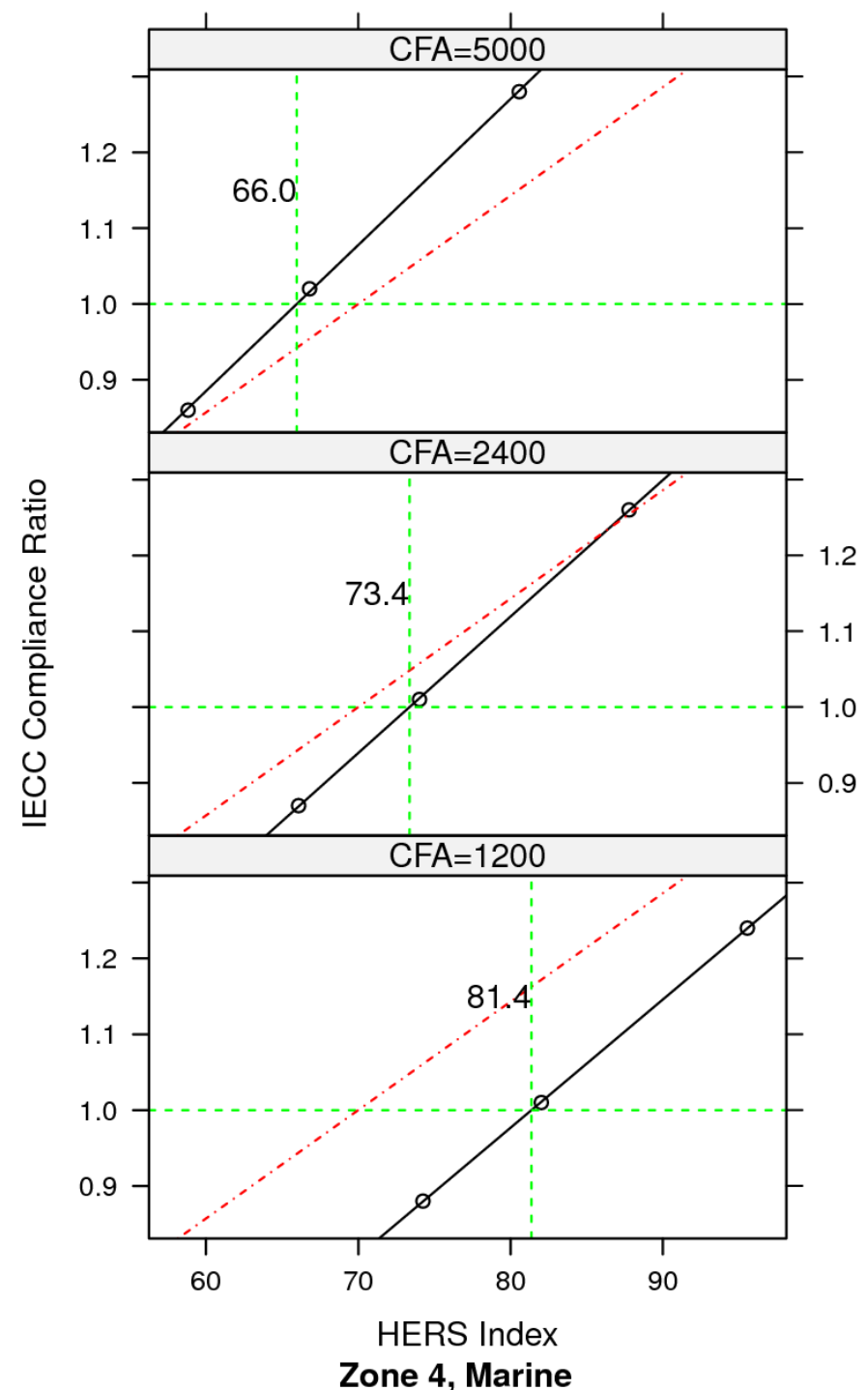

Figure A.9. Corresponding HERS Indexes for Climate Zone 4, Marine Regime (contd) 
Foundation

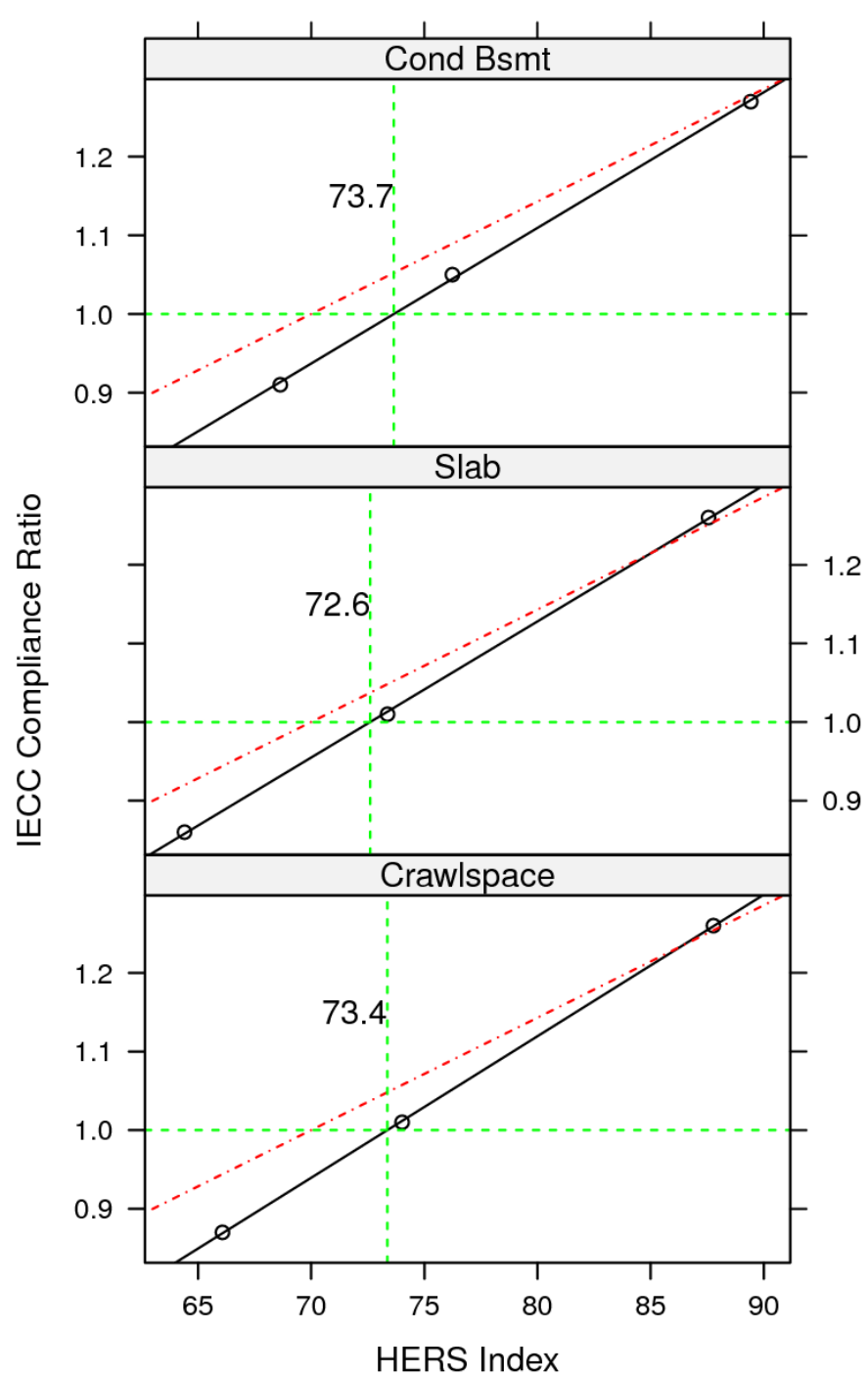

Zone 4, Marine

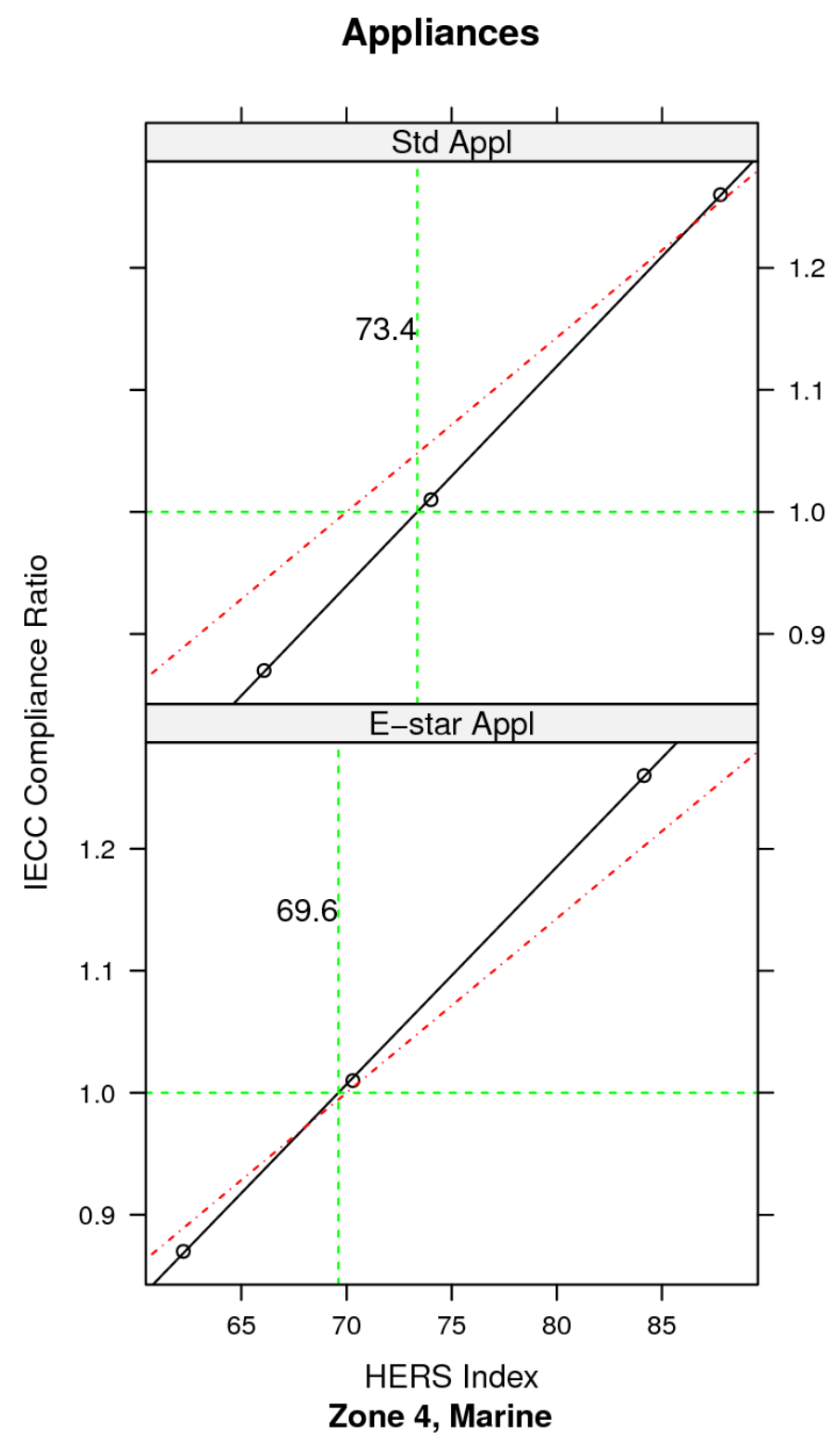

Zone 4, Marine

Figure A.9. Corresponding HERS Indexes for Climate Zone 4, Marine Regime (contd) 


\section{Glazing Orientation}

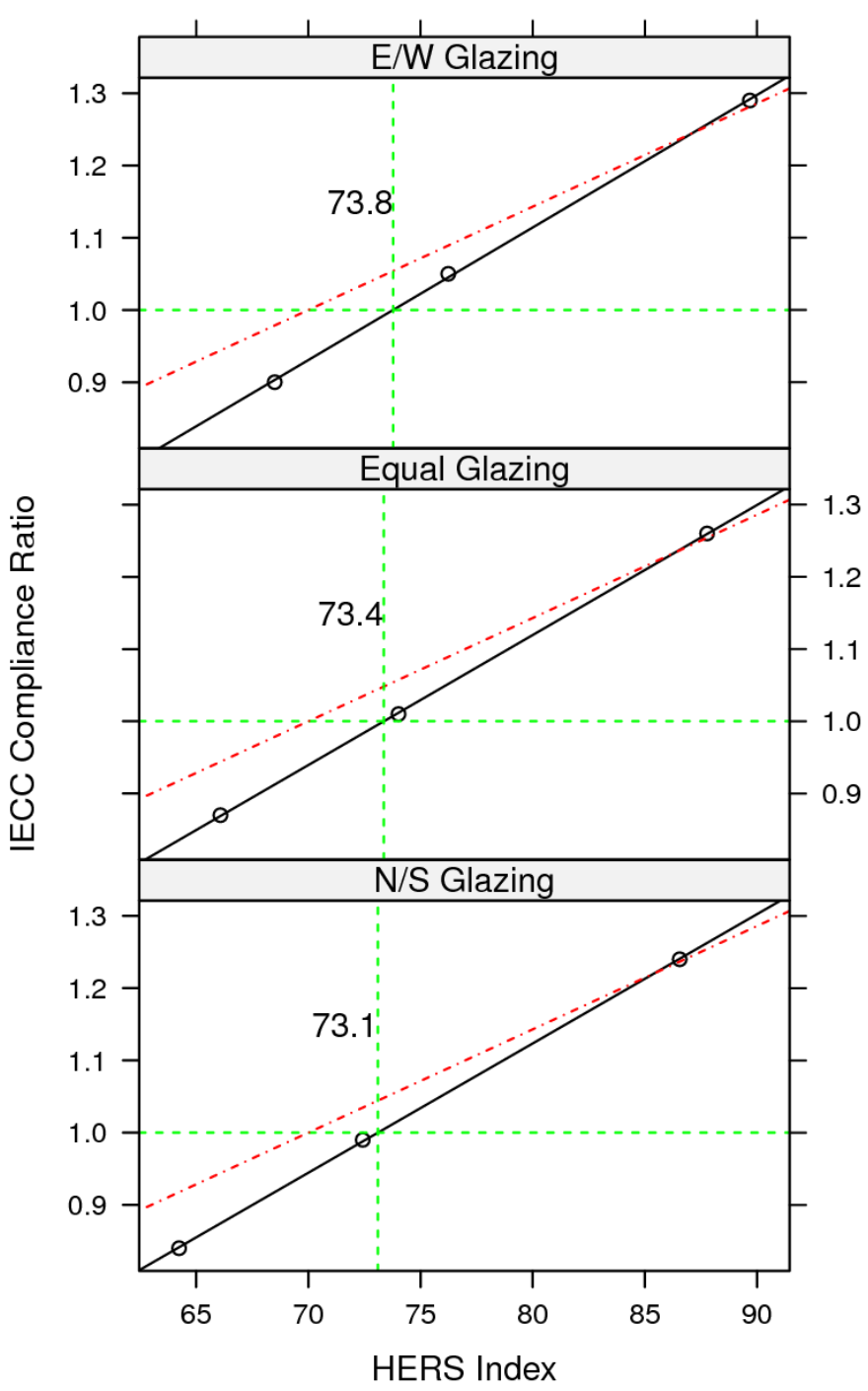

Zone 4, Marine
Number of Stories

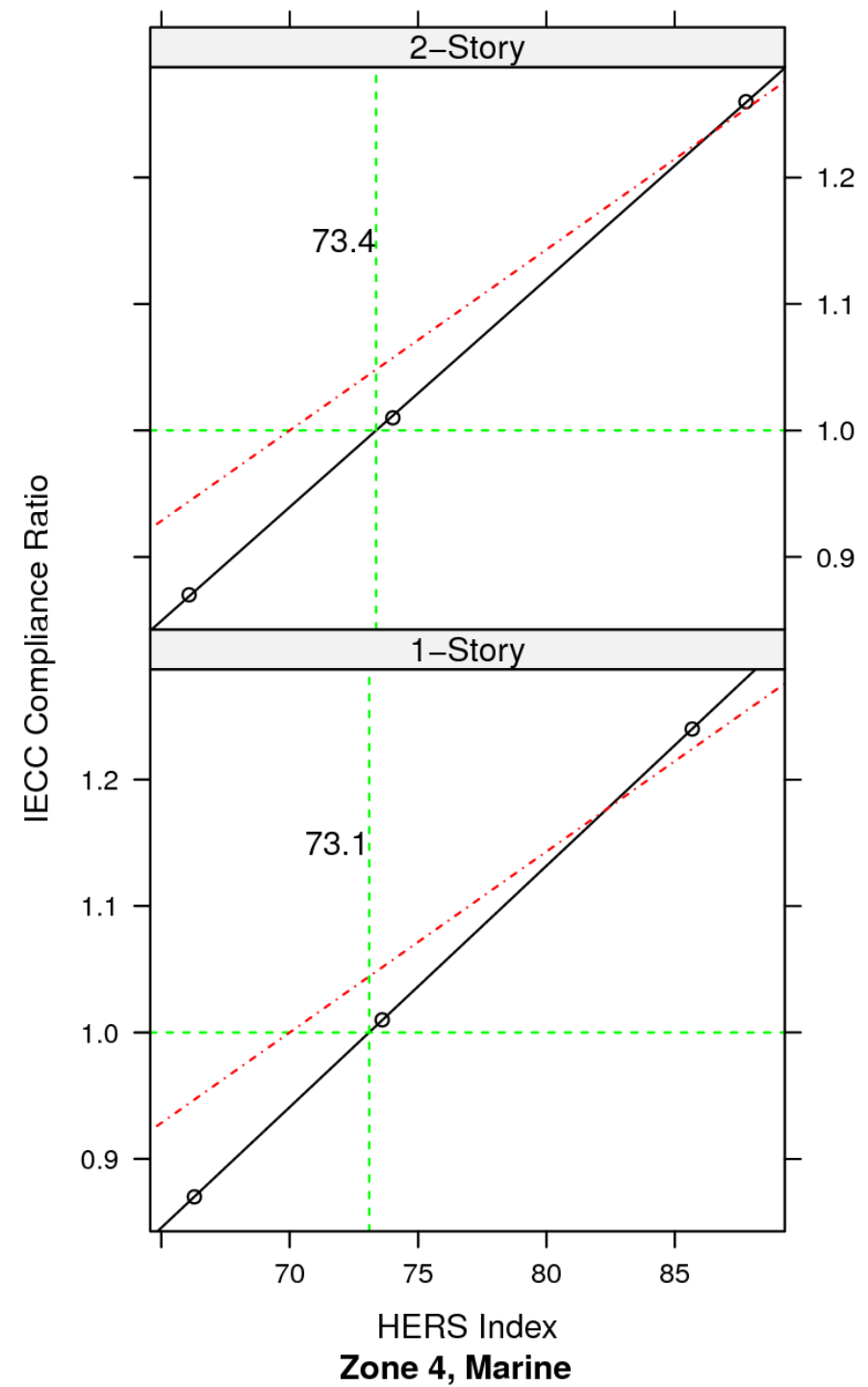

Figure A.9. Corresponding HERS Indexes for Climate Zone 4, Marine Regime (contd) 
Heat Pump Efficiency

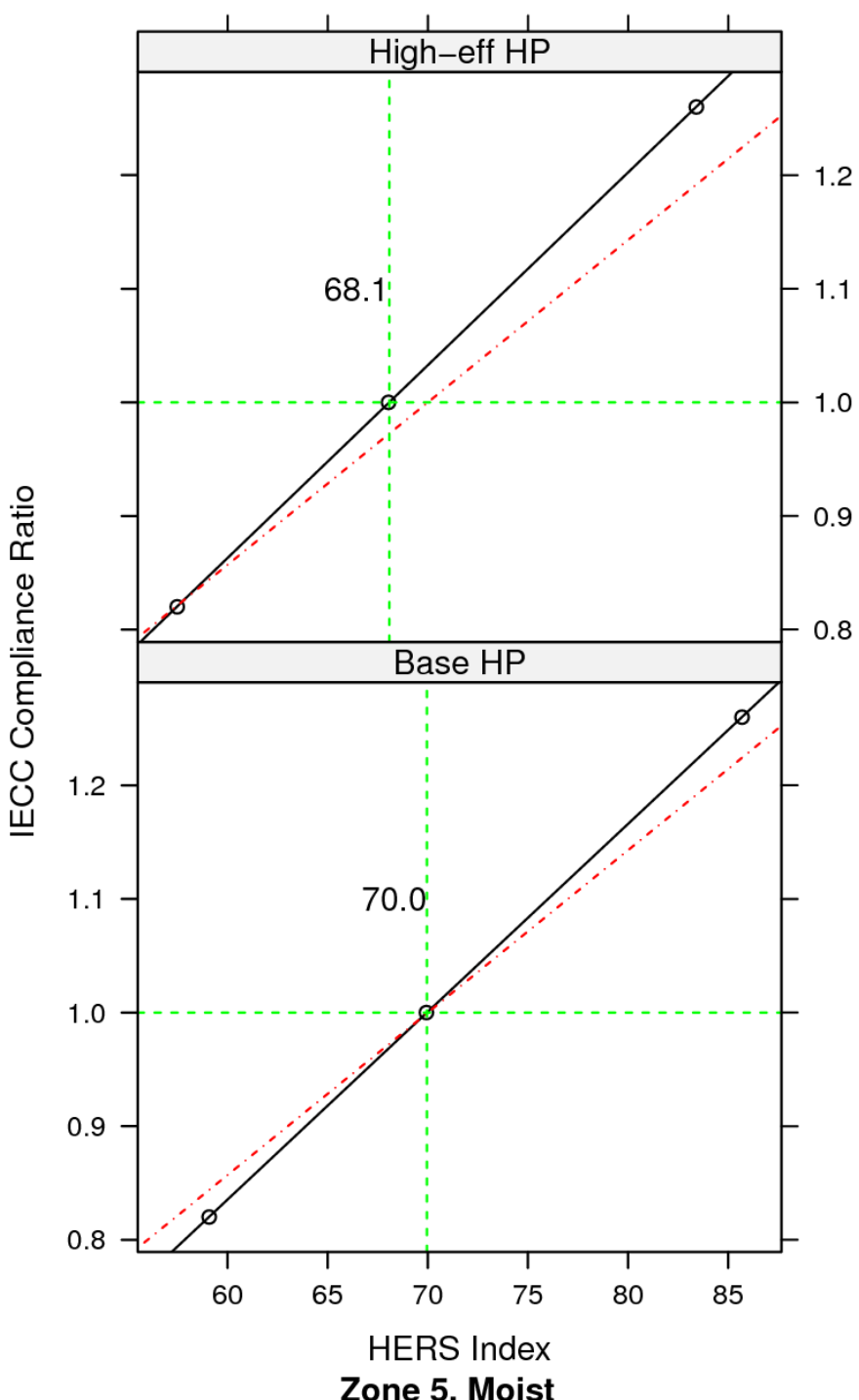

Gas Furnace \& AC Efficiency

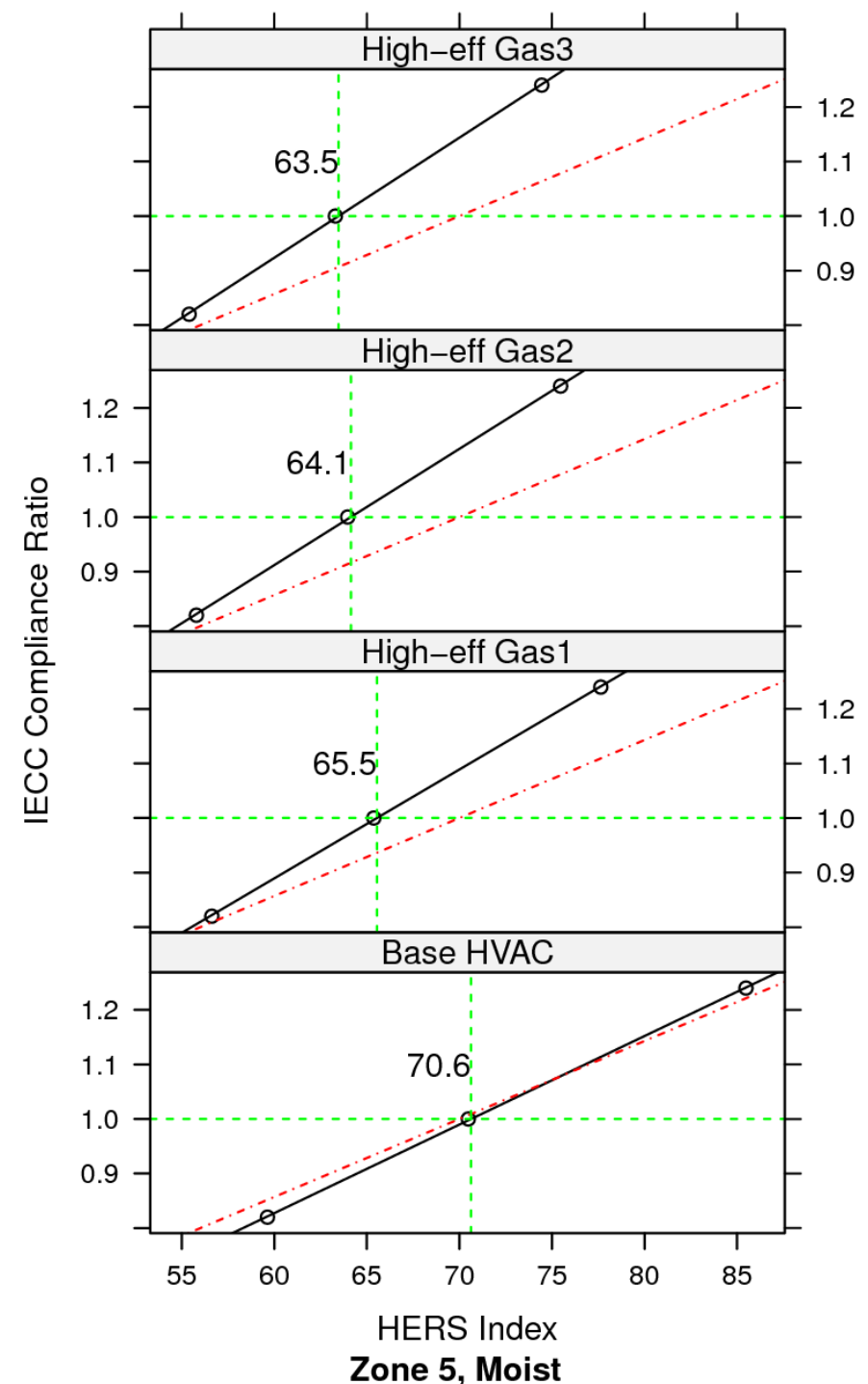

Figure A.10. Corresponding HERS Indexes for Climate Zone 5, Moist Regime 
Window-Floor Ratio

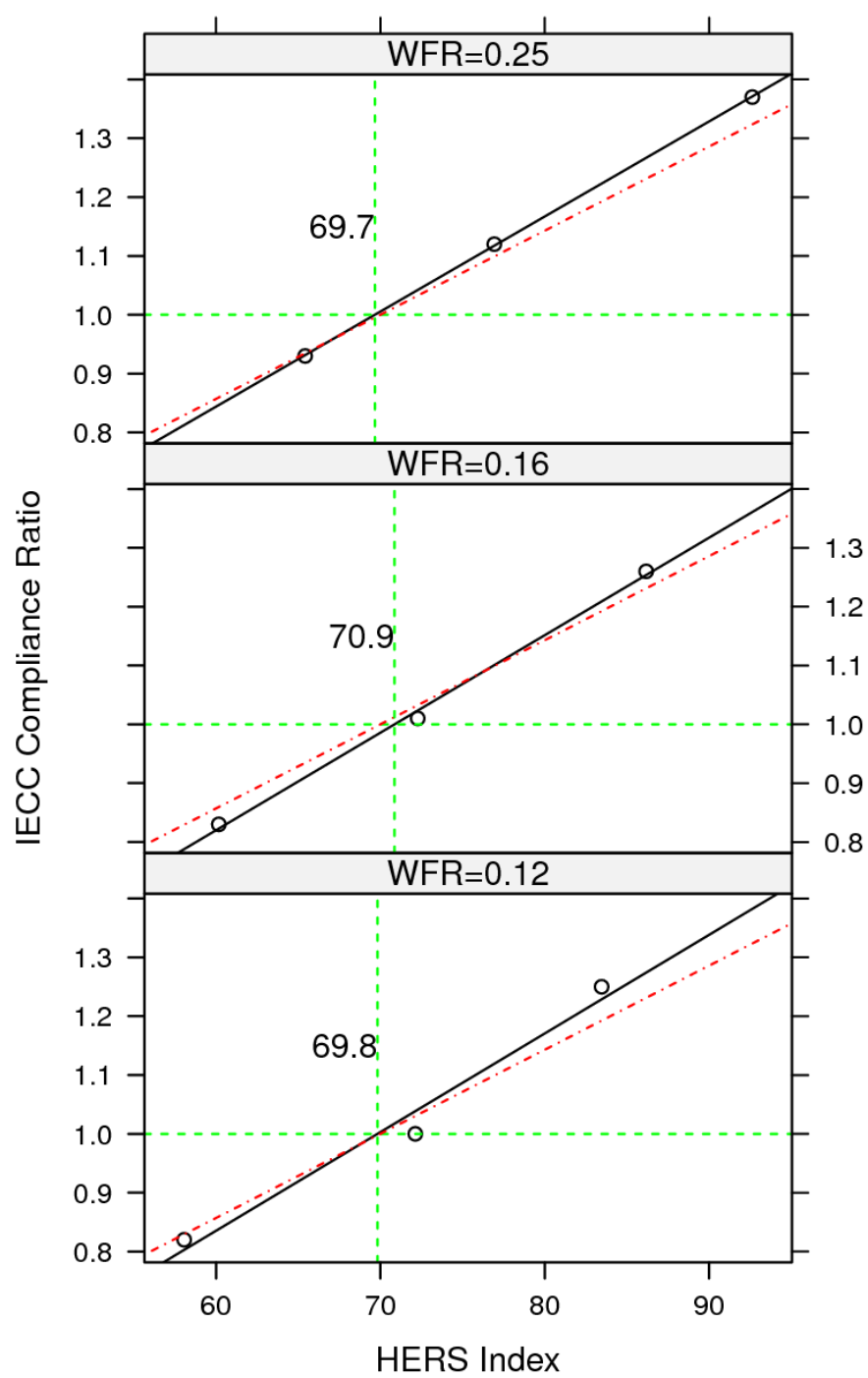

ERS Index

Zone 5, Moist

\section{Conditioned Floor Area}

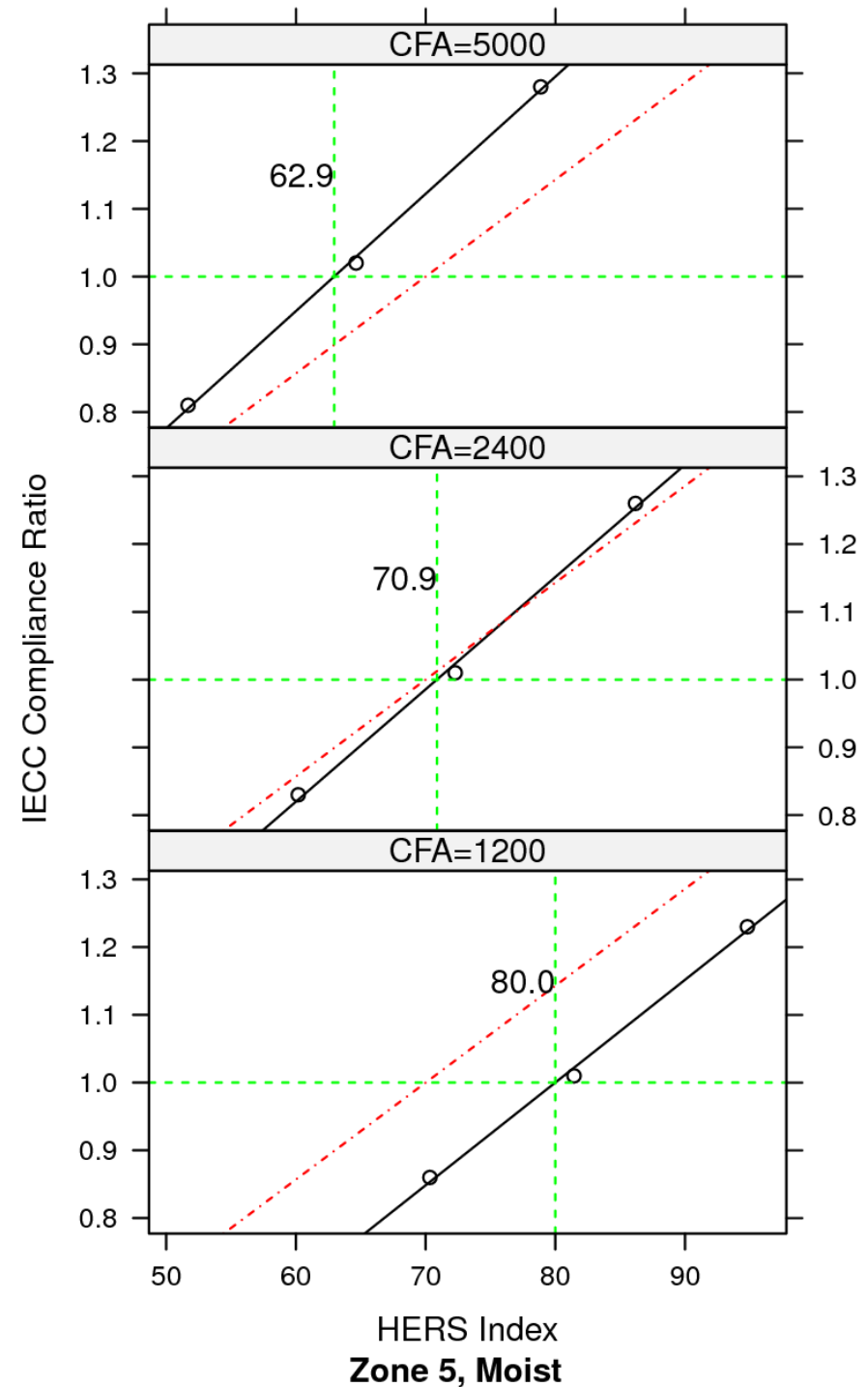

Figure A.10. Corresponding HERS Indexes for Climate Zone 5, Moist Regime (contd) 
Foundation

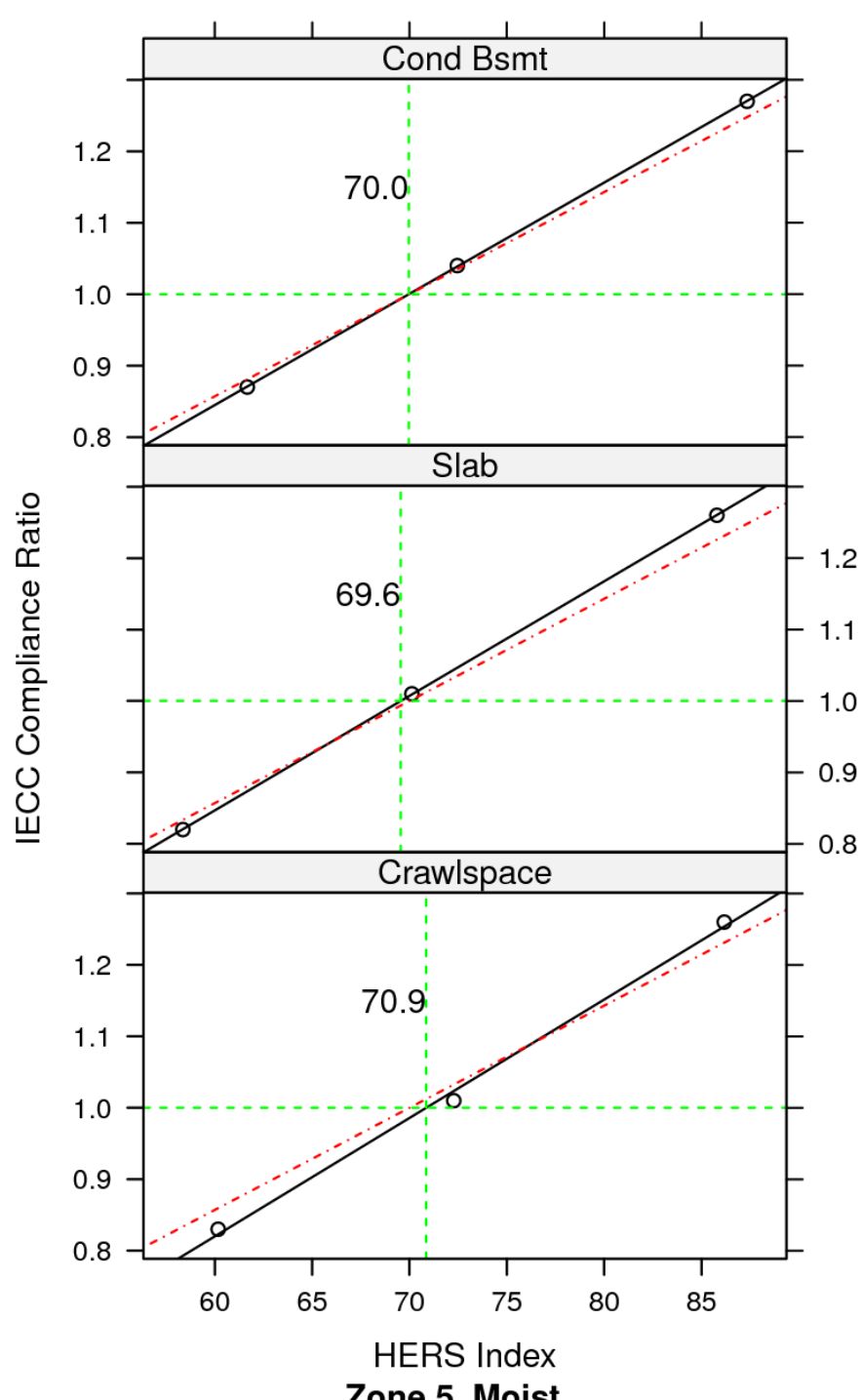

Appliances

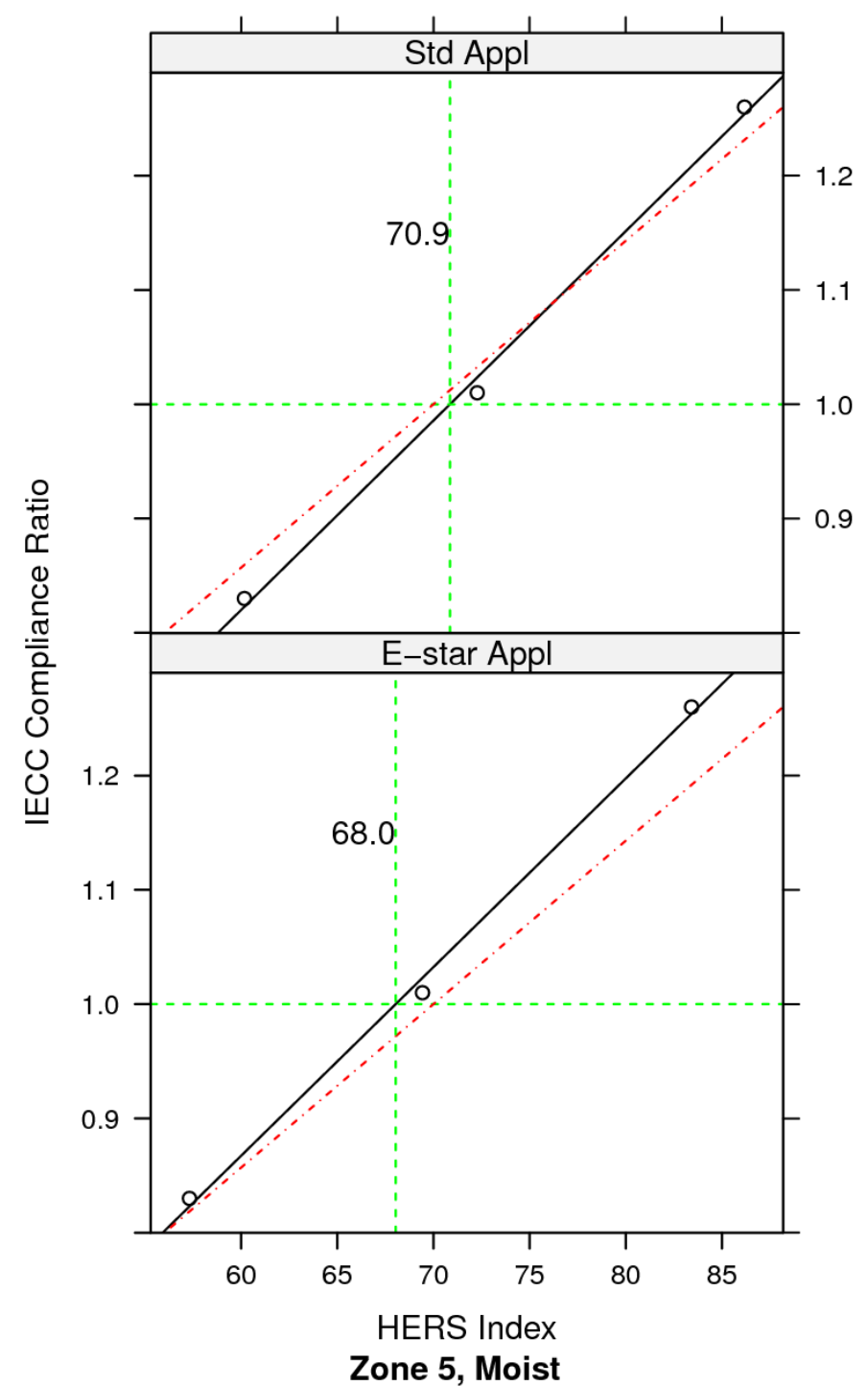

Figure A.10. Corresponding HERS Indexes for Climate Zone 5, Moist Regime (contd) 


\section{Glazing Orientation}

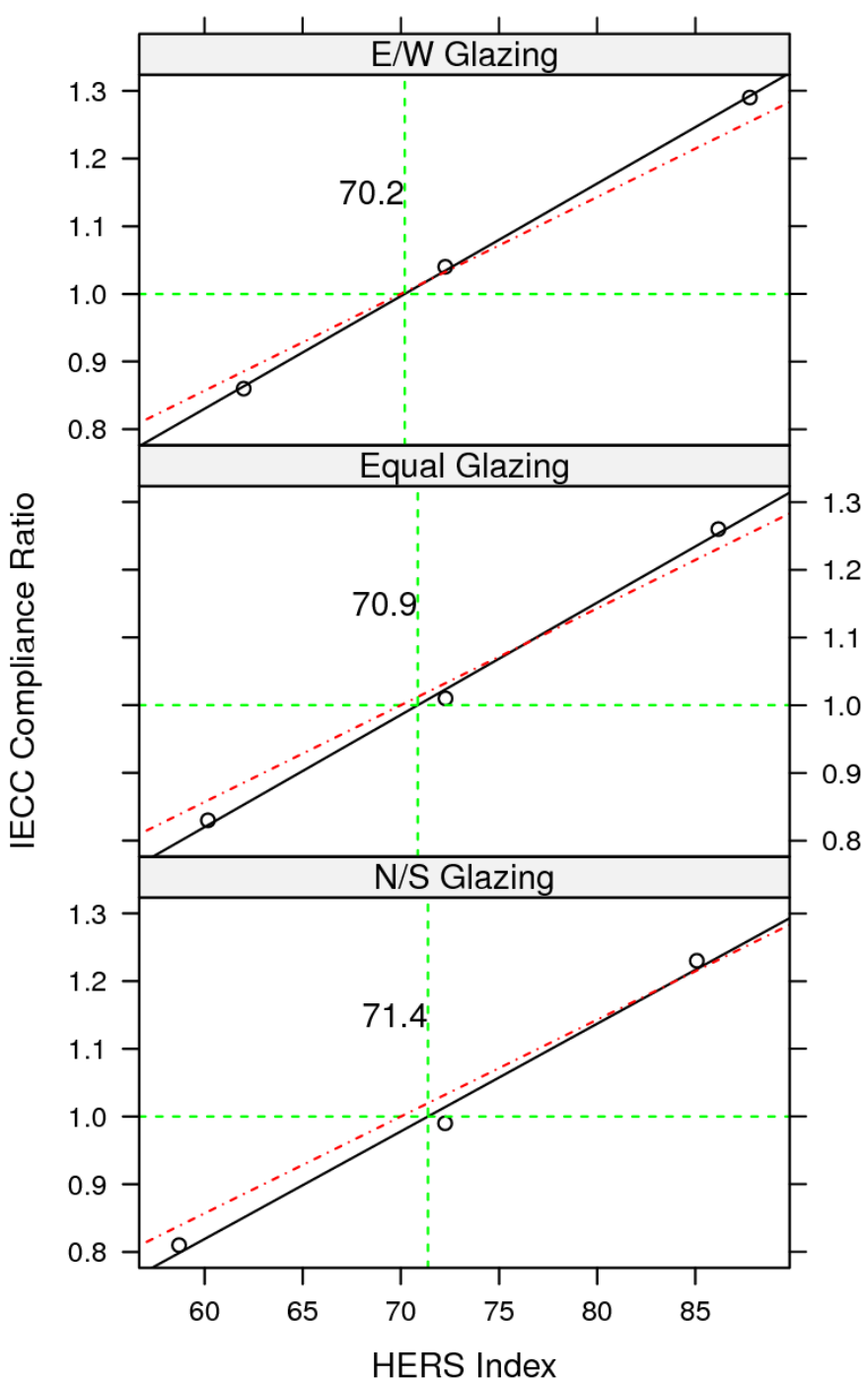

Zone 5, Moist
Number of Stories

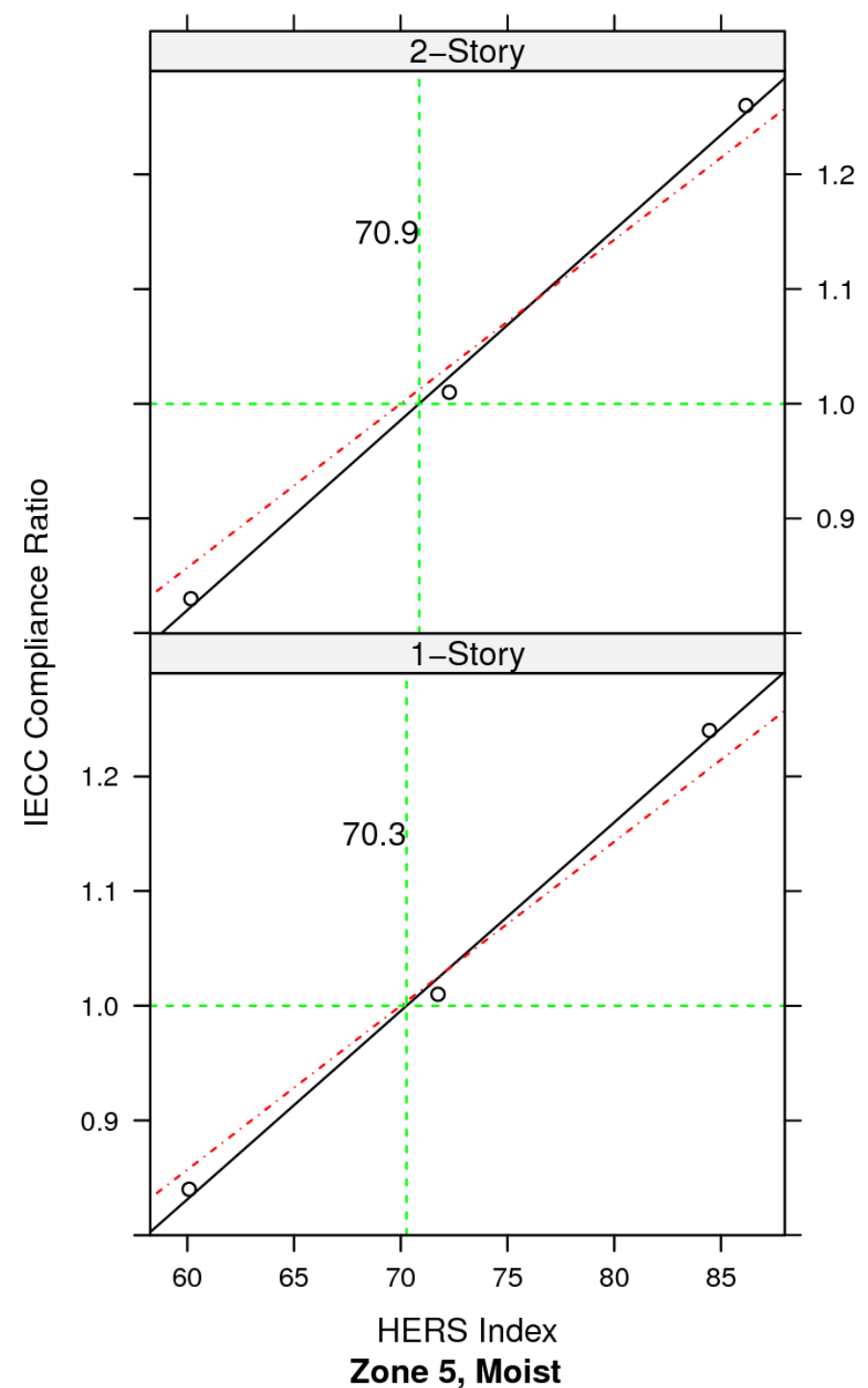

Figure A.10. Corresponding HERS Indexes for Climate Zone 5, Moist Regime (contd) 
Heat Pump Efficiency

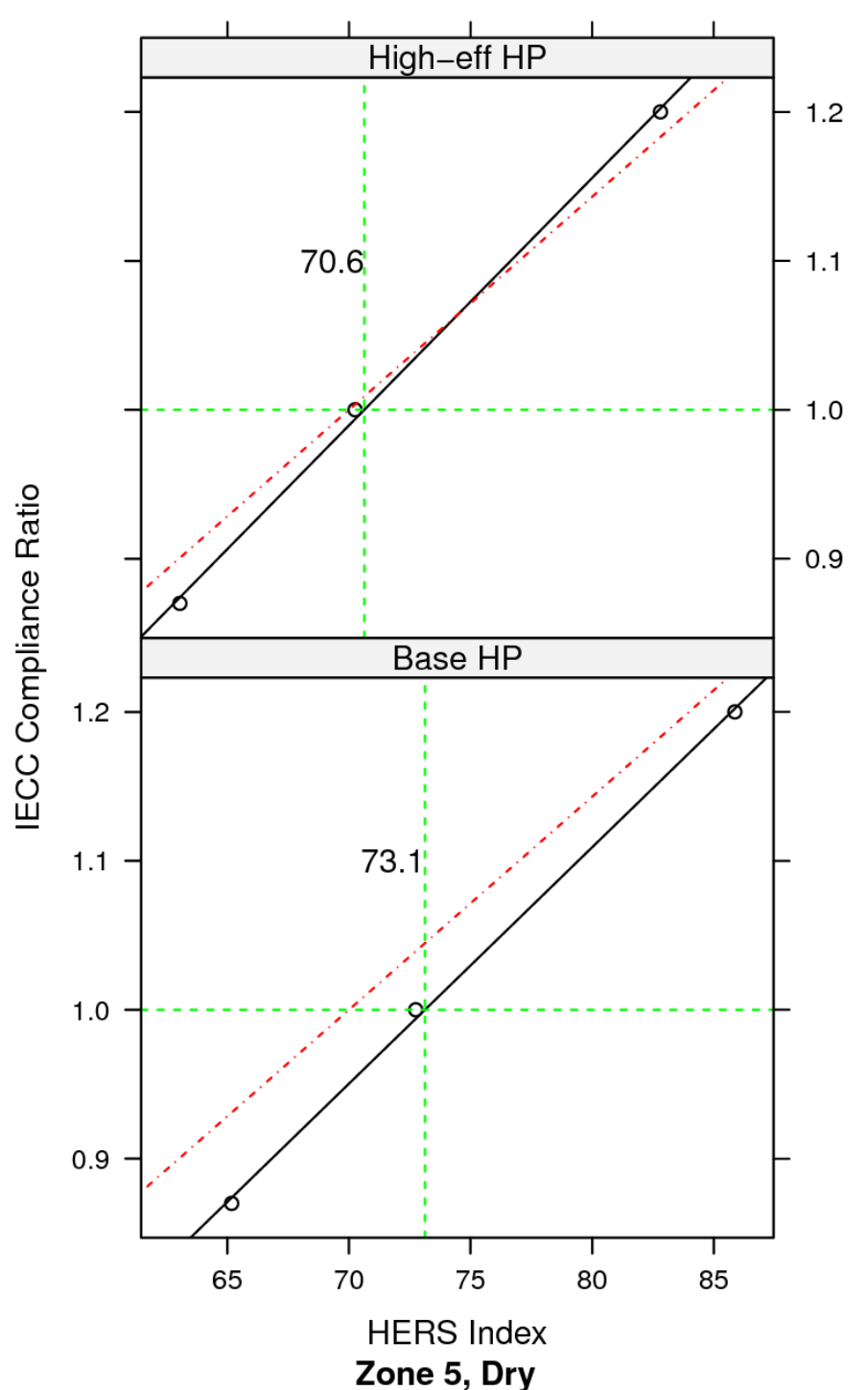

Gas Furnace \& AC Efficiency

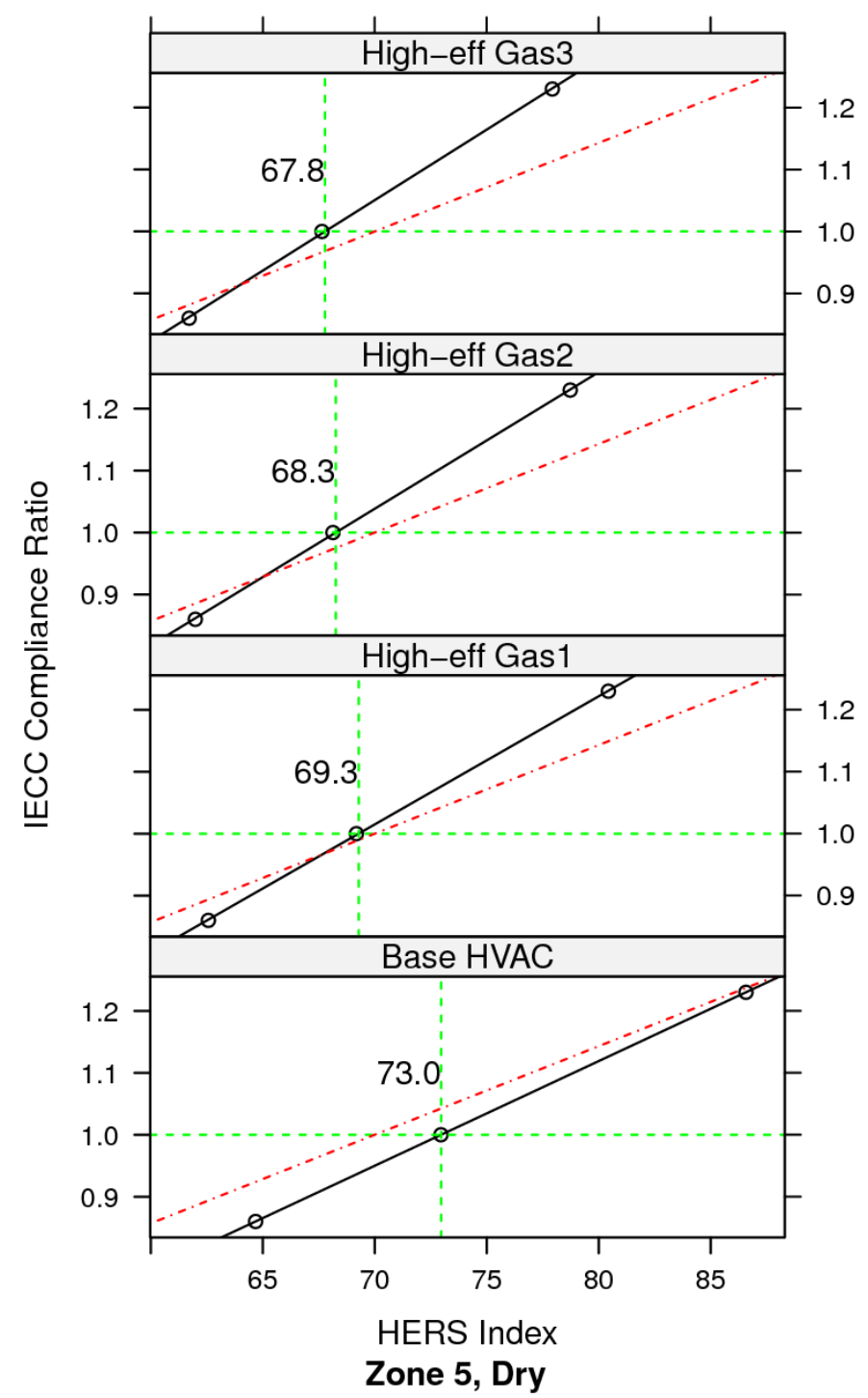

Figure A.11. Corresponding HERS Indexes for Climate Zone 5, Dry Regime 
Window-Floor Ratio

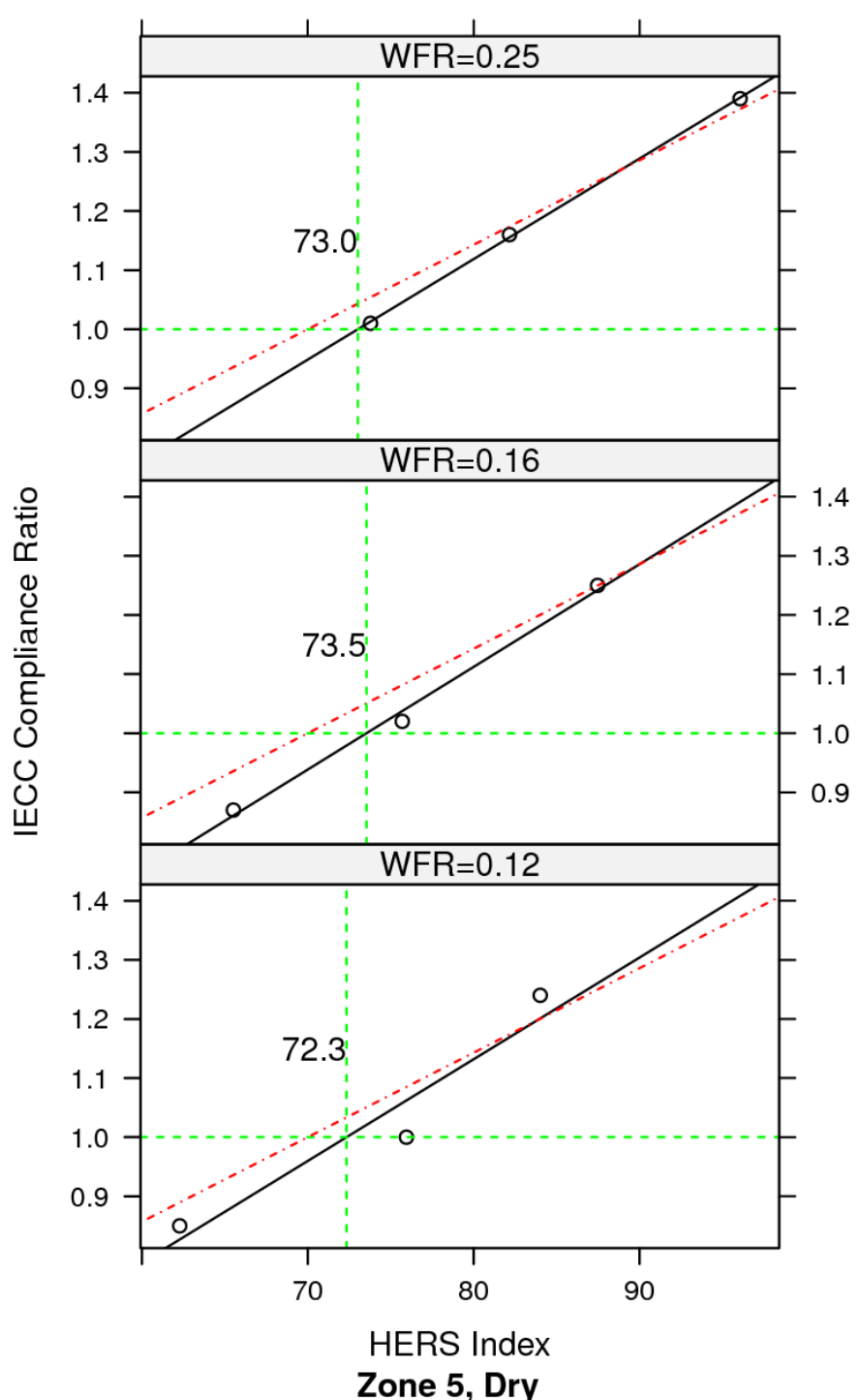

\section{Conditioned Floor Area}

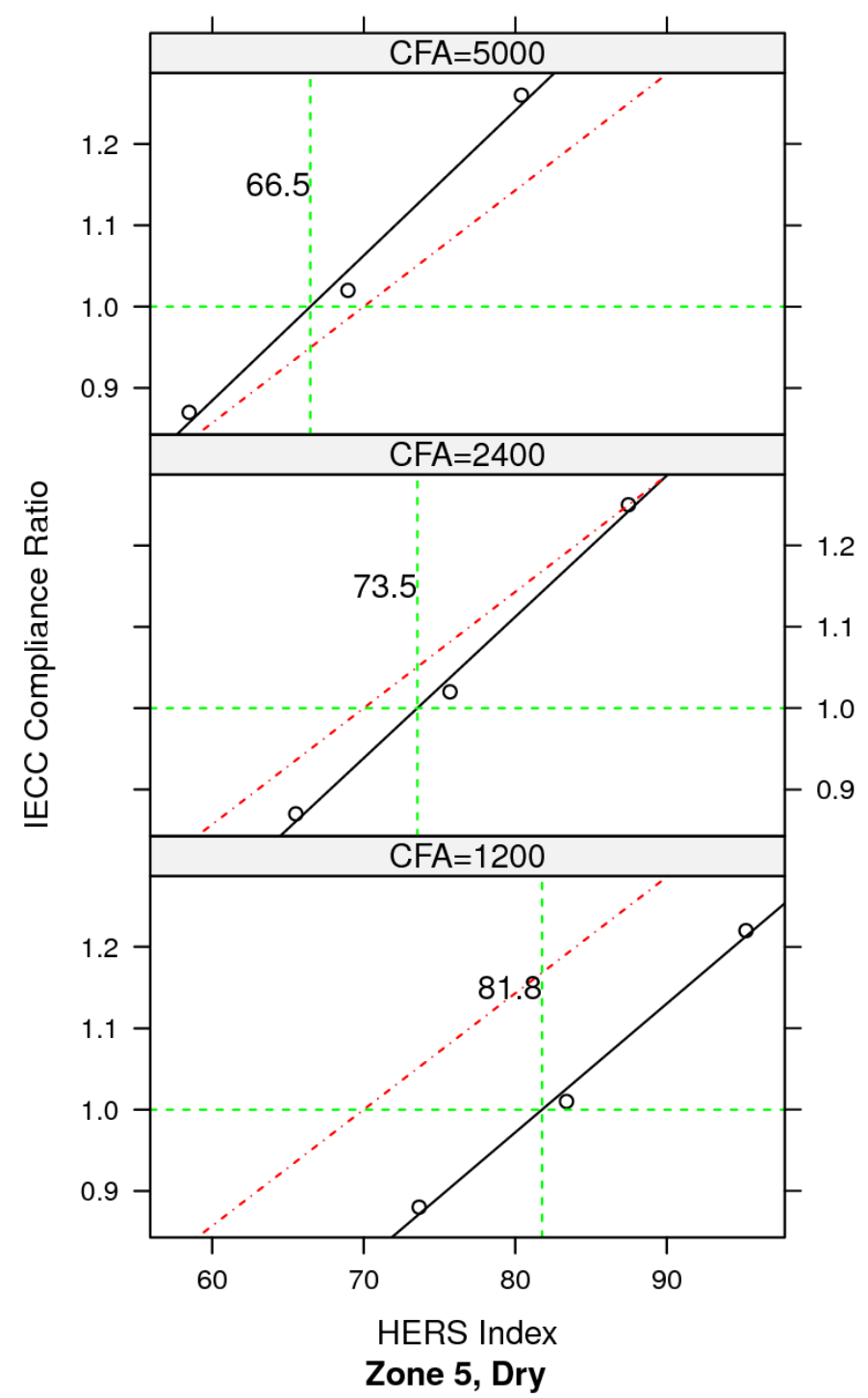

Figure A.11. Corresponding HERS Indexes for Climate Zone 5, Dry Regime (contd) 
Foundation

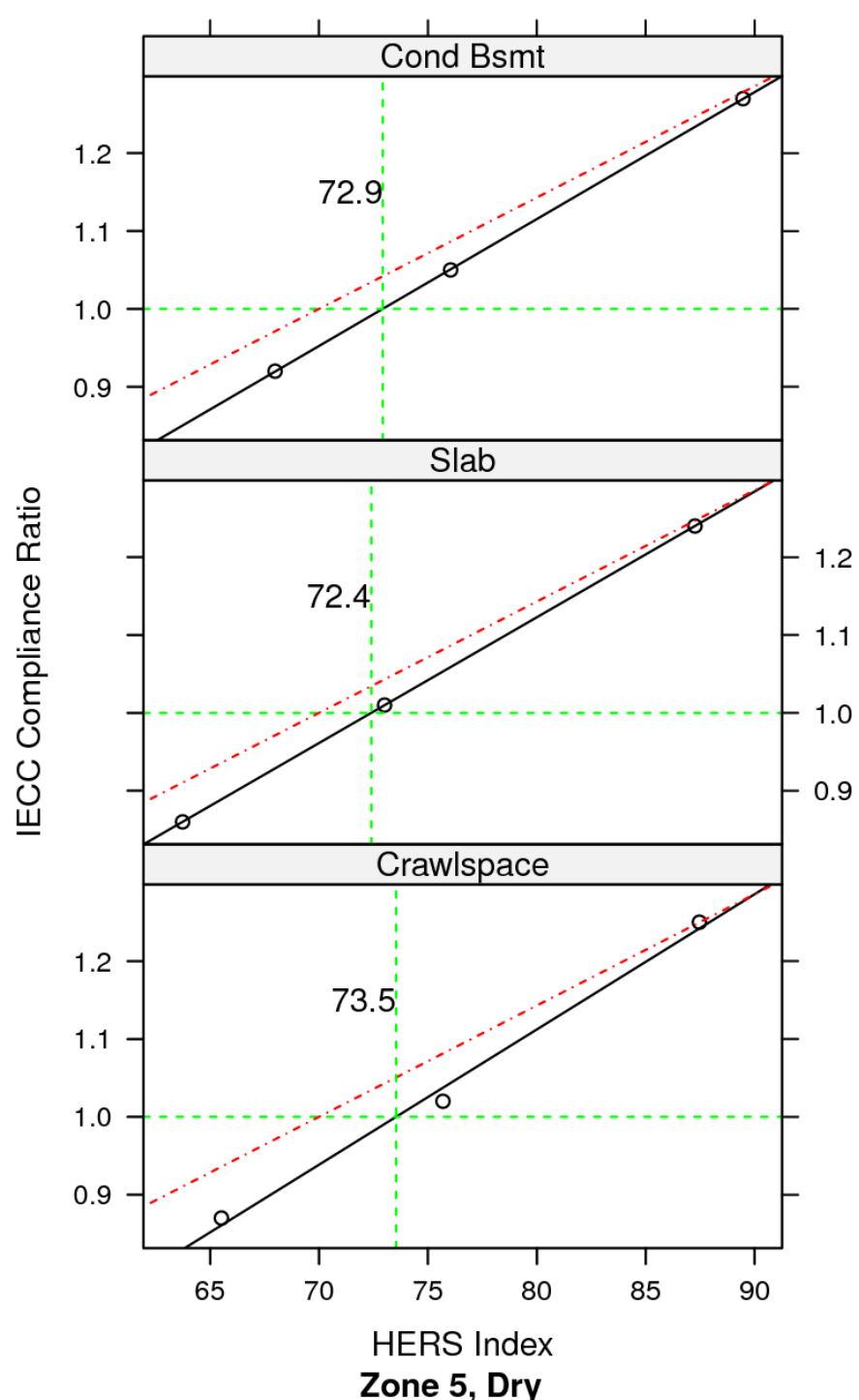

Appliances

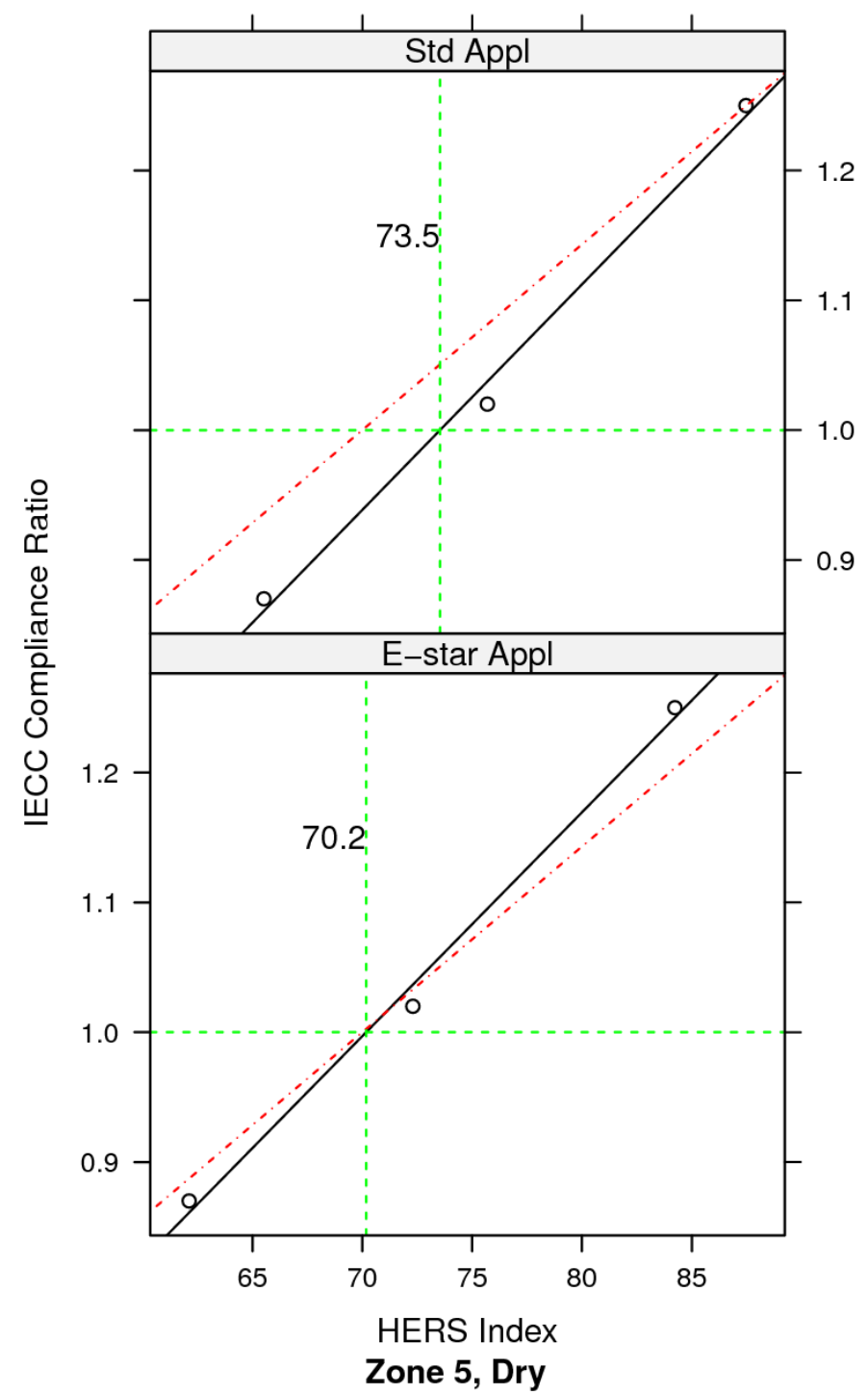

Figure A.11. Corresponding HERS Indexes for Climate Zone 5, Dry Regime (contd) 


\section{Glazing Orientation}

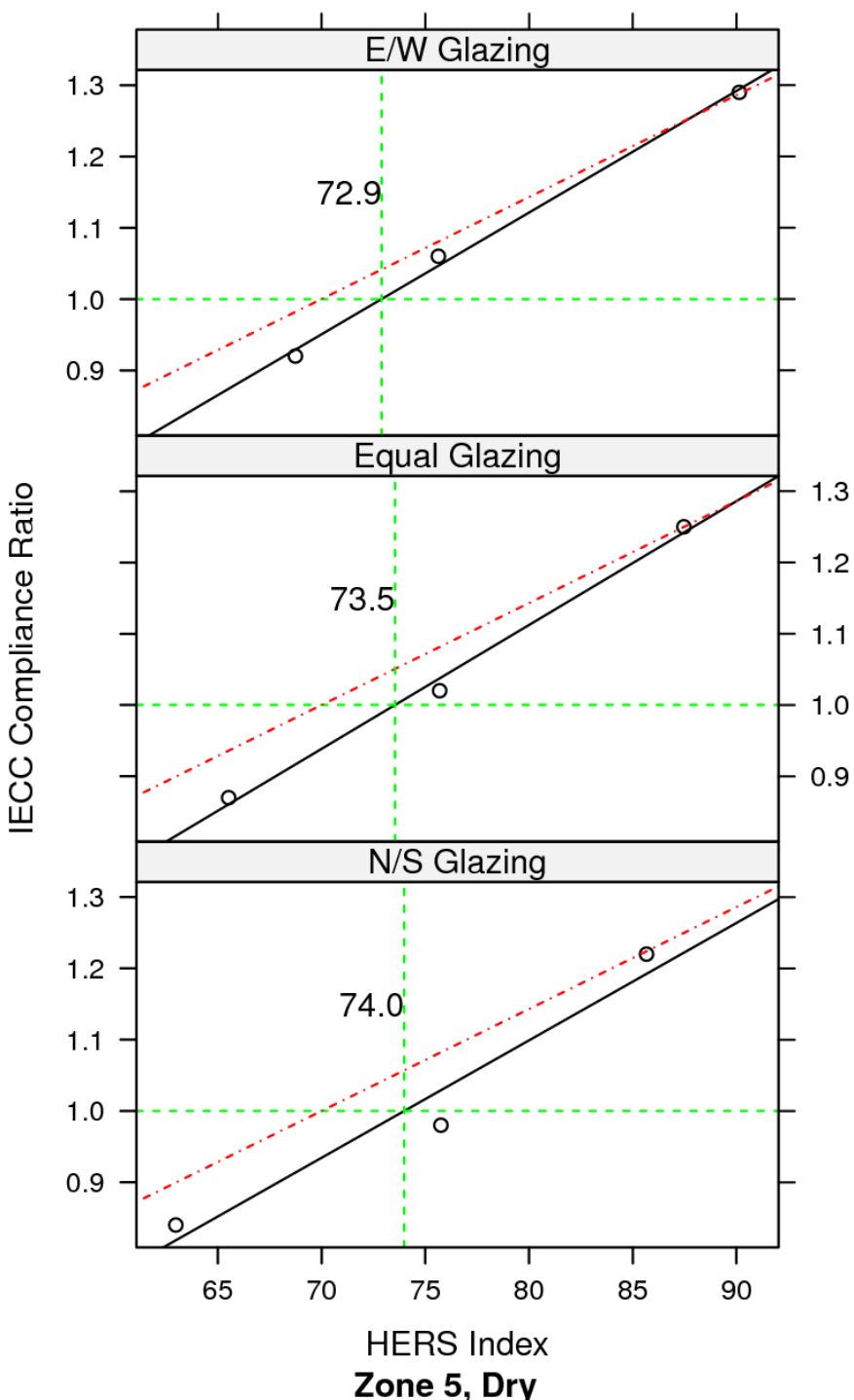

Number of Stories

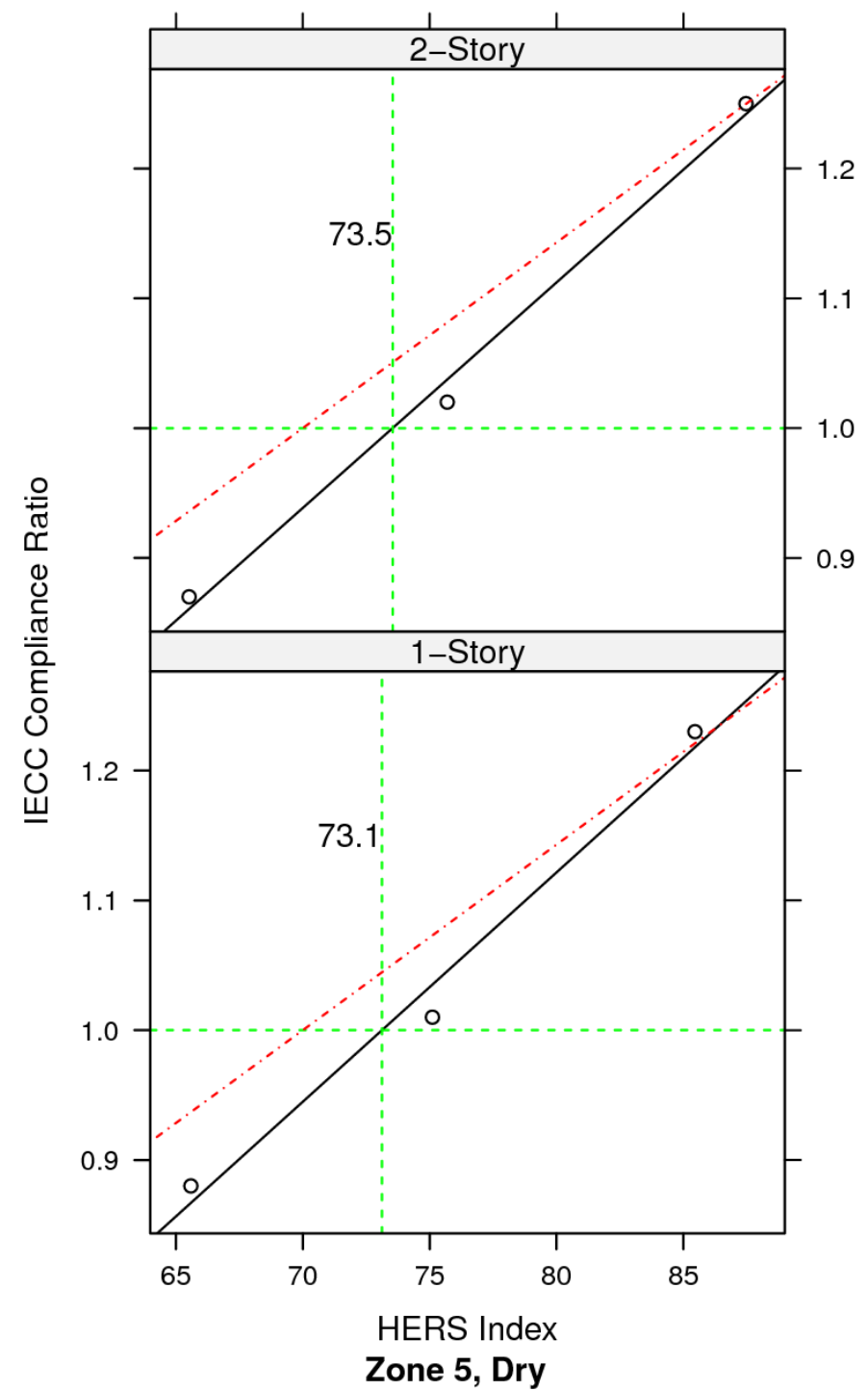

Figure A.11. Corresponding HERS Indexes for Climate Zone 5, Dry Regime (contd) 
Heat Pump Efficiency

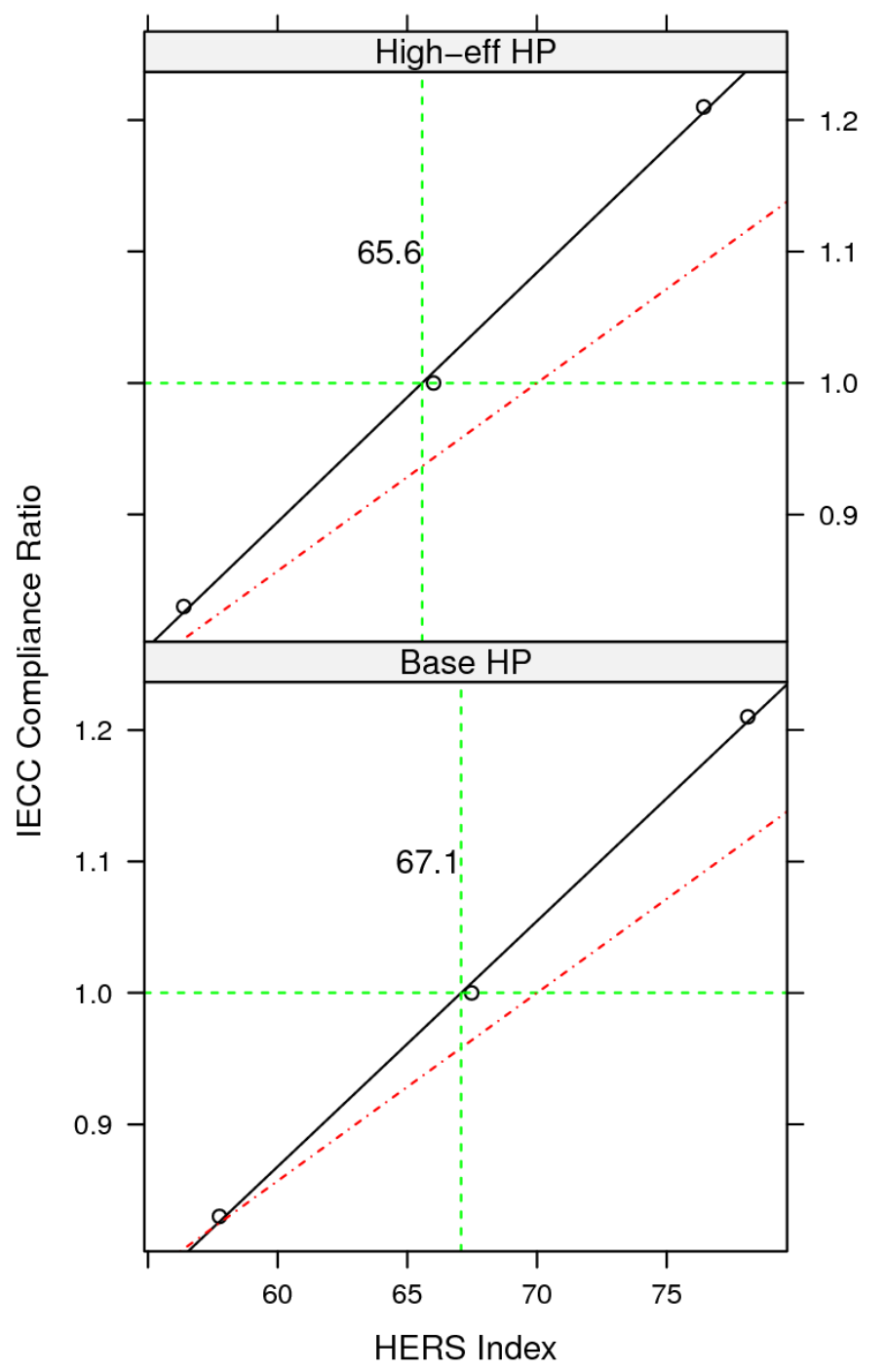

Zone 6, Moist
Gas Furnace \& AC Efficiency

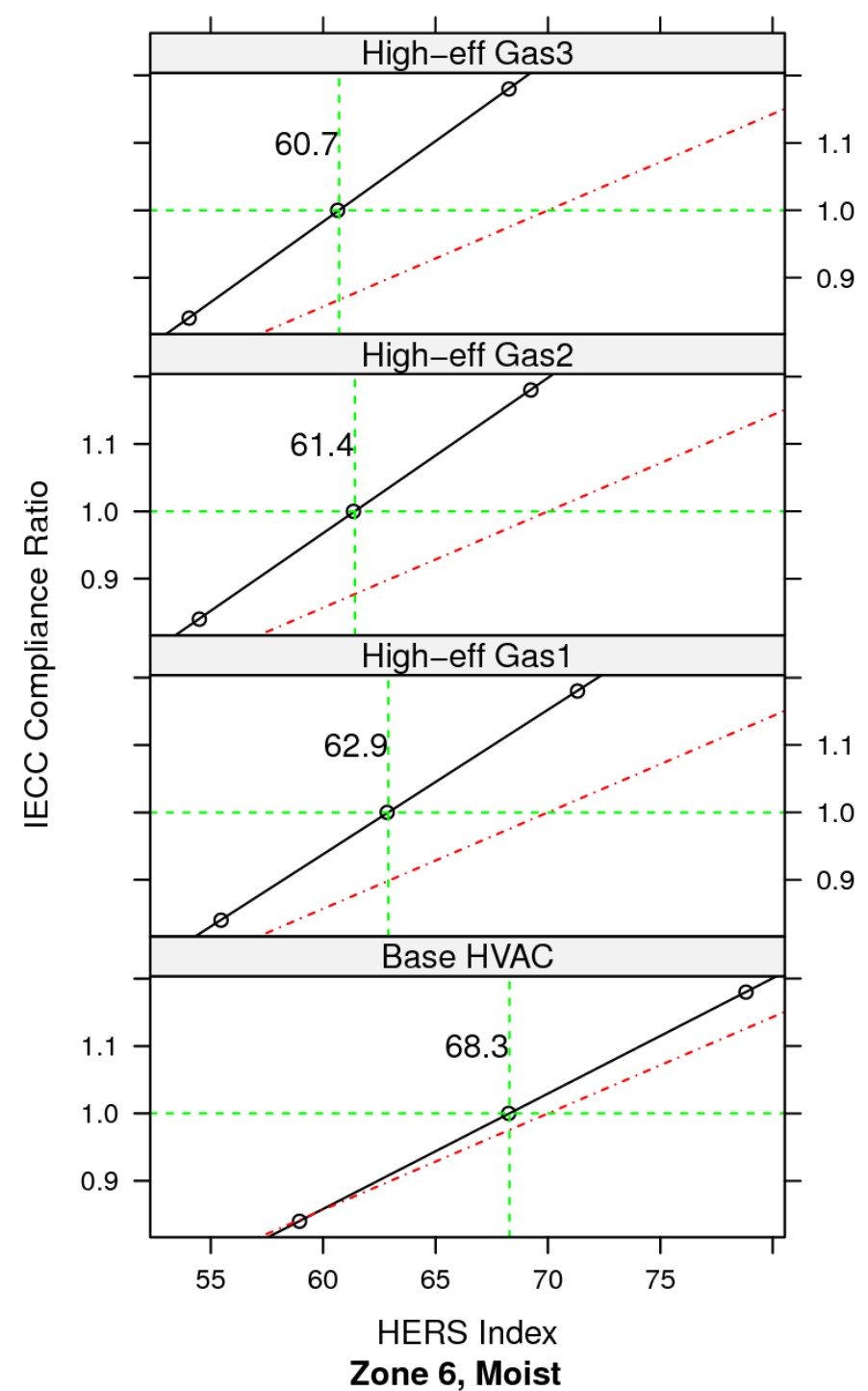

Figure A.12. Corresponding HERS Indexes for Climate Zone 6, Moist Regime 
Window-Floor Ratio

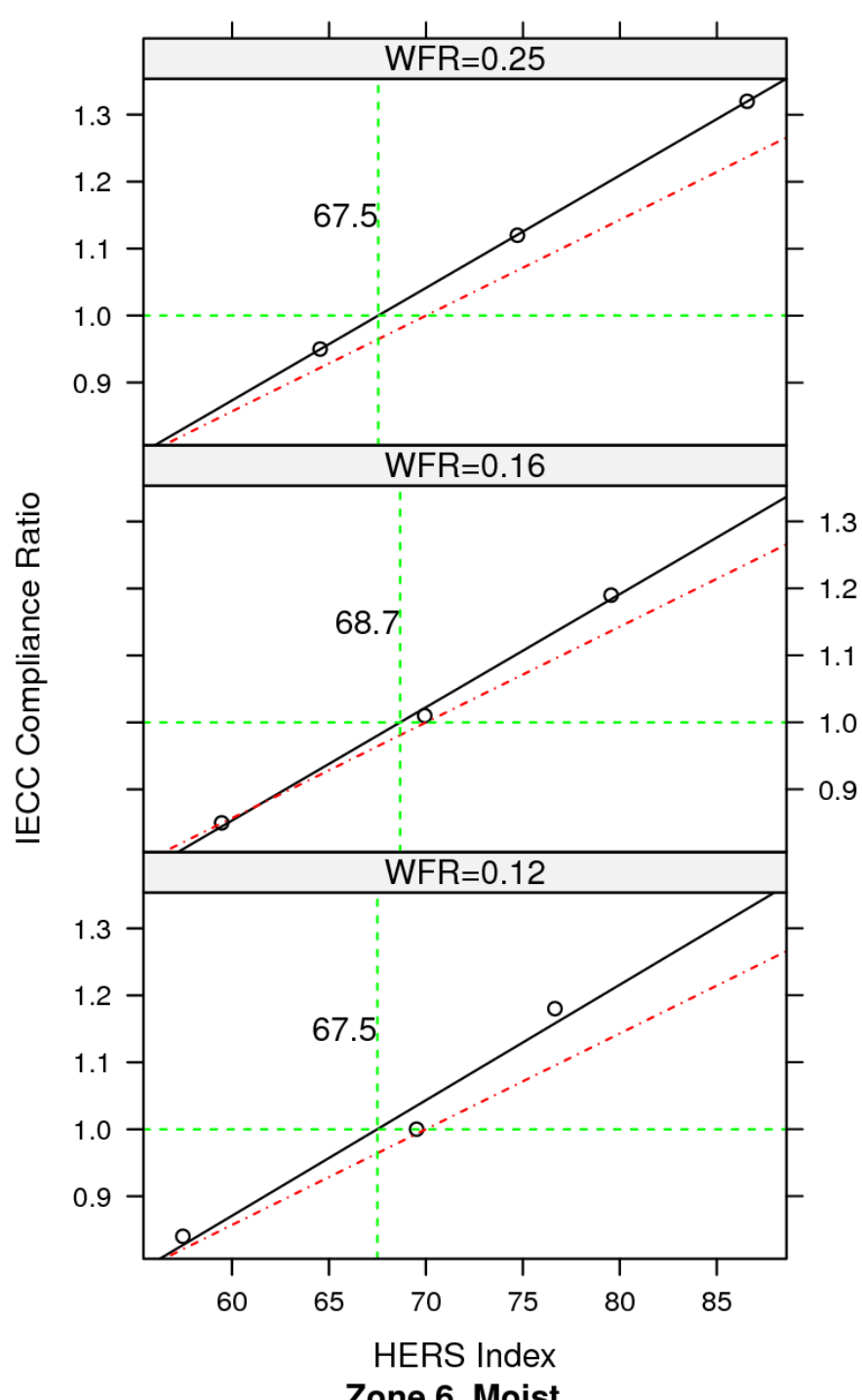

\section{Conditioned Floor Area}

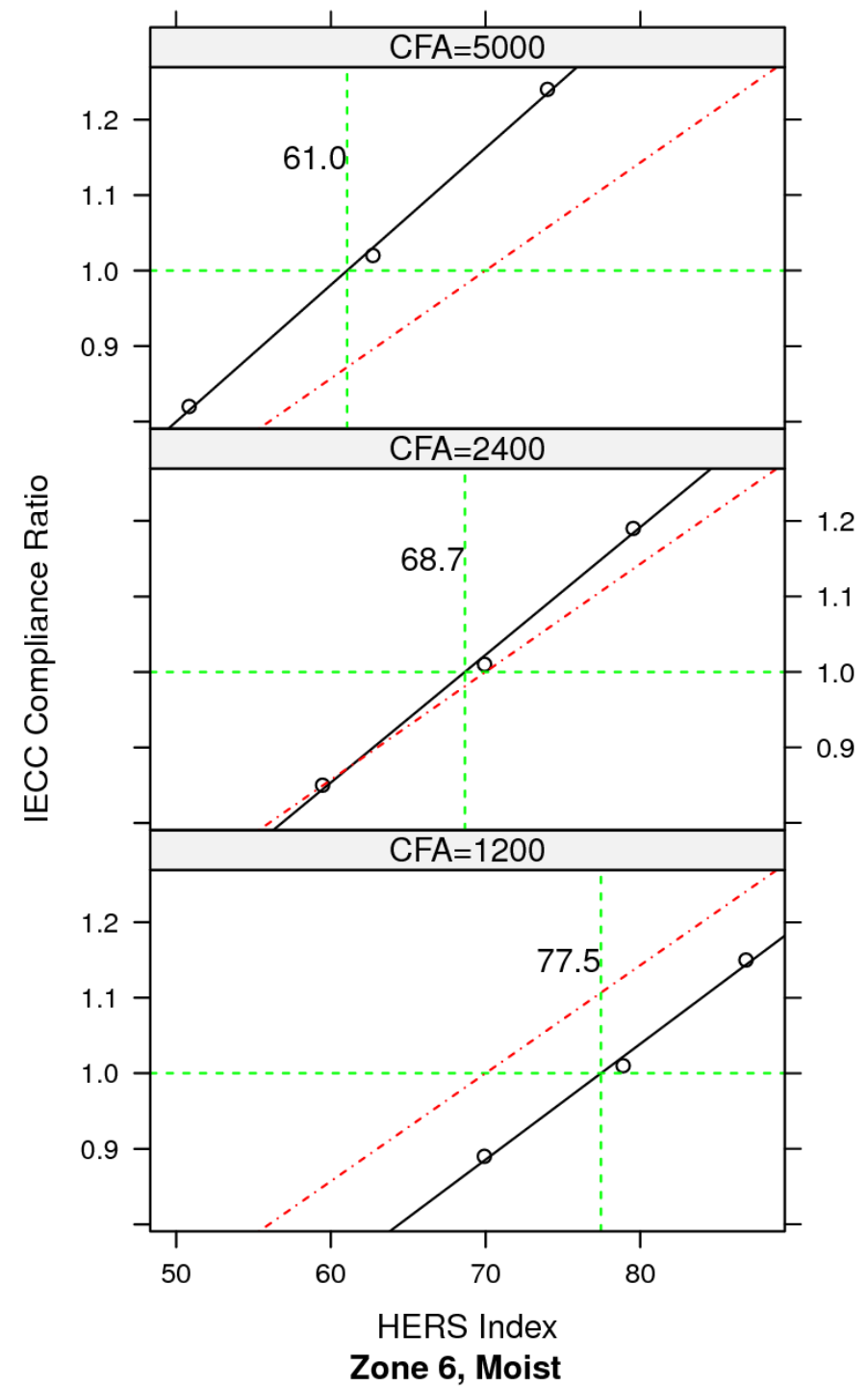

Figure A.12. Corresponding HERS Indexes for Climate Zone 6, Moist Regime (contd) 
Foundation

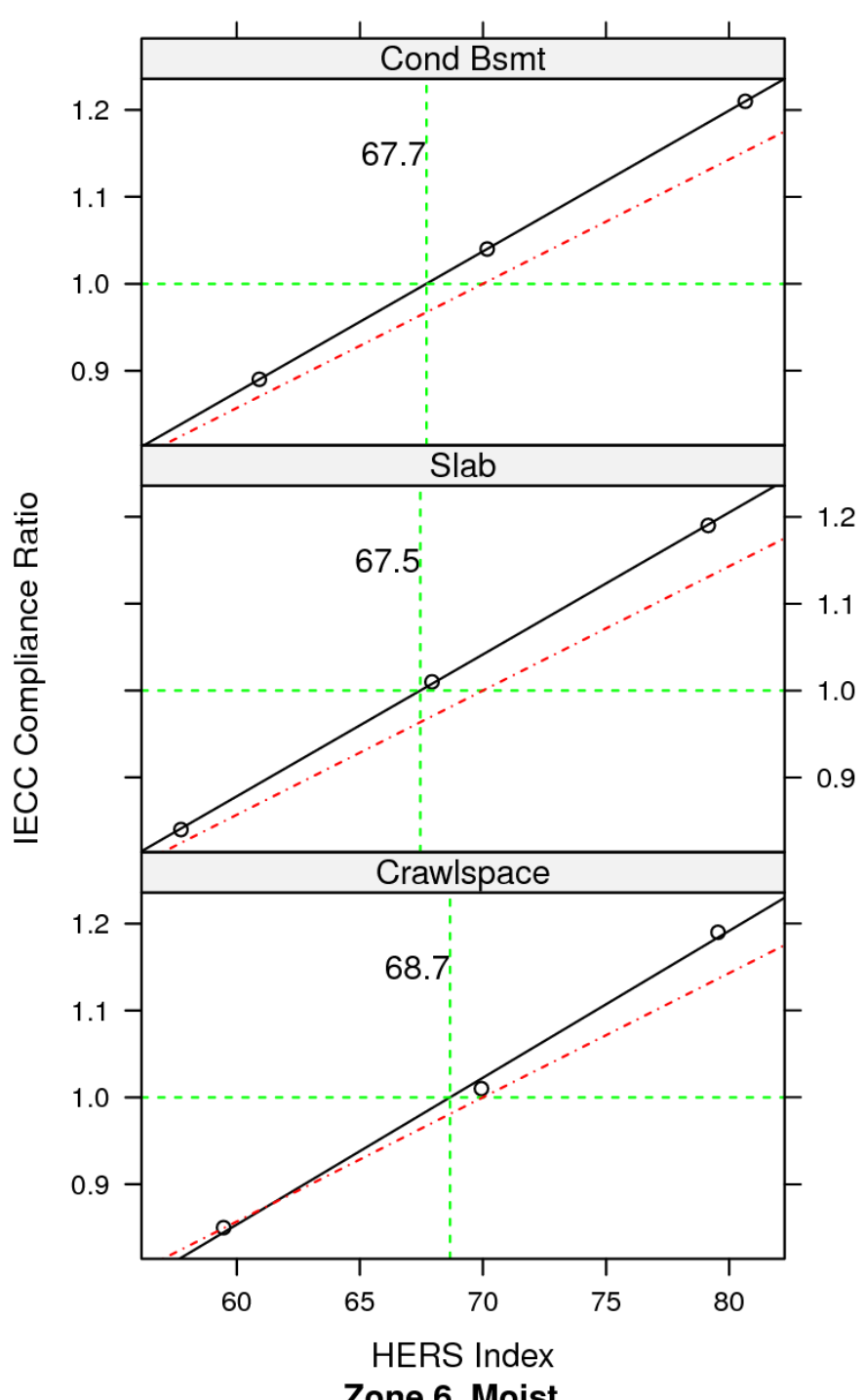

Appliances

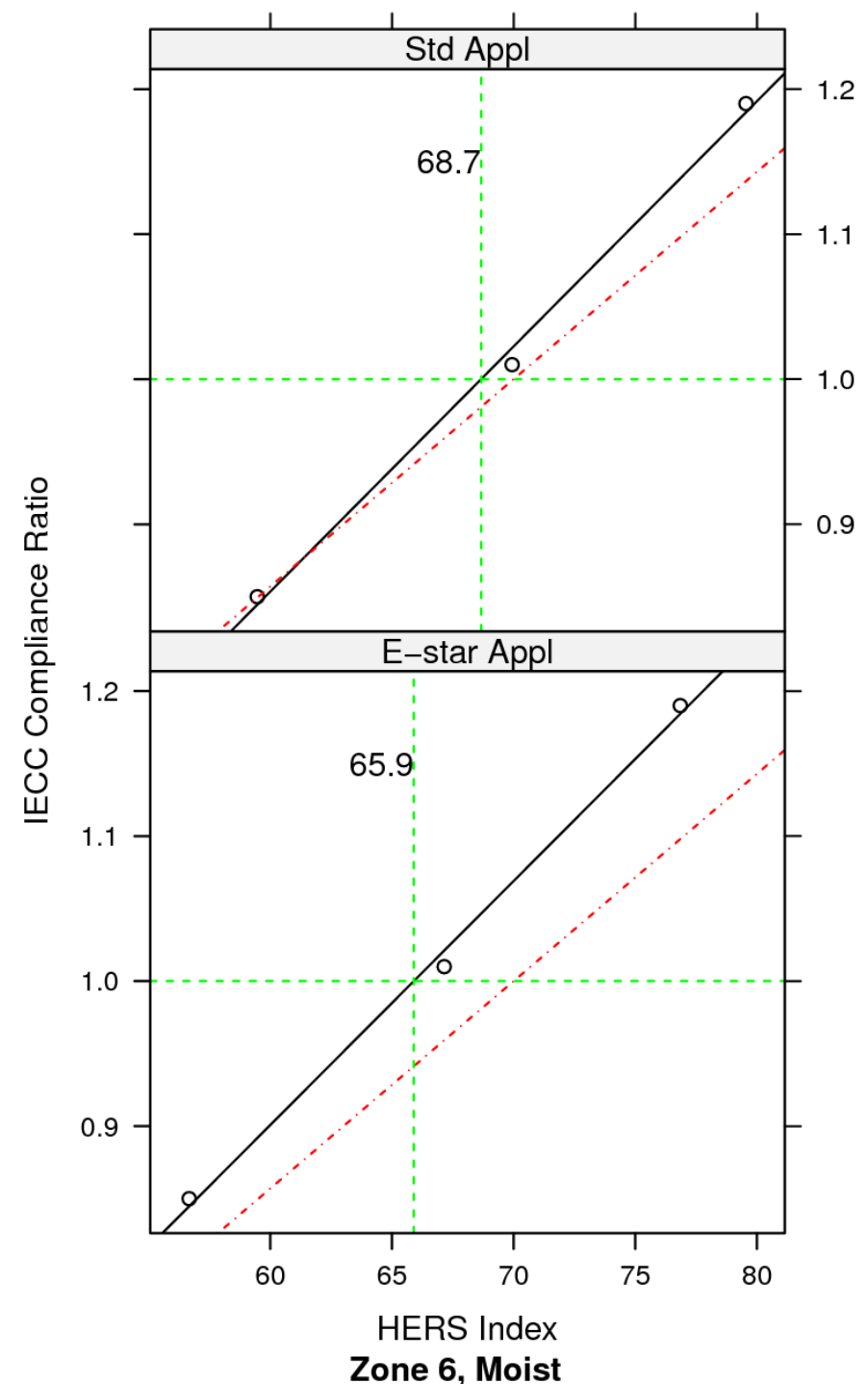

Figure A.12. Corresponding HERS Indexes for Climate Zone 6, Moist Regime (contd) 


\section{Glazing Orientation}

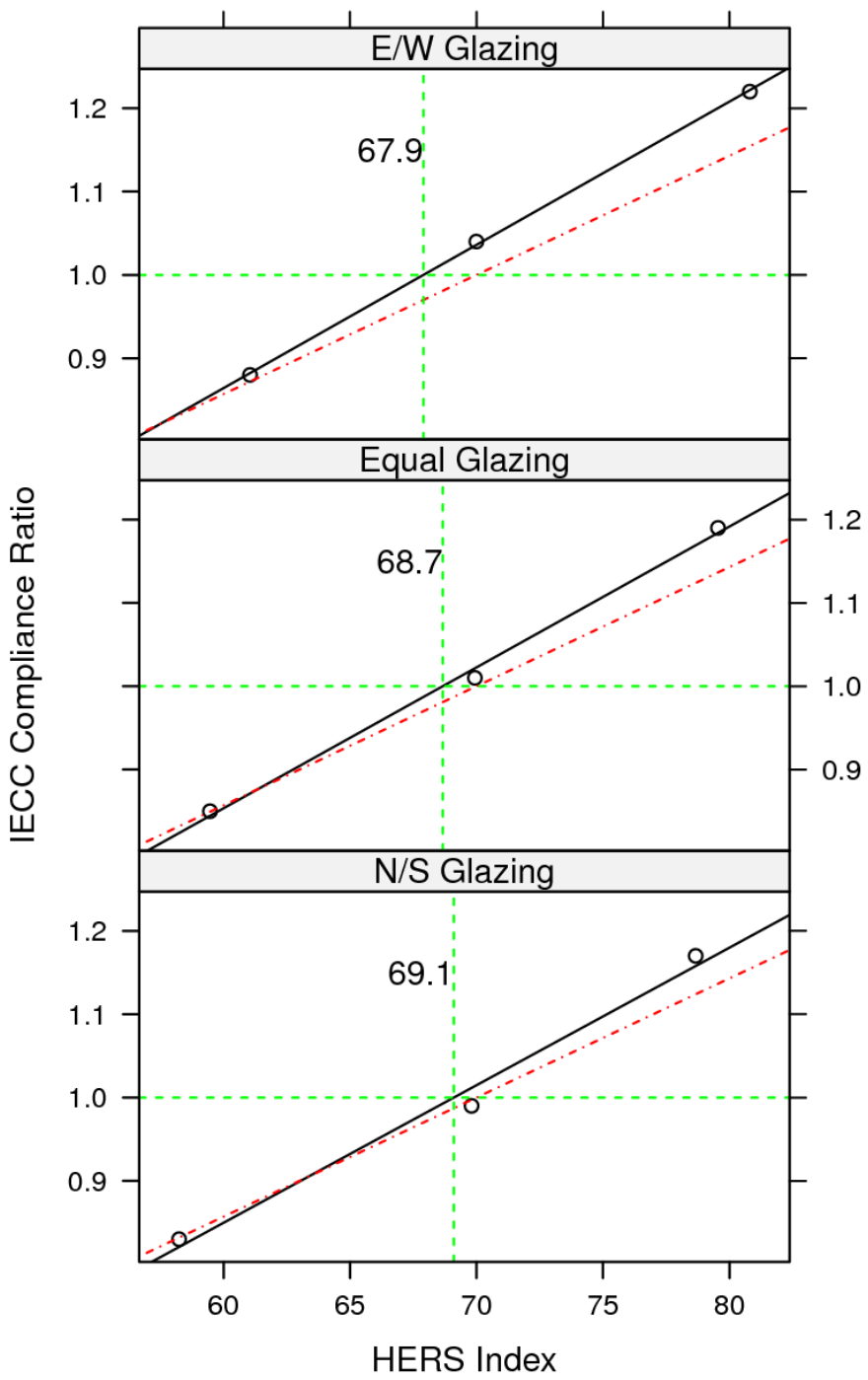

Zone 6, Moist

\section{Number of Stories}

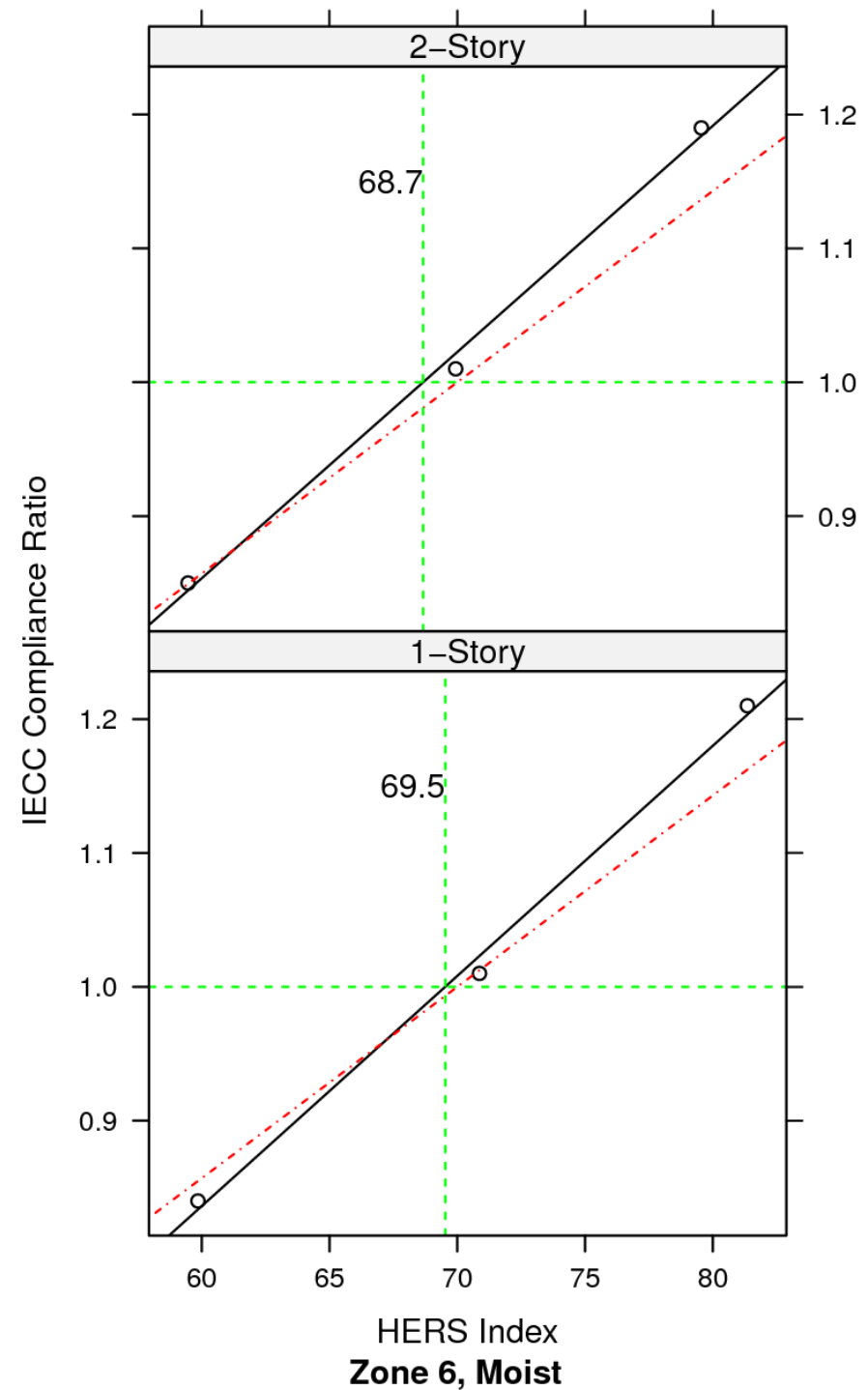

Figure A.12. Corresponding HERS Indexes for Climate Zone 6, Moist Regime (contd) 


\section{Heat Pump Efficiency}

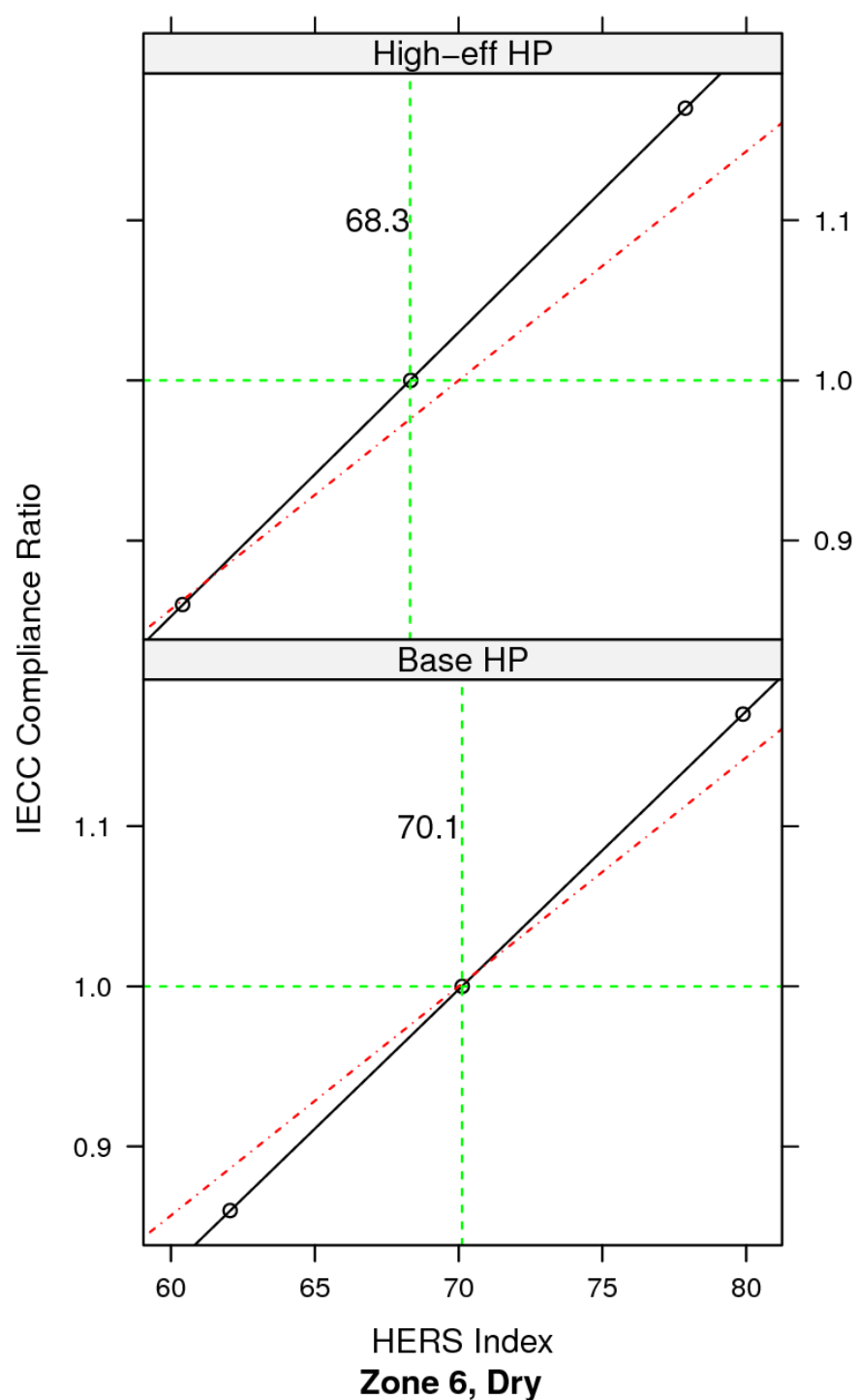

Gas Furnace \& AC Efficiency

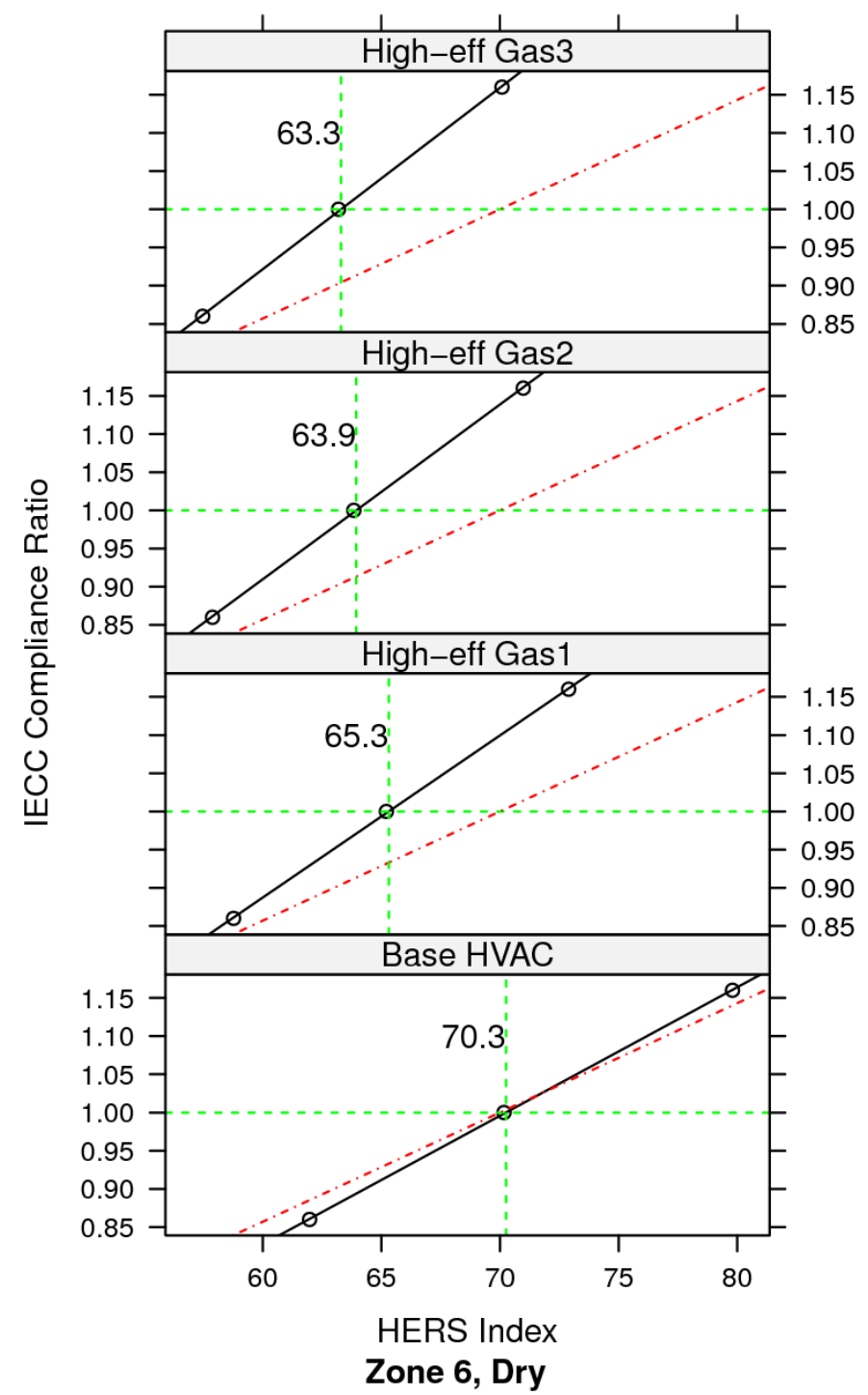

Figure A.13. Corresponding HERS Indexes for Climate Zone 6, Dry Regime 
Window-Floor Ratio

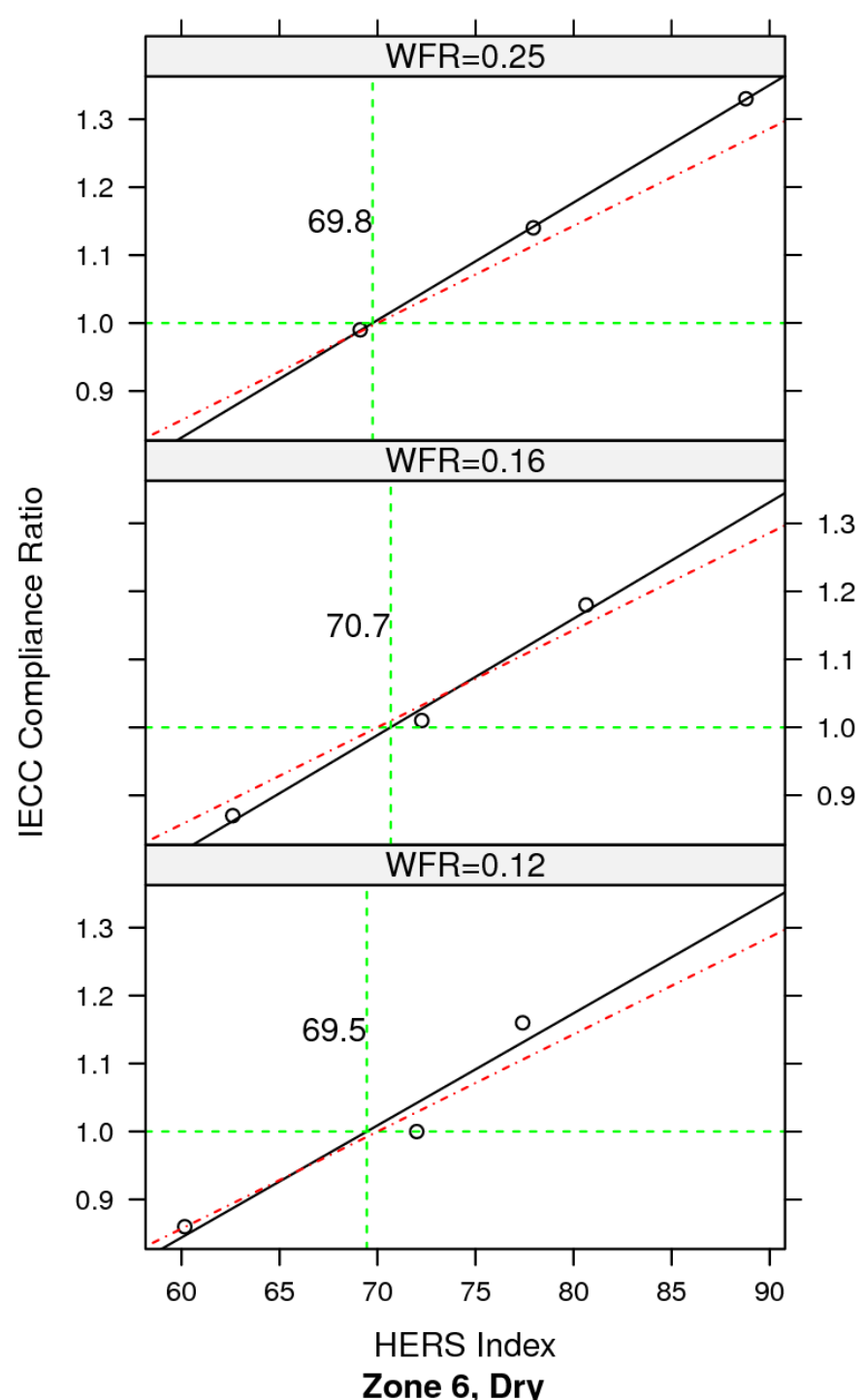

\section{Conditioned Floor Area}

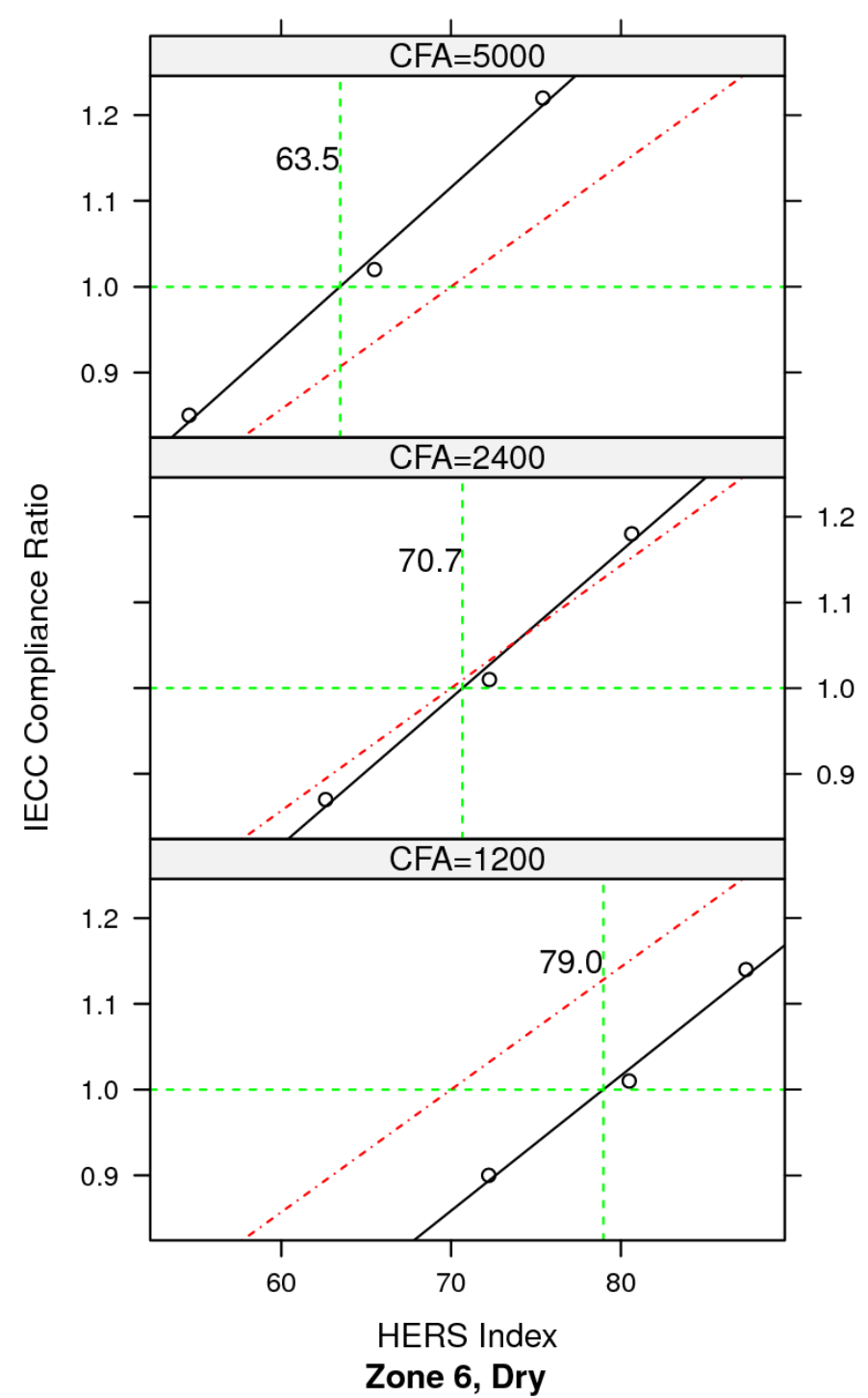

Figure A.13. Corresponding HERS Indexes for Climate Zone 6, Dry Regime (contd) 
Foundation

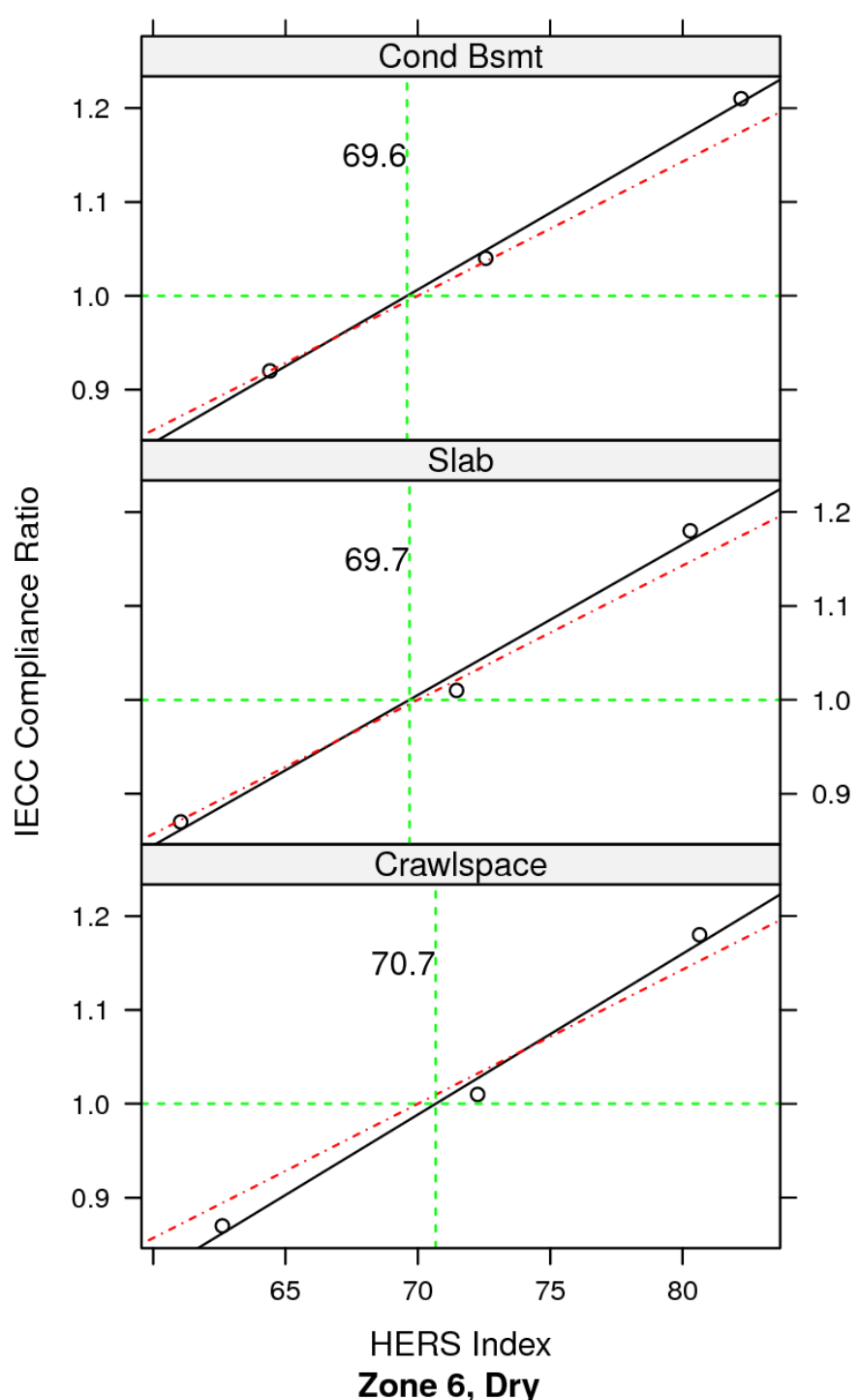

Appliances

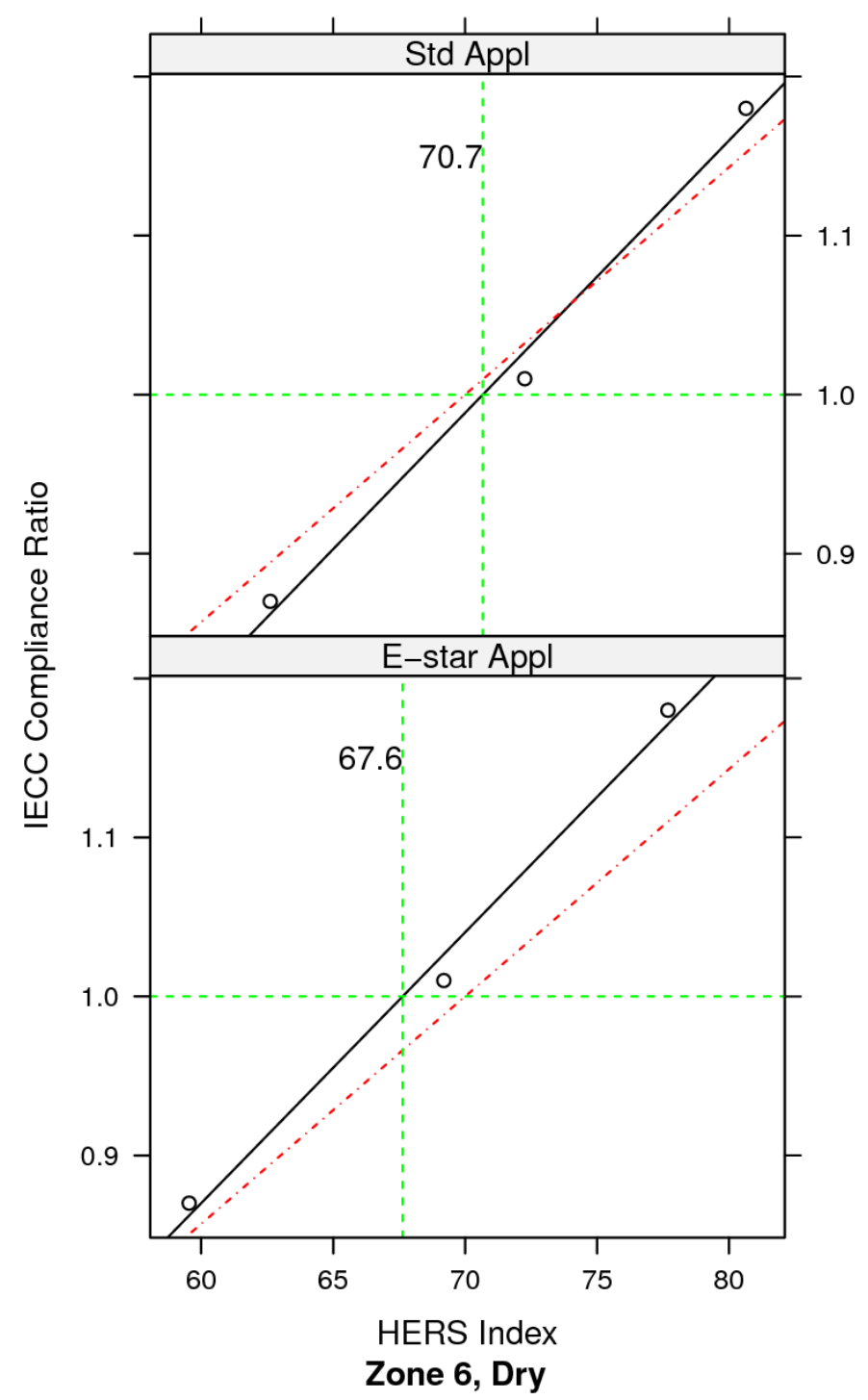

Figure A.13. Corresponding HERS Indexes for Climate Zone 6, Dry Regime (contd) 


\section{Glazing Orientation}

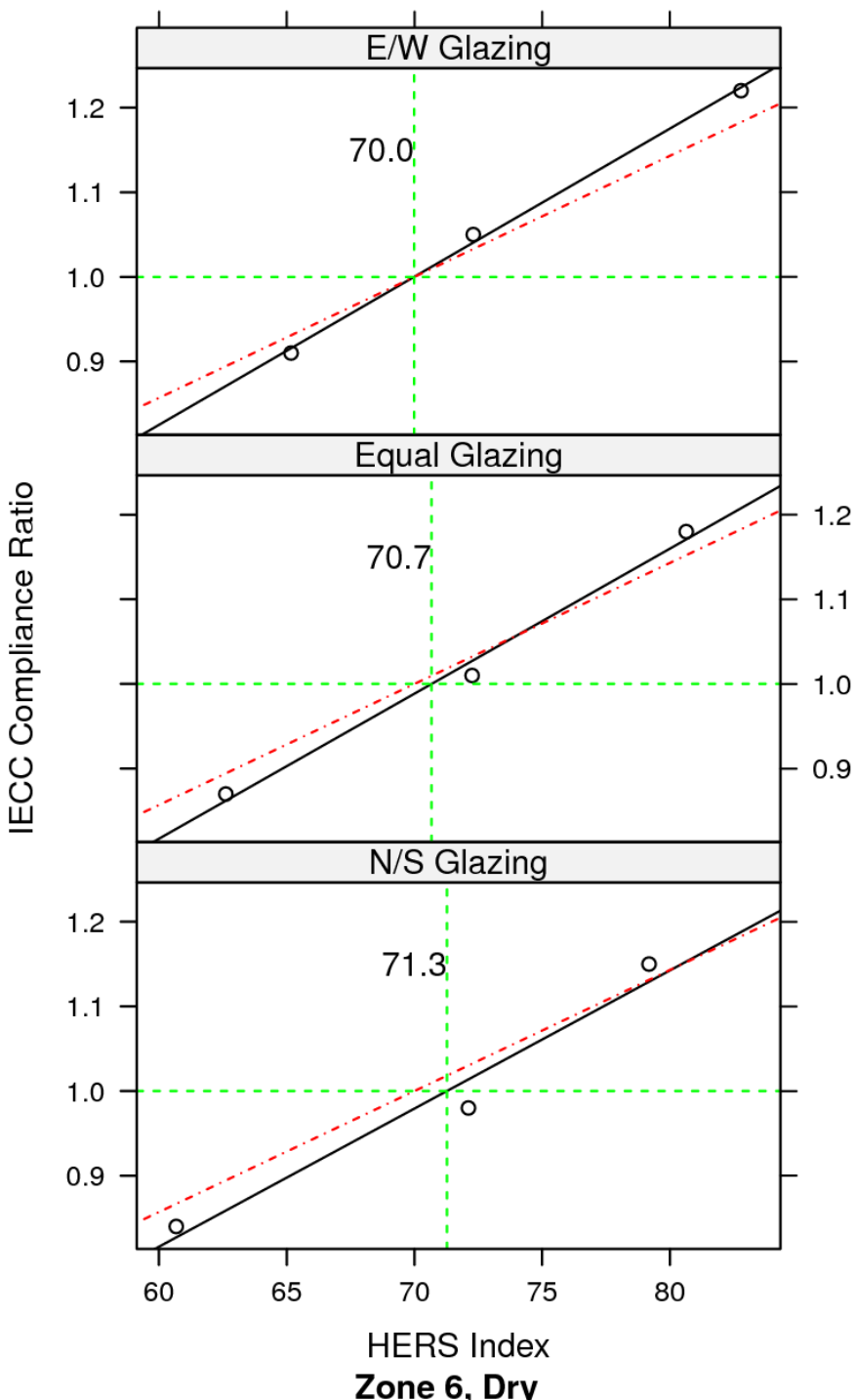

Number of Stories

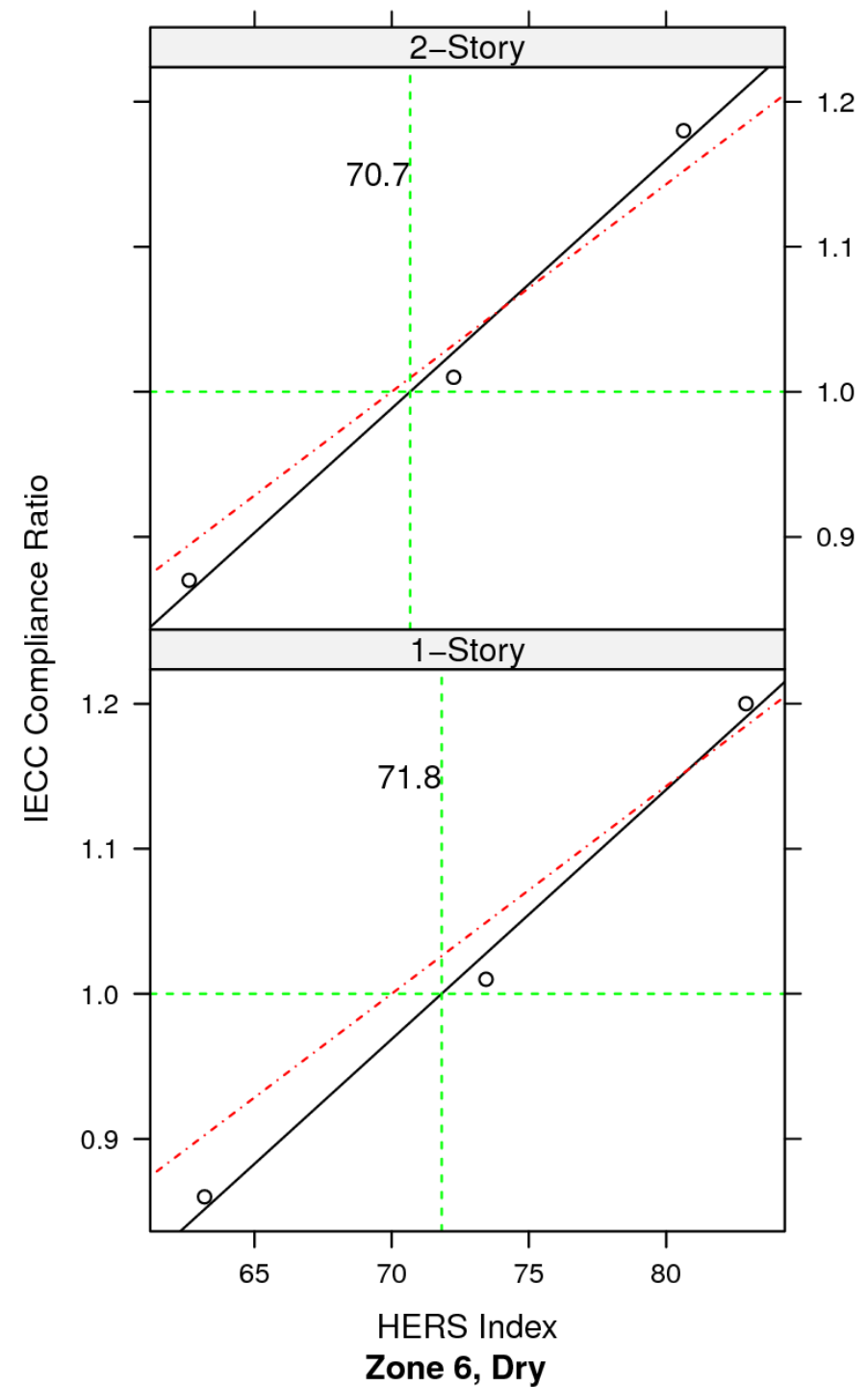

Figure A.13. Corresponding HERS Indexes for Climate Zone 6, Dry Regime (contd) 


\section{Heat Pump Efficiency}

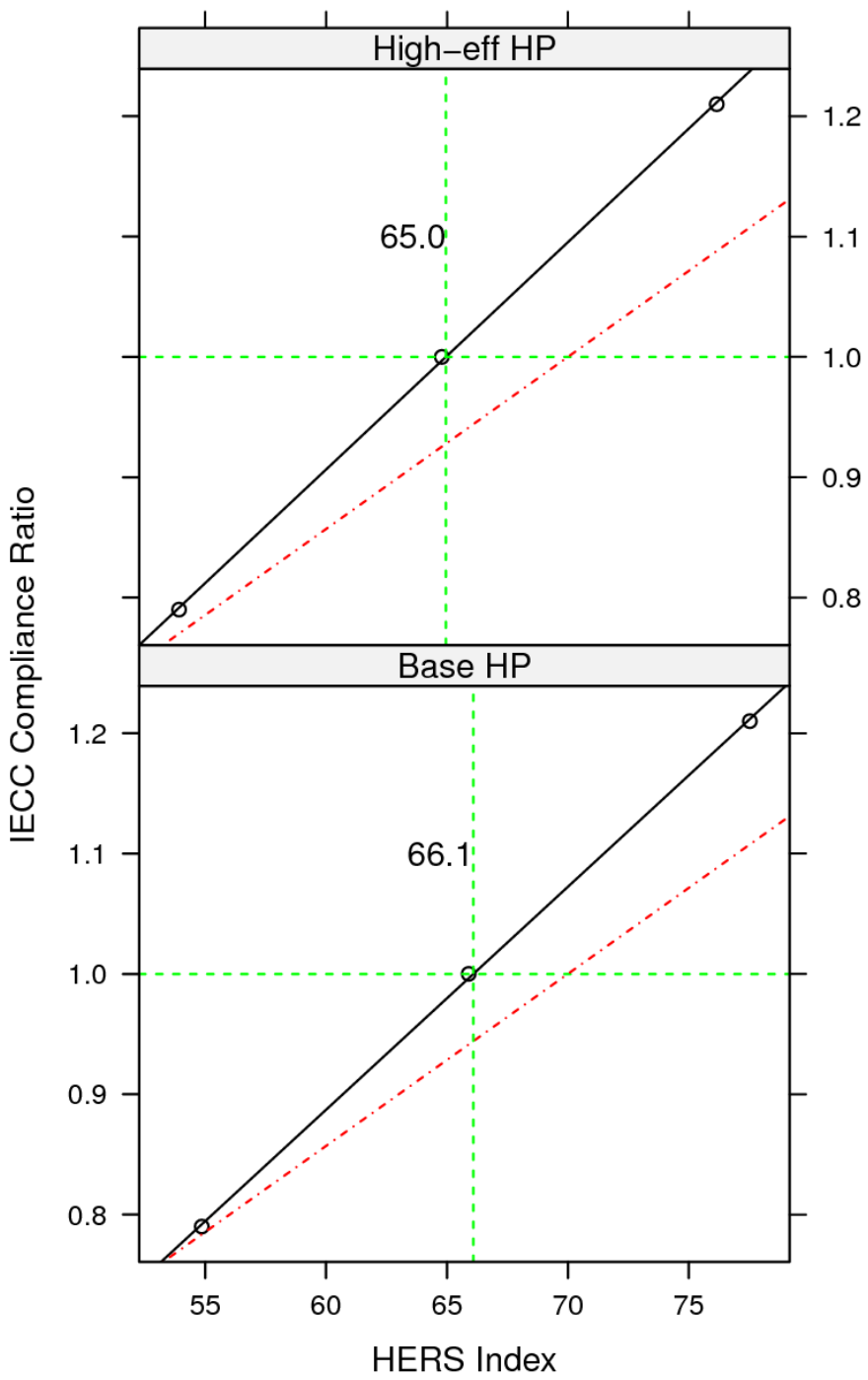

Zone 7, None
Gas Furnace \& AC Efficiency

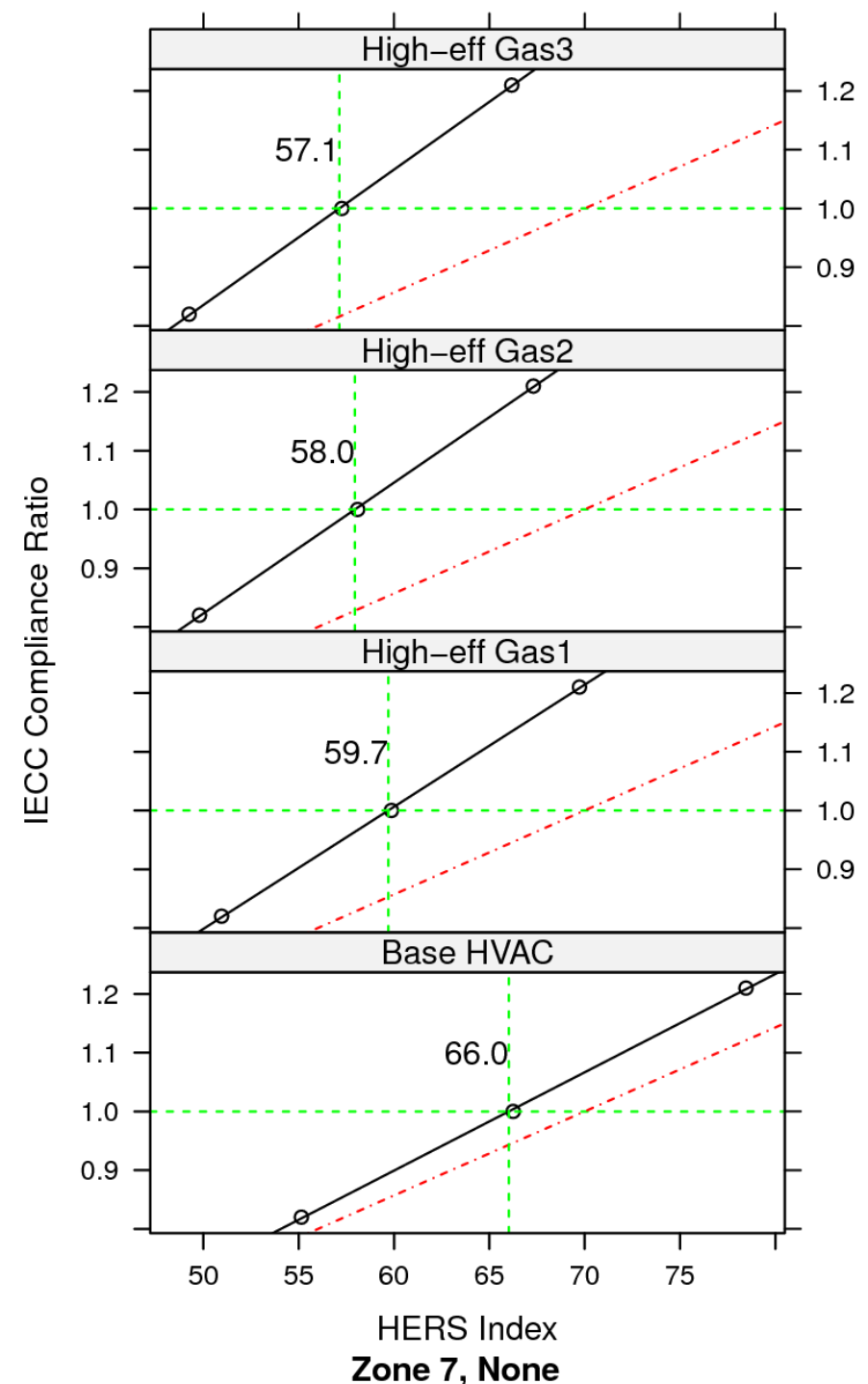

Figure A.14. Corresponding HERS Indexes for Climate Zone 7 
Window-Floor Ratio

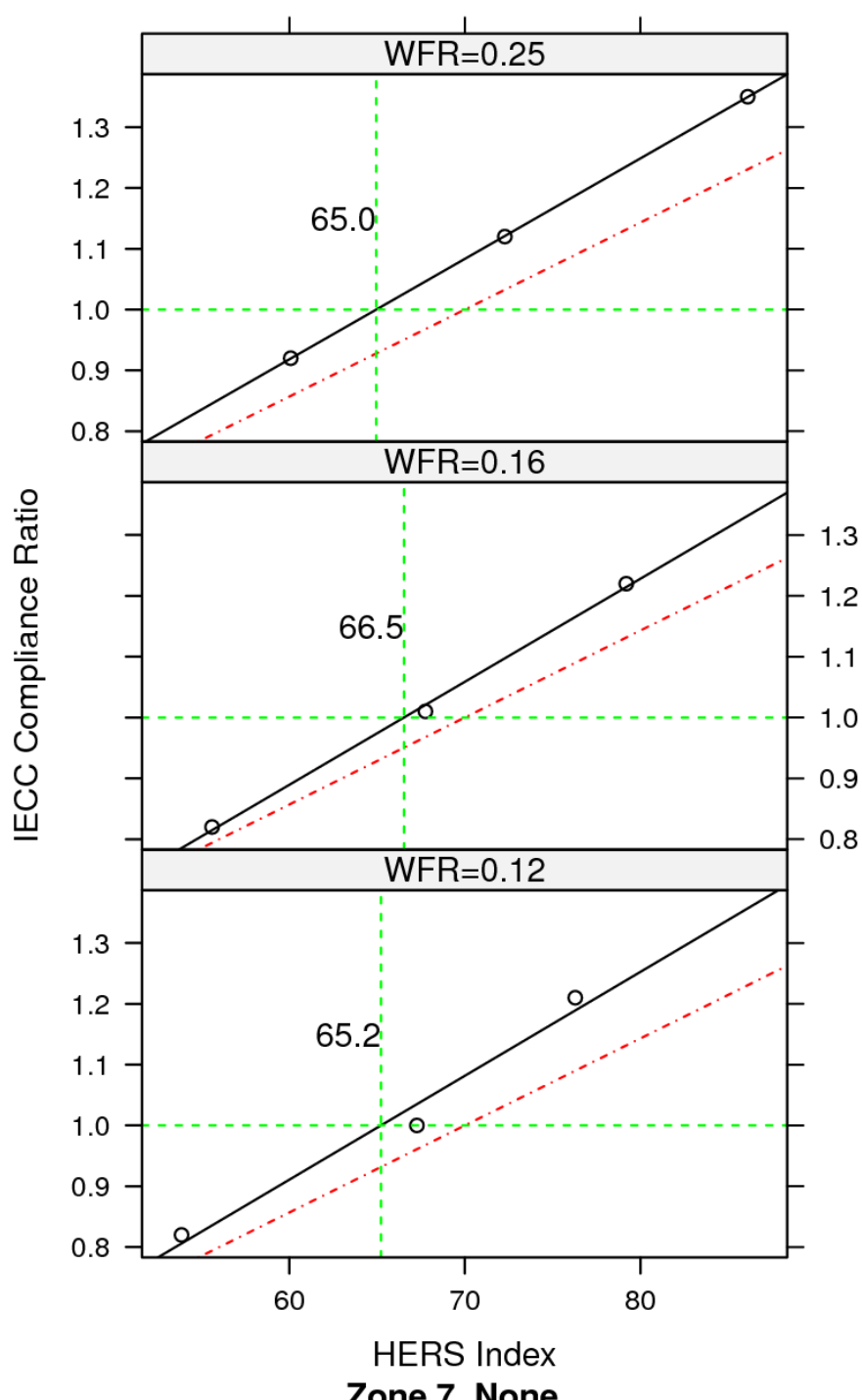

Conditioned Floor Area

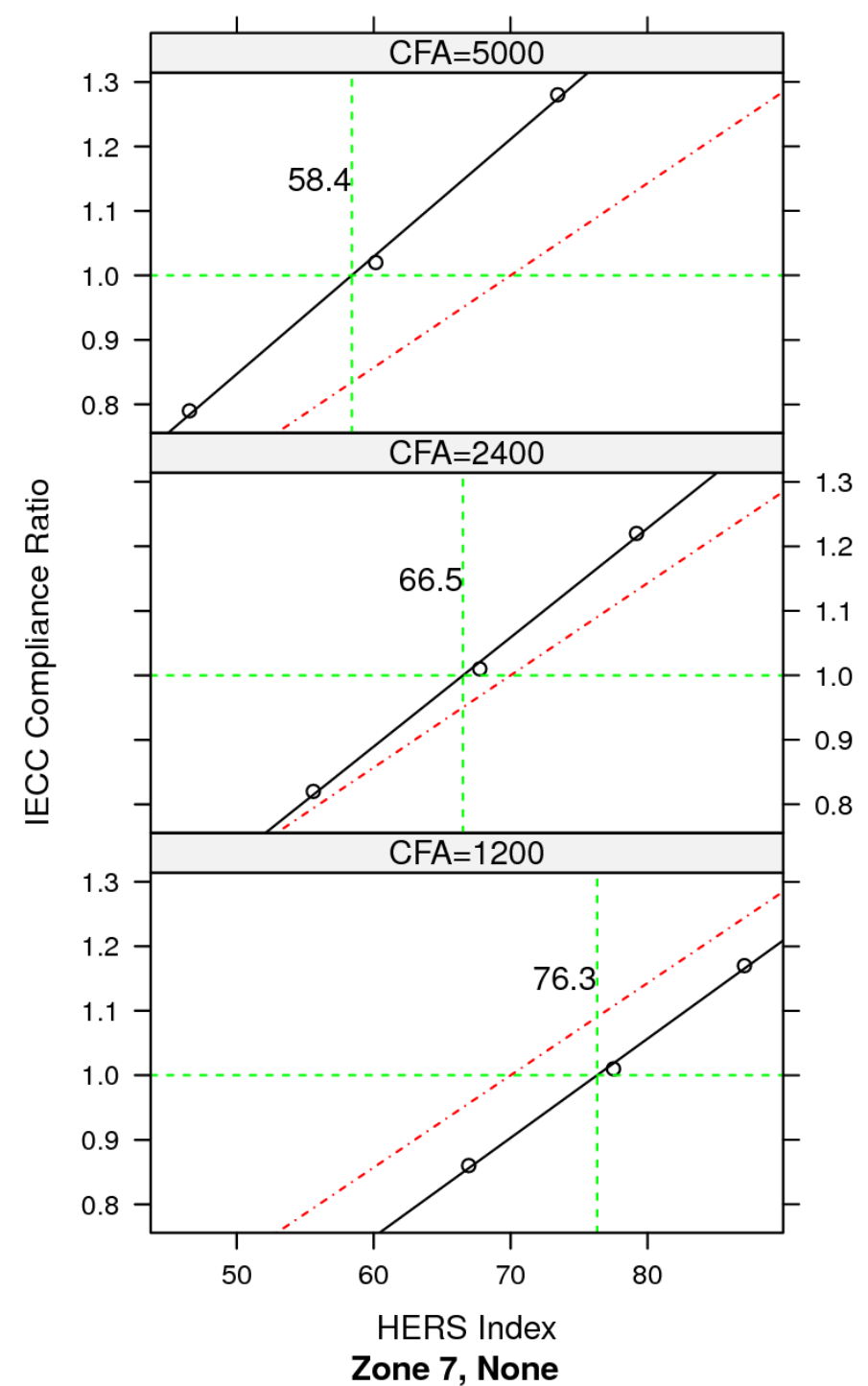

Figure A.14. Corresponding HERS Indexes for Climate Zone 7 (contd) 
Foundation

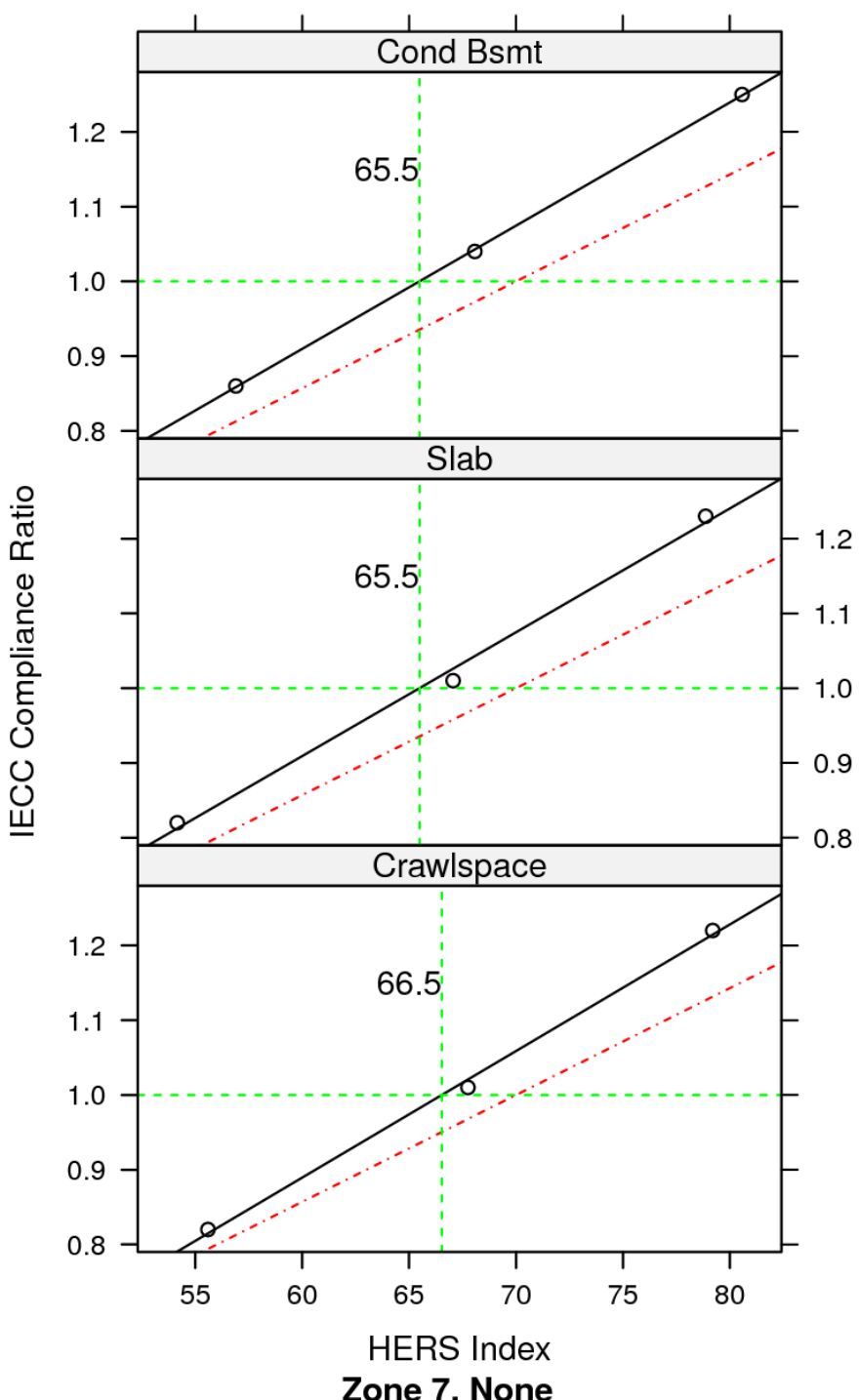

Appliances

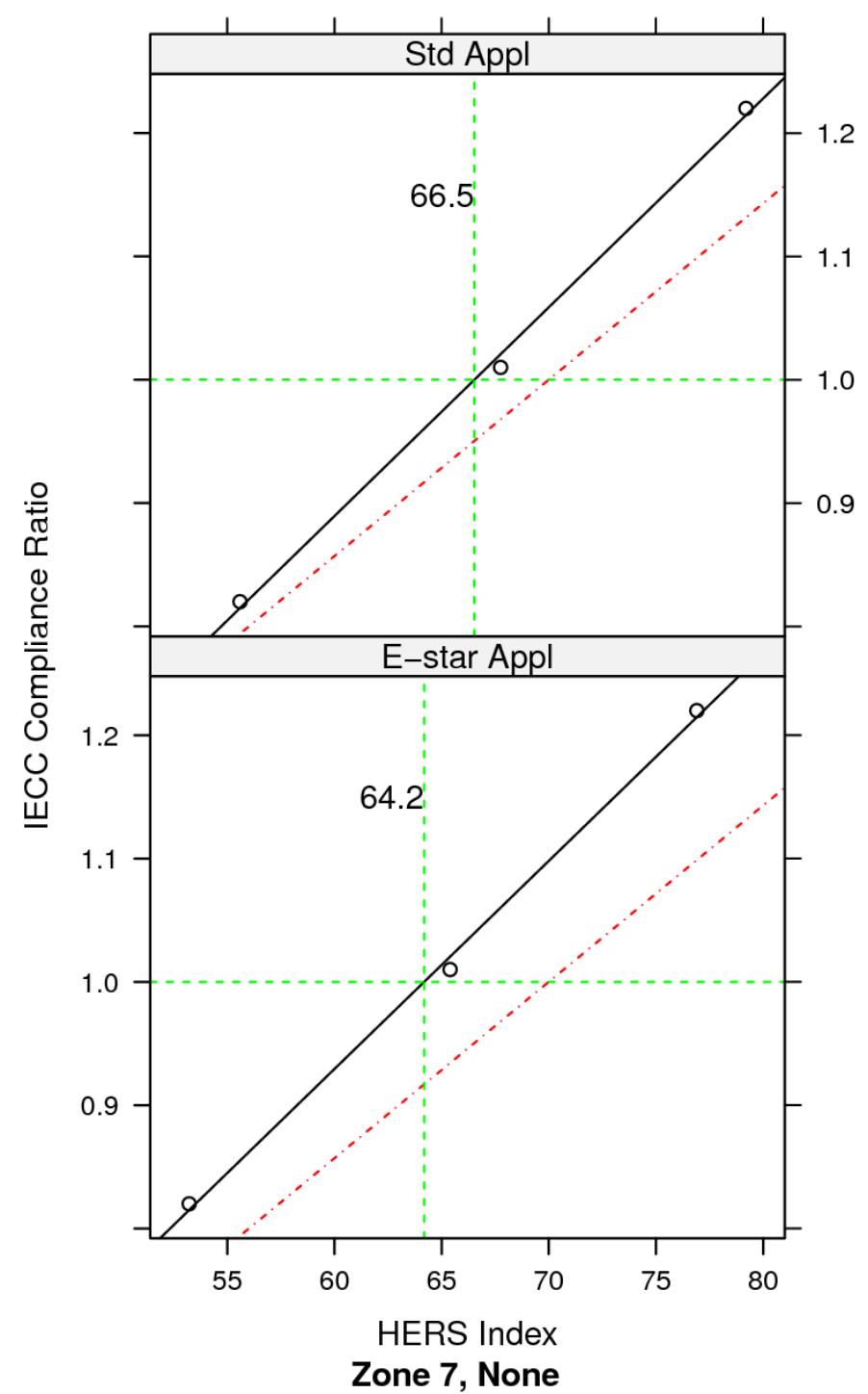

Figure A.14. Corresponding HERS Indexes for Climate Zone 7 (contd) 


\section{Glazing Orientation}

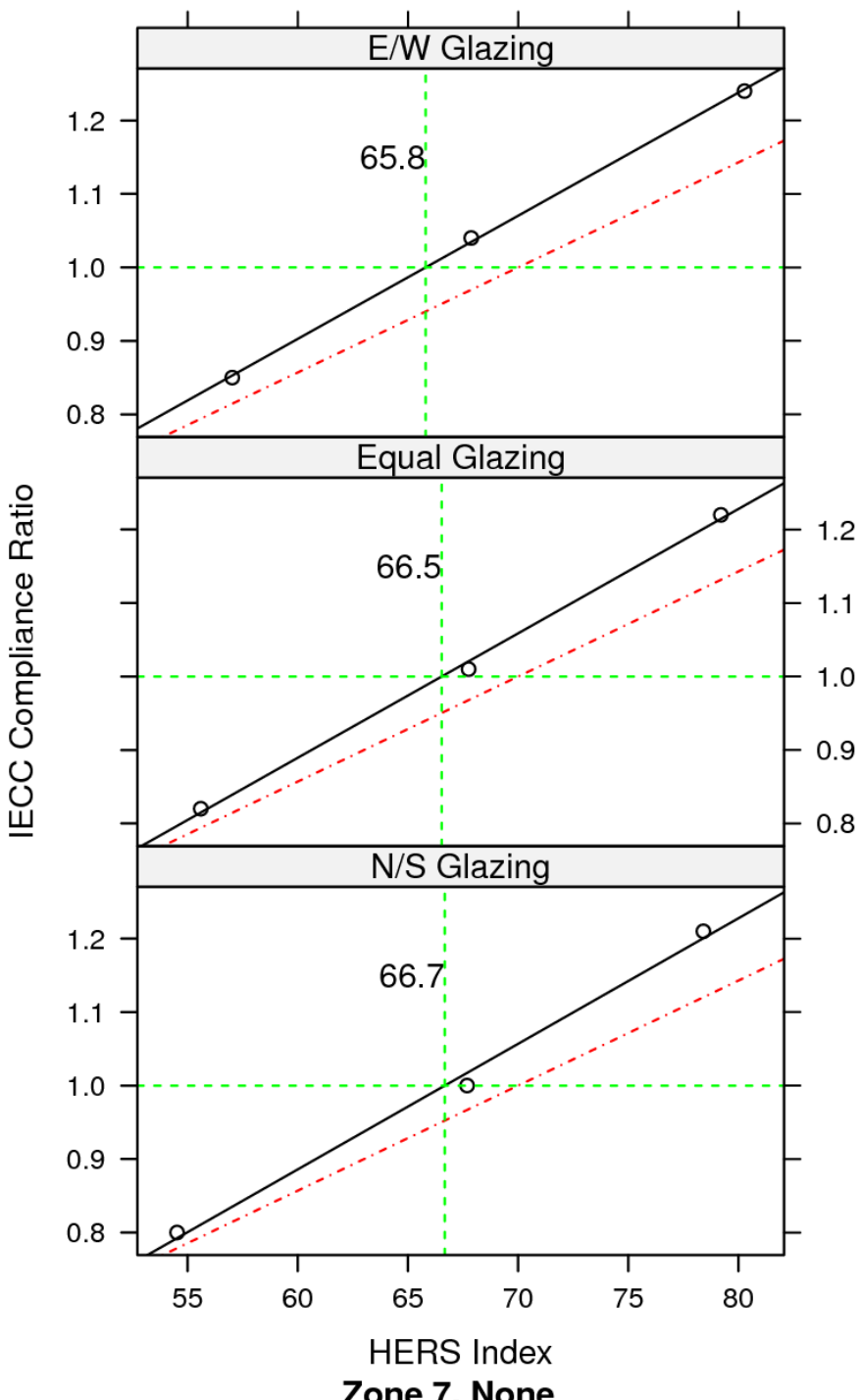

Number of Stories

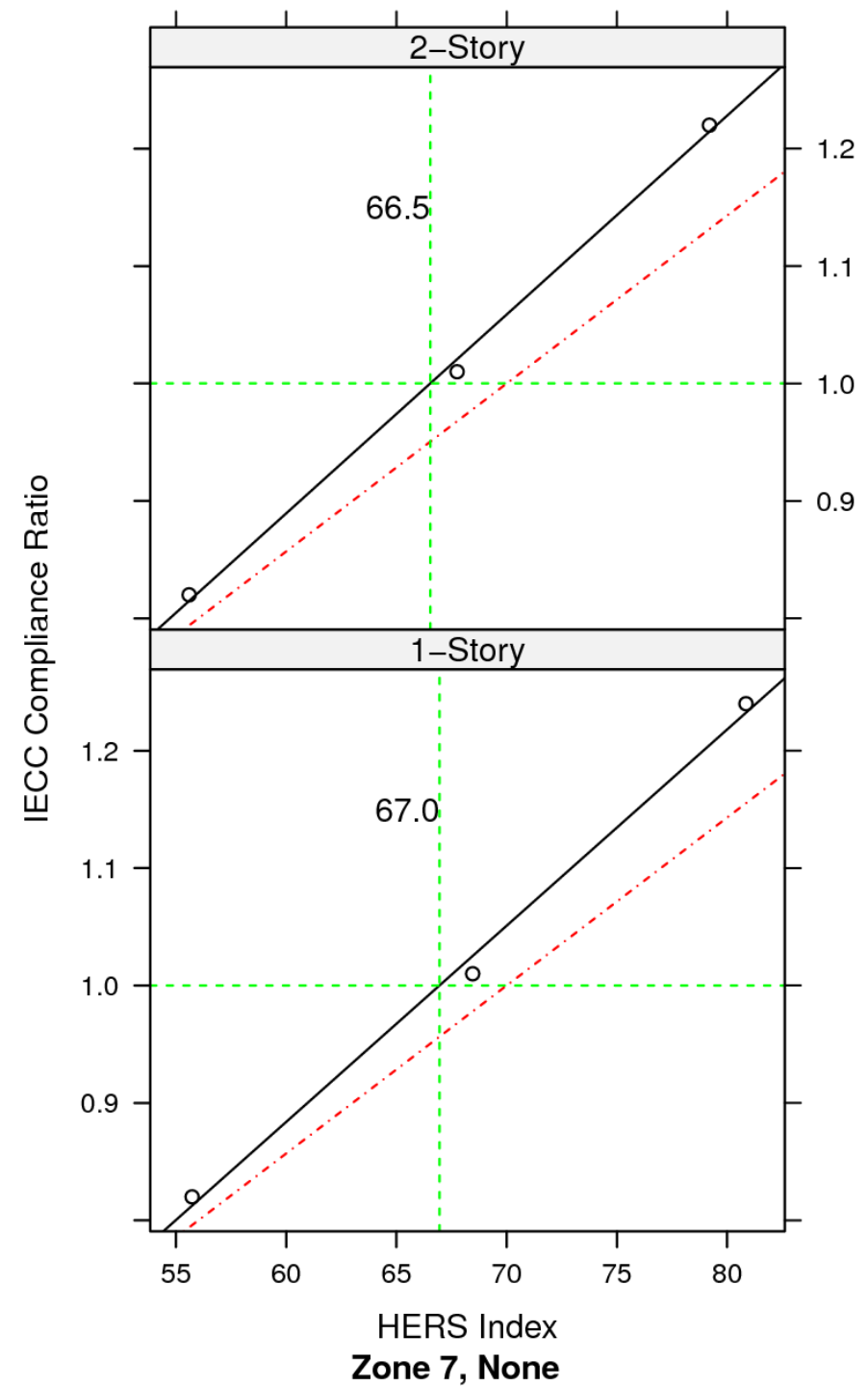

Figure A.14. Corresponding HERS Indexes for Climate Zone 7 (contd) 


\section{Heat Pump Efficiency}

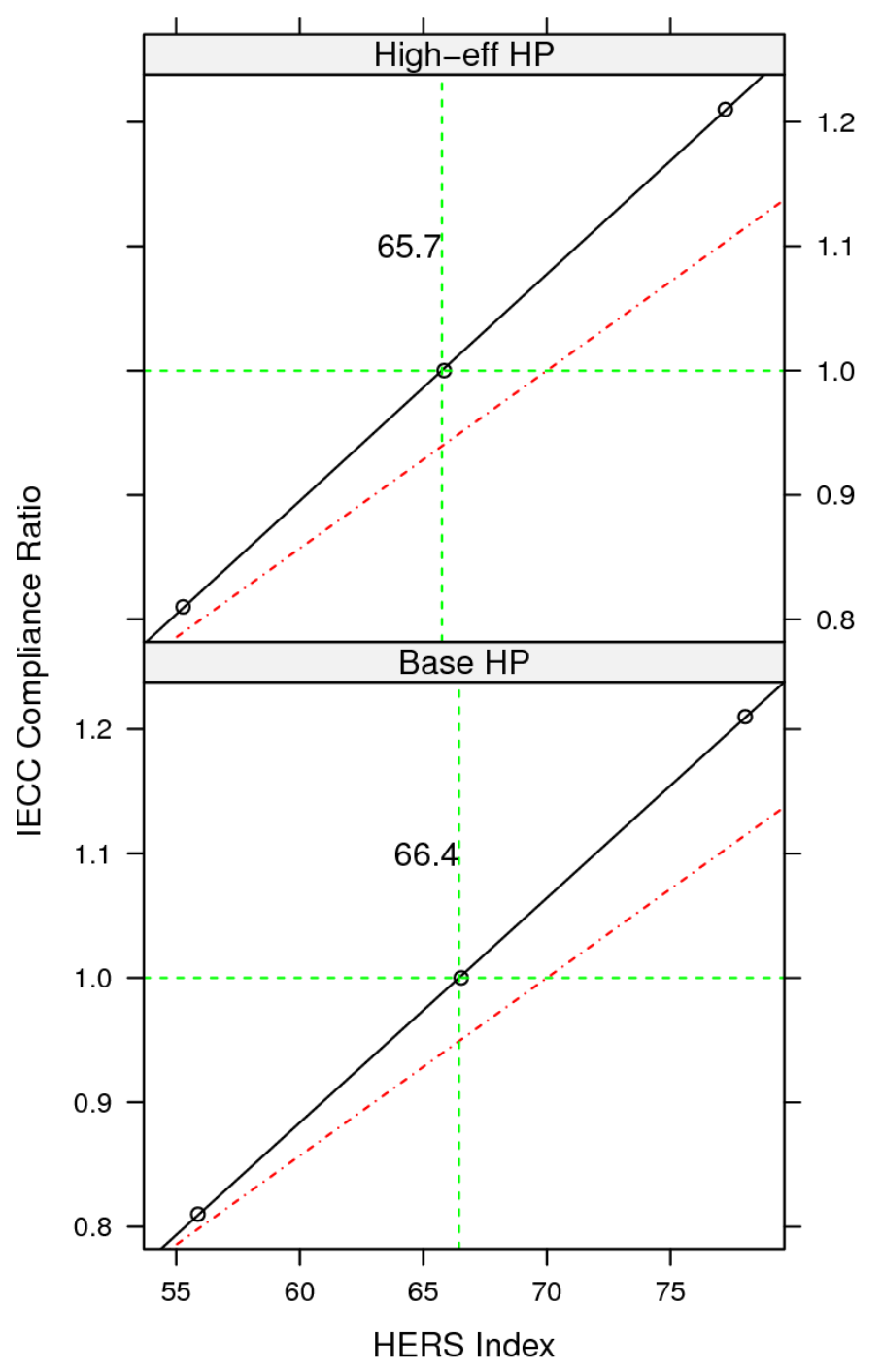

Zone 8, None
Gas Furnace \& AC Efficiency

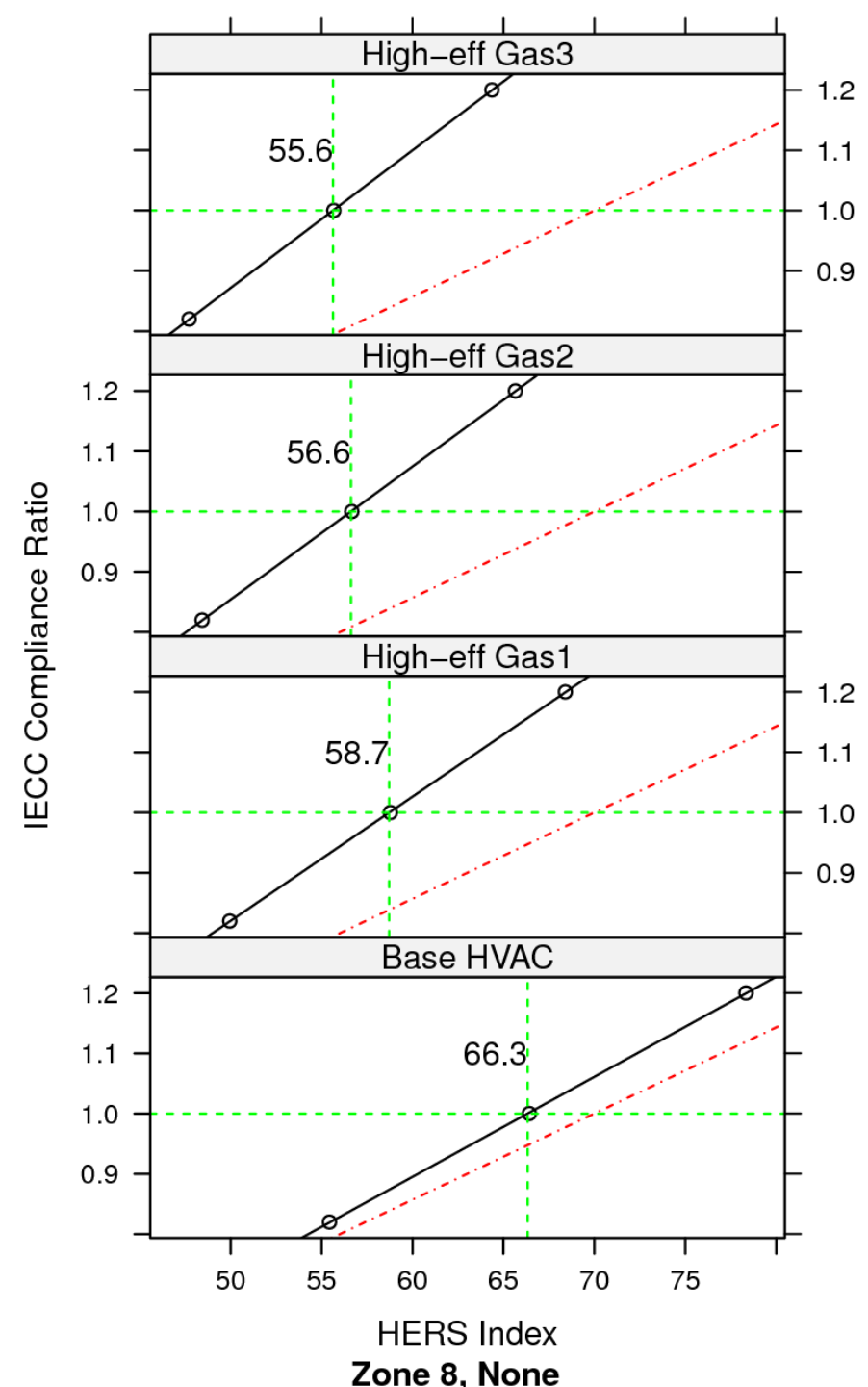

Figure A.15. Corresponding HERS Indexes for Climate Zone 8 
Window-Floor Ratio

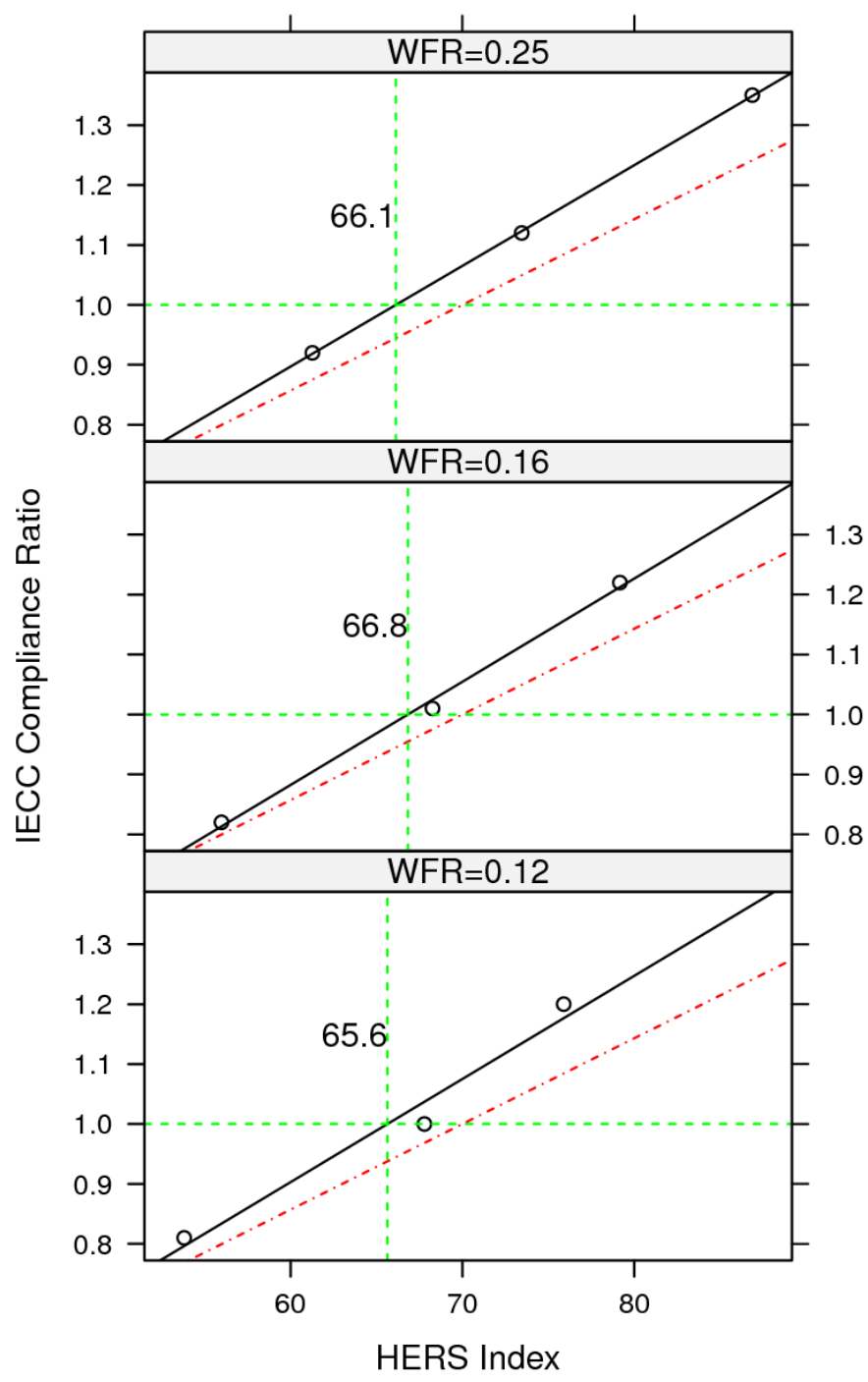

Zone 8, None

\section{Conditioned Floor Area}

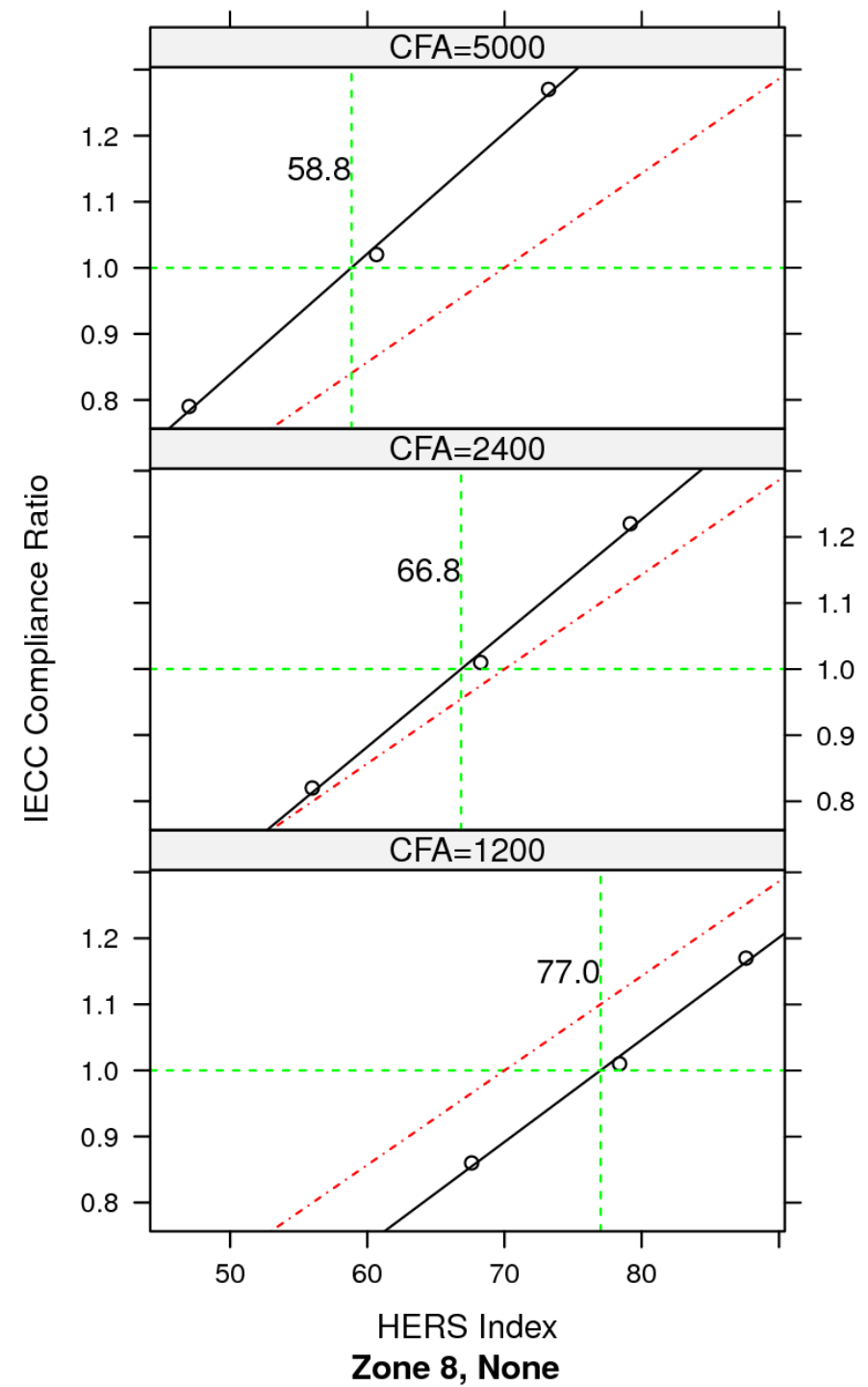

Figure A.15. Corresponding HERS Indexes for Climate Zone 8 (contd) 
Foundation

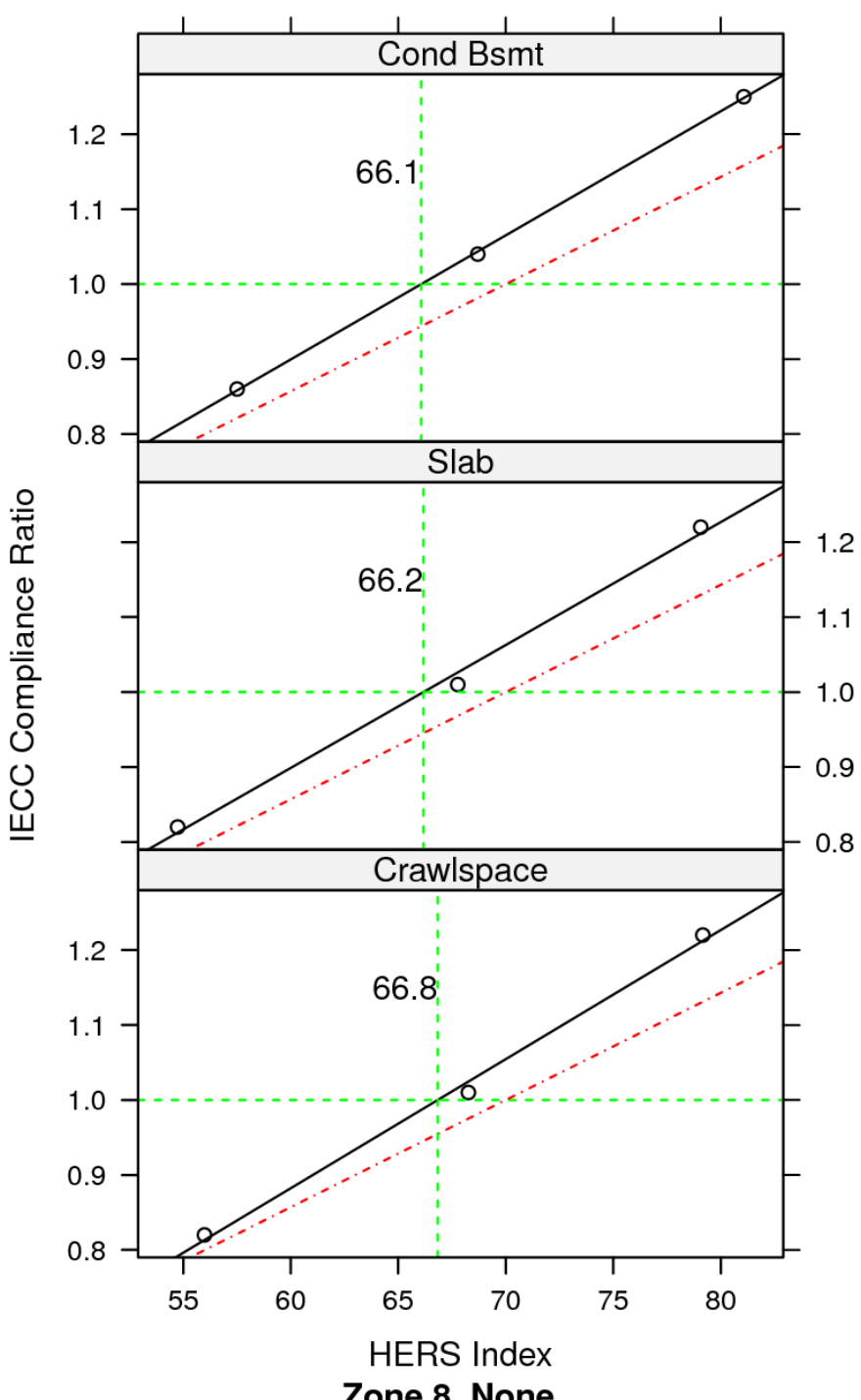

Appliances

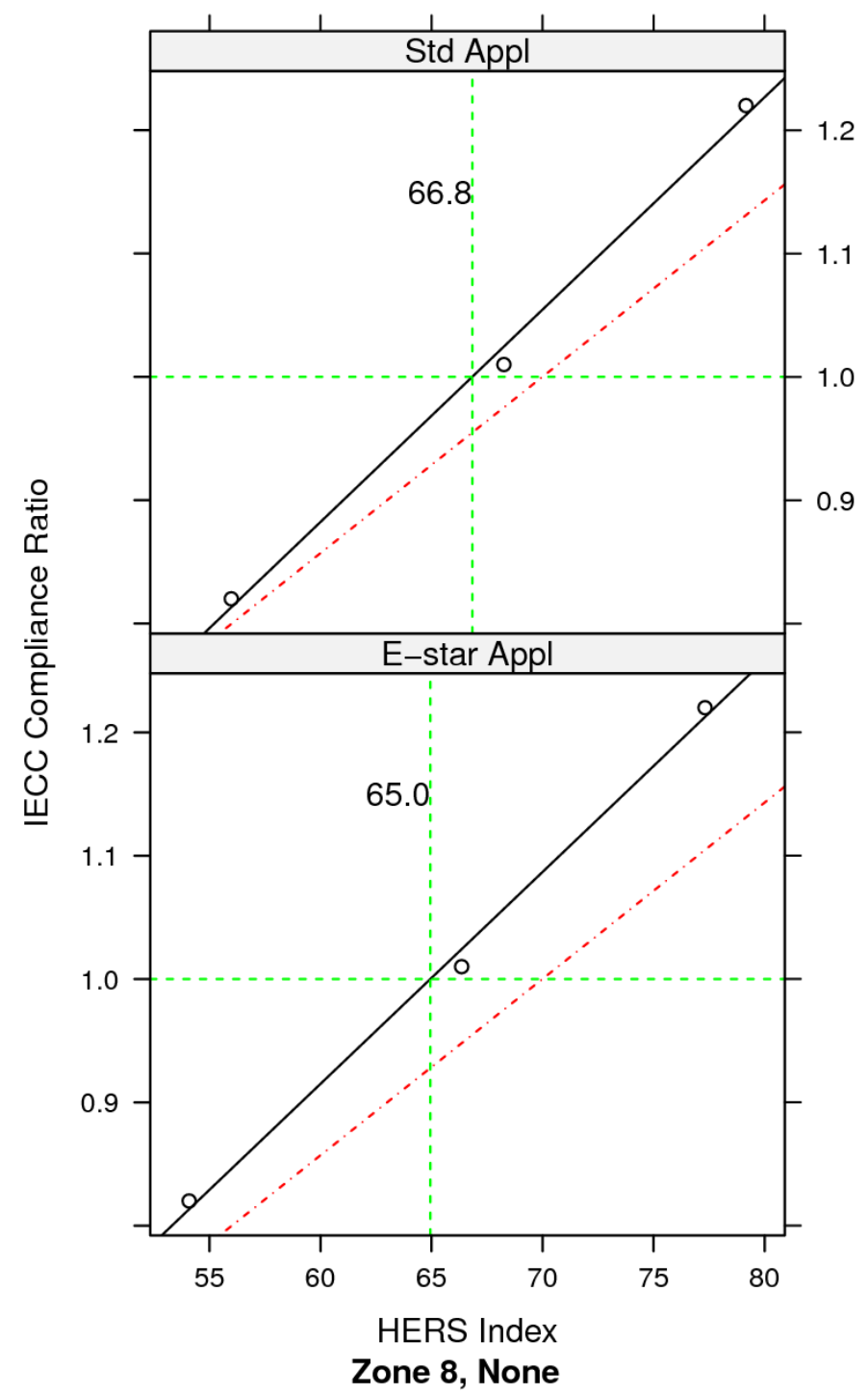

Figure A.15. Corresponding HERS Indexes for Climate Zone 8 (contd) 


\section{Glazing Orientation}

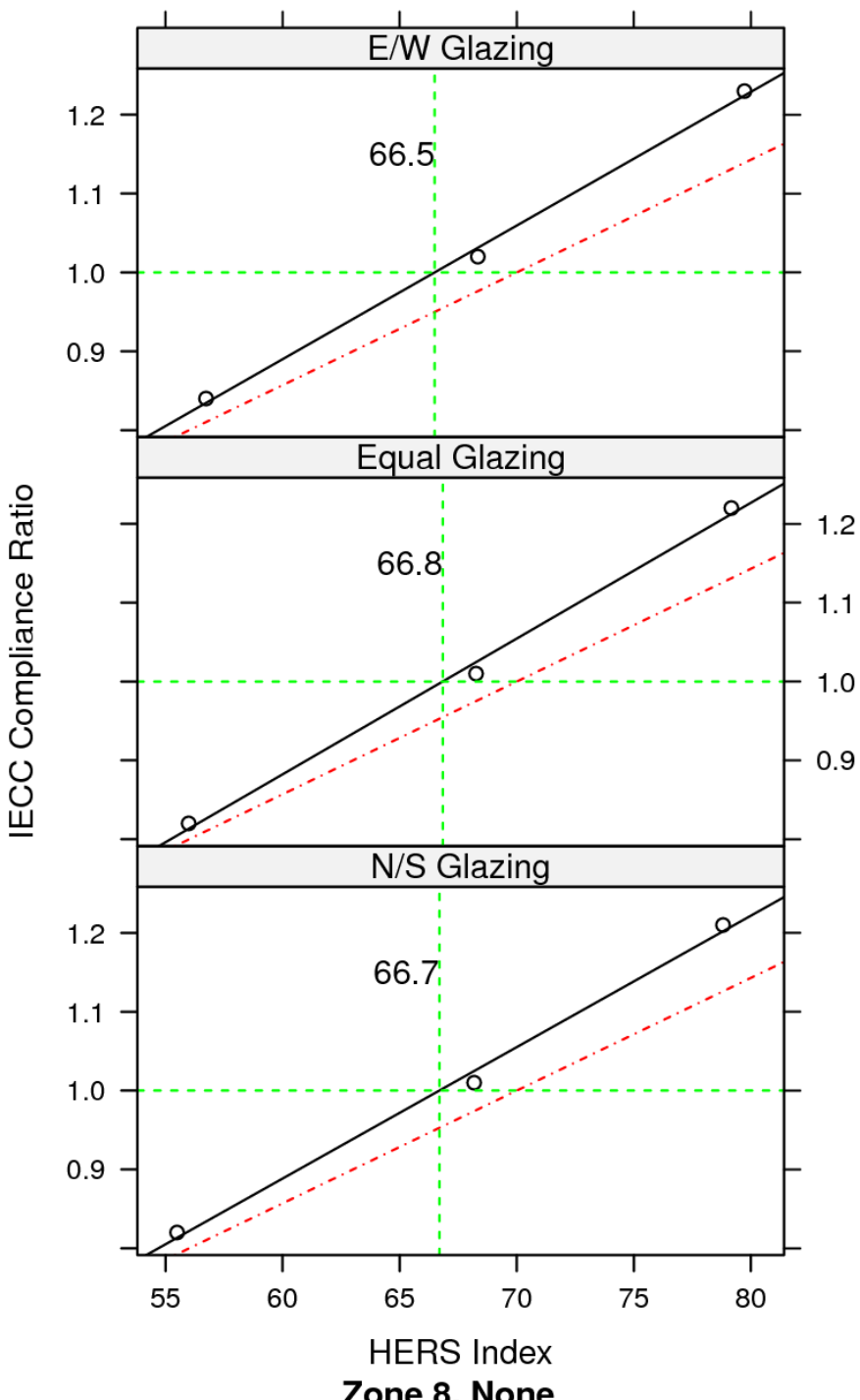

Number of Stories

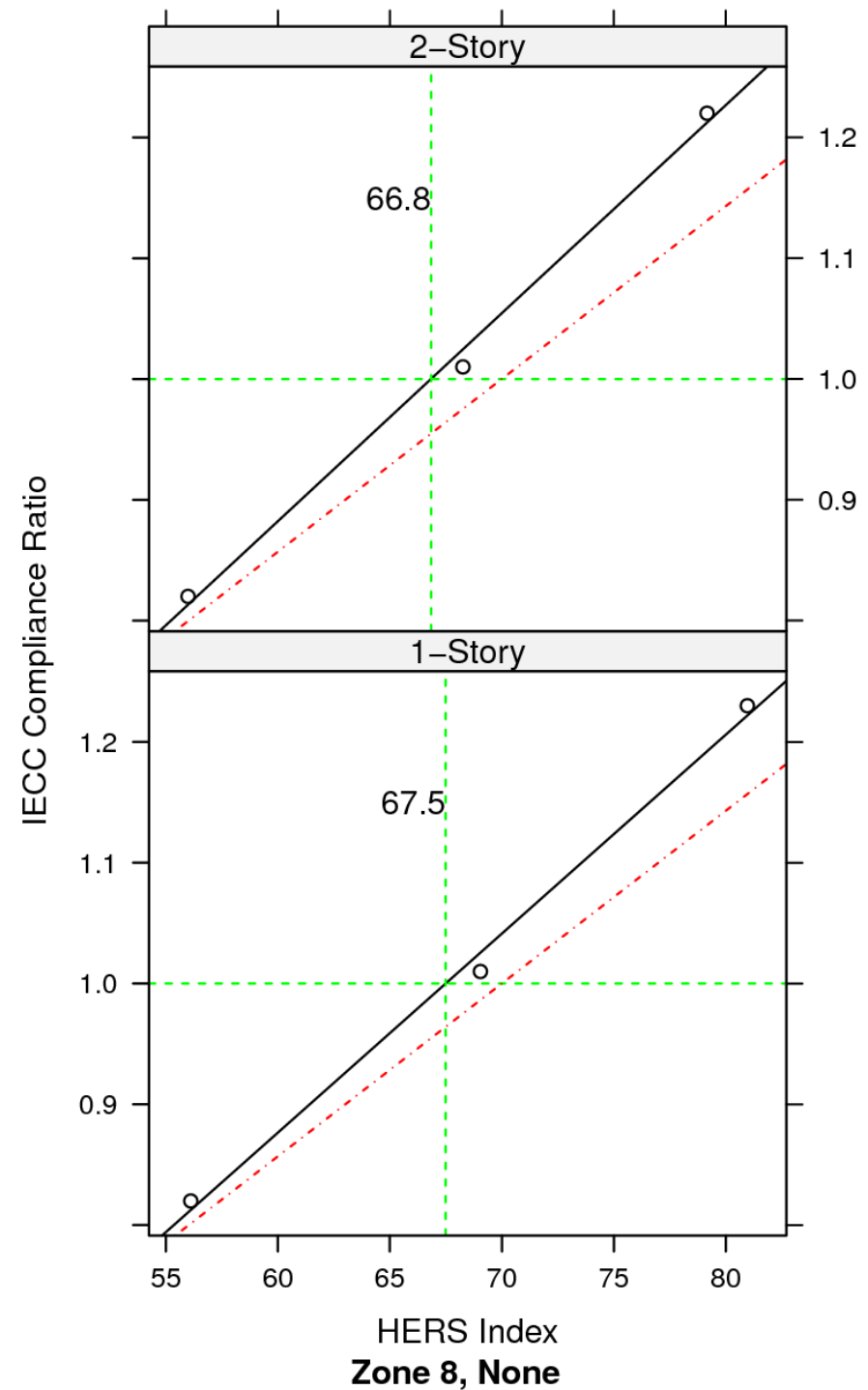

Figure A.15. Corresponding HERS Indexes for Climate Zone 8 (contd) 



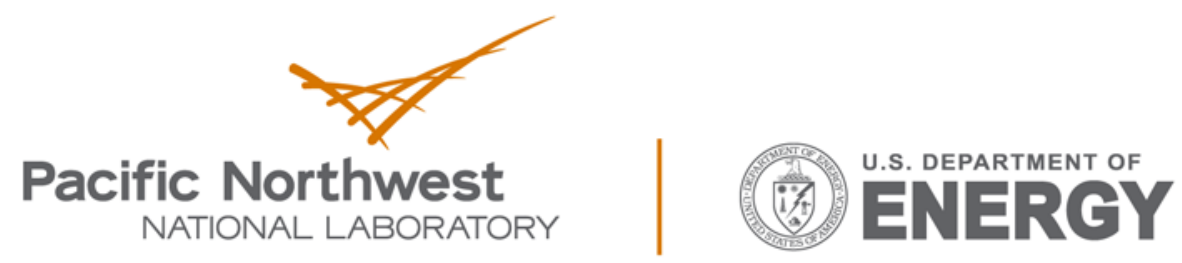

Proudly Operated by Battelle Since 1965

902 Battelle Boulevard

P.O. Box 999

Richland, WA 99352

1-888-375-PNNL (7665)

www.pnnl.gov 